Tiago Henrique Martins

\title{
CONVERSÃO DE COMPOSTOS NITROGENADOS EM REATORES BIOLÓGICOS: OPERAÇÃO, CARACTERIZAÇÃO MICROBIOLÓGICA E FILOGENÉTICA
}

\author{
Tese apresentada à Escola de Engenharia \\ de São Carlos da Universidade de São \\ Paulo, como parte dos requisitos para \\ obtenção do Título de Doutor em \\ Hidráulica e Saneamento.
}

Orientadora: Profa. Dra. Maria Bernadete Amâncio Varesche 
AUTORIZO A REPRODUÇÃO E DIVULGAÇÃO TOTAL OU PARCIAL DESTE TRABALHO, POR QUALQUER MEIO CONVENCIONAL OU ELETRÔNICO, PARA FINS DE ESTUDO E PESQUISA, DESDE QUE CITADA A FONTE.

Ficha catalográfica preparada pela Seção de Tratamento da Informação do Serviço de Biblioteca - EESC/USP

Martins, Tiago Henrique
M386c Conversão de compostos nitrogenados em reatores biológicos : operação, caracterização microbiológica e filogenética / Tiago Henrique Martins ; orientadora Maria Bernadete Amâncio Varesche. -- São Carlos, 2010.

Tese (Doutorado-Programa de Pós-Graduação e Área de Concentração em Hidráulica e Saneamento) -- Escola de Engenharia de São Carlos da Universidade de São Paulo, 2010 .

1. Nitrificação. 2. Reatores bioquímicos. 3. Anammox. 4. Reator operado em batelada. 5. Reator de leito fixo. 6. PEBD. 7. Brocadia sp. 8. Atividade anammox específica. I. Título. 
FOLHA DE JULGAMENTO

Candidato(a): Bacharel TIAGO HENRIQUE MARTINS

Tese defendida e julgada em 27/08/2010 perante a Comissão Julgadora:

Maresche aprovado

Prof ${ }^{a}$. Dr ${ }^{\mathrm{a}}$. MARIA BERNADETE AMÂNCIO VARESCHE SILVA - (Orientadora) (Escola de Engenharia de S申o Carlos/USP)

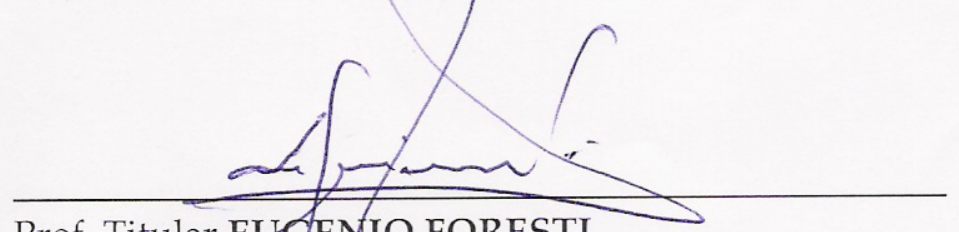

Prof. Titular EUGENIO FORESTI (Escola de Engerdharia de São Carlos/USP)

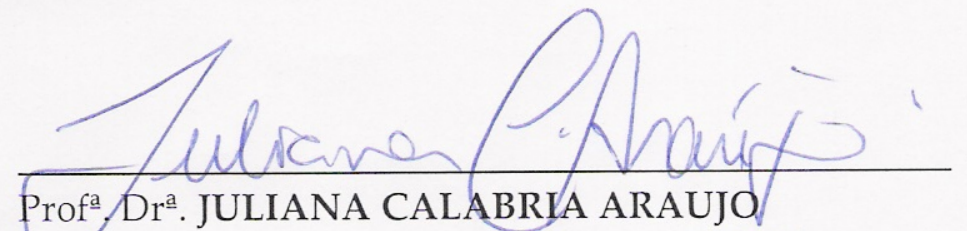

(Universidade Federal de Minas Gerais/UFMG)
APROVADO

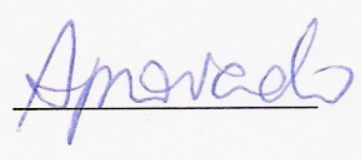

Aprovado

Prof. Dr.HUGO MOREIRA SOARES

(Universidade Federal de Santa Catarina/UFSC)

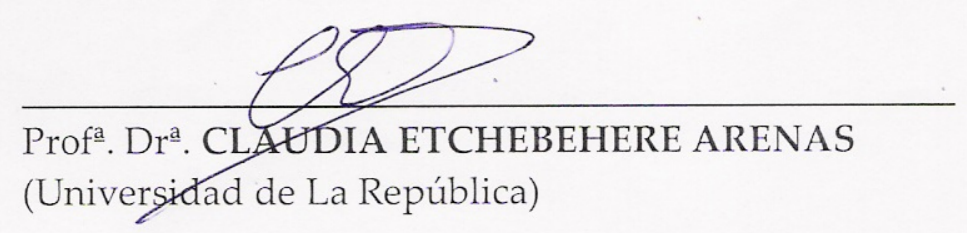

APROBADO

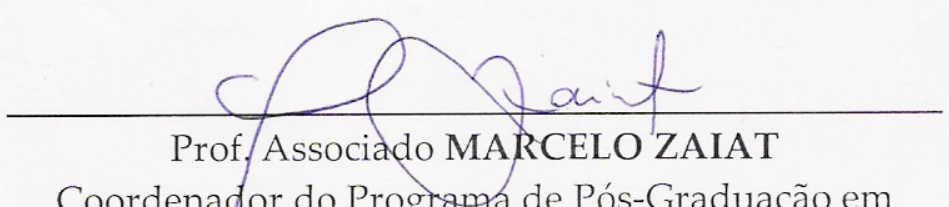

Coordenador do Programa de Pós-Graduação em Engenharia Hidráulica e Saneamento

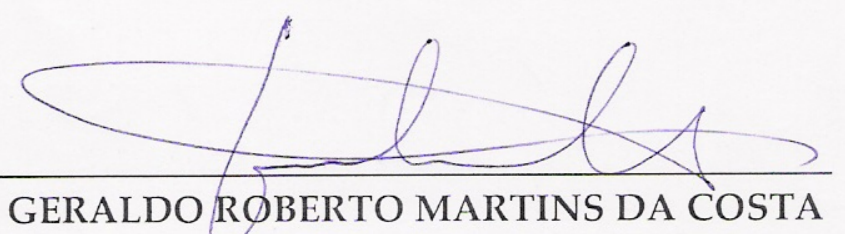

Prof. Titular GERALDO ROBERTO MARTINS DA COSTA
Presidente da Comissão da Pós-Graduação da EESC 
Dedico este trabalho à minha querida esposa Lis e à minha filha querida Sofia. A luz de vocês sempre me guiam e iluminam. Amo vocês! 


\section{AGRADECIMENTOS}

A fase dos agradecimentos de uma tese são um grande momento de reflexão e sentimento de realização pessoal. Durante todo o doutorado foram muitos momentos de felicidade e angústia, e neste momento... VALEU MUITO!!!

Agradeço minha esposa e minha filha por todo amor e compreensão durante o doutorado.

Agradeço a professora Bernadete pela orientação e apoio durante a pesquisa.

Ao professor Marcelo Zaiat e ao Dr. Arnaldo Sarti pelas valiosas considerações no exame de qualificação. Agradeço também ao professor Eugênio Foresti pelas, sempre valiosas, discussões.

Ao engenheiro Moacir Araújo Júnior da Ajinomoto por ceder o lodo utilizado como inóculo.

À Dr. Eloisa Pozzi (a Elô), à Dani e à Renata pelas fundamentais discussões em Biologia Molecular. E à Maria Ângela (a Janja) pelas divagações no mundo da química.

Ao meu amigo Betão grande companheiro de laboratório e de vida.

À aluna de IC Érica Sumita pela ajuda na operação dos reatores e ensaios de atividade.

Agradeço ao professor Edson Luis Silva (o Tininho) pela ajuda nos cálculos e discussão cinética.

Dagoberto e Tiago Paladino, a dupla do LAS, valeu.

Ao trio da desnitrificação autotrófica e companheiros de FIA Pantoja, Theo e Bruna, obrigado.

Às microbiologistas Sandra, Carol, Isabel e Regiane e à engenheira Lorena pelo apoio e amizade. E à Julia pela manutenção dos reatores durante o AD latino americano.

Aos funcionários de departamento em especial à Sá, Pavi, Rose e André.

Ao $\mathrm{CNPq}$ pela bolsa de estudos fundamental para este trabalho, e à FAPESP pelos recursos da pesquisa através do projeto temático.

Ao meu pai André e minha mãe Angélica pelo apoio durante toda vida. E meu irmão Lucas que instalou o programa ARB para mim. 


\section{RESUMO}

MARTINS, T.H. (2010). Conversão de compostos nitrogenados em reatores biológicos: operação, caracterização microbiológica e filogenética. 115p. Tese (Doutorado) Escola de Engenharia de São Carlos, Universidade de São Paulo, São Carlos, 2010 .

Esta pesquisa objetivou enriquecer biomassa capaz de realizar a oxidação anaeróbia do amônio (anammox) utilizando inóculo proveniente de reator nitrificante-desnitrificante, com a finalidade de estabelecer biofilme nitrificante-anammox em reator de leito fixo. $\mathrm{O}$ enriquecimento foi realizado em reator operado em bateladas sequenciais (RBS), com volume útil de 5L e tempo de ciclo, inicialmente, de 56h, e depois, sem tempo predeterminado (estratégias I e II). Após 89 dias de operação, 27,2 mg de $\mathrm{N}^{-\mathrm{NO}_{2}}{ }^{-} / \mathrm{L}$ e 32,1 mg de $\mathrm{N}_{-\mathrm{NH}_{4}}{ }^{+} / \mathrm{L}$ foram consumidos concomitantemente. A estratégia III consistiu de batelada alimentada com ciclos de sete dias com afluente contendo $210 \mathrm{mg}$ de cada composto nitrogenado. Na última estratégia (IV) a operação foi com ciclos de $24 \mathrm{~h}$. Nessa etapa, a carga nitrogenada aplicada (CNA) foi aumentada de $155 \mathrm{~g}$ de $\mathrm{N}\left(\mathrm{N}_{-} \mathrm{NO}_{2}^{-} \mathrm{N}-\right.$ $\left.\mathrm{NH}_{4}{ }^{+}\right) / \mathrm{m}^{3}$ dia para $1.405,7 \mathrm{~g}$ de $\mathrm{N} / \mathrm{m}^{3}$ dia com eficiências de conversão de nitrogênio de $91,7 \%$ e $98,0 \%$, respectivamente. Essa biomassa foi inoculada em reator de leito fixo ascendente (RLF) visando estabelecimento da biomassa anammox em meio suporte (PEBD). Sob tais condições foi obtido eficiência de conversão de nitrogênio de 97,6\% e carga nitrogenada removida média de 598,5 $\pm 22,5 \mathrm{~g} \mathrm{~N} / \mathrm{m}^{3}$ dia. Após estabelecimento de biomassa anammox, foi adicionado lodo ativado da indústria Volkswagen (São Carlos-SP) para formação de biofilme nitrificante-anammox. Nessa fase, a remoção de nitrogênio foi de $19,2 \%$ para CNA de $112,2 \mathrm{~g} \mathrm{~N} / \mathrm{m}^{3}$ dia. A atividade anammox específica máxima foi $33,5 \mathrm{mgN} \mathrm{NH}_{4}{ }^{+} / \mathrm{g} \mathrm{SSV}$ h com a biomassa submetida à 50rpm. Paralelamente ao processo de enriquecimento, foi verificada a influência de micronutrientes em condições nitrificantes em três quimiostatos, nas seguintes condições: Q1 alimentado com meio contendo solução de micronutrientes completa, Q2 alimentado sem solução de micronutrientes e Q3 alimentado com solução de micronutrientes sem o elemento Boro (quimiostato experimental). Nas três condições a estabilidade foi atingida com 11 dias de operação com conversão média de nitrogênio amoniacal de $99 \pm 1,5 \%, 94,6 \pm 6,3 \%$ e 93,3

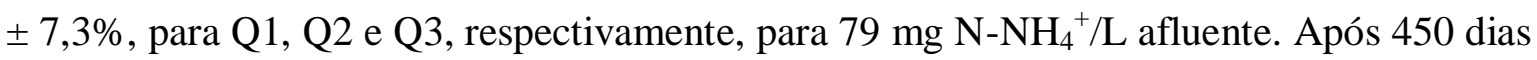


de operação do RBS foi constatado semelhança do clones com Brocadia anammoxidans, Planctomycetes, Proteobacteria, Chlorobi, Nitrospira, filo Chloroflexi e ao filo candidato OP 11. A composição microbiana encontrada no RLF com 139 dias de operação (final da fase anammox) foi de $48 \%$ dos clones relacionados à B. anammoxidans, $4 \%$ relacionados à Planctomycetes não cultivados, $12 \%$ relacionados à Proteobacteria, $8 \%$ relacionados à Chlorobi, 24\% relacionados à Nitrospira, 4\% relacionados ao filo Chloroflexi. Pode-se concluir que a biomassa aderida em PEBD selecionou positivamente microrganismos anammox e Nitrospira e negativamente aos filamentos relacionados ao filo Chloroflexi.

Palavras-chave: Nitrificação; anammox; reator operado em batelada; reator de leito fixo; PEBD; Brocadia sp.; atividade anammox específica. 


\begin{abstract}
MARTINS, T.H. (2010). Nitrogen compounds conversion in biological reactors: operation, microbiological and phylogenetic characterization. 115p. Thesis. Escola de Engenharia de São Carlos, Universidade de São Paulo, São Carlos, 2010.

This research aimed to enhance biomass capable of performing anaerobic ammonia oxidation (anammox) using inoculum from nitrifying-denitrifying reactor, with the goal of establishing nitrifying-anammox biofilm in fixed bed reactor. The enrichment was performed in sequencing batch reactor (SBR), with a volume of $5 \mathrm{~L}$ and cycle time, initially, 56h, and then, without pre-set time (strategies I and II). After 89 operation days, $27.2 \mathrm{mg} \mathrm{N}-\mathrm{NO}_{2}{ }^{-} / \mathrm{L}$ and $32.1 \mathrm{mg} \mathrm{N}-\mathrm{NH}_{4}{ }^{+} / \mathrm{L}$ were consumed concomitantly. The strategy consisted of fed batch III with seven days cycles with influent containing $210 \mathrm{mg}$ of each nitrogen compound. The last strategy (IV) was with $24 \mathrm{~h} /$ cycle. At this strategy, the nitrogen applied load (NAL) was increased from $155 \mathrm{~N}\left({\mathrm{~N}-\mathrm{NO}_{2}}^{-}+\mathrm{N}^{-} \mathrm{NH}_{4}{ }^{+}\right) / \mathrm{m}^{3}$ to 1405.7 $\mathrm{g} \mathrm{N} / \mathrm{m}^{3}$ day with conversion efficiencies of $91.7 \%$ nitrogen and $98.0 \%$, respectively. This biomass was inoculated into fixed bed reactor up (FBR) in order to establish the anammox biomass in support medium (LDPE). Under such conditions was obtained nitrogen conversion efficiency of $97.6 \%$ and nitrogen load removed an average of $598.5 \pm 22.5 \mathrm{~g}$ $\mathrm{N} / \mathrm{m}^{3}$ day. After establishment of anammox biomass it was added activated sludge Volkswagen industry (São Carlos-SP) - for nitrifying-anammox biofilm. At that stage the removal of nitrogen was $19.2 \%$ to $112.2 \mathrm{~g} \mathrm{CNA} \mathrm{N} / \mathrm{m}^{3}$ day. Simultaneously to enrichment process, was verified the influence of micronutrients in nitrifying conditions in three chemostats, as follows: Q1 fed with medium containing micronutrients solution complete feeds without Q2 and Q3 micronutrients solution fed micronutrients solution without the element Boron (chemostat experiment). In the three conditions stability was achieved with 11 days of operation with average conversion of ammonia nitrogen of $99 \pm 1.5 \%, 94.6 \pm$ $6.3 \%$ and $93.3 \pm 7.3 \%$ for Q1, Q2 and Q3 respectively for $79 \mathrm{mg} \mathrm{N}-\mathrm{NH}_{4}{ }^{+} / \mathrm{L}$. After 450 days of operation of the RBS was found similarity of clones with Brocadia anammoxidans, Planctomycetes, Proteobacteria, Chlorobi, Nitrospira, Chloroflexi phyla and candidate phylum OP 11. The microbial composition found in the FBR with 139 days of operation (end of anammox phase) was $48 \%$ of clones related to B. anammoxidans, $4 \%$ related to uncultured Planctomycetes, Proteobacteria related to 12\%, $8 \%$ related to Chlorobi, $24 \%$
\end{abstract}


related to Nitrospira, $4 \%$ related to the phylum Chloroflexi. It can be concluded that biomass adhered to LDPE selected anammox microorganisms and Nitrospira positively, and negatively to the filaments related to the Chloroflexi phylum.

Keywords: Nitrification; anammox; sequencing batch reactor; fixed bed reactor; LDPE; Brocadia sp.; specific anammox activity 


\section{SUMÁRIO}

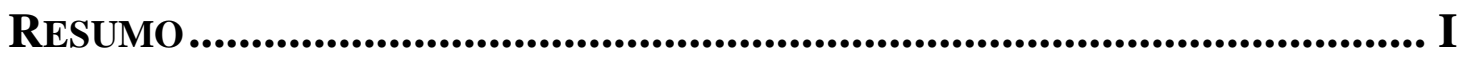

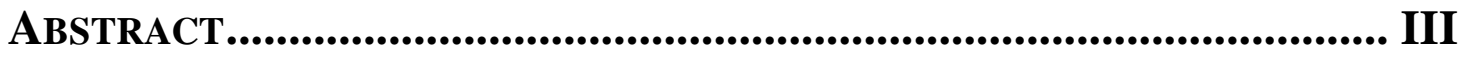

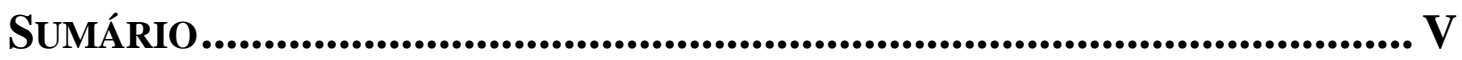

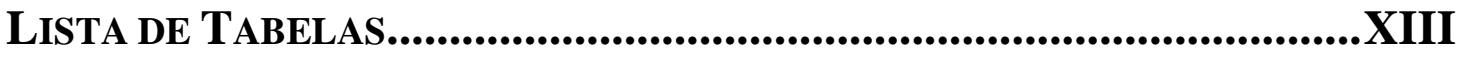

1 INTRODUÇÃO..............................................................................................1 1

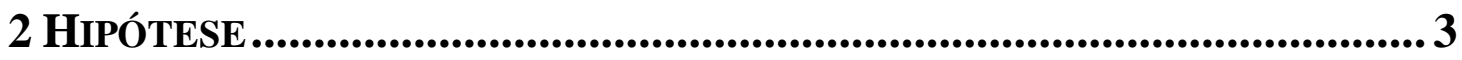

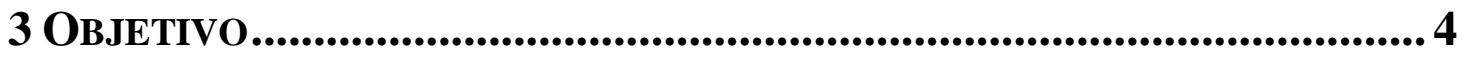

3.1 OBJETIVO GERAL ................................................................................................ 4

3.2 OBJETIVOS ESPECÍFICOS.................................................................................... 4

4 REVISÃo BIBLIOGRÁFICA ..........................................................5

4.1 NITRIFICAÇÃ $O$......................................................................................................... 5

4.2 PROCESSOS SHARON e CANON ………………………………………………... 8

4.4 ANAMMOX ................................................................................................................... 9

4.4.1 Taxonomia e Aspectos Fisiológicos ..........................................................................12

5 MATERIAL E MÉTOdos..................................................................... 18

5.1 PROCEDIMENTO EXPERIMENTAL ..................................................................18

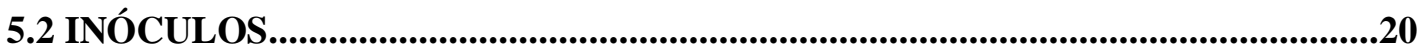

5.3 ENRIQUECIMENTO EM REATOR OPERADO EM BATELADA

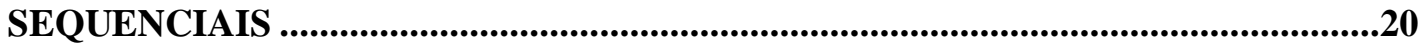

5.4 OPERAÇÃO DO REATOR DE LEITO FIXO .......................................................23

5.5 ENSAIOS FISIOLÓGICOS DE ATIVIDADE ANAMMOX ESPECÍFICA...........24 5.6 ENSAIO PARA VERIFICAÇÃO DA INFLUÊNCIA DE MICRONUTRIENTES NA NITRIFICAÇÃO ...............................................................25

5.7 ANÁLISES FÍSICO-QUÍMICAS...............................................................................27

5.6 ANÁLISE DE BIOLOGIA MOLECULAR................................................................27

5.7 EXAMES MICROSCÓPICOS..................................................................................28

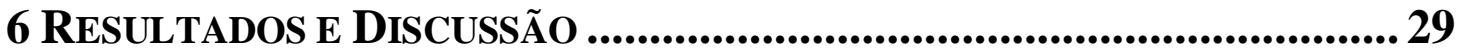

6.1 OPERAÇÃO DOS QUIMIOSTATOS PARA VERIFICAR A INFLUÊNCIA 
DE MICRONUTRIENTES NA NITRIFICAÇÃO

6.2 REATOR OPERADO EM BATELADAS SEQUENCIAIS....................................34

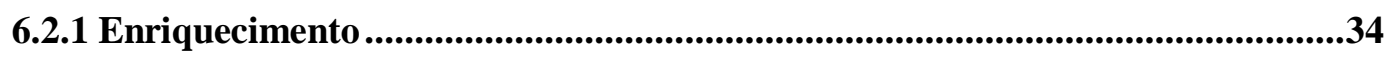

6.2.2 Operação do RBS com Ciclos de 24 Horas.......................................................39

6.2.3 Perfis de Consumo de Nitrogênio no RBS ........................................................45

6.3 ENSAIOS FISIOLÓGICOS DE ATIVIDADE ANAMMOX ESPECÍFICA...........49

6.3.1 Influência da Frequência de Agitação .............................................................49

6.3.2 Ensaios Fisiológicos em Reator de Batelada Descontínuo sem Agitação ...........55

6.3.2.1 Variação da Concentração dos Compostos Nitrogenados.........56

6.3.2.2 Influência da Temperatura........................................................ 62

6.4 OPERAÇÃO DO REATOR DE LEITO FIXO ...............................................69

6.5 ANÁLISES MICROSCÓPICAS E DE BIOLOGIA MOLECULAR .......................78

6.5.1 Análises Microscópicas .....................................................................................78

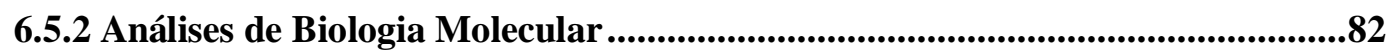

6.5.2.1 Caracterização Filogenética da Biomassa Presente no RBS com

170 dias de operação ..........................................................................82

6.5.2.2 Caracterização Filogenética da Biomassa Presente no RBS com

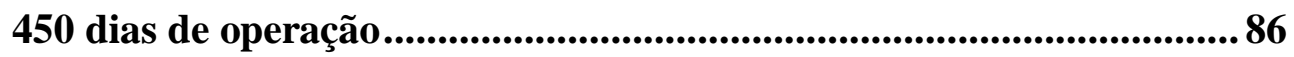

6.5.2.3 Caracterização Filogenética da Biomassa presente no RLF com 139 dias de operação................................................................................93

6.5.2.4 Análise Filogenética Comparativa dos Reatores .......................97

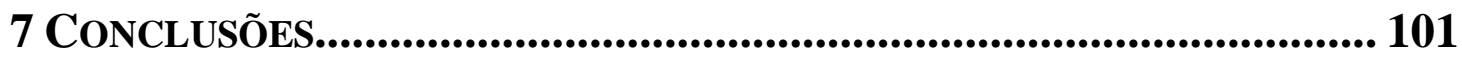

8 REFERÊNCIAS BIBLIOGRÁFICAS...................................................... 103 


\section{LISTA DE FigURAS}

Figura 1. Arvore filogenética do filo Planctomycete baseada na sequência do gene do RNA ribossomal 16S. A barra de escala representa 10\% de divergência filogenética.

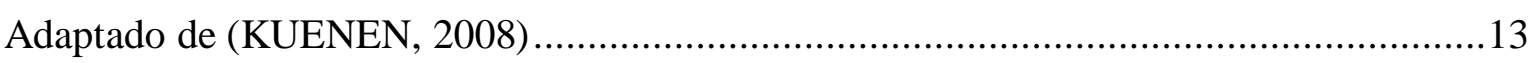

Figura 2. Fluxograma das etapas experimentais ...........................................19

Figura 3. Fluxograma dos ensaios para verificação da influência de micronutrientes na nitrificação

Figura 4. Esquema do reator operado em bateladas sequenciais .........................21

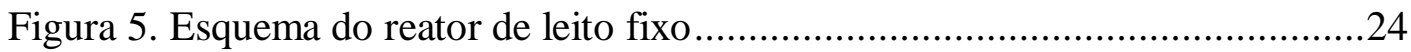

Figura 6. Esquema do quimiostato utilizado nos ensaios para verificação da influência de micronutrientes na nitrificação 26

Figura 7. Variação temporal da concentração das formas nitrogenadas em Q1 ......30

Figura 8. Variação temporal da concentração das formas nitrogenadas em Q2 ......30

Figura 9. Variação temporal da concentração das formas nitrogenadas em Q3 ......31

Figura 10. Variação temporal da concentração de amônio nos quimiostatos nitrificantes 32

Figura 11. Variação dos compostos nitrogenados e $\mathrm{pH}$ durante a estratégia I de enriquecimento 35

Figura 12. Variação dos compostos nitrogenados durante a estratégia II de enriquecimento 37

Figura 13. Variação dos compostos nitrogenados durante a estratégia III de enriquecimento 38

Figura 14. Variação da concentração de biomassa (SSV) no reator 38

Figura 15. Variação dos compostos nitrogenados e pH durante a estratégia IV .....40

Figura 16. Biomassa granulada presente no RBS com 294 de operação 41

Figura 17. Efluente do RBS avermelhado do $344^{\circ}$ dia de operação 42

Figura 18. Microscopia ótica de contraste de fase do efluente do $344^{\circ}$ dia. Tamanho 
da barra: $5 \mu \mathrm{m}$

Figura 19. Eficiência de remoção de nitrogênio (vermelho) e eficiência de conversão de nitrogênio (azul) durante a estratégia IV

Figura 20. Relações estequiométricas de nitrito removido/amônio removido e nitrato produzido/amônio removido durante a estratégia IV

Figura 21. Perfil temporal dos compostos nitrogenados no RBS (Etapa 1), concentração: 77,4 mg N-NH${ }_{4}^{+} / \mathrm{L}$ e 82,9 mg N-NO${ }_{2}^{-} / \mathrm{L}$ 46

Figura 22. Perfil temporal dos compostos nitrogenados no RBS (Etapa 2), concentração afluente: $143,4 \mathrm{mg} \mathrm{N}-\mathrm{NH}_{4}{ }^{+} / \mathrm{L}$ e $184,5 \mathrm{mg} \mathrm{N}-\mathrm{NO}_{2}{ }^{-} / \mathrm{L}$

Figura 23. Perfil temporal dos compostos nitrogenados no RBS (Etapa 4), concentração afluente: $233,7 \mathrm{mg} \mathrm{N}-\mathrm{NH}_{4}{ }^{+} / \mathrm{L}$ e $290 \mathrm{mg} \mathrm{N}-\mathrm{NO}_{2}{ }^{-} / \mathrm{L}$

Figura 24. Perfil temporal dos compostos nitrogenados no RBS (Etapa 5), concentração afluente: $283 \mathrm{mg} \mathrm{N}-\mathrm{NH}_{4}{ }^{+} / \mathrm{L}$ e $323,5 \mathrm{mg} \mathrm{N}-\mathrm{NO}_{2}{ }^{-} / \mathrm{L}$ .48

Figura 25. Perfil temporal dos compostos nitrogenados no RBS (Etapa 6), concentração afluente: $348,8 \mathrm{mg} \mathrm{N}-\mathrm{NH}_{4}{ }^{+} / \mathrm{L}$ e $379,6 \mathrm{mg} \mathrm{N}-\mathrm{NO}_{2}{ }^{-} / \mathrm{L}$ 48

Figura 26. (a) Variação temporal de compostos nitrogenados no RBS submetido a 50 rpm; (b) Intervalo de ajuste dos parâmetros cinéticos, o eixo das ordenadas foi ajustado pela concentração de biomassa (SSV) .50

Figura 27. (a) Variação temporal de compostos nitrogenados no RBS submetido a 80 rpm; (b) Intervalo de ajuste dos parâmetros cinéticos, o eixo das ordenadas foi ajustado pela concentração de biomassa (SSV). .51

Figura 28. (a) Variação temporal de compostos nitrogenados no RBS submetido a $100 \mathrm{rpm}$; (b) Intervalo de ajuste dos parâmetros cinéticos, o eixo das ordenadas foi ajustado pela concentração de biomassa (SSV).

Figura 29. (a) Variação temporal de compostos nitrogenados no RBS submetido a $150 \mathrm{rpm}$; (b) Intervalo de ajuste dos parâmetros cinéticos, o eixo das ordenadas foi ajustado pela concentração de biomassa (SSV) .53

Figura 30. Variação dos parâmetros cinéticos $\mathrm{k}_{\mathrm{NH} 4+}(\mathrm{AAE}), \mathrm{k}_{\mathrm{NO} 2-} \mathrm{e} \mathrm{k}_{\mathrm{N}}$ total $\mathrm{em}$ função da agitação no RBS .55

Figura 31. Reatores em batelada descontínuos do ensaio de atividade anammox 
Figura 32. Variação temporal de consumo de amônio no reator em batelada, sem

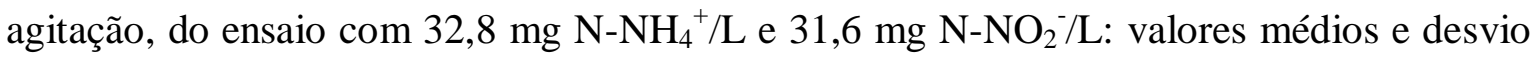
padrão.

Figura 33. Variação temporal de consumo de nitrito nos reatores em batelada, sem

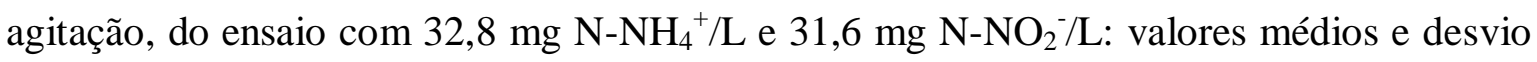
padrão

Figura 34. Intervalo de ajuste dos parâmetros cinéticos do ensaio com 33,8 mg N$\mathrm{NH}_{4}{ }^{+} / \mathrm{L}$ e $31,6 \mathrm{mg} \mathrm{N}-\mathrm{NO}_{2}{ }^{-} / \mathrm{L}$, o eixo das ordenadas foi ajustado pela concentração de biomassa (SSV)

Figura 35. Variação temporal de consumo de amônio no reator em batelada, sem agitação, do ensaio com $67 \mathrm{mg} \mathrm{N}-\mathrm{NH}_{4}{ }^{+} / \mathrm{L}$ e $73 \mathrm{mg} \mathrm{N}-\mathrm{NO}_{2}{ }^{-} / \mathrm{L}$ : valores médios e desvio padrão..... .58

Figura 36. Variação temporal de consumo de nitrito no reator em batelada, sem

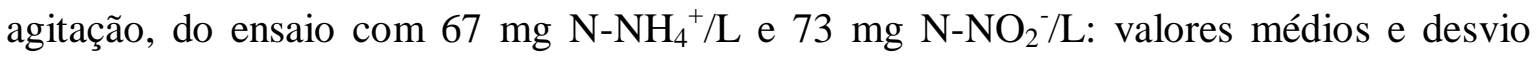
padrão. .58

Figura 37. Intervalo de ajuste dos parâmetros cinéticos do ensaio com $67 \mathrm{mg} \mathrm{N}$ $\mathrm{NH}_{4}{ }^{+} / \mathrm{L}$ e $73 \mathrm{mg} \mathrm{N}-\mathrm{NO}_{2}{ }^{-} / \mathrm{L}$, o eixo das ordenadas foi ajustado pela concentração de biomassa (SSV) .59

Figura 38. Variação temporal de consumo de amônio no reator em batelada, sem

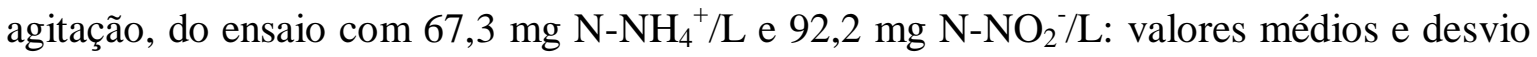
padrão

Figura 39. Variação temporal de consumo de nitrito no reator em batelada, sem

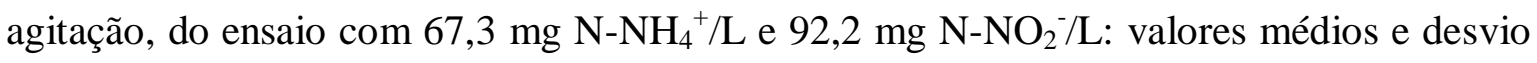
padrão.

Figura 40. Intervalo de ajuste dos parâmetros cinéticos do ensaio com 67,3 mg N$\mathrm{NH}_{4}{ }^{+} / \mathrm{L}$ e $92,2 \mathrm{mg} \mathrm{N}-\mathrm{NO}_{2}{ }^{-} / \mathrm{L}$, o eixo das ordenadas foi ajustado pela concentração de biomassa (SSV)

Figura 41. Variação dos parâmetros cinéticos $\mathrm{k}_{\mathrm{NH} 4+}(\mathrm{AAE}), \mathrm{k}_{\mathrm{NO} 2-} \mathrm{e} \mathrm{k}_{\mathrm{N}}$ total $\mathrm{em}$ função da concentração inicial e razão molar afluente 
Figura 42. Variação temporal de consumo de amônio em reator em batelada, sem agitação, submetidos a diferentes temperaturas: (a) $35^{\circ} \mathrm{C}$; (b) $30^{\circ} \mathrm{C}$; (c) $25^{\circ} \mathrm{C}$ e (d) $20^{\circ} \mathrm{C} \ldots 63$

Figura 43. Variação temporal de consumo de nitrito em reator em batelada, sem agitação, submetidos a diferentes temperaturas: (a) $35^{\circ} \mathrm{C}$; (b) $30^{\circ} \mathrm{C}$; (c) $25^{\circ} \mathrm{C}$ e (d) $20^{\circ} \mathrm{C} \ldots 64$

Figura 44. Intervalo de ajuste dos parâmetros cinéticos nos ensaios com diferentes temperaturas: (a) $35^{\circ} \mathrm{C}$; (b) $30^{\circ} \mathrm{C}$; (c) $25^{\circ} \mathrm{C}$ e (d) $20^{\circ} \mathrm{C}$. O eixo das ordenadas foi ajustado pela concentração de biomassa (SSV). .66

Figura 45. Comparação dos parâmetros cinéticos específicos em função da temperatura 67

Figura 46. Reator de Leito Fixo após a inoculação, detalhes do leito e entrada do reator

Figura 47. Variação temporal dos compostos nitrogenados e pH durante as etapas 1 a 4 de operação do Reator de Leito fixo 70

Figura 48. Reator de Leito Fixo no final de operação da etapa 4 (139 dias de operação): (a) entrada do RLF; (b) detalhe da biomassa anammox aderida na pedra porosa

Figura 49. Variação temporal dos compostos nitrogenados, oxigênio dissolvido e pH durante a etapa de nitrificação/anammox de operação do Reator de Leito Fixo 72

Figura 50. Variação temporal de compostos nitrogenados e pH durante as etapas 5 e 6 de operação do Reator de Leito fixo .73

Figura 51. Reator de Leito fixo com 251 dias de operação $\left(50^{\circ}\right.$ dia depois que retornou às condições anammox): (a) base do RLF; (b) detalhe do leito com bolhas de gás $\left(\mathrm{N}_{2}\right)$

Figura 52. Carga nitrogenada aplicada e removida durante toda operação do RLF 74

Figura 53. Relação estequiométrica de nitrito removido/amônio removido e nitrato produzido/amônio removido durante as etapas 1 a 6 do RLF .75

Figura 54. Microscopia de contraste de fase do inóculo utilizado no RBS: (a) Zooglea sp., (b) filamento semelhante à Beggiatoa sp. (seta); (c) bacilos, cocos, cocobacilos e filamentos; (d) bacilos e cocos em suspensão; (e) aglomerado de bacilos e cocos; diatomácea (seta); (f) aglomerado de bacilos e cocos, estreptococos e rizópodo 
semelhante à Arcella sp (seta)

Figura 55. Microscopia de contraste de fase da biomassa presente no RBS com 67 dias de operação: (a) cocos, (b) aglomerado de cocos semelhante às bactérias anammox, (c) filamento, (d) bacilos e cocos .80

Figura 56. Microscopia de contraste de fase da biomassa presente no RBS com 344 dias de operação: (a) filamentos e aglomerado de cocos semelhante às bactérias anammox , (b) aglomerado de filamentos, (c) cocos, (d) cocos e filamento, (e) aglomerado de cocos semelhante às bactérias anammox aderidos a filamentos e (f) cocos aderidos a filamentos

Figura 57. Microscopia de contraste de fase da biomassa presente no RLF com 139 dias de operação; (a) morfologias semelhantes às bactérias anammox, (b) cocos

Figura 58. Curvas de rarefação de amostras do RBS sequenciadas utilizando primers específicos a partir de análise utilizando DOTUR

Figura 59. Árvore filogenética baseada em fragmento do gene rRNA 16S das cinco UTOs comparadas com bactérias anammox (ordem Brocadiales). Thermotoga maritima foi utilizada como grupo-externo, a barra indica dez substituições de 100 nucleotídeos. Árvore construída pelo programa ARB com filtro LanemaskPH

Figura 60. Constituição das sequências (utilizando primers específicos) amostradas com 170 dias de operação do RBS

Figura 61. Curvas de rarefação de amostra do RBS sequenciadas utilizando primers universais a partir de análise utilizando DOTUR

Figura 62. Árvore filogenética baseada em fragmento do gene RNAr 16S das 19 UTOs a partir de sequências encontradas nas amostras do RBS. Thermotoga maritima foi utilizada como grupo-externo, a barra indica dez substituições de em 100 nucleotídeos. Árvore construída pelo programa ARB com filtro LanemaskPH

Figura 63. Constituição da comunidade microbiana presente no RBS com 450 dias de operação. Microrganismo mais próximo filogeneticamente; porcentagem em relação à comunidade. .91

Figura 64. Curvas de rarefação de amostra do RLF sequenciadas utilizando primers universais a partir de análise utilizando DOTUR 
Figura 65. Árvore filogenética baseada em fragmento do gene rRNA 16S das 11 UTOs a partir de sequências encontradas nas amostras do RLF. Thermotoga maritima foi utilizada como grupo-externo, a barra indica dez substituições de em 100 nucleotídeos. Árvore construída pelo programa ARB com filtro LanemaskPH

Figura 66. Constituição da comunidade microbiana presente no RLF com 139 dias de operação. Microrganismo mais próximo filogeneticamente; porcentagem em relação à comunidade

Figura 67. Árvore filogenética baseada em fragmento do gene rRNA 16S das UTOs a partir de sequências encontradas nas amostras do RBS com primers específico (em roxo) e com primers universais (em vermelho), e do RLF (em azul). Thermotoga maritima foi utilizada como grupo-externo, a barra indica dez substituições de em 100 nucleotídeos. Árvore construída pelo programa ARB 99 


\section{LISTA DE TABELAS}

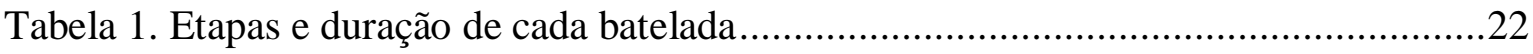

Tabela 2. Composição do meio basal de cultivo ............................................................22

Tabela 3. Composição da Solução Traço I......................................................................23

Tabela 4. Composição da Solução Traço II .................................................................23

Tabela 5. Parâmetros analisados em ensaios de atividade anammox específica .................25

Tabela 6. Valores de sólidos totais voláteis (g STV/L) nos diferentes quimiostatos ...........33

Tabela 7. Variação temporal da batelada 38 ( $89^{\circ}$ dia de operação) …................................35

Tabela 8. Etapas de operação durante a estratégia IV ....................................................39

Tabela 9. Valor de carga nitrogenada, eficiência de remoção e conversão e relação estequiométrica na Estratégia IV .................................................................. 45

Tabela 10. Frequências de agitação testadas $(\mathrm{N})$ e respectivas potências específicas

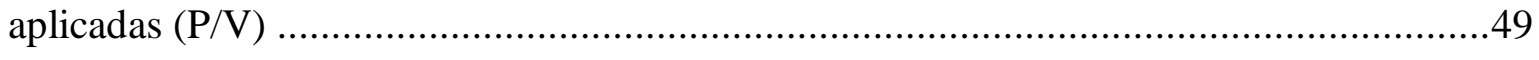

Tabela 11. Parâmetros cinéticos específicos da biomassa submetida a diferentes

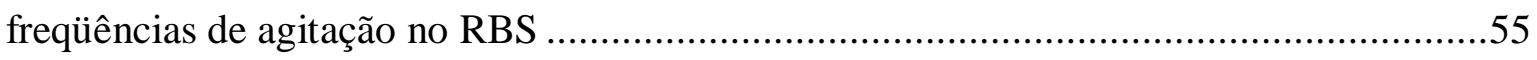

Tabela 12. Valores de atividade anammox específica encontrados por outros autores .......68

Tabela 13. Etapas de operação do Reator de Leito Fixo ...............................................69

Tabela 14. Valores de remoção de amônio e nitrito durante as etapas anammox de

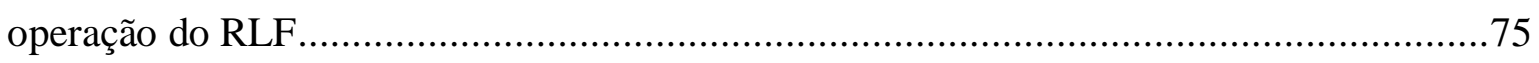

Tabela 15. Valores de carga nitrogenada, eficiência de remoção e conversão e relação

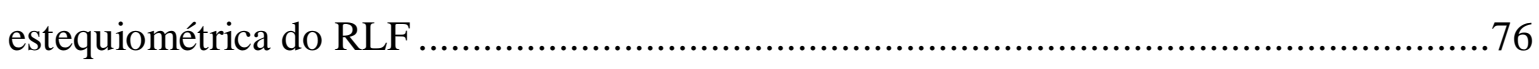

Tabela 16. Número de clones presentes em cada UTO (com similaridade mínima de 99\%)

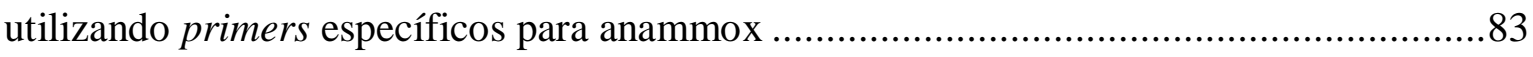


Tabela 17. Número de clones presentes em cada UTO (com similaridade mínima de 97\%) encontrada no sequenciamento da amostra do RBS utilizando primers universais para Bacteria

Tabela 18. Relação filogenéticadas UTOs obtidas do sequenciamento da amostra com 450 dias de operação do RBS

Tabela 19. Número de clones presentes em cada UTO (com similaridade mínima de 97\%) encontrada no sequenciamento da amostra do RLF utilizando primers universais para Bacteria.

Tabela 20. Relação filogenética das UTOs obtidas do sequenciamento da amostra com 139 dias de operação do RLF 95 


\section{INTRODUÇÃo}

A poluição dos corpos d'água por nitrogênio amoniacal causa eutrofização, principalmente devido ao crescimento da biomassa de algas. Além disso, o amônio é oxidado a nitrato diminuindo a quantidade de oxigênio dissolvido nos ecossistemas aquáticos, causando mortalidade da biota aeróbia. A ingestão de nitrato por humanos não tem impactos na saúde, no entanto, no trato gastrointestinal o nitrato é reduzido a nitrito. Esse último composto é cancerígeno, causa a meta-hemoglobinemia e sérios problemas no fígado, cérebro e sistema cardiovascular.

A resolução 357/2005 do CONAMA (BRASIL, 2005), que classifica os corpos de água, apresenta que os padrões de lançamentos não podem extrapolar o limite de 20,0 mg $\mathrm{N}-\mathrm{NH}_{4}{ }^{+} / \mathrm{L}, 1 \mathrm{mg} \mathrm{N}-\mathrm{NO}_{2}{ }^{-} / \mathrm{L}$ e $10 \mathrm{mgN}-\mathrm{NO}_{3}{ }^{-} / \mathrm{L}$.

O binômio nitrificação-desnitrificação já é consolidado como processo de remoção de nitrogênio em estações de tratamento de águas residuárias e esgoto sanitário.

A nitrificação é processo aeróbio em que o íon amônio é oxidado a nitrito por bactérias amônio-oxidantes (BAO), tais como: Nitrosomonas sp. e Nitrosospira sp. O nitrito é oxidado a nitrato por bactérias nitrito-oxidantes (BNO) relacionadas à Nitrobacter sp. e Nitrospira sp., sob condições aeróbias e autotróficas. Sob tais condições é necessária a aeração do sistema, a qual leva ao acréscimo no custo de operação.

$\mathrm{Na}$ desnitrificação o nitrato e nitrito são reduzidos a nitrogênio molecular $\left(\mathrm{N}_{2}\right)$ com oxidação da matéria orgânica carbonácea, geralmente expressa na forma de DQO (Demanda Química de Oxigênio), por vários grupos microbianos. No entanto, muitas águas residuárias, após a nitrificação, não possuem matéria orgânica suficiente, e a necessidade de adição de doador de elétrons para desnitrificação também levará ao incremento de custos adicionais. Biotecnologicamente, a nitrificação a nitrito é vantajosa, pois há economia de oxigênio na nitrificação e economia de matéria orgânica na desnitrificação.

Além da nitrificação, o nitrogênio amoniacal também pode ser oxidada na ausência de oxigênio molecular, no processo conhecido como anammox (acronímia de anaerobic 
ammonium oxidation). Esse processo envolve, conjuntamente, a remoção de nitrogênio na forma de amônio e nitrito. Portanto, o processo é extremamente vantajoso se acoplado à nitrificação curta (nitritação).

Os microrganismos nitrificantes amônio-oxidantes vivem em ambientes naturais (solo e corpos d'água) e antropogênicos (estações de tratamento de esgoto), e podem cooperar com bactérias anammox protegendo-as do oxigênio e provendo nitrito para oxidação anaeróbia do amônio. Essa é a base ecofisiológica para aplicação tecnológica no processo CANON ("Completely Autotrophic Nitrogen removal Over Nitrite”).

No processo CANON, amônio é parcialmente convertido a nitrito por bactérias amônio oxidantes aeróbias sob condições limitantes oxigênio. Subseqüentemente, bactérias anammox convertem o nitrito produzido junto com parte do amônio remanescente a nitrogênio gasoso e quantidade pequena de nitrato é formada.

Remoção considerável de nitrogênio foi reportada em reator com baixa concentração de oxigênio dissolvido e DQO afluente. É provável que nestes sistemas, um processo de desnitrificação autotrófica (redução do nitrato e oxidação do amônio) seja promovido por bactérias anammox (SLIEKERS et al., 2002). Bactérias que oxidam amônio a nitrito necessitam de oxigênio, enquanto bactérias que convertem nitrito a nitrogênio gasoso são anaeróbias. SLIEKERS et al. (2003) verificaram que ambas as bactérias podem co-existir no mesmo reator, desde que o sistema seja mantido em condições limitantes de oxigênio.

A aplicação do processo anammox para remoção de nitrogênio pode reduzir os custos operacionais em até 90\% (JETTEN et al., 2001), de águas residuárias contendo elevada concentração de nitrogênio e reduzida concentração de matéria orgânica como, por exemplo, efluente de digestor de lodo.

Existem muitos estudos em andamento na Europa sobre os processos de nitrificação junto com anammox. No entanto, estudos sobre estes processos em países de clima tropical ainda são escassos.

A presente pesquisa de doutorado buscou avaliar a influência de micronutrientes na nitrificação, enriquecer comunidade capaz de realizar a oxidação anaeróbia do amônio (anammox) e estabelecer biofilme nitrificante-anammox em meio suporte presente em reator de leito fixo. Para avaliação da eficiência de remoção dos compostos nitrogenados e caracterização dos microrganismos envolvidos nesses processos foram utilizados reator operado em bateladas seqüenciais e reator de leito fixo com fluxo ascendente. 


\section{HIPÓTESE}

A hipótese deste trabalho foi dividida em duas partes. A primeira supõe que é possível obter biomassa capaz de oxidar nitrogênio amoniacal a nitrogênio molecular (processo anammox) a partir de lodo de reator nitrificante-desnitrificante submetido a elevadas cargas de nitrogênio amoniacal. A segunda parte prevê que é possível estabelecer biofilme aeróbio-anóxico em suporte inerte em reator contínuo aerado. Tal biofilme será composto externamente por bactérias nitritantes e internamente por bactérias anammox, e será capaz de remover nitrogênio amoniacal em reator de leito fixo. 


\section{OBJETIVO}

\subsection{OBJETIVO GERAL}

Enriquecer consórcio anammox em reator operado em bateladas sequenciais (RBS). Avaliar a eficiência de remoção de nitrogênio em RBS contendo a biomassa enriquecida submetido à crescente carga nitrogenada aplicada. Avaliar a eficiência de remoção de nitrogênio em reator de leito fixo, preenchido com meio suporte de Poli Etileno de Baixa Densidade (PEBD), alimentado com meio mineral autotrófico com aumento gradual da concentração afluente de amônio e nitrito, e posteriormente somente amônio visando a nitrificação-anammox.

\subsection{OBJETIVOS ESPECÍFICOS}

- Avaliar a influência de micronutrientes na nitrificação;

- Avaliar a influência da frequiência de agitação, temperatura e concentração de nitrogênio inicial por ensaios de atividade anammox específica (AAE);

- Caracterizar a comunidade microbiana por meio de exames microscópicos;

- Estudar a comunidade microbiana envolvida na remoção de nitrogênio: (a) em reator operado em bateladas seqüenciais sob condições anammox; (b) em reator de leito fixo de fluxo ascendente alimentado com meio autotrófico.

- Identificar as comunidades microbianas em cada condição de alimentação utilizando fragmentos do gene RNAr $16 \mathrm{~S}$ por clonagem, sequenciamento e análise filogenética; 


\section{REVISÃo BiBLIOGRÁFICA}

\subsection{NITRIFICAÇÃO}

Segundo BOCK \& WAGNER (2006), a transformação de amônio em nitrato via nitrito pelas bactérias nitrificantes tem várias implicações diretas e indiretas para sistemas naturais e artificiais. Por exemplo, o processo de nitrificação pode contribuir, direta ou indiretamente, nos vários ambientes por meio da:

1. Lixiviação de compostos nitrogenados produzidos por bactérias nitrificantes. A lixiviação é a mobilização e transferência de nitrato de solos para rios, lagos, mar e águas subterrâneas. Nitrificação não é desejável no solo agrícola, porque induz a perda de nitrogênio nesse ambiente. Quando convertido em nitrato, o nitrogênio inorgânico do solo torna-se móvel e, portanto, suscetível a desnitrificação e lixiviação.

2. Desnitrificação: consiste na redução microbiana do nitrato via nitrito, óxido nítrico $(\mathrm{NO})$ e óxido nitroso $\left(\mathrm{N}_{2} \mathrm{O}\right)$ para nitrogênio molecular $\left(\mathrm{N}_{2}\right)$. Esse tipo de respiração anóxica é realizada por variedade de microrganismos filogeneticamente diferentes. Pela oxidação aeróbia de amônio em nitrato, nitrificantes produzem o receptor de elétrons para desnitrificação em muitos sistemas naturais e artificiais. Durante os últimos anos, foram listadas algumas bactérias nitrificantes capazes, também, de realizar a desnitrificação. Na ausência de oxigênio dissolvido, Nitrosomonas eutropha e Nitrosomonas europaea são capazes de realizar a desnitrificação usando hidrogênio molecular ou compostos orgânicos simples, tais como, acetato, piruvato e formiato como doadores de elétrons e nitrito como receptor de elétrons (BOCK et al., 1995).

3. Desnitrificação química de nitrito (produzido pelas BAO) em ambientes ácidos: é definida como a perda não-enzimática de nitrogênio devido à dismutação de ácido nítrico em $\mathrm{pH}<4,5$ levando à formação de nitrato e óxido nítrico gasoso. Na atmosfera, em presença de vapor d'água, o óxido nítrico é instável e reage com oxigênio ou ozônio para formar dióxido de nitrogênio, que quimicamente, transforma-se em ácido nítrico e ácido nitroso. 
LAANBROEK \& GERARDS (1993) verificaram que a redução da concentração de oxigênio em cultura mista de Nitrosomonas europaea e Nitrobacter winogradskyi inibiu a oxidação de nitrito em maior proporção que a oxidação de amônio, ocorrendo acúmulo de nitrito no reator.

No entanto, em alguns processos, tais como SHARON e CANON, os quais serão descritos posteriormente, ocorre nitrificação parcial de amônio até nitrito que pode, juntamente com o amônio remanescente, participar do processo anammox. Portanto, isso implica em concentrações razoáveis de nitrito no meio. Nestes casos, precauções especiais devem ser tomadas devido aos riscos da presença de nitrito efluente, pois, devido à sua toxicidade, pode trazer prejuízos para as plantas, fauna aquática, microrganismos nitrificantes e para saúde humana em virtude de seu potencial carcinogênico (PHILIPS \& VERSTRAETE, 2001).

Pesquisadores têm desenvolvido métodos e estratégias para manter a nitrificação parcial. O principal objetivo desta abordagem consiste em manter no sistema bactérias amônio oxidantes (BAO) e lavar do sistema as bactérias nitrito oxidantes (BNO) ou mantêlas inibidas baseando-se na ecofisiologia diferenciada destes grupos microbianos. Os principais parâmetros envolvidos são os seguintes: temperatura, $\mathrm{pH}$, concentração de oxigênio dissolvido, concentração de substratos nitrogenados e presença de inibidores.

Além disso, bactérias nitrito oxidantes (BNO) como Nitrobacter winogradskyi, $N$. hamburgensis e $N$. vulgaris podem crescer heterotroficamente com acetato ou piruvato como doador de elétrons e oxigênio molecular ou nitrato (na ausência de oxigênio molecular) como receptor de elétrons (FREITAG et al., 1987). No entanto, para esses organismos o crescimento sob condições heterotróficas foi sempre mais lento do que o crescimento autotrófico.

A elevada temperatura e reduzido tempo de retenção hidráulica (TRH) atuam selecionando BAO. Por exemplo, a $35^{\circ} \mathrm{C}$ a velocidade máxima de crescimento ( $\mu$ max) de BNO é aproximadamente a metade daquela observada para as BAO, ou seja; $0,5 \mathrm{~d}^{-1}$ e $1 \mathrm{~d}^{-}$ ${ }^{1}$, respectivamente (JETTEN, 2001).

$\mathrm{O}$ valor de Ks para concentração de oxigênio dissolvido (OD) para BAO e BNO são, respectivamente, 0,2-0,4mg/L e 1,2-1,5mg/L (PICIOREANU et al., 1997). Portanto, baixas concentrações de OD são mais restritivas às nitrito-oxidantes. O possível mecanismo de inibição pela baixa concentração de OD é em função da acumulação de hidroxilamina $\left(\mathrm{NH}_{2} \mathrm{OH}\right)$, que é intermediário metabólico da oxidação do amônio. Esta 
oxidação ocorre em dois passos: primeiro, amônio é oxidado a hidroxilamina pela enzima amônia monooxigenase (AMO), e então, hidroxilamina é oxidada a nitrito catalizada pela hidroxilamina oxidorredutase. Portanto, excesso de amônio e baixas concentrações de OD podem levar ao acúmulo de hidroxilamina (PAREDES et al., 2007).

A inibição por hidroxilamina é irreversível, e nenhuma oxidação de nitrito ocorre com 0,42mg N-NH${ }_{2} \mathrm{OH} / \mathrm{L}$ (PENG \& ZHU, 2006).

$\mathrm{O}$ pH tem papel fundamental na proporção dos compostos nitrogenados e suas formas ionizadas, por exemplo, em relação a amônio/amônia $\left(\mathrm{NH}_{4}{ }^{+} / \mathrm{NH}_{3}\right)$ e nitrito/ácido nitroso $\left(\mathrm{NO}_{2}{ }^{-} / \mathrm{HNO}_{2}\right)$.

A amônia livre é inibidora competitiva da atividade da nitrito oxidorredutase que está localizada na membrana de BNO (YANG \& ALLEMAN, 1992). A concentração de amonia livre e ácido nitroso livre em função do $\mathrm{pH}$ estão representadas pelas equações $1 \mathrm{e}$ 2 (ANTHONISEN et al., 1976).

Amônia livre $\left(\mathrm{NH}_{3}\right)=\frac{17}{14} \cdot \frac{\left[\mathrm{N}-\mathrm{NH}_{4}^{+}\right] * 10^{\mathrm{pH}}}{\mathrm{K}_{\mathrm{a}} / \mathrm{KW}+10^{\mathrm{pH}}}$

Sendo: $\mathrm{K}_{\mathrm{a}} / \mathrm{K}_{\mathrm{w}}=\mathrm{e}^{6344(273+\mathrm{T})}$

Ácido nitroso livre $\left(\mathrm{HNO}_{2}\right)=\frac{46}{14} \cdot \frac{\left[\mathrm{N}^{\left.-\mathrm{NO}_{2}{ }^{-}\right]}\right.}{\mathrm{e}^{-2300 /\left(273+\mathrm{T}^{\circ} \mathrm{C}\right)} * 10^{\mathrm{pH}}}$

Valores acima de $7 \mathrm{mgN}-\mathrm{NH}_{3} / \mathrm{L}$ inibem parcialmente a oxidação do amônio e a oxidação cessa completamente com 20mgN-NH $3 / \mathrm{L}$ (ABELING \& SEYFRIED, 1992). Culturas de Nitrobacter adaptadas a concentrações crescentes de amônia livre toleram até $40 \mathrm{mgN}-\mathrm{NH}_{3} / \mathrm{L}$, enquanto culturas não adaptadas são inibidas com $3,5 \mathrm{mgN}-\mathrm{NH}_{3} / \mathrm{L}$ (WONGCHONG \& LOEHR, 1978). No entanto, KIM et al., (2003) observaram acúmulo de nitrito baseando-se na inibição por amônia livre $(0,2 \mathrm{mg} / \mathrm{L})$ e condição limitante de oxigênio (1-2mg OD /L). Segundo PENG \& ZHOU (2006), a amônia livre tem efeito inibidor sobre as BNO, mas esta inibição é reversível.

A concentração de ácido nitroso varia em fução do $\mathrm{pH}$ e da concentração de nitrito no meio. $\mathrm{O}$ mecanismo proposto para inibição por ácido nitroso sugere que este atua como desacoplador por colocar próton dentro da célula. Esse próton interfere diretamente no gradiente de $\mathrm{pH}$ na membrana requerido para síntese de ATP (GLASS et al., 1997). Segundo ANTHONISEN et. al. (1976), valores acima de 2,8mg $\mathrm{HNO}_{2} / \mathrm{L}$ inibem tanto as 
BAO quanto as BNO, e entre 0,2 e 2,8mg $\mathrm{HNO}_{2} / \mathrm{L}$ podem inibir as BNO.

NOWAK et. al. (1996) investigaram o efeito da concentração do fósforo na nitrificação. O coeficiente de meia saturação (Ks) para fósforo para as BAO e as BNO são respectivamente, 0,2mg $\mathrm{P}-\mathrm{PO}_{4}^{-} / \mathrm{L}$ e $0,03 \mathrm{mg} \mathrm{P}_{-} \mathrm{PO}_{4}{ }^{-} / \mathrm{L}$. Os pesquisadores observaram redução substancial da nitratação em concentações abaixo de $0,2 \mathrm{mg} \mathrm{P}_{-} \mathrm{PO}_{4}{ }^{-} / \mathrm{L}$ e nomearam esta estratégia de bloqueio do fosfato.

GRUNDITZ et al. (1998) realizaram ensaios, em três grupos microbianos, bactérias amônio-oxidantes, nitrito-oxidantes e nitrito redutores para verificar inibição por metais. Os seguintes metais foram testados: cromo $0,7-785 \mu \mathrm{g} / \mathrm{L}$, níquel 3-860 $\mu \mathrm{g} / \mathrm{L}$, cobre 3-5730 $\mu \mathrm{g} / \mathrm{L}$, zinco 3-1000 $\mu \mathrm{g} / \mathrm{L}$, chumbo 0,09-1680 $\mu \mathrm{g} / \mathrm{L}$ e cádmio 0,01 $20 \mu \mathrm{g} / \mathrm{L}$. Os ensaios revelaram que os três grupos foram inibidos por zinco. Bactérias amônio-oxidantes foram inibidas também por cobre, as BNO por níquel e bactérias nitrito redutores foram inibidas por chumbo. Os autores não informaram em quais concentrações ocorreram as inibições.

\subsection{PROCESSOS SHARON E CANON}

O processo SHARON (“Single reactor system for High Ammonium Removal Over Nitrite") é técnica empregada para tratamento biológico de efluentes com elevadas cargas de nitrogênio. $\mathrm{O}$ amônio é parcialmente convertido a nitrito sob condições aeróbias por bactérias amônio-oxidantes (Nitrosomonas sp.), de acordo com a reação (3).

$$
\mathrm{NH}_{4}^{+}+1,5 \mathrm{O}_{2} \rightarrow \mathrm{NO}_{2}^{-}+\mathrm{H}_{2} \mathrm{O}+2 \mathrm{H}^{+} \quad \Delta \mathrm{G}^{\circ}=-275 \mathrm{~kJ}
$$

Devido ao reduzido TRH (Tempo de Retenção Hidráulica) de aproximadamente 1 dia, temperatura elevada (acima de $30^{\circ} \mathrm{C}$ ) e sistema operado sem retenção de lodo e sem controle de $\mathrm{pH}$, as bactérias nitrito-oxidantes; tais como, Nitrobacter sp. e Nitrospira sp. são lavadas do reator.

O processo CANON é uma opção econômica e eficiente para o tratamento de águas residuais, especialmente para as águas residuárias ricas em amônio e desprovidas de carbono orgânico. O processo CANON ocorre em condição autotrófica e, portanto, não requer DQO adicional. Além disso, a remoção total do nitrogênio pode ser alcançada em único reator com aeração reduzida. Este processo consume $63 \%$ menos oxigênio e $100 \%$ menos agentes redutores do que o processo convencional de remoção de nitrogênio (KHIN 
\& ANNACHHATRE, 2004).

SLIEKERS et. al. (2002) operaram reator em batelada sequencial de 2L com agitação de $100 \mathrm{rpm}$ mantido a $30^{\circ} \mathrm{C}$ sob condições de microaerofilia $(0,02 \mathrm{mg} \mathrm{OD} / \mathrm{L})$ e $\mathrm{pH}$ 7,8 inoculado com biomassa composta por $80 \%$ anammox (STROUS et al., 1998). Neste reator, os autores relataram que a biomassa predominante, após 50 dias, foi composta de BAO e bactérias anammox com capacidade de remoção de $64 \mathrm{mg}$ N/L dia, e $75 \mathrm{mg} \mathrm{N}$ $\mathrm{NH}_{4}{ }^{+} / \mathrm{L}$ dia. A velocidade de conversão de amônio foi de $150 \mathrm{mg} \mathrm{N}$ - $\mathrm{NH}_{4}{ }^{+} /$dia, e atividade de $100 \mathrm{mg} \mathrm{NH}_{4}{ }^{+} / \mathrm{g}$ massa seca.dia. Os autores não detectaram óxido nitroso $\left(\mathrm{N}_{2} \mathrm{O}\right)$ e óxido nítrico (NO) no biogás, assim como não foi detectada atividade desnitrificante. Esse novo processo foi chamado de CANON.

Considerando que bactérias anammox são reversivelmente inibidas por baixas concentrações de oxigênio ( $0,5 \%$ da saturação do ar), para que o processo CANON possa ocorrer em único reator, a oxidação aeróbia do amônio deve remover todo o oxigênio da fase líquida (SLIEKERS et al., 2002), ou do biofilme. Para tanto, o fluxo de entrada de amônio no reator deve ser mantido acima do fluxo de entrada de oxigênio (SLIEKERS et al., 2003).

HAO et al. (2002) desenvolveram modelo matemático e avaliaram os parâmetros relevantes envolvidos no processo CANON em reator com biofilme. Carga superficial de $2 \mathrm{gN} / \mathrm{m}^{2}$.d, associada a $1,3 \mathrm{mgO}_{2} / \mathrm{L}$ no líquido, com mínimo de $1 \mathrm{~mm}$ de profundidade do biofilme pareceram ser as condições apropriadas para a remoção de amônio em reator de único estágio. Sob essas condições e à temperatura de $30^{\circ} \mathrm{C}$, a eficiência de remoção de amônio foi de $94 \%$ ( $82 \%$ de eficiência de remoção de nitrogênio total). Os autores mencionaram que melhor eficiência de remoção de amônio poderia ser alcançada com aumento da concentração de oxigênio dissolvido, mas isto limitaria fortemente o processo anammox.

\subsection{ANAMMOX}

O habitat natural de bactérias anammox situa-se na interface óxica-anóxica onde estão presentes os substratos nitrogenados (amônio e nitrito). O amônio é produzido pela decomposição anaeróbia da matéria orgânica tanto pela amonificação quanto pela redução dissimilatória do nitrato/nitrito. O nitrito pode ser produzido pela redução do nitrato, tanto por desnitrificação (autotrófica ou heterotrófica) quanto por bactérias anammox em 
presença de formiato, acetato ou propionato (KARTAL et al., 2007a). Na zona aeróbia, o nitrito é produto da nitrificação por bactérias amônio-oxidantes (BAO) ou arquéias amônio-oxidantes (AAO) (FRANCIS et al., 2007), podendo difundir para zona anóxica.

$\mathrm{Na}$ interface oxica-anóxica (biofilme, sedimento ou corpos d'água estratificados) pode ocorrer interação e competição entre três grupos de microrganismos: microrganismos amônio e nitrito oxidantes competem pelo oxigênio; amônio oxidantes e nitrito oxidantes competem com bactérias anammox por amônio e nitrito, respectivamente. Neste ambiente BAO tem papel chave no ciclo, pois seu produto (nitrito) é substrato para os demais grupos de microrganismos (KUENEN, 2008).

As bactérias anammox referem-se a mais recente inclusão de microrganismos atuantes no ciclo biogeoquímico do nitrogênio. Tais microrganismos obtêm sua energia para o crescimento a partir da conversão de amônio e nitrito em gás nitrogênio, na ausência de oxigênio, e utilizam fonte de carbono inorgânico. Nesse metabolismo, ocorre a formação de hidrazina, um composto intermediário muito reativo e tóxico.

Bactérias anammox são caracterizadas por uma arquitetura celular diferenciada pela presença de um compartimento central, denominado "anamoxossomo". Estes microrganismos de crescimento lento pertencem à ordem Brocadiales e são filiados à Planctomycetes (JETTEN et al., 2009).

O genoma da bactéria anammox Kuenenia stuttgartiensis foi obtido a partir de comunidade microbiana crescida em reator de batelada $(74 \%$ enriquecido com esta bactéria), utilizando abordagem metagenômica. O genoma obtido permitiu a reconstrução in silico ${ }^{1}$ do metabolismo anammox e identificação de genes provavelmente envolvidos no processo (JETTEN et al., 2009).

O hábitat das bactérias anammox já foi estabelecido em ambientes muito limitados em oxigênio, incluindo oceanos, mares, estuários, pântanos, rios e lagos. No ambiente marinho mais de $50 \%$ do gás $\mathrm{N}_{2}$ liberado pode ser produzido por bactérias anammox (DALSGAARD et al., 2005). A aplicação deste processo oferece uma alternativa atrativa aos sistemas atuais de tratamento de águas residuais para a remoção de nitrogênio

${ }^{1}$ In silico é uma expressão usada no âmbito da simulação computacional e áreas correlatas para indicar algo ocorrido por meio de uma simulação computacional. A expressão foi cunhada a partir das expressões latinas in vivo e in vitro. In silico é, originalmente, usada apenas para denotar simulações computacionais que modelam um processo natural ou de laboratório e não para cálculos computacionais genéricos (DANCHIN et al., 1991). 
amoniacal.

MULDER et al. (1995) descobriram a oxidação anaeróbia do amônio (anammox) em reator desnitrificante de leito fluidizado em escala de bancada utilizado no tratamento de efluentes de reator metanogênico. Grandes quantidades de amônio foram removidas com consumo de nitrato e produção de gás nitrogênio (Eq. 4). Sob tais condições, VAN DE GRAAF et al. (1995) observaram que o nitrito foi o receptor de elétrons preferencial para o processo (Eq. 5).

$$
\begin{array}{llr}
5 \mathrm{NH}_{4}^{+}+3 \mathrm{NO}_{3}^{-} \longrightarrow & 4 \mathrm{~N}_{2}+9 \mathrm{H}_{2} \mathrm{O}+2 \mathrm{H}^{+} & \Delta \mathrm{G}^{\circ}=-297 \mathrm{~kJ} \\
\mathrm{NH}_{4}{ }^{+}+\mathrm{NO}_{2}^{-} \longrightarrow & \mathrm{N}_{2}+2 \mathrm{H}_{2} \mathrm{O} & \Delta \mathrm{G}^{\circ}=-357 \mathrm{~kJ}
\end{array}
$$

O principal produto de oxidação anaeróbia de amônio foi $\mathrm{N}_{2}$. No entanto, cerca de $10 \%$ do nitrogênio afluente (nitrito e amônio) foi convertido para $\mathrm{NO}_{3}$. O balanço de nitrogênio total (Eq. 6) foi observado para razão de conversão $\mathrm{NH}_{4}{ }^{+}: \mathrm{NO}_{2}{ }^{-}$de $1: 1,31 \mathrm{e}$ proporção de conversão de amônio e produção de nitrato, $\mathrm{NH}_{4}{ }^{+}$: $\mathrm{NO}_{3}{ }^{-}$de 1:0,22 (VAN DE GRAAF et al., 1996).

$$
\begin{aligned}
1 \mathrm{NH}_{4}{ }^{+} & +1,31 \mathrm{NO}_{2}^{-}+0,045 \mathrm{HCO}_{3}^{-} \longrightarrow \\
& \longrightarrow 1,045 \mathrm{~N}_{2}+0,22 \mathrm{NO}_{3}{ }^{-}+0,045 \mathrm{CH}_{2} \mathrm{O}_{0,5}+1,87 \mathrm{H}_{2} \mathrm{O}+0,09 \mathrm{OH}^{-}
\end{aligned}
$$

STROUS et al. (1998) estimaram a estequiometria anammox com base no balanço de massa sobre culturas anammox enriquecidas, conforme apresentado na equação (7):

$$
\begin{aligned}
1 \mathrm{NH}_{4}{ }^{+}+1,32 \mathrm{NO}_{2}{ }^{-}+0,066 \mathrm{HCO}_{3}{ }^{-}+0,13 \mathrm{H}^{+} & \longrightarrow \\
& \longrightarrow 1,02 \mathrm{~N}_{2}+0,26 \mathrm{NO}_{3}{ }^{-}+0,066 \mathrm{CH}_{2} \mathrm{O}_{0,5} \mathrm{~N}_{0,15}+2,03 \mathrm{H}_{2} \mathrm{O}
\end{aligned}
$$

O processo anammox envolve a oxidação do amônio, utilizando nitrito como receptor de elétrons, para produzir nitrogênio gasoso (Eqs. 5, 6 e 7). A nitrificação ocorre segundo as Equações 3 (nitritação) ou 8 (nitritação mais nitratação). Tais equações demonstram que o processo anammox é energeticamente mais favorável que a nitrificação (JETTEN et al., 1998).

$$
\mathrm{NH}_{4}{ }^{+}+2 \mathrm{O}_{2} \longrightarrow \mathrm{NO}_{3}^{-}+2 \mathrm{H}^{+}+\mathrm{H}_{2} \mathrm{O} \quad \Delta \mathrm{G}^{\circ}=-349 \mathrm{~kJ}
$$


A influência do oxigênio no processo anammox foi investigada por STROUS et al. (1997a) em reator de leito fluidificado e de batelada. O primeiro reator foi monitorado durante 20 dias, com ciclos de $2 \mathrm{~h}$ alternados com aeração $\left(\mathrm{O}_{2}\right)$ e anaerobiose (argônio). $\mathrm{O}$ processo anammox foi observado, somente, nos períodos anaeróbios. No período aeróbio, não foi observado decréscimo do amônio por nitrificação. Nos reatores em batelada não foi verificada a ocorrência da anammox em microaerofilia, para concentrações de oxigênio iguais a 2, 1, 0,5\% da saturação. Porém, o processo foi restabelecido sob anaerobiose, demonstrando que a inibição pelo oxigênio foi reversível.

THIRD et al. (2005) enriqueceram biomassa anammox a partir de lodos ativados de estação de tratamento de Subiaco (Austrália Ocidental) em 14 semanas. A máxima atividade anammox desta biomassa foi 3,64 $\mathrm{g} \mathrm{NH}_{4}{ }^{+} / \mathrm{g} \mathrm{SST} \mathrm{h}$, com remoção de $0,58 \mathrm{~kg} \mathrm{~N}$ total $/ \mathrm{m}^{3}$ dia. Posteriormente, foi adicionada pequena quantidade de biomassa nitrificante $(10 \% \mathrm{v} / \mathrm{v})$ para iniciar o processo CANON em quimiostato. O reator CANON foi operado sob aeração intermitente (aerobiose $20 \mathrm{~min}$ e $30 \mathrm{~min}$ de anaerobiose). A biomassa anammox não foi inibida por oxigênio; no entanto, a remoção de nitrogênio diminuiu para $0,08 \mathrm{~m} \mathrm{~N} \mathrm{~kg} / \mathrm{m}^{3}$ dia.

O primeiro reator anammox em escala plena teve sua partida em Rotterdã-Holanda e teve como inóculo lodo nitrificante da estação de tratamento de Dokhaven. O reator de $70 \mathrm{~m}^{3}$ trata até $750 \mathrm{~kg} \mathrm{~N} / \mathrm{d}$. Na fase inicial da partida, as conversões anammox não puderam ser identificadas por métodos tradicionais. Todavia, a técnica de PCR quantitativo foi indicador confiável do crescimento da população anammox. Tal possibilidade permitiu determinar tempo de duplicação de 10-12 dias para essas bactérias (VAN DER STAR et al., 2007).

\subsubsection{Taxonomia e Aspectos Fisiológicos}

A análise filogenética demonstrou que gêneros de bactéria anammox são monofiléticos (Candidatus "Scalindua", Candidatus "Brocadia", Candidatus "Kuennenia", Candidatus "Anammoxoglobus" e Candidatus "Jettenia") e ramificam-se precocemente na linhagem de descendência de Planctomycete. Todos os gêneros têm o mesmo metabolismo e semelhante ultra-estrutura (caracterizada pela presença do anammoxossomo). Assim, sabe-se que a capacidade metabólica para anammox evoluiu apenas uma vez. O termo "Candidatus" foi mostrado aqui apenas como referência de que nenhuma espécie 
anammox foi obtida ainda em cultura pura. No entanto, como as espécies anammox já foram encontradas há algum tempo o termo não será mais mostrado neste trabalho.

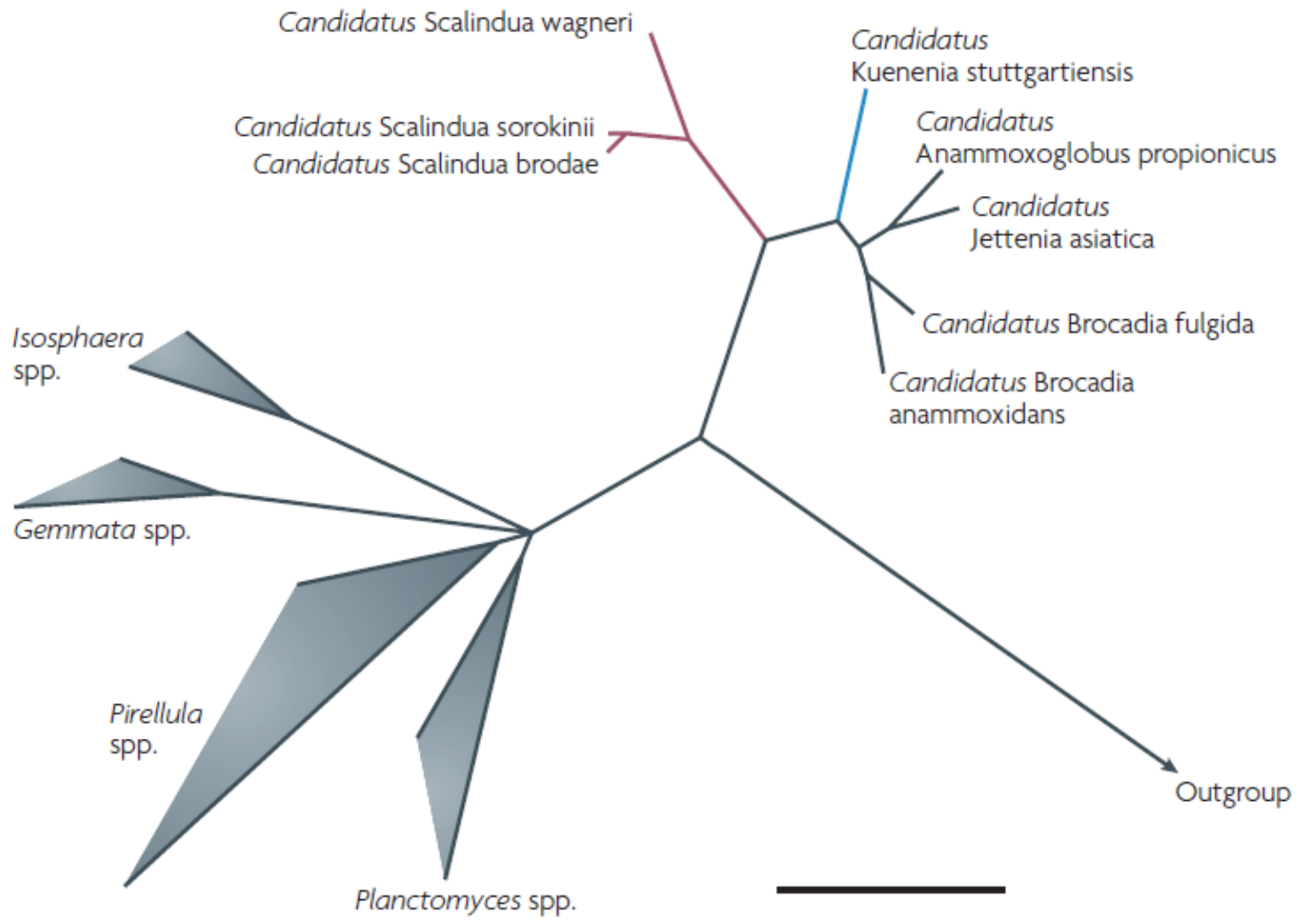

Figura 1. Arvore filogenética do filo Planctomycete baseada na sequência do gene do RNA ribossomal 16S. A barra de escala representa 10\% de divergência filogenética. Adaptado de (KUENEN, 2008)

Ainda, as distâncias evolutivas entre os gêneros anammox são grandes; espécie de Scalindua sp. e Brocadia sp., em média, têm sequência de apenas $85 \%$ identidade do RNAr 16S. Para a comparação, duas espécies de Proteobactérias igualmente diferentes em relação à identidade do gene RNAr 16S, tem fenótipos completamente diferentes, ou seja, Nitrosomonas europeae e Neisseria gonnorhoeae também têm $85 \%$ de identidade e metabolismos bem distintos (STROUS \& JETTEN, 2004).

Cinco gêneros anammox foram descritos, com identidades do gene RNAr 16S das espécies que vão entre 85 e 99\% (JETTEN et al., 2009). Quatro gêneros anammox foram enriquecidos a partir de lodos de estações de tratamento: Kuenenia (SCHMID et al., 2000; STROUS et al., 2006), Brocadia (STROUS et al., 1999a), Anammoxoglobus (KARTAL et al., 2007b) e Jettenia (QUAN et al., 2008). O quinto gênero, Scalindua (KUYPERS et al., 2003; SCHMID et al., 2003), tem sido 
frequientemente detectado em habitats naturais, especialmente em sedimentos marinhos e zonas com mínima concentração de oxigênio (DALSGAARD et al., 2005; SCHMID et al., 2007).

Brocadia anammoxidans foi a primeira bactéria anammox identificada (STROUS et al., 1999a). Segundo os autores, a purificação $(99,6 \%)$ foi realizada utilizando protocolo de centrifugação em gradiente de densidade com Percoll. A espécie foi isolada de reator operado em bateladas sequenciais e apresentava atividade anammox específica de $35 \mathrm{mg}$ $\mathrm{N}-\mathrm{NH}_{4}{ }^{+} / \mathrm{g}$ SSV h (STROUS et al., 1998).

As bactérias anammox são mais versáteis metabolicamente do que se pensava. Além do metabolismo usual, autotrófico, são capazes de crescer em meio contendo ácidos orgânicos como doadores de elétrons para redução de nitrito e nitrato (GUVEN et al., 2005; KARTAL et al., 2007b).

Nova espécie anammox foi enriquecida em RBS em escala de laboratório, na presença de amônio e propionato a partir de lodo ativado da estação de tratamento de Dokhaven em Roterdan, Holanda. Nos primeiros 4 meses após a inoculação do RBS, as concentrações de nitrito e amônio foram aumentadas gradativamente de 35 a $630 \mathrm{mgN} / \mathrm{L}$. A concentração afluente de nitrato foi mantida em $84 \mathrm{mg} \mathrm{N}^{-N_{3}}{ }_{3} / \mathrm{L}$ durante todo o tempo. Paralelamente ao aumento de nitrito e amônio, a concentração de propionato foi aumentada de 58,4 para $1.095 \mathrm{mg} / \mathrm{L}$. Segundo os autores, esta espécie pode competir com outras bactérias anammox e outros microrganismos desnitrificantes heterotróficas para a oxidação de propionato em ambientes contendo amônio, nitrito e nitrato. Esta nova espécie foi chamada de Anammoxoglobus propionicus (KARTAL et al., 2007b).

QUAN et al. (2008) avaliaram a comunidade microbiana de lodo granulado anammox proveniente de reator operado por cerca de um ano com elevada carga nitrogenada removida (até $0,8 \mathrm{~kg} \mathrm{~N}-\mathrm{NH}_{4}{ }^{+} / \mathrm{m}^{3}$ dia). A biblioteca específica do gene $\mathrm{RNAr}$ 16S para Planctomycetales foi construída. Quinze das dezesseis das sequências amplificadas foram semelhantes entre si (> 99\%), mas estavam distantes filogeneticamente das sequências conhecida no banco de dados. Análises de fragmento de 4008 pb do gene RNAr $16 \mathrm{~S} / 23 \mathrm{~S}$ do clone AS-1 presente no reator foi sequenciado e comparado com sequências de Planctomycetales, incluindo quatro gêneros candidatos anammox. A nova espécie foi chamada Jettenia Asiatica.

O genoma de $K$. stuttgartiensis (4,2 megabases) foi utilizado para deduzir as rotas metabólicas da oxidação anaeróbia do amônio (anammox). Já era conhecido que a 
hidrazina $\left(\mathrm{N}_{2} \mathrm{H}_{4}\right)$ é intermediário, e que as bactérias realizam oxidação de hidrazina a gás nitrogênio com a enzima hidrazina hidrolase (HH) (JETTEN et al., 2009). No genoma de K. stuttgartiensis foram detectados mais de 200 genes diretamente envolvidos no catabolismo e respiração, que é um número muito mais expressivo que encontrado em outros microrganismos e ,até agora só, observado em bactérias heterotróficas versáteis como Geobacter sulforreducens e Shewanella oneidensis (STROUS et al., 2006).

Foram encontrados e identificados os seguintes genes para o metabolismo anammox: nitrato nitrito oxidorredutase (narGH), óxido nítrico nitrito oxidorredutase (nirS), hidrazina hidrolase $(\mathrm{HH})$ e nove genes do grupo hidroxilamina/hidrazina oxidoredutase (HAO/HZO).

A presença de nitrato (narGH, capaz de oxidar nitrito a nitrato e vice versa) e nitrito (nirS) redutase que são conhecidas como enzimas atuantes nos primeiros passos da desnitrificação. No entanto, a ausência dos genes para óxido nítrico redutase e óxido nitroso redutase (enzimas da desnitrificação) sugerem rota diferente da desnitrificação convencional.

Curiosamente, tanto nitrito quanto o nitrato podem servir como receptores de elétrons, com amônio sendo o produto final. À medida que o organismo pode gerar tanto nitrito (do nitrato) quanto amônio (do nitrito), a conseqüência é que este organismo pode produzir os seus próprios receptores e doadores de elétrons. Essa via metabólica leva à produção de $\mathrm{N}_{2}$ por um caminho diferente da desnitrificação convencional (KARTAL et al., 2007a).

A rota metabólica anammox foi previamente postulada por VAN DE GRAAF et. al. (1997) e envolve hidrazina e hidroxilamina $\left(\mathrm{NH}_{2} \mathrm{OH}\right)$. No entanto, a presença do gene nirS não foi compatível com o metabolismo proposto por VAN DE GRAAF et al. (1997), em que o intermediário era hidroxilamina ao invés de óxido nítrico oriundo da reação da nirS.

A hidroxilamina/hidrazina oxidoredutase (HAO/HZO) é capaz de oxidar tanto hidroxilamina quanto hidrazina, esta última oxidada a nitrogênio molecular. A capacidade desta enzima de oxidar hidroxilamina, explica o metabolismo com hidroxilamina como intermediário metabólico proposto por VAN DER STAR et al. (2008b).

As bactérias anammox são todas Gram negativas e não foram, até o momento, obtidas em cultura pura. A técnica da centrifugação em gradiente de densidade com Percoll obtém o maior índice de pureza (um contaminante em 500) (STROUS et al., 
2002). Suas distintas características fenotípicas envolvem a coloração vermelha, reprodução por brotamento, estrutura da superfície da célula crateriforme, sendo o compartimento intracelular "anamoxossomo" com membrana intracitoplasmática contendo lipídeos em forma de escada "ladderane" (VAN DE GRAAF et al., 1996; LINDSAY et al., 2001; DAMSTE et al., 2002). Esta organela especial da célula, "anamoxossomo", tem três funções: (1) proporcionar espaço para catabolismo; (2) geração de energia para a síntese de ATP através de força próton motriz através da membrana do "anamoxossomo"; (3) proteger as bactérias da difusão dos prótons e toxicidade intermediária (hidrazina), devido à impermeabilidade sua membrana (LINDSAY et al., 2001).

Entre os Planctomycetes, as bactérias anammox são as únicas quimiolitoautotróficas conhecidas e, por isso, não se pôde prever a via metabólica para a fixação de carbono, apesar de algumas indicações obtidas a partir análises de carbono- $\mathrm{C}^{13}$ (SCHOUTEN et al., 2004); além disso, a falta de cultura pura dificulta o processo para definir as rotas metabólicas.

No entanto, em 2006, os genes da via metabólica de fixação de $\mathrm{CO}_{2}$ (WoodLjungdahl) foram todos encontrados no genoma de K. stuttgartiensis, enquanto para as outras vias metabólicas de fixação de carbono conhecidas os genes estão ausentes ou incompletos (STROUS et al., 2006). Na rota Wood-Ljundahl (acetil-CoA) duas moléculas de $\mathrm{CO}_{2}$ são reduzidas e incorporadas à coenzima $\mathrm{A}(\mathrm{HS}-\mathrm{CoA})$ na forma de acetil-CoA.

A via metabólica do acetil-CoA foi confirmada pela atividade de duas enzimaschave (formiato desidrogenase e monóxido de carbono desidrogenase) em extratos livre de células (STROUS et al., 2006). O Acetil-CoA é substrato intermediário da glicólise, Ciclo de Krebs (ciclo do ácido tricarboxílico) e, também da gliconeogênese. Além disso, faz parte de todas as rotas de síntese dos constituintes celulares.

Análises fisiológicas e moleculares revelaram que bactérias anammox podem oxidar formiato, acetato e propionato a dióxido de carbono (GUVEN et al., 2005). Os compostos orgânicos só foram dissimilados e não assimilados (a fonte de carbono para o crescimento foi inorgânica), como demonstrado em estudos utilizando isótopo radioativo do carbono (KARTAL et al., 2007b). Tanto óxidos de manganês como de ferro foram reduzidos utilizando-se formiato como doadores de elétrons, e o oxido ferroso pode ser oxidado com a redução de nitrato (STROUS et al., 2006), confirmando a versatilidade das bactérias anammox.

Sob tais considerações, o presente projeto teve como objetivo principal aprofundar 
estudos sobre a comunidade microbiana com ênfase nos aspectos fisiológicos e filogenéticos, principalmente relacionados com os processos de nitrificação-anammox, visando oferecer subsídios para aplicação no tratamento de águas residuárias com elevadas concentrações de amônio e baixas concentrações de matéria orgânica. 


\section{Material e Métodos}

\subsection{PROCEDIMENTO EXPERIMENTAL}

Inicialment, o lodo biológico de estação de tratamento de água residuária de indústria produtora de aminoácido, usado no tratamento de altas cargas de nitrogênio, foi enriquecido sob condições anammox em reator operado em bateladas sequenciais (RBS). A biomassa enriquecida no RBS foi submetida a ensaios fisiológicos de ensaios de atividade anammox específica variando-se a concentração dos compostos nitrogenados, temperatura e frequência dos propulsores no RBS.

Esse lodo enriquecido foi imobilizado em reator de leito fixo de fluxo ascendente (RLF) preenchido com polietileno de baixa densidade (PEBD). O RLF foi alimentado com meio mineral autotrófico.

Após estabelecimento do processo anammox, foi adicionado lodo ativado pela parte de cima do reator. Neste período, o RLF foi alimentado com o mesmo meio, porém, sem nitrito e contendo amônio na concentração inicial de $100 \mathrm{mg} \mathrm{N}-\mathrm{NH}_{4}{ }^{+} / \mathrm{L}$. Na região inferior do reator foi promovida aeração do meio $(20 \mathrm{~mL} /$ minuto) com compressor de aquário.

Foram realizadas análises de monitoramento de Nitrito, Nitrato, Amônio, pH e OD, assim como, análises microbiológicas e de biologia molecular, durante o período de operação dos reatores.

No $168^{\circ}$ e no $400^{\circ}$ dia de operação do RBS, e no $141^{\circ}$ dia de operação do RLF sob condições anammox foram retiradas amostras para análise filogenética. Foi feita identificação das comunidades utilizando fragmentos do gene RNAr 16S por clonagem, seqüenciamento e análise filogenética (Figura 2).

Também foram realizados ensaios em quimiostatos para se verificar a influência dos micronutrientes no processo de nitrificação (Figura 3). 


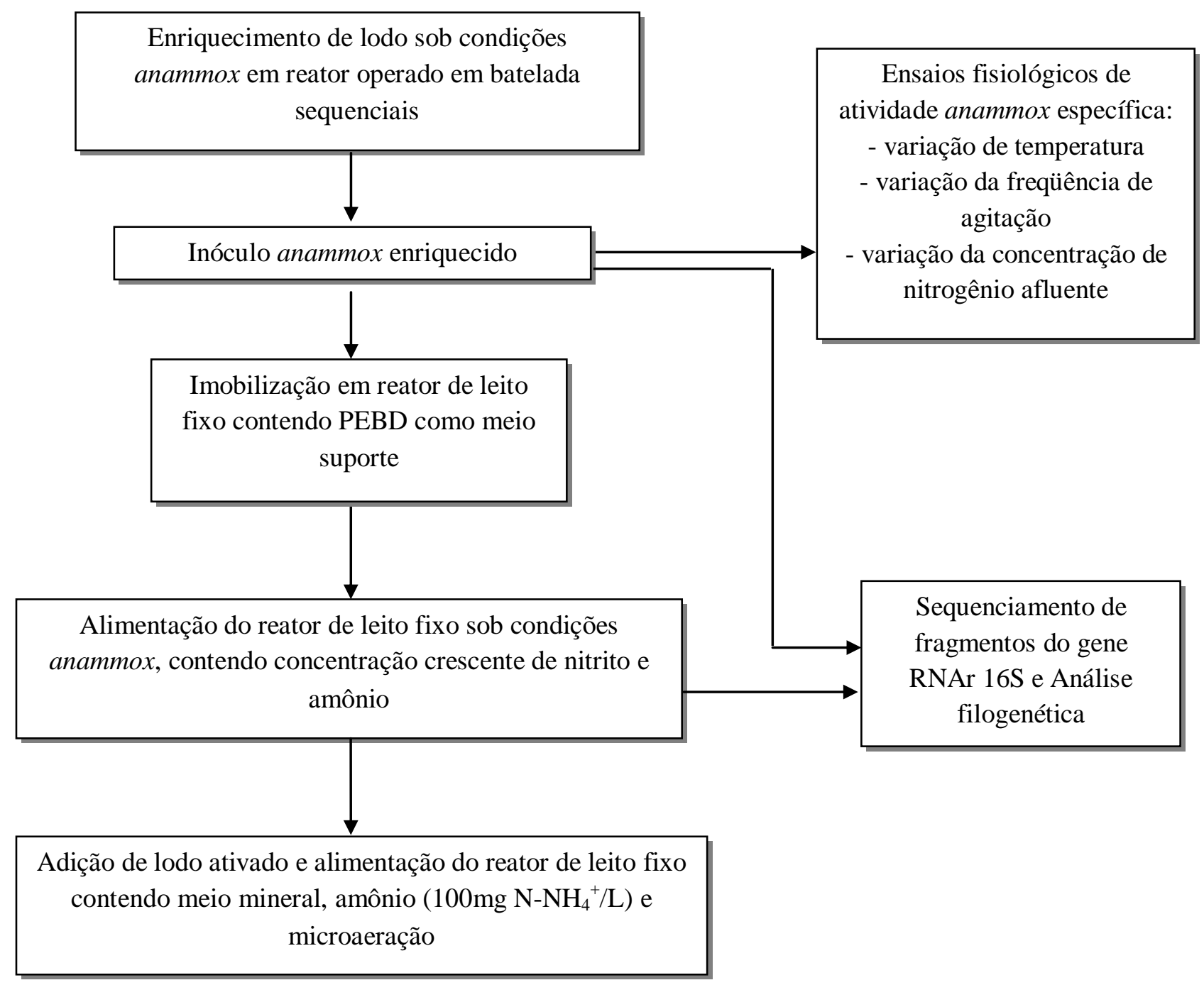

Figura 2. Fluxograma das etapas experimentais

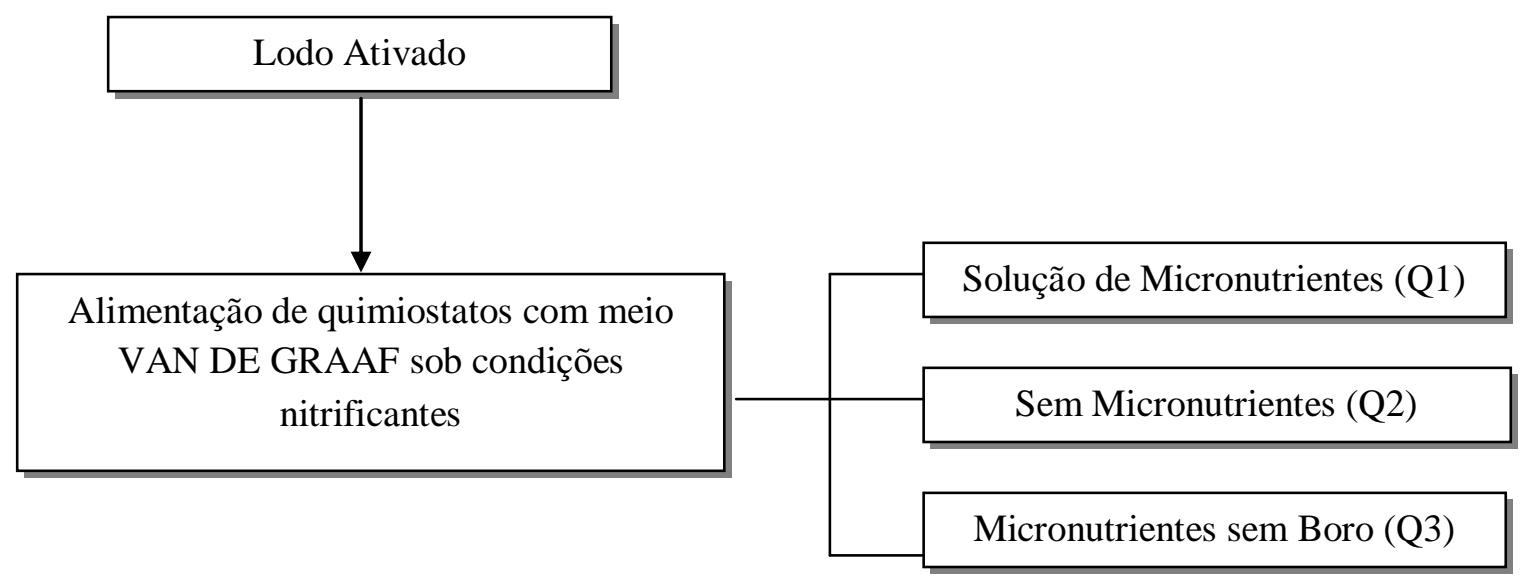

Figura 3. Fluxograma dos ensaios para verificação da influência de micronutrientes na nitrificação 


\subsection{INÓCULOS}

Nesta pesquisa, foi utilizado lodo de estação de tratamento de água residuária de indústria produtora de aminoácido, usado no tratamento de altas cargas de nitrogênio, (AJINOMOTO-Pederneiras - SP) como inóculo do RBS. O consórcio microbiano previamente enriquecido sob condições anammox foi inoculado no RLF e, após o estabelecimento da biomassa, foi misturado lodo ativado da indústria Volkswagen (São Carlos-SP) para formação de novo biofilme visando remoção de nitrogênio amoniacal. O lodo ativado também foi utilizado como inóculo para os ensaios de nitrificação nos quimiostatos.

\subsection{ENRIQUECIMENTO EM REATOR OPERADO EM BATELADA SEQUENCIAIS}

Esta configuração de reator em batelada sequencial foi escolhida para enriquecimento devido à sua eficiência em retenção de biomassa, que é condição fundamental nesta etapa, uma vez que microrganismos anammox têm elevado tempo de geração (STROUS et al., 1998).

O RBS (Figura 4) foi inoculado com 3L de lodo de indústria produtora de aminoácido (Ajinomoto-Pederneiras-SP).

O RBS foi instalado no interior de câmara com temperatura controlada a $37 \pm 1^{\circ} \mathrm{C}$ por um sistema de controle e medição de temperatura. $\mathrm{O}$ reator foi confeccionado em vidro borossilicato com volume total de $5 \mathrm{~L}$, operado em bateladas sequenciais, sendo construído nas seguintes dimensões: diâmetro interno $20,3 \mathrm{~cm}$ e altura $17 \mathrm{~cm}$. O reator foi submetido à $50 \mathrm{rpm}$ por sistema de agitação mecânica com propulsores tipo 3 pás planas de $13,5 \mathrm{~cm}$ de comprimento e $2 \mathrm{~cm}$ altura.

O tempo de sedimentação foi de 20 minutos, sendo descartado $3 \mathrm{~L}$ de efluente a cada batelada. A estratégia de alimentação, inicialmente durante 12 horas, foi adotada para se evitar acúmulo de nitrito no reator, que pode causar inibição do processo anammox (STROUS et al., 1999b), durante todo período de enchimento e reação foi fluxionado mistura gasosa comercial de $\mathrm{Ar} / \mathrm{CO}_{2}(97 / 3 \%)$. As estratégias abordadas estão apresentadas na Tabela 1. 
O RBS foi alimentado com meio basal (VAN DE GRAAF et al., 1996) descrito na Tabela 2, Tabela 3, Tabela 4. Durante os primeiros 32 dias de operação foi adicionado 1,4 mg N-N $\mathrm{N}_{2} / \mathrm{L}$ e $0,7 \mathrm{mg} \mathrm{N}-\mathrm{NH}_{2} \mathrm{OH} / \mathrm{L}$ para potencializar o enriquecimento, devido à natureza cíclica do mecanismo anammox, as células precisam investir poder redutor para iniciar seu catabolismo. Esta barreira energética pode ser superada pela adição direta de hidroxilamina $\left(\mathrm{NH}_{2} \mathrm{OH}\right)$ ou hidrazina $\left(\mathrm{N}_{2} \mathrm{H}_{4}\right)$ (STROUS et al., 1998).

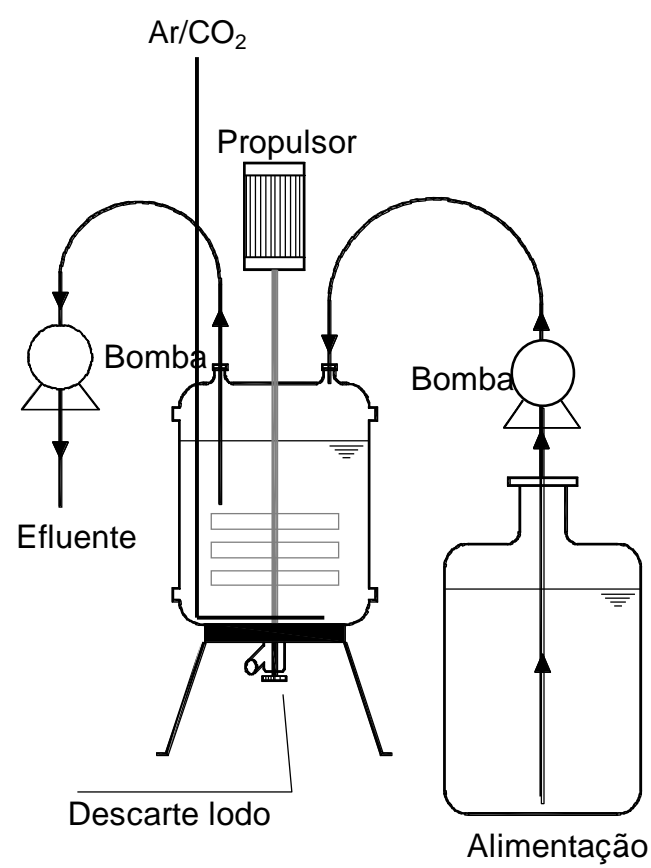

Figura 4. Esquema do reator operado em bateladas sequenciais 
Tabela 1. Etapas e duração de cada batelada

\begin{tabular}{|c|c|c|c|}
\hline Estratégia & Etapa & Tempo & Tempo de operação \\
\hline \multirow{5}{*}{ I } & $\begin{array}{l}\text { Enchimento } \\
\text { (alimentação) }\end{array}$ & $0-12 \mathrm{~h}$ & \multirow{5}{*}{$0-89^{\circ}$ dia } \\
\hline & Agitação & $0-55,5 \mathrm{~h}$ & \\
\hline & $\begin{array}{c}\text { Fluxo de mistura } \\
\text { gasosa } \\
(\text { Argônio/CO } \\
(97 \% / 3 \%)\end{array}$ & $0-55,5 \mathrm{~h}$ & \\
\hline & Sedimentação & $55,5-55,83 \mathrm{~h}$ & \\
\hline & Descarte & $55,83-56 h$ & \\
\hline \multirow[t]{2}{*}{ II } & $\begin{array}{l}\mathrm{O} \text { meio foi renovado } \\
\text { manualmente à } \\
\text { medida que os }\end{array}$ & & \multirow[t]{2}{*}{$90-120^{\circ}$ dia } \\
\hline & $\begin{array}{c}\text { substratos } \\
\text { nitrogenados eram } \\
\text { consumidos }\end{array}$ & & \\
\hline \multirow{5}{*}{ III } & $\begin{array}{l}\text { Enchimento } \\
\text { (alimentação) }\end{array}$ & $0-167,5 \mathrm{~h}$ & \multirow{5}{*}{$121-179^{\circ} \mathrm{dia}$} \\
\hline & Agitação & $0-167,5 \mathrm{~h}$ & \\
\hline & $\begin{array}{c}\text { Fluxo de mistura } \\
\text { gasosa } \\
(\text { Argônio/CO } \\
(97 \% / 3 \%)\end{array}$ & $0-167,5 \mathrm{~h}$ & \\
\hline & Sedimentação & $167,5-167,83 \mathrm{~h}$ & \\
\hline & Descarte & $167,83-168 \mathrm{~h}$ & \\
\hline \multirow{5}{*}{ IV } & $\begin{array}{l}\text { Enchimento } \\
\text { (alimentação) }\end{array}$ & $0-2,5 \mathrm{~h}$ & \multirow{5}{*}{$215-550^{\circ}$ dia } \\
\hline & Agitação & $0-23,5 \mathrm{~h}$ & \\
\hline & $\begin{array}{l}\text { Fluxo de mistura } \\
\text { gasosa } \\
\left.\text { (Arrgônio/CO } \mathrm{CO}_{2}\right) \\
(97 \% / 3 \%)\end{array}$ & $0-23,5 \mathrm{~h}$ & \\
\hline & Sedimentação & $23,5-23,83 \mathrm{~h}$ & \\
\hline & Descarte & $23,83-24 \mathrm{~h}$ & \\
\hline
\end{tabular}

Tabela 2. Composição do meio basal de cultivo

\begin{tabular}{cc}
\hline Componentes & Quantidades - q.s.p. 1000mL de água \\
\hline $\mathrm{NH}_{4} \mathrm{Cl}$ & Variável \\
$\mathrm{NaNO}_{2}$ & Variável \\
$\mathrm{KHCO}_{3}$ & $1000 \mathrm{mg}$ \\
$\mathrm{KH}_{2} \mathrm{PO}_{4}$ & $27,2 \mathrm{mg}$ \\
$\mathrm{MgSO}_{4} \cdot 7 \mathrm{H}_{2} \mathrm{O}$ & $300 \mathrm{mg}$ \\
$\mathrm{CaCl}_{2} \cdot 2 \mathrm{H}_{2} \mathrm{O}$ & $180 \mathrm{mg}$ \\
Solução traço I & $1 \mathrm{ml}$ \\
Solução traço II & $1 \mathrm{ml}$ \\
\hline
\end{tabular}

Fonte: Adaptado de (VAN DE GRAAF et al., 1996) 


\begin{tabular}{lc}
\hline \multicolumn{1}{c}{ Componentes } & Quantidades - q.s.p. 1000mL de água \\
\hline EDTA & $5 \mathrm{~g}$ \\
$\mathrm{FeSO}_{4} 7 \mathrm{H}_{2} \mathrm{O}$ & $9,17 \mathrm{~g}$ \\
\hline
\end{tabular}

Fonte: Adaptado de (VAN DE GRAAF et al., 1996)

Tabela 4. Composição da Solução Traço II

\begin{tabular}{cc}
\hline Componentes & Quantidades - q.s.p. 1000mL de água \\
\hline $\mathrm{EDTA}$ & $15 \mathrm{~g}$ \\
$\mathrm{ZnSO}$ & $0,73 \mathrm{~g}$ \\
$\mathrm{CoCl}_{2} \cdot 6 \mathrm{H}_{2} \mathrm{O}$ & $0,24 \mathrm{~g}$ \\
$\mathrm{MnCl}_{2} \cdot 4 \mathrm{H}_{2} \mathrm{O}$ & $0,99 \mathrm{~g}$ \\
$\mathrm{CuSO}_{4} \cdot 5 \mathrm{H}_{2} \mathrm{O}$ & $0,25 \mathrm{~g}$ \\
$\mathrm{NaMoO}_{4} \cdot 2 \mathrm{H}_{2} \mathrm{O}$ & $0,22 \mathrm{~g}$ \\
$\mathrm{NiCl}_{2} \cdot 6 \mathrm{H}_{2} \mathrm{O}$ & $0,19 \mathrm{~g}$ \\
$\mathrm{Na}_{2} \mathrm{SeO}_{3}$ & $0,09 \mathrm{~g}$ \\
$\mathrm{H}_{3} \mathrm{BO}_{3}$ & $0,014 \mathrm{~g}$ \\
\hline
\end{tabular}

Fonte: Adaptado de (VAN DE GRAAF et al., 1996)

\subsection{OPERAÇÃO DO REATOR DE LEITO FIXO}

A oxidação do amônio sob condições anammox e de microaerofilia foi testada em reator de leito fixo confeccionado em acrílico (RLF) com volume total de 4,440L, volume útil de 2,220L e dimensões de $78,5 \mathrm{~mm}$ de diâmetro por $800 \mathrm{~mm}$ de altura de leito preenchido com material suporte e $900 \mathrm{~mm}$ de altura total. As relação comprimento do leito/diâmetro (C/D) dos amostradores estão mostrados na Figura 5.

O RLF foi alimentado com meio basal (VAN DE GRAAF et al., 1996) descrito na Tabela 2,Tabela 3, Tabela 4, o TRH foi de 24 h controlado por bomba dosadora Gilson ${ }^{\mathrm{TM}}$. $\mathrm{O}$ reator foi instalado no interior de uma câmara com temperatura controlada a $37 \pm 1^{\circ} \mathrm{C}$ por um sistema de controle e medição de temperatura.

A imobilização da biomassa foi realizada por meio da recirculação do inóculo em circuito fechado durante quatro dias. A biomassa foi imobilizada em material suporte (refugo de polietileno de baixa densidade, PEBD) com diâmetro de partícula médio de $8 \mathrm{~mm}$. Foram adicionados $1753,4 \mathrm{~g}$ de PEBD de densidade de aproximadamente $0,79 \mathrm{~g} / \mathrm{mL}$. 


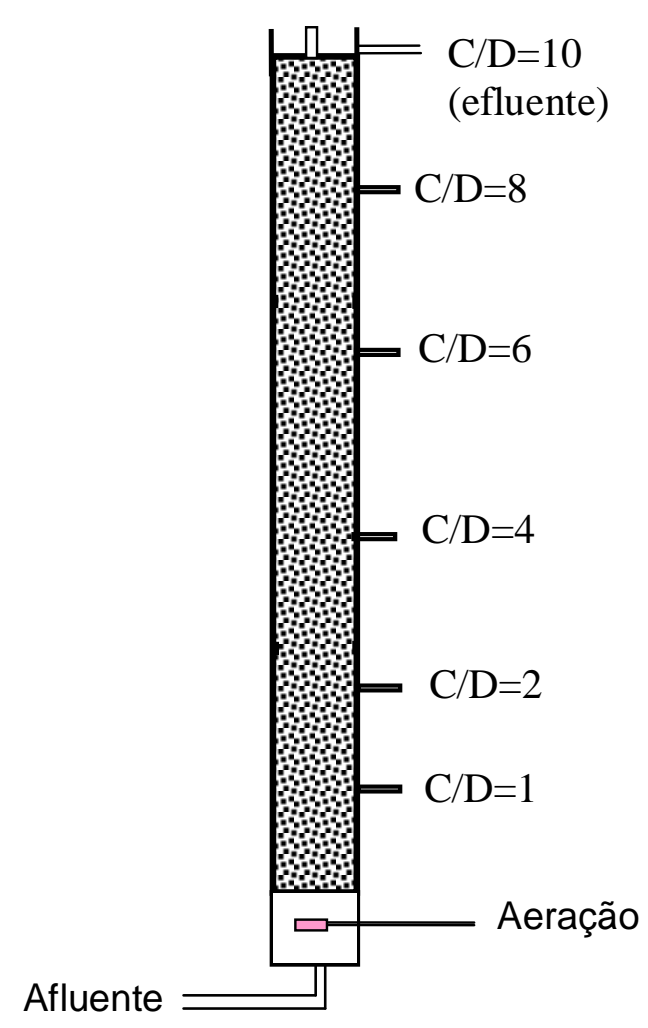

Figura 5. Esquema do reator de leito fixo

\subsection{ENSAIOS FISIOLÓGICOS DE ATIVIDADE ANAMMOX ESPECÍFICA}

Os ensaios fisiológicos de Atividade Anammox Específica (AAE) foram realizados em frascos de $250 \mathrm{~mL}$ de volume total preenchidos com $90 \mathrm{~mL}$ de meio de cultivo mais $10 \mathrm{ml}$ de biomassa anammox). Foi verificada a influência de alguns fatores na atividade anammox, conforme descrito na Tabela 5.

Os ensaios com variação de concentração dos compostos nitrogenados foram realizados em triplicata, os demais foram em duplicata, mantidos sem agitação e temperatura de $37^{\circ} \mathrm{C}$ ou conforme explicitada. Também foi realizado ensaio de atividade anammox específica (AAE) da biomassa submetida às concentrações iniciais próximas a relação estequiométrica anammox $\left({\mathrm{N}-\mathrm{NO}_{2}}^{-} / \mathrm{N}_{-} \mathrm{NH}_{4}{ }^{+}=1,38\right)$. A influência da agitação foi verificada em perfil temporal no próprio RBS.

A potência específica aplicada é função de vários parâmetros geométricos do propulsor [diâmetro (d) e altura (h)], do reator [diâmetro(D) e altura (H)], da velocidade de rotação $(\mathrm{N})$ e propriedades dos fluidos [densidade $(\rho)$ e viscosidade $(\mu)$ ]. O cálculo de energia consumida em função da frequiência de agitação $(\mathrm{N})$ foi realizado segundo ARROJO et al. (2006) (Eqs.9 e 10). 


$$
\begin{aligned}
& \mathrm{Ne}=f(\mathrm{Re}, d / D, H / D, \text { propulsor }) \\
& P=\operatorname{Ne} \rho \mathrm{N}^{3} \mathrm{~d}^{5}
\end{aligned}
$$

A cinética anammox foi ajustada sempre em ordem zero. O valor da AAE foi calculado como valor máximo de $\mathrm{k}$ da reta ajustada dos valores médios das concentrações de N (amoniacal, de nitrito e ambos) dividido pela concentração de biomassa (SSV), conforme equação 9.

$$
\mathrm{C}_{\mathrm{N}} / \mathrm{C}_{\mathrm{x}}=-\mathrm{k} \cdot\left(\mathrm{t}-\mathrm{t}_{0}\right)+\mathrm{C}_{\mathrm{N} 0} / \mathrm{C}_{\mathrm{x}}
$$

Sendo:

$\mathrm{C}_{\mathrm{N}} / \mathrm{C}_{\mathrm{x}}(\mathrm{mg} \mathrm{N} / \mathrm{gSSV})$ = concentração de nitrogênio por unidade de biomassa no tempo $\mathrm{t}$;

$\mathrm{k}=$ constante cinética de ordem zero (AAE);

\begin{tabular}{|c|c|c|}
\hline $\begin{array}{c}\text { Concentração de compostos } \\
\text { nitrogenados }\end{array}$ & $\begin{array}{c}\text { Temperatura } \\
\left(70 \mathrm{mg} \mathrm{N}^{-\mathrm{NH}_{4}}+/ 70 \mathrm{~N}-\mathrm{NO}_{2}{ }^{-}\right)\end{array}$ & Agitação \\
\hline $32,8 \mathrm{mg} \mathrm{N}^{-\mathrm{NH}_{4}}{ }^{+} / \mathrm{L} / 31,6 \mathrm{~N}^{-\mathrm{NO}_{2}}{ }^{-} / \mathrm{L}$ & $35^{\circ} \mathrm{C}$ & $50 \mathrm{rpm}$ \\
\hline 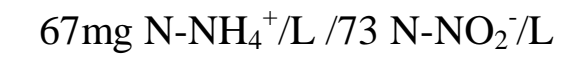 & $30^{\circ} \mathrm{C}$ & $80 \mathrm{rpm}$ \\
\hline $67,3 \mathrm{~N}^{-\mathrm{NH}_{4}}{ }^{+} / \mathrm{L} / 92,2 \mathrm{~N}-\mathrm{NO}_{2}^{-} / \mathrm{L}$ & $25^{\circ} \mathrm{C}$ & $100 \mathrm{rpm}$ \\
\hline & $20^{\circ} \mathrm{C}$ & $150 \mathrm{rpm}$ \\
\hline
\end{tabular}

$\mathrm{C}_{\mathrm{N} 0} / \mathrm{C}_{\mathrm{x}}=$ concentração inicial de nitrogênio por unidade de biomassa.

Tabela 5. Parâmetros analisados em ensaios de atividade anammox específica

\subsection{ENSAIO PARA VERIFICAÇÃo DA INFLUÊNCIA DE MICRONUTRIENTES NA NITRIFICAÇÃO}

A influência da adição de micronutrientes, em ambiente contendo biomassa nitrificante, foi estudada para verificar possível favorecimento da etapa de nitritação (formação de nitrito) em detrimento da nitratação (formação do nitrato). A nitritação é etapa fundamental para o processo de remoção de nitrogênio via anammox, uma vez que nitrito em conjunto com amônio são substratos para o processo de oxidação anaeróbia do amônio.

O inóculo utilizado nos quimiostatos nitrificantes foi obtido do tanque de aeração 
do sistema de lodos ativados da empresa Volkswagen-Brasil situado em São Carlos - SP.

Foram utilizados três quimiostatos com volume de $2.000 \mathrm{~mL}$ (Figura 6) para enriquecimento dos lodos. O volume útil foi de $1.540 \mathrm{~mL}$ de volume útil. A vazão afluente nos quimiostatos foi de $32 \mathrm{~mL} / \mathrm{h}$ e tempo de retenção hidráulica de 48 horas. Esse TRH foi escolhido para não influenciar na razão nitrito/nitrato, uma vez que os quimiostatos foram submetidos à temperatura de $35 \pm 1^{\circ} \mathrm{C}$ e com TRH de 1 dia, no qual as BNO poderiam ser lavadas do sistema e ocorrer acúmulo de nitrito em função de condições operacionais e não fisiológicas decorrente da adição ou não de micronutrientes, que foi a finalidade deste estudo.

Durantes os primeiros 73 dias os quimiostatos foram alimentados com

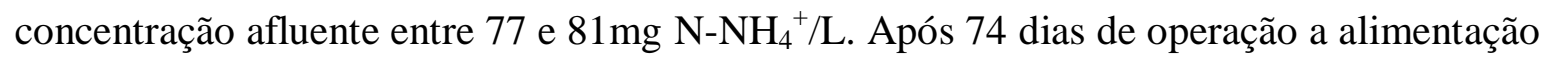
foi elevada para $180 \mathrm{mg} \mathrm{N}-\mathrm{NH}_{4}{ }^{+} / \mathrm{L}$ em média.

O meio de cultivo escolhido foi o descrito por VAN DE GRAAF et al. (1996) retirando-se o nitrito de sua composição conforme Tabelas 2, 3 e 4 anteriormente descritas. A solução traço I (Tabela 3) contendo o elemento Ferro foi adicionada nos três quimiostatos.

Um quimiostato foi alimentado com meio contendo solução traço II (Q1, quimiostato controle positivo), Q2 foi alimentado sem solução de micronutrientes (controle negativo) e Q3 foi alimentado inicialmente com solução de micronutrientes sem o elemento Boro (quimiostato experimental).

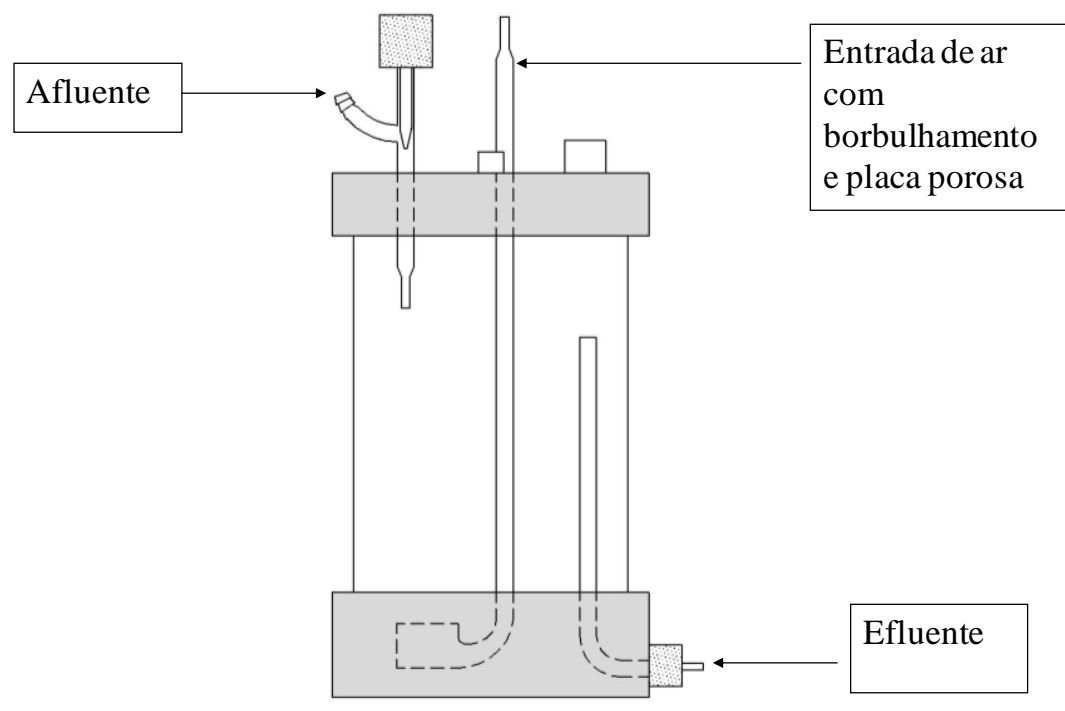

Figura 6. Esquema do quimiostato utilizado nos ensaios para verificação da influência de micronutrientes na nitrificação 
$\mathrm{O}$ pH afluente foi ajustado para 7,6-8 em toda alimentação. A concentração de oxigênio dissolvido foi mantida entre 4 e $5 \mathrm{mg}$ OD/L.

A verificação da influência dos micronutrientes nos quimiostatos nitrificantes foi realizada com os dados obtidos em relação à conversão de amônio quando os três quimiostatos operaram em estabilidade entre os dias 11 e 68.

Foi realizada análise de variância (ANOVA) com alfa de 0,05. Depois foi aplicada análise de Tukey para se verificar quais condições foram estatisticamente diferentes.

\subsection{ANÁLISES FÍSICO-QUÍMICAS}

As análises de amônio, nitrato e nitrito foram feitas pelos menos três vezes por semana usando injeção em fluxo (FIA) proposto pelo Standard Methods for the Examination of Water and Wastewater (APHA, 2005). O Apêndice - A apresenta algumas curvas de calibração do método FIA para compostos nitrogenados.

Análise de sólidos suspensos voláteis foi realizadas segundo Standard Methods for the Examination of Water and Wastewater (APHA, 2005).

$\mathrm{O}$ pH foi analisado utilizando aparelho Digimed modelo DM-21 com eletrodo combinado de platina Pt4805 da Mettler-Toledo. O pH foi analisado toda vez que meio de cultivo fresco foi submetido à alimentação.

A concentração de oxigênio dissolvido no reator de leito fixo (RLF) foi determinada utilizando-se aparelho ORION ${ }^{\circledR}$ modelo 810A+.

\subsection{ANÁLISE DE BIOLOGIA MOLECULAR}

Foram retiradas amostras para extração de DNA com 170 e 450 dias de operação do RBS, e com 139 dias de operação do RLF.

A extração do ácido nucléico foi realizada de acordo com o protocolo de NG et. al. (1994). A partir do DNA extraído das amostras, foi obtido produto de PCR do gene RNAr 16S utilizando primers universais 6F/1510R para o domínio Bacteria (SCHMID et al., 2000) e específico PLA 46/AMX 820R para anammox (EGLI et al., 2003). Foi utilizado termociclador Master cycle (Eppendorf) para amplificação dos fragmentos de DNA.

A eletroforese em gel de agarose foi realizada para avaliar o produto resultante da extração do ácido nucléico e da amplificação por PCR. Assim, para verificar o produto da extração do ácido nucléico foram usados géis de agarose $2 \%$ e High mass como marcador 
de elevada massa molecular. Para avaliar o produto da amplificação por PCR foram usados géis de agarose $1 \%$ e Low mass como marcador de baixa massa molecular.

O produto de PCR foi inserido no vetor TOPO TA Cloning ${ }^{\circledR}$ e, imediatamente, feita a transformação. O protocolo para preparação do "Minipreps" para a clonagem está descrito a seguir: (a) realizar PCR com primers descritos anteriormente, (b) verificar o produto da amplificação do fragmento de interesse em gel de agarose 1\%, (c) preparar o mix de reação para adição de adeninas (A) e incubar a $72^{\circ} \mathrm{C}$, por 15 minutos, (d) preparar para reação de ligação, incubar por 30 minutos em temperatura ambiente $\left( \pm 23^{\circ} \mathrm{C}\right)$, transferir os tubos para banho de gelo e fazer a transformação imediatamente; (e) realizar a transformação no fluxo laminar adicionando $4,0 \mu \mathrm{L}$ do produto da ligação junto com células competentes (E. coli DH $5 \alpha$ ) e misturar com a ponta da pipeta, incubar por 20 minutos no gelo; colocar a $42^{\circ} \mathrm{C}$, por 2 minutos, sem agitação; misturar $250 \mu \mathrm{L}$ do meio S.O.C do kit (aquecido previamente a $42^{\circ} \mathrm{C}$ em banho-maria) mais o material transformado no fluxo; agitar por 30 minutos, mantendo a temperatura de $37^{\circ} \mathrm{C}$; (f) preparar as placas contendo meio LB sólido, adicionando os reagentes específicos. O seqüenciamento foi realizado no seqüenciador ABI PRISM 310.

As sequências obtidas foram alinhadas no ClustalX2 (LARKIN et al., 2007), e a matriz de distância gerada no PHYLIP utilizada no programa DOTUR (SCHLOSS \& HANDELSMAN, 2005) para gerar Unidades Taxonômicas operacionais (UTOs) com nível de similaridade de $97 \%$ para sequências geradas por primer universal, e 99\% para sequências utilizando primer especifico. Na construção das árvores filogenéticas, as UTOs obtidas foram alinhadas em NAST e comparadas com as seqüências do banco de dados GreenGenes (DESANTIS et al., 2006). As árvores foram construídas utilizando o programa ARB (regiões com alta variação de segmentos do gene RNAr foram omitidas usando filtro lanemaskPH) (LUDWIG et al., 2004).

\subsection{EXAMES MICROSCÓPICOS}

Exames microscópicos foram realizados em microscopia óptica comum, de contraste de fase e epifluorescência utilizando Microscópio Olympus BX60, acoplado a câmera com captura de imagem e software Image-Pro Plus. 


\section{ReSUlTAdos E DiscuSSÃo}

\subsection{OPERAÇÃO DOS QUIMIOSTATOS PARA VERIFICAR A INFLUÊNCIA DE MICRONUTRIENTES NA NITRIFICAÇÃO}

O quimiostato controle positivo com solução de micronutrientes (Q1) atingiu estabilidade com 11 dias de operação apresentou conversão média de nitrogênio amoniacal de $99 \pm 1,5 \%$ entre os dias 11 e 68, para concentração média de $82,2 \mathrm{mg} \mathrm{N}-\mathrm{NH}_{4}{ }^{+} / \mathrm{L}$. O quimiostato experimental Q2 (sem adição de micronutrientes - controle negativo), no mesmo período, obteve eficiência de $94,5 \pm 6,4 \%$ e Q3 (com solução de micronutriente retirando-se o Boro) conversão de 93,3 $\pm 7,3 \%$ do nitrogênio amoniacal, para concentrações afluentes de 78,9 e 78,7 $\mathrm{mg} \mathrm{N}^{-\mathrm{NH}_{4}}{ }^{+} / \mathrm{L}$.

A concentração de amônio afluente foi elevada após 70 dias de operação, por que as remoções nos três quimiostatos eram muito próximas, então foi decidido aumentar a carga nitrogenada para em média $180 \mathrm{mg} \mathrm{N}-\mathrm{NH}_{4}{ }^{+} / \mathrm{L}$ nas três condições (Figura 7, Figura 8 e Figura 9).

NOCKO e FORESTI (2007) verificaram que a nitrificação em sistema nitrificantedesnitrificante com biomassa imobilizada diminuiu de eficiência após 15 dias de operação alimentados com $100 \mathrm{mg} \mathrm{N}-\mathrm{NH}_{4}{ }^{+} / \mathrm{L}$. Após esta diminuição, a alimentação foi suplementada com as soluções I e II (VAN DE GRAAF et al., 1996) e, rapidamente a eficiência de nitrificação atingiu patamares próximos a 100\%.

Todos os quimiostatos deste trabalho foram alimentados com solução traço I contendo ferro em sua composição. Os quimiostatos foram operados em condições aeróbias e os citocromos, presentes na cadeia transportadora de elétrons de bactérias aeróbias, como Nitrosomonas sp. e Nitrospira sp., necessitam de ferro em sua composição.

Vale a pena ressaltar que, neste trabalho, o quimiostato Q2 apesar de não ser alimentado com a solução II de micronutrientes, sempre foi alimentado com a solução I contendo Ferro. NOCKO e FORESTI (2007) também adicionaram as soluções I e II ao mesmo tempo no reator de leito móvel visando à remoção de nitrogênio e carbono. 
Segundo os autores, essa adição favoreceu sobremaneira a conversão de amônio em nitrato. Assim, o desempenho de Q2, muito próximo aos desempenhos dos outros quimiostatos foi devido à presença do ferro na composição da solução de micronutrientes.

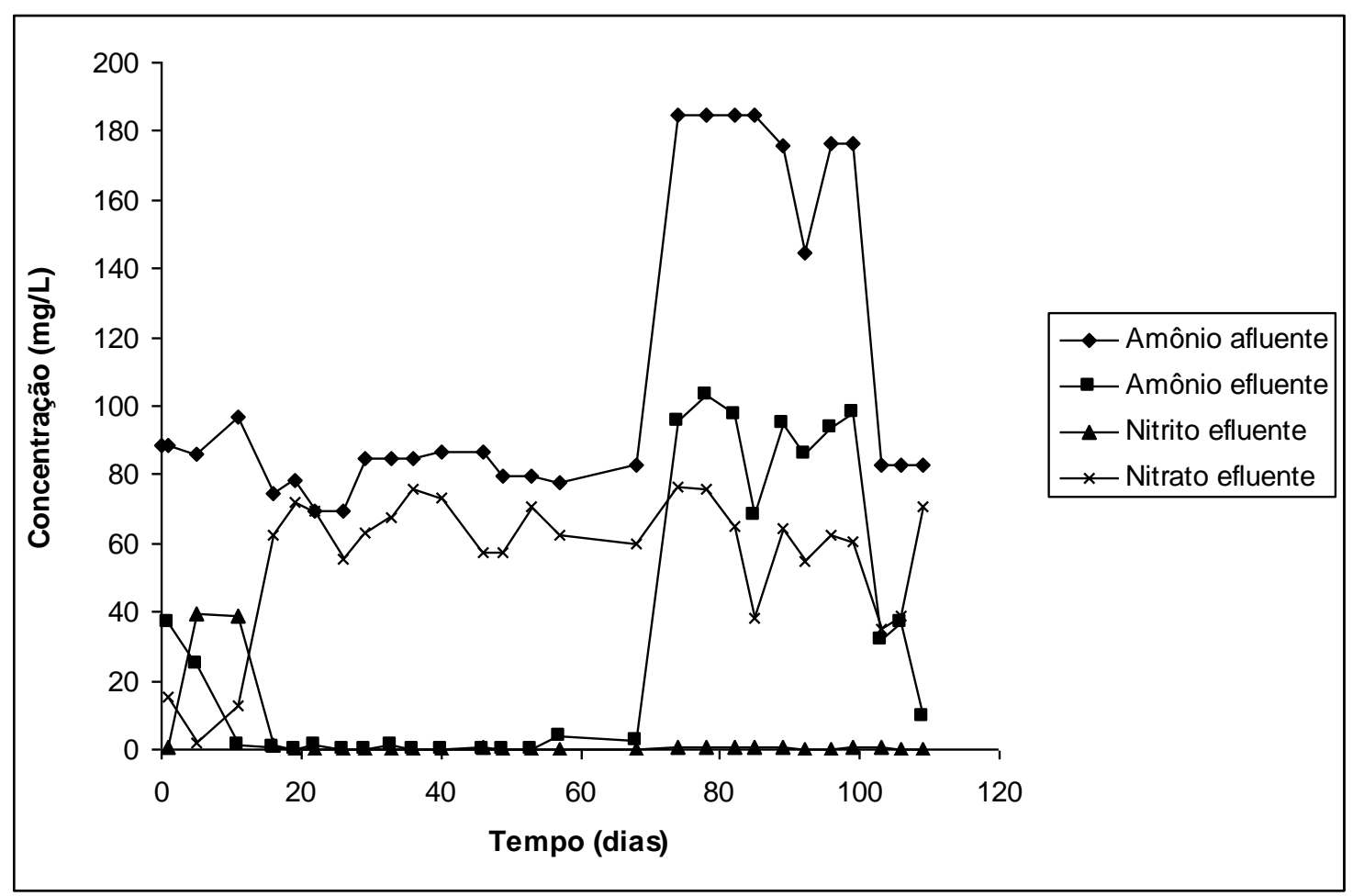

Figura 7. Variação temporal da concentração das formas nitrogenadas em Q1

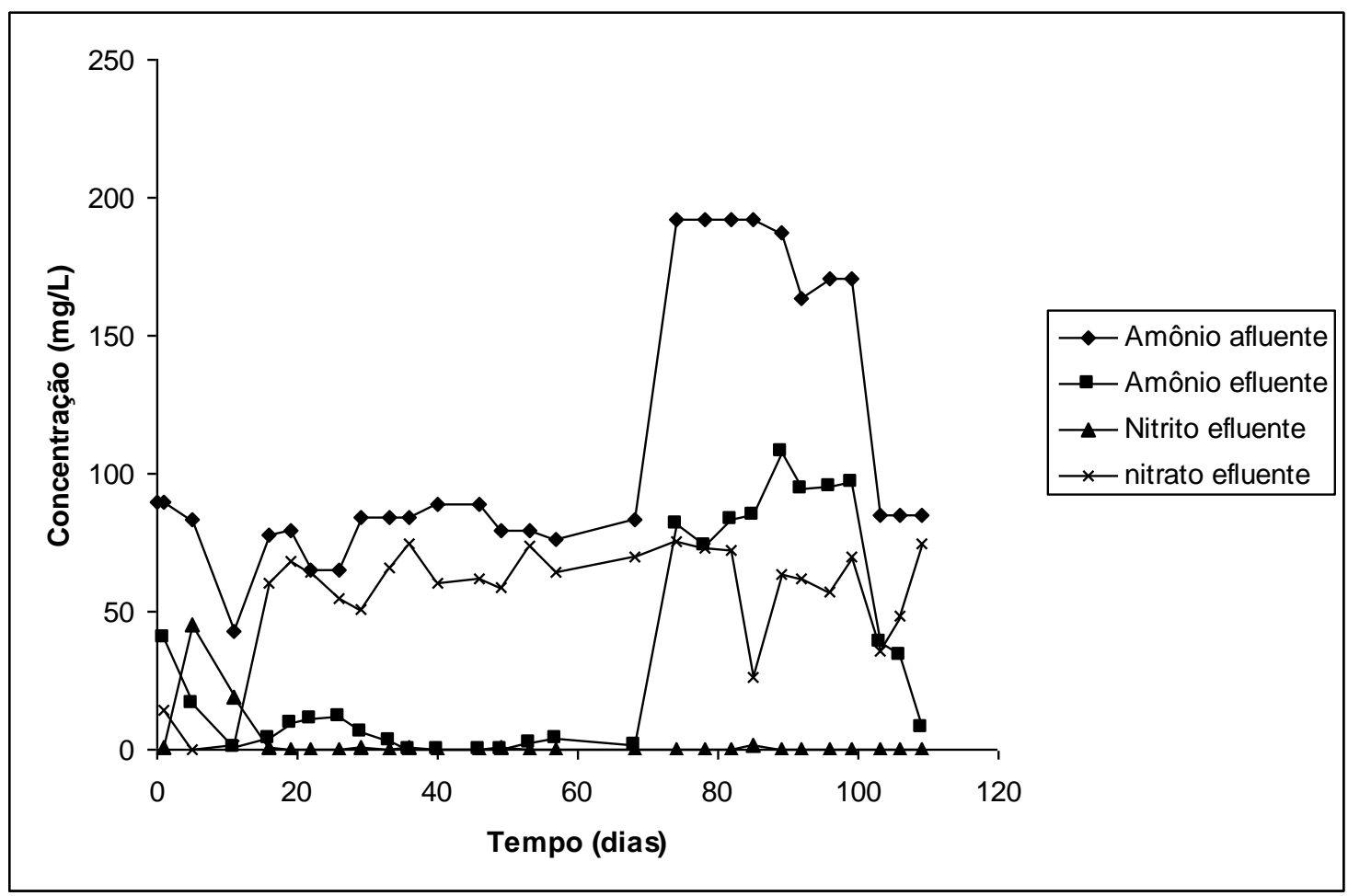

Figura 8. Variação temporal da concentração das formas nitrogenadas em Q2 


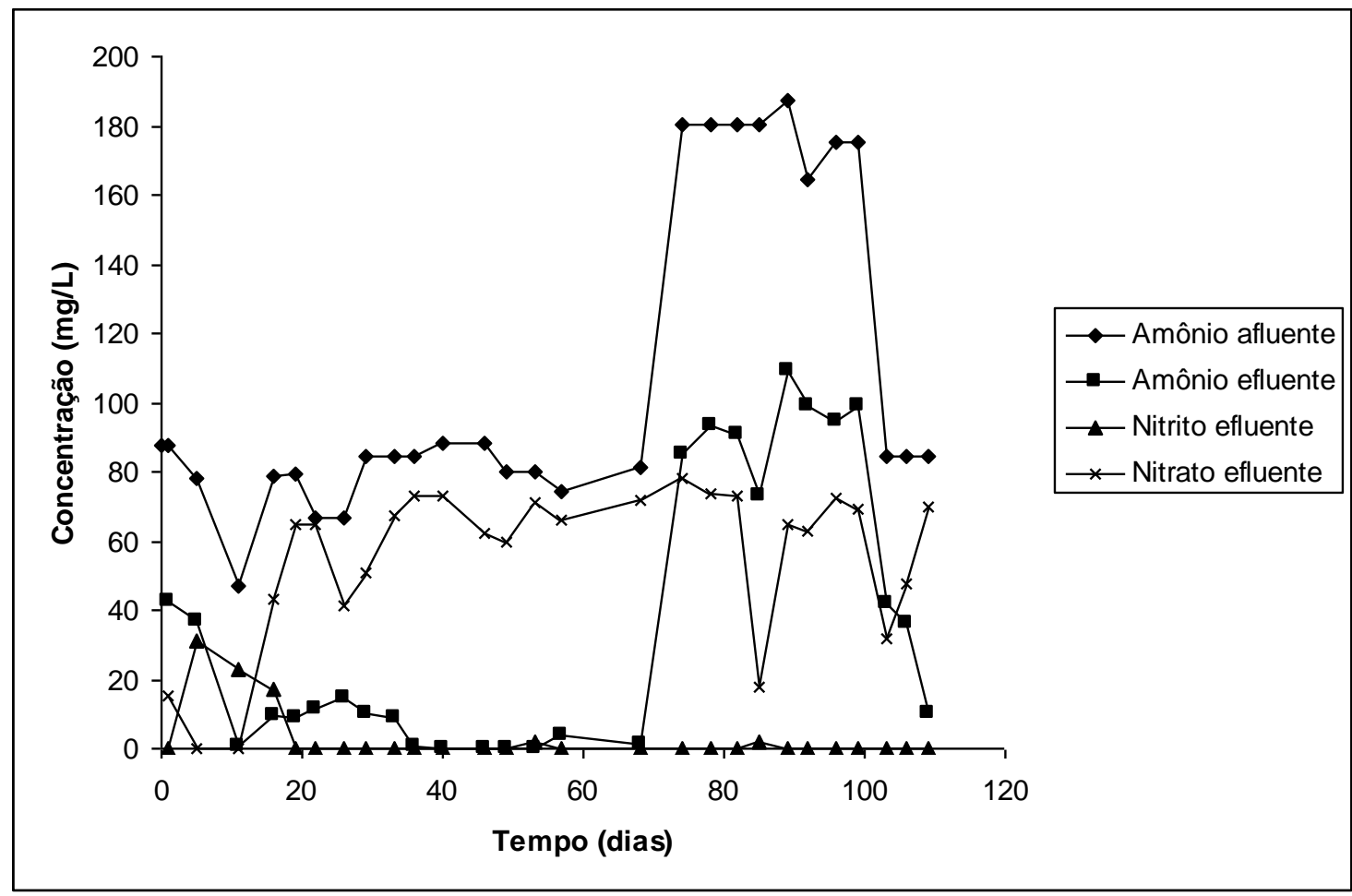

Figura 9. Variação temporal da concentração das formas nitrogenadas em Q3

Aparentemente, não houve diferença entre os três quimiostatos em relação à remoção de nitrogênio amoniacal (Figura 10). No entanto, aplicando-se a análise de variância (ANOVA) verificou-se diferença entre as três condições estudadas, entre os dias 11 e 69, em que as remoções se mantiveram estáveis (Apêndice - B).

Como foi verificada diferença entre as três condições, foi realizado teste de Tukey para saber quais condições eram diferentes. Portanto, em termos de conversão de amônio Q1 foi igual Q3 e os dois foram diferentes de Q2 (quimiostato controle negativo).

Quando os quimiostatos foram alimentados com concentração afluente de aproximadamente $180 \mathrm{mg} \mathrm{N}^{-\mathrm{NH}_{4}}{ }^{+} / \mathrm{L}$, as remoções médias foram de 47,5\%, 50,4\% e 47,7\%, para Q1, Q2 e Q3, respectivamente. Por meio da análise de variância foram considerados estatisticamente iguais. 


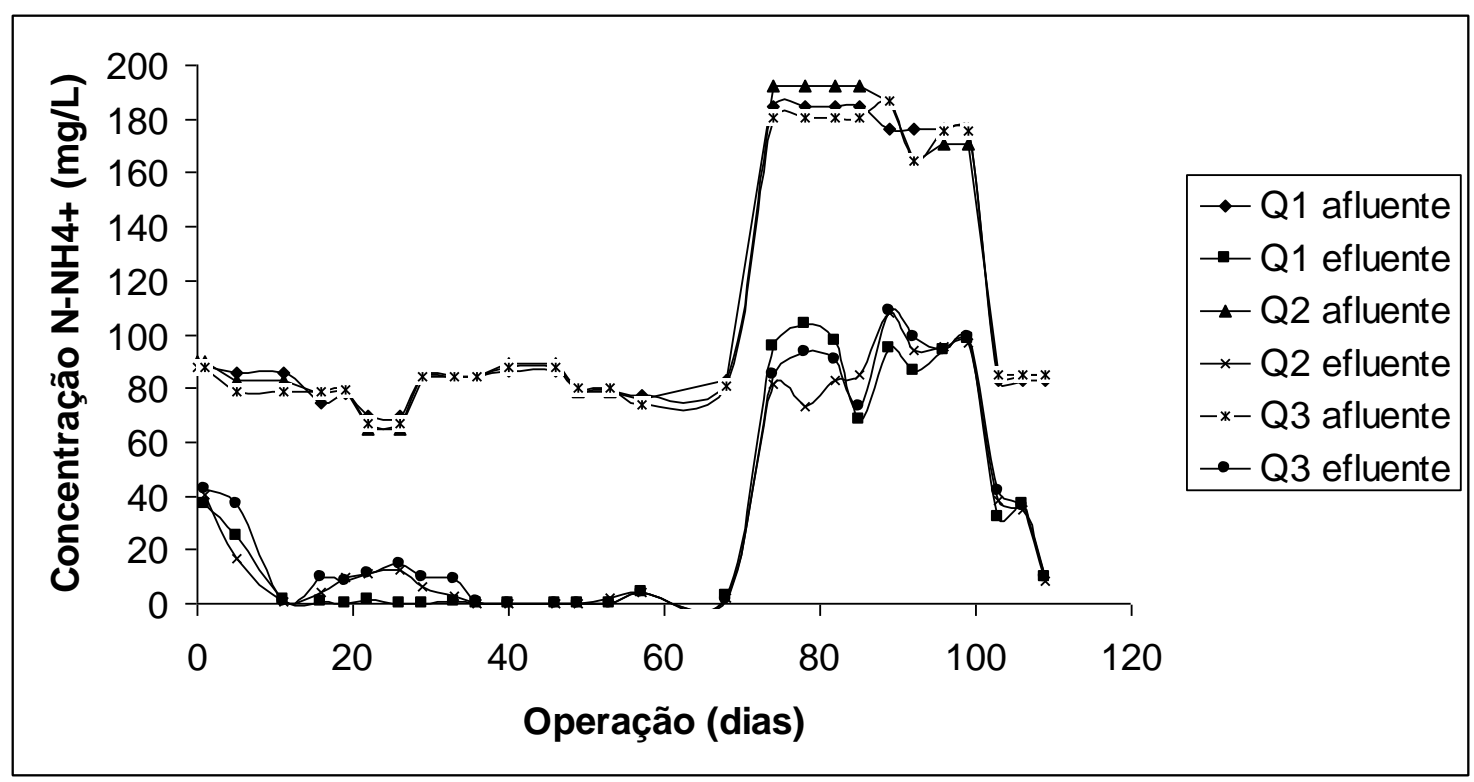

Figura 10. Variação temporal da concentração de amônio nos quimiostatos nitrificantes

Apesar de constatada diferença entre os tratamentos por meio do teste ANOVA e Tukey, do ponto de vista biotecnológico esta diferença não foi significativa por que a adição de micronutrientes gera custos ao processo de remoção de nitrogênio que não compensam o custo pelo benefício, pelo menos nas condições aqui testadas.

Não foi verificado favorecimento da nitritação em relação à nitratação em nenhuma das condições testadas, sendo que o produto principal foi nitrato. Portanto, os micronutrientes não influenciaram, nestas condições, na relação nitrito/nitrato efluente.

Quanto às análises de sólidos, os quimiostatos apresentaram diminuição dos valores em função do tempo de operação, 46,1; 49,3 e 40,4\% para Q1, Q2 e Q3, respectivamente (

Tabela 6). No entanto, devido ao erro do método de determinação de sólidos, não se pode dizer que Q3 apresentou maior perda de sólidos.

As análises com 19 dias de operação foram realizadas com amostra efluente, em que se observa que o sistema apesar de ocorrer mistura dos substratos presentes no meio líquido, a biomassa não se apresentava homogênea como revela a análise do dia 19, além disso, visualmente havia concentração de biomassa no fundo dos quimiostatos. 
Tabela 6. Valores de sólidos totais voláteis (g STV/L) nos diferentes quimiostatos

\begin{tabular}{cccc}
\hline $\begin{array}{c}\text { Operação } \\
\text { (dias) }\end{array}$ & $\begin{array}{c}\text { Q1 } \\
\text { (g STV/L) }\end{array}$ & $\begin{array}{c}\text { Q2 } \\
\text { (g STV/L) }\end{array}$ & $\begin{array}{c}\text { Q3 } \\
\text { (g STV/L) }\end{array}$ \\
\hline 0 & 1,67 & 1,57 & 1,62 \\
19 & 0,06 & 0,06 & 0,06 \\
109 & 0,9 & 0,795 & 0,965 \\
\hline $\begin{array}{c}\text { Diminuição } \\
(\%)\end{array}$ & 46,1 & 49,3 & 40,4 \\
\hline
\end{tabular}




\subsection{REATOR OPERADO EM BATELADAS SEQUENCIAIS}

\subsubsection{Enriquecimento}

O reator em bateladas sequenciais foi operado durante 550 dias. Nos primeiros 45 dias de operação, foi fluxionado Argônio $(99,95 \%)$ no meio líquido do reator. Nesse período, o pH efluente foi de até 9,1 (Figura 11). Tal valor era inadequado para enriquecer bactérias anammox, cujo valor de $\mathrm{pH}$ favorável para crescimento é de 8. Portanto, após esses 45 dias iniciais de operação, substitui-se o Argônio (99,95\%) pela mistura Argônio/ $\mathrm{CO}_{2}(97 / 3 \%)$ com a finalidade de se controlar o pH. Sob essa nova condição, os valores de $\mathrm{pH}$ mantiveram-se entre 7,4 e 7,7.

As concentrações afluentes médias dos compostos nitrogenados, durante os primeiros 55 dias, foram de 76,9 $\mathrm{mg}$ de $\mathrm{N}-\mathrm{NH}_{4}{ }^{+} / \mathrm{L}$ e 72,2 $\mathrm{mg}$ de $\mathrm{N}-\mathrm{NO}_{2}{ }^{-} / \mathrm{L}$. Desse modo, após 56 dias, de operação a concentração afluente dos compostos nitrogenados foi reduzida aproximadamente pela metade para evitar possível inibição pela concentração de nitrito. Após 60 dias de operação, pode-se observar a remoção de amônio no reator, para concentração afluente de $36 \mathrm{mg}$ de $\mathrm{N}^{-N_{4}}{ }_{4}{ }^{+} / \mathrm{L}$ e $32,7 \mathrm{mg}$ de $\mathrm{N}-\mathrm{NO}_{2}{ }^{-} / \mathrm{L}$. Todavia, nesse período, não foi observado remoção de nitrito (Figura 11).

No $80^{\circ}$ dia, de operação foi realizada análise de sulfato para verificar se estaria ocorrendo o processo suramox (sulfate reduction/ ammonium oxidation) (FDZ-POLANCO et al., 2001). A concentração de sulfato afluente era de 104,7mg $\mathrm{SO}_{4}{ }^{-} / \mathrm{L}$ e $106,13 \mathrm{mg} \mathrm{S_{4 }}{ }^{-}$ /L efluente, portanto o processo suramox foi descartado.

No $89^{\circ}$ dia foi realizado perfil temporal das concentrações dos compostos nitrogenados dentro do reator (Tabela 7). Pôde-se observar que ocorreu nitrificação no reator. Nesta etapa, o reator era alimentado durante 12 horas, a concentração de amônio permaneceu relativamente constante (em torno de $14 \mathrm{mg}$ de $\mathrm{N}-\mathrm{NH}_{4}{ }^{+} / \mathrm{L}$ ) e a concentração de nitrito aumentou até a $14^{\mathrm{a}}$ hora de 26,6 para 33,2 $\mathrm{mg}$ de $\mathrm{N}-\mathrm{NO}_{2}{ }^{-} / \mathrm{L}$.

Deste fato, foi inferido que, durante o descarte do efluente, estava entrando oxigênio no headspace do reator e, portanto, favorecendo a nitrificação nas primeiras horas do ciclo. Provavelmente, o processo anammox iniciou-se após todo consumo do oxigênio dissolvido, uma vez que 2,2 $\mathrm{mg}$ de $\mathrm{N}-\mathrm{NH}_{4}{ }^{+} / \mathrm{L}$ e 3,7 $\mathrm{mg}$ de $\mathrm{N}-\mathrm{NO}_{2}{ }^{-} / \mathrm{L}$ foram removidos até o final do ciclo.

Portanto, começou a ser fluxionado Argônio/ $\mathrm{CO}_{2}$ (97/3\%) no headspace do reator 
continuamente para evitar a entrada de oxigênio, e deu-se o início da segunda estratégia. $\mathrm{O}$ processo de oxidação anaeróbia do amônio havia começado.

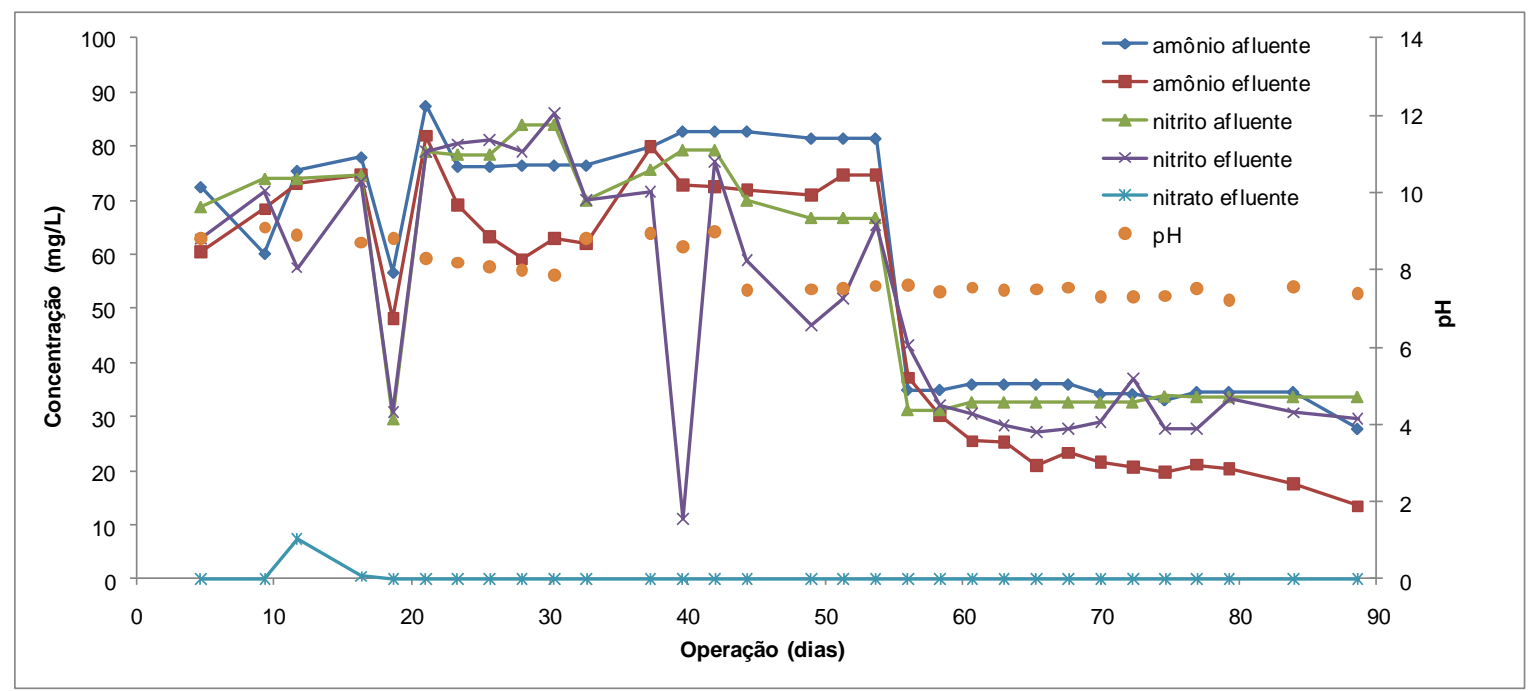

Figura 11. Variação dos compostos nitrogenados e pH durante a estratégia I de enriquecimento

Tabela 7. Variação temporal da batelada 38 ( $89^{\circ}$ dia de operação)

\begin{tabular}{ccc}
\hline $\begin{array}{c}\text { Tempo } \\
(\mathrm{h})\end{array}$ & $\begin{array}{c}\text { Nitrito } \\
\left(\mathrm{mg} \mathrm{N}^{-} \mathrm{NO}_{2}{ }^{-} / \mathrm{L}\right)\end{array}$ & $\begin{array}{c}\text { Amônio } \\
\left(\mathrm{mg} \mathrm{N}^{-} \mathrm{NH}_{4}{ }^{+} / \mathrm{L}\right)\end{array}$ \\
\hline 0 & 26,6 & 16,0 \\
1 & 26,5 & 14,8 \\
2 & 25,2 & 13,8 \\
3 & 27,9 & 15,0 \\
4 & 28,4 & 13,8 \\
5 & 29,2 & 13,3 \\
6 & 29,7 & 13,8 \\
7 & 25,2 & 13,9 \\
8 & 30,1 & 14,2 \\
9 & 29,0 & 14,3 \\
14 & 33,2 & 14,6 \\
26 & 30,3 & 13,8 \\
29,5 & 31,0 & 13,7 \\
32 & 31,5 & 12,7 \\
54 & 29,5 & 12,4 \\
\hline
\end{tabular}


Na estratégia II, o reator passou a ser operado sem tempo pré-determinado, ou seja, o reator foi alimentado cada vez que a concentração de amônio alcançava valores próximos de zero. As concentrações de amônio e de nitrito alcançaram valores próximos de zero após 10 dias. Nessa fase, as concentrações eram aproximadamente de 27,2 mg de $\mathrm{N}^{-\mathrm{NO}_{2}}{ }^{-}$ /L e 32,1 mg de $\mathrm{N}-\mathrm{NH}_{4}{ }^{+} / \mathrm{L}$. Na segunda alimentação, os compostos nitrogenados foram consumidos em seis dias, para as mesmas concentrações. Nas bateladas seguintes, a duração foi de aproximadamente dois dias, mesmo quando as concentrações foram elevadas para $80 \mathrm{mg}$ de $\mathrm{N}-\mathrm{NO}_{2}{ }^{-} / \mathrm{Le}$ e $70 \mathrm{mg}$ de $\mathrm{N}-\mathrm{NH}_{4}{ }^{+} / \mathrm{L}$ (Figura 12).

DAPENA-MORA et al. (2004b) observaram atividade anammox em lodo ativado após 60 dias de partida, em RBS a $50 \mathrm{rpm}$, pelo consumo estequiométrico de amônio e nitrito. O reator obteve eficiência de $82 \%$ para carga nitrogenada aplicada (CNA) de 1,4 $\mathrm{gN} / \mathrm{m}^{3}$ dia após 180 dias.

LOPEZ et al. (2008) utilizaram mistura de lodos ativados de estação de tratamento de esgoto e de tratamento de lixiviado para enriquecimento em RBS. Foi detectada a presença de bactérias anammox após 60 dias de operação, mas a atividade anammox somente foi detectada após 78 dias, com consumo de 53\% de amônio e 56\% de nitrito, para respectivamente, $21,9 \mathrm{mg}$ de $\mathrm{N}-\mathrm{NH}_{4}{ }^{+} / \mathrm{L}$ e 22,2 $\mathrm{mg}$ de N-NO${ }_{2}{ }^{-} / \mathrm{L}$. A hibridização com sonda fluorescente específica (FISH) foi positiva somente após 152 dias do início do enriquecimento.

THIRD et al. (2005) utilizaram hidrazina e hidroxilamina (intermediários anammox) no enriquecimento de biomassa anammox. Os autores alimentaram RBS com amônio, nitrato (para evitar inibição pelo nitrito), hidroxilamina e hidrazina e, após 47 dias, foi detectado consumo de amônio. A partir deste dia os intermediários foram retirados e o nitrato foi substituído pelo nitrito. A atividade anammox foi detectada após 105 dias.

Diferentes inóculos foram utilizados separadamente no enriquecimento de bactérias anammox em RBS operado a $33^{\circ} \mathrm{C}$ : lodo de UASB (L1), lodo ativado (L2) e lodo de digestor anaeróbio (L3). A remoção de aproximadamente $90 \%$ do nitrito afluente (50mg $\mathrm{N}-\mathrm{NO}_{2}{ }^{-} / \mathrm{L}$ ) ocorreu após 121, 106 e 100 dias para L1, L2 e L3, respectivamente (CHAMCHOI \& NITISORAVUT, 2007). 


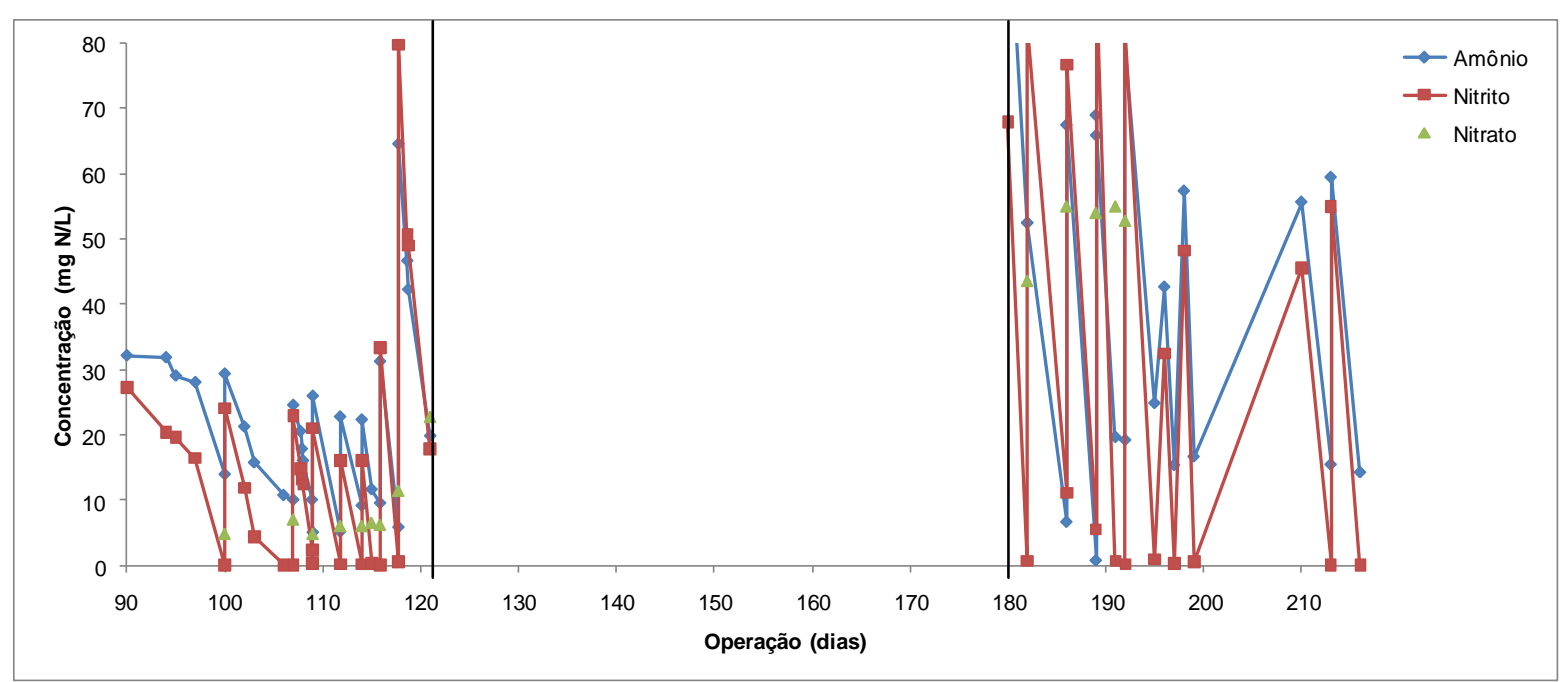

Figura 12. Variação dos compostos nitrogenados durante a estratégia II de enriquecimento

$\mathrm{Na}$ estratégia III (Figura 13) houve aumento da concentração de nitrito e amônio afluente, aproximadamente $210 \mathrm{mg}$ de $\mathrm{N}_{-} \mathrm{NO}_{2}{ }^{-} / \mathrm{L}$ e $210 \mathrm{mg}$ de $\mathrm{N}-\mathrm{NH}_{4}{ }^{+} / \mathrm{L}$, com tempo de ciclo de sete dias. A finalidade desta estratégia foi favorecer o aumento da concentração da biomassa, pois, nesta forma de alimentação a biomassa, está sempre em contato com meio fresco. No entanto, não foi verificado aumento da biomassa conforme mostra a Figura 14. Ao contrário, a concentração da biomassa decresceu de 1,03 g SSV/L com 132 dias de operação para 0,55 g SSV/L com 177 dias de operação. Por este motivo, a estratégia II foi retomada e, portanto, e foram adicionados aproximadamente $80 \mathrm{mg}$ de $\mathrm{N}-\mathrm{NO}_{2}{ }^{-} / \mathrm{Le} \mathrm{e}^{-10 \mathrm{mg}} \mathrm{de}$ $\mathrm{N}-\mathrm{NH}_{4}{ }^{+} / \mathrm{L}$ (Figura 12).

Durante esta estratégia as concentrações dos compostos nitrogenados foram aproximadamente equimolares, e em decorrência deste fato o efluente apresentou amônio residual, pois na equação anammox 1,32 mol de $\mathrm{N}_{-} \mathrm{NO}_{2}{ }^{-}$é consumido para cada 1 mol de $\mathrm{N}-\mathrm{NH}_{4}{ }^{+}$(Eq. 7). 


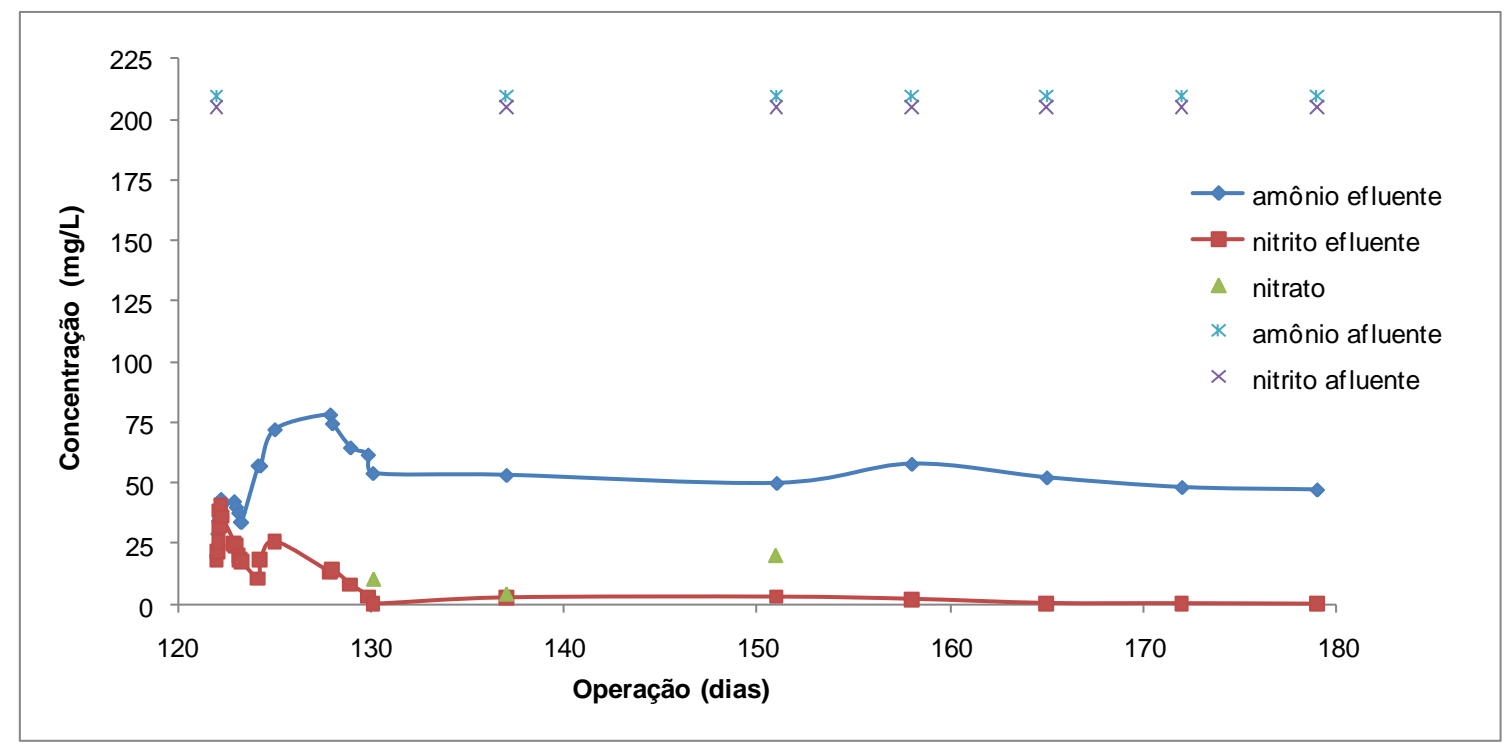

Figura 13. Variação dos compostos nitrogenados durante a estratégia III de enriquecimento

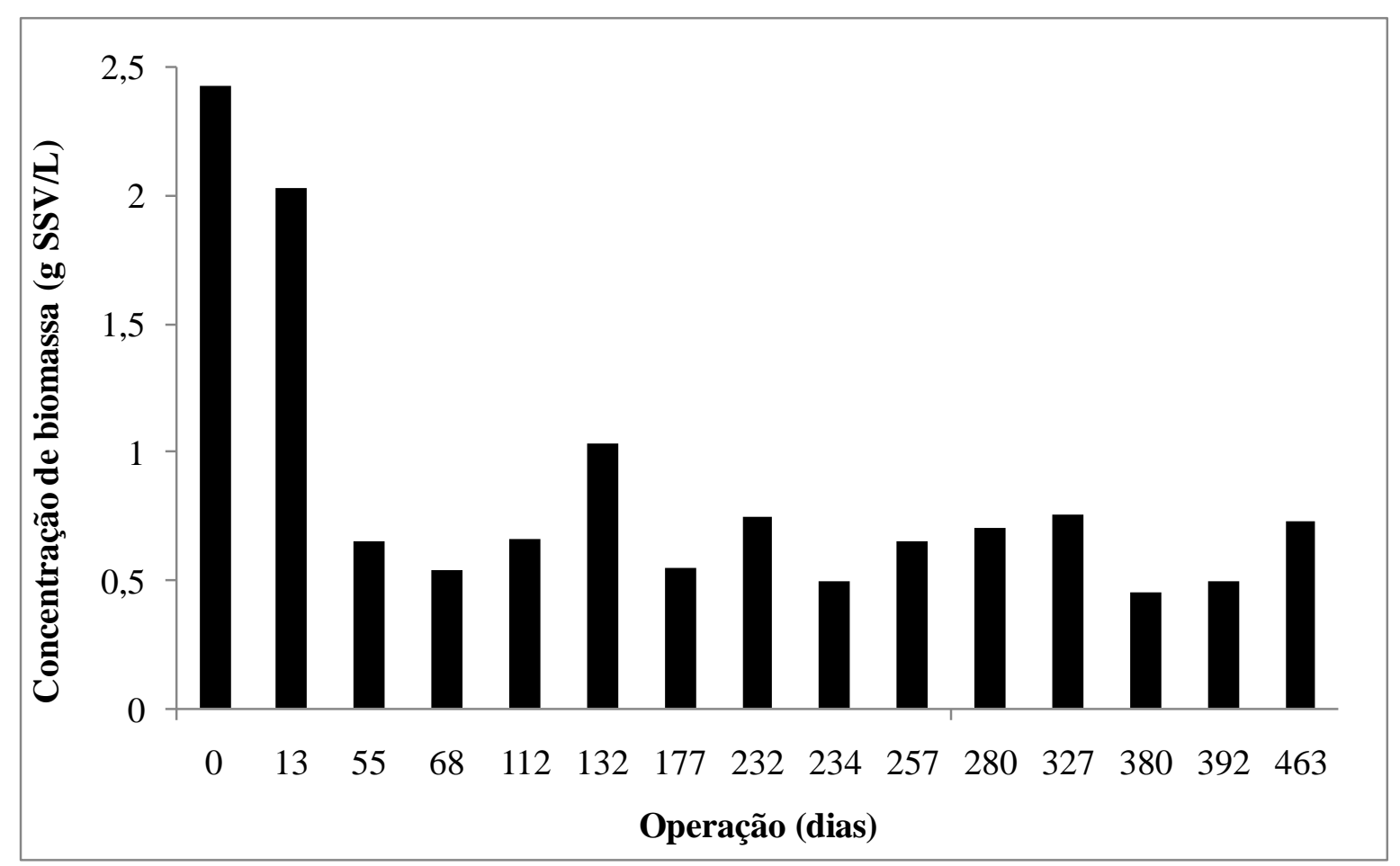

Figura 14. Variação da concentração de biomassa (SSV) no reator

O fim da segunda parte da estratégia II foi determinado como o fim do período de enriquecimento (partida) do reator. Portanto, foi possível corroborar a primeira parte da hipótese desta tese: foi possível obter biomassa anammox a partir de lodo nitrificantedesnitrificante. 


\subsubsection{Operação do RBS com Ciclos de 24 Horas}

A estratégia IV teve seu início com 215 dias de operação. Na estratégia IV, o tempo de enchimento do reator foi de 2,5 horas com ciclos de 24 horas. A carga nitrogenada aplicada (CNA) no RBS foi elevada em oito concentrações diferentes (Tabela 8) de 155g de $\mathrm{N}\left(\mathrm{N}_{-} \mathrm{NO}_{2}{ }^{-}+\mathrm{N}-\mathrm{NH}_{4}{ }^{+}\right) / \mathrm{m}^{3}$ dia a $1.405,7 \mathrm{~g} \mathrm{~N} / \mathrm{m}^{3}$ dia, com eficiências médias de conversão de nitrogênio de 91,7 \% e 98,5\%, respectivamente (Figura 15).

Tabela 8. Etapas de operação durante a estratégia IV

\begin{tabular}{|ccccccccc|}
\hline Etapa & 1 & 2 & 3 & 4 & 5 & 6 & 7 & 8 \\
\hline $\begin{array}{l}\text { CNA média } \\
\left(\mathrm{g} \mathrm{N} / \mathrm{m}^{3} \text { dia }\right)\end{array}$ & 155,1 & 313,6 & 458,2 & 505,9 & 618,5 & 728,4 & 803,6 & 1405,7 \\
\hline
\end{tabular}




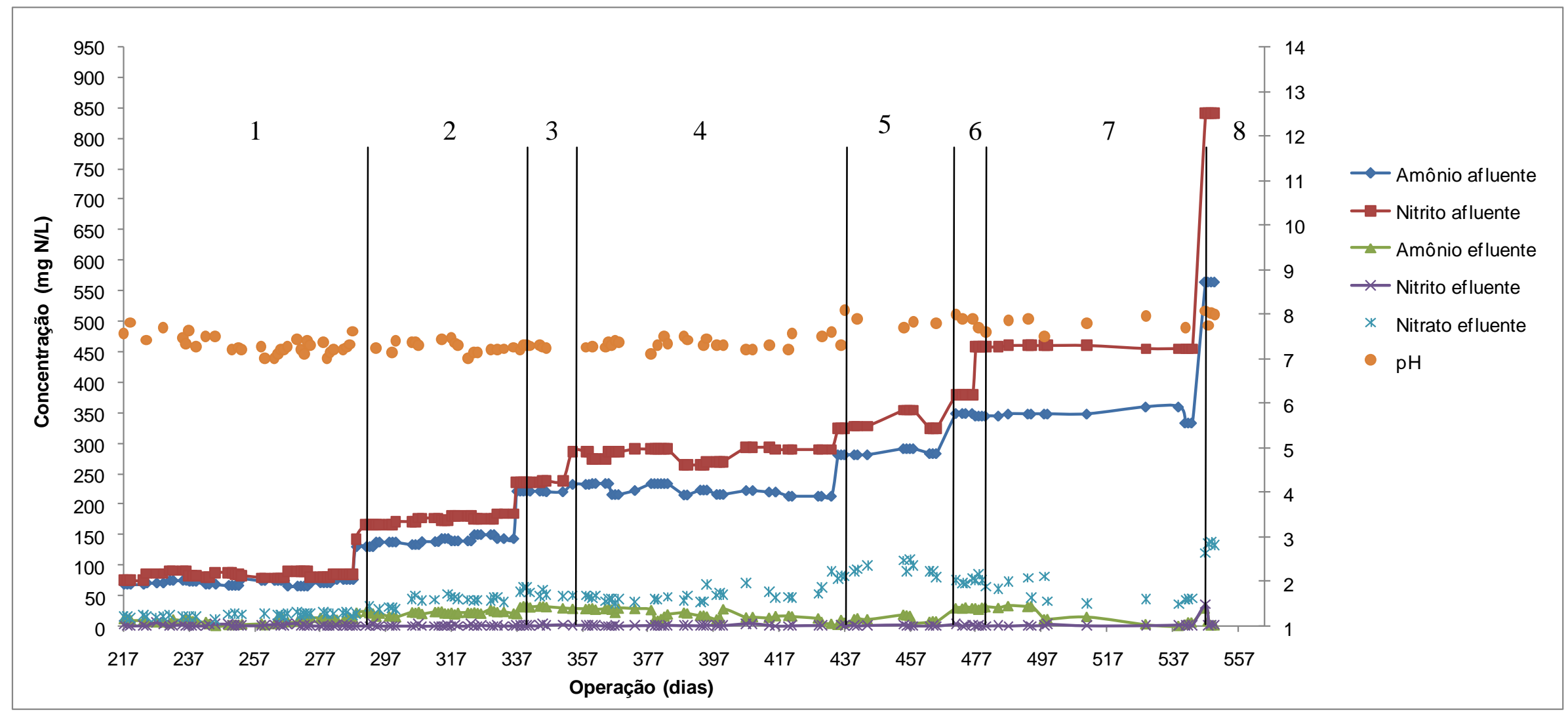

Figura 15. Variação dos compostos nitrogenados e pH durante a estratégia IV 
Com 294 dias a biomassa floculenta inoculada já se apresentava granulada, conforme apresentado na Figura 16. A biomassa anammox geralmente se apresenta na forma granulada (JETTEN et al., 2005; ARROJO et al., 2006).

O efluente do $344^{\circ}$ dia (início da etapa 3) apresentou aspecto turvo e avermelhado devido à presença de bactérias anammox em suspensão (Figura 17). Segundo JETTEN et al. (1998), as bactérias anammox apresentam coloração vermelha devido à elevada concentração de citocromo. As análises de microscopia desse efluente revelaram a presença abundante de cocos com tamanho aproximado de $1 \mu \mathrm{m}$ e aglomerados de cocos, semelhantes aos microrganismos anammox (Figura 18). Todas as espécies de bactérias anammox têm morfologia cocóide (STROUS et al., 1999a; SCHMID et al., 2003; JETTEN et al., 2005; STROUS et al., 2006).

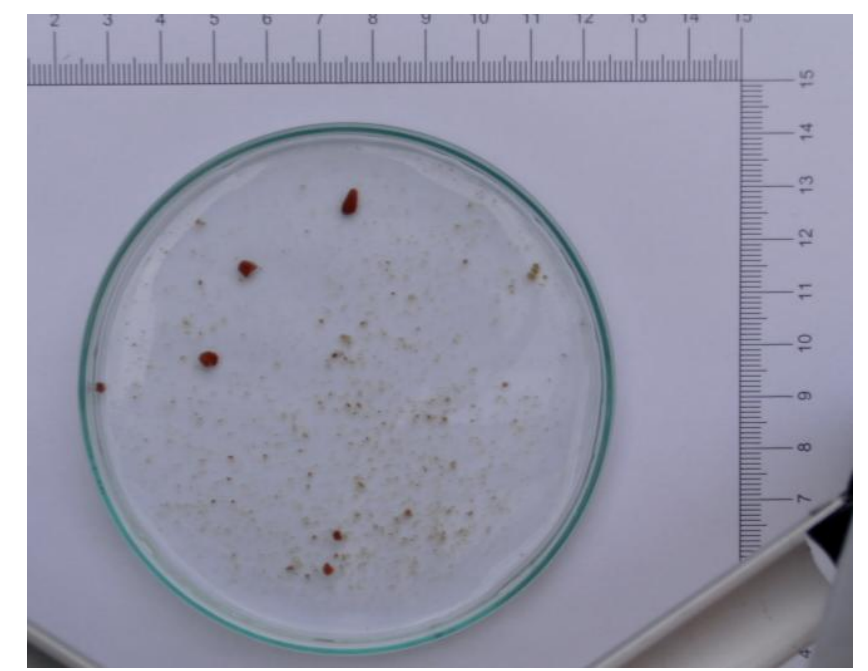

Figura 16. Biomassa granulada presente no RBS com 294 de operação

As bactérias anammox têm como característica o arranjo na forma de aglomerados (EGLI et al., 2001; EGLI et al., 2003). Todavia, VAN DER STAR et al. (2008a) obtiveram biomassa anammox em crescimento em suspensão em reator de membrana, com reduzidas concentrações de cálcio e magnésio e presença de $1 \mathrm{~g}$ de extrato de levedura/L. Sob tais condições, a cultura também apresentava aspecto avermelhado.

Esse crescimento em suspensão, ou desprendimento de microrganismos anammox dos grânulos durante o ciclo, ocorreu logo após o aumento da carga nitrogenada aplicada de 327,9 para $457,7 \mathrm{~g} \mathrm{~N} / \mathrm{m}^{3}$ dia e durou duas semanas. Isto pode ter acontecido devido ao choque de carga nitrogenada. No entanto, as causas deste acontecimento no RBS permanecem sem explicação plausível, uma vez que, em outros períodos quando a carga nitrogenada foi também aumentada, tal fato não ocorreu. 


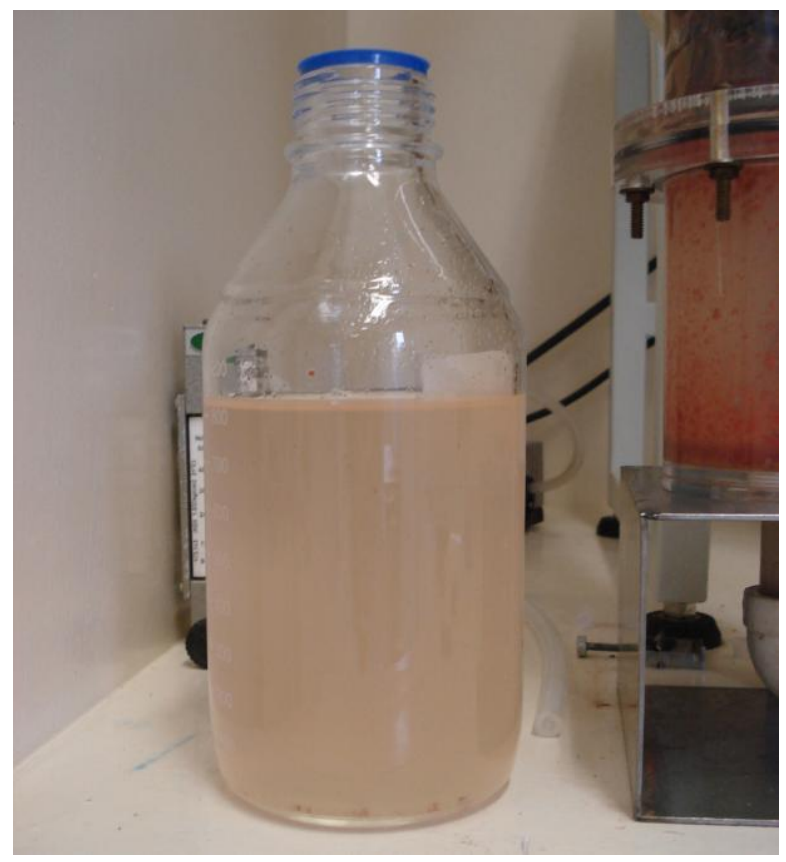

Figura 17. Efluente do RBS avermelhado do $344^{\circ}$ dia de operação

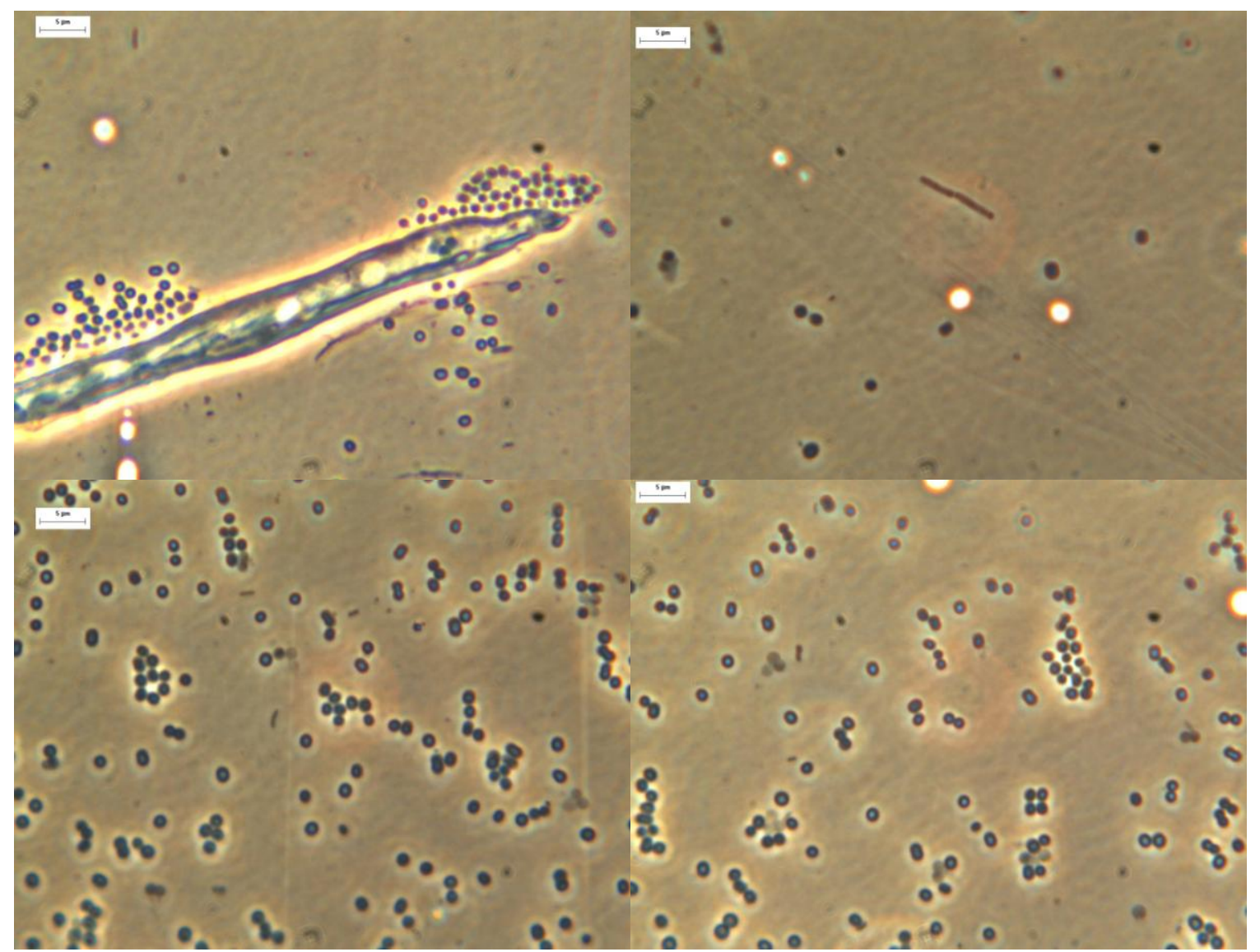

Figura 18. Microscopia ótica de contraste de fase do efluente do $344^{\circ}$ dia. Tamanho da barra: $5 \mu \mathrm{m}$

Pode-se observar pela Figura 15 que, à medida que se aumentava a carga aplicada, a concentração de nitrato efluente também aumentava, reforçando o metabolismo 
anammox, exceto na etapa 7. Nesse período, os valores efluentes de nitrato foram significativamente menores que o previsto pelo metabolismo anammox (relação de 0,26 mol de nitrato formado para cada mol de amônio consumido, Eq. 7).

A eficiência de remoção de nitrogênio $(90,2 \pm 3,4 \%)$ aumentou em relação à conversão nitrogênio $(97,5 \pm 1,5 \%)$ durante a etapa 7 da estratégia IV (Figura 19 e Tabela 9). O cálculo da carga nitrogenada removida (e eficiência de remoção) considera o nitrato formado, pois esta forma nitrogenada está no efluente e, portanto não foi removida.

Provavelmente, nesses períodos, houve atividade de microrganismos redutores de nitrato, pois as concentrações efluentes de amônio também foram reduzidas, ou seja, o nitrato gerado pela atividade anammox foi reduzido a nitrito e este, juntamente com o amônio remanescente, foi reduzido a nitrogênio molecular $\left(\mathrm{N}_{2}\right)$, novamente, pela atividade anammox. Este fato revelou desbalanceamento na produção de nitrato como pode ser observado na Figura 20.

A redução do nitrato pode ter sido realizada pelas próprias bactérias anammox. Segundo KARTAL et al. (2007a), microrganismos anammox tem via metabólica desnitrificante; ou seja, nitrato é reduzido a nitrito, e ou amônio e estes, por conseguinte, são transformados em $\mathrm{N}_{2}$. Ou, ainda, pode ter ocorrido a redução do nitrato por bactérias desnitrificantes, como por exemplo, Pseudomonas sp. Na estratégia IV, a remoção foi de $84,1 \pm 4,2 \%$ (média \pm desvio padrão, $n=155$ ) e eficiência de conversão de $95 \pm 2,5 \%$.

$$
\begin{aligned}
1 \mathrm{NH}_{4}{ }^{+}+1,32 \mathrm{NO}_{2}^{-}+0,066 \mathrm{HCO}_{3}{ }^{-}+0,13 \mathrm{H}^{+} & \longrightarrow \\
\longrightarrow & 1,02 \mathrm{~N}_{2}+0,26 \mathrm{NO}_{3}^{-}+0,066 \mathrm{CH}_{2} \mathrm{O}_{0,}{ }_{5} \mathrm{~N}_{0,15}+2,03 \mathrm{H}_{2} \mathrm{O}
\end{aligned}
$$




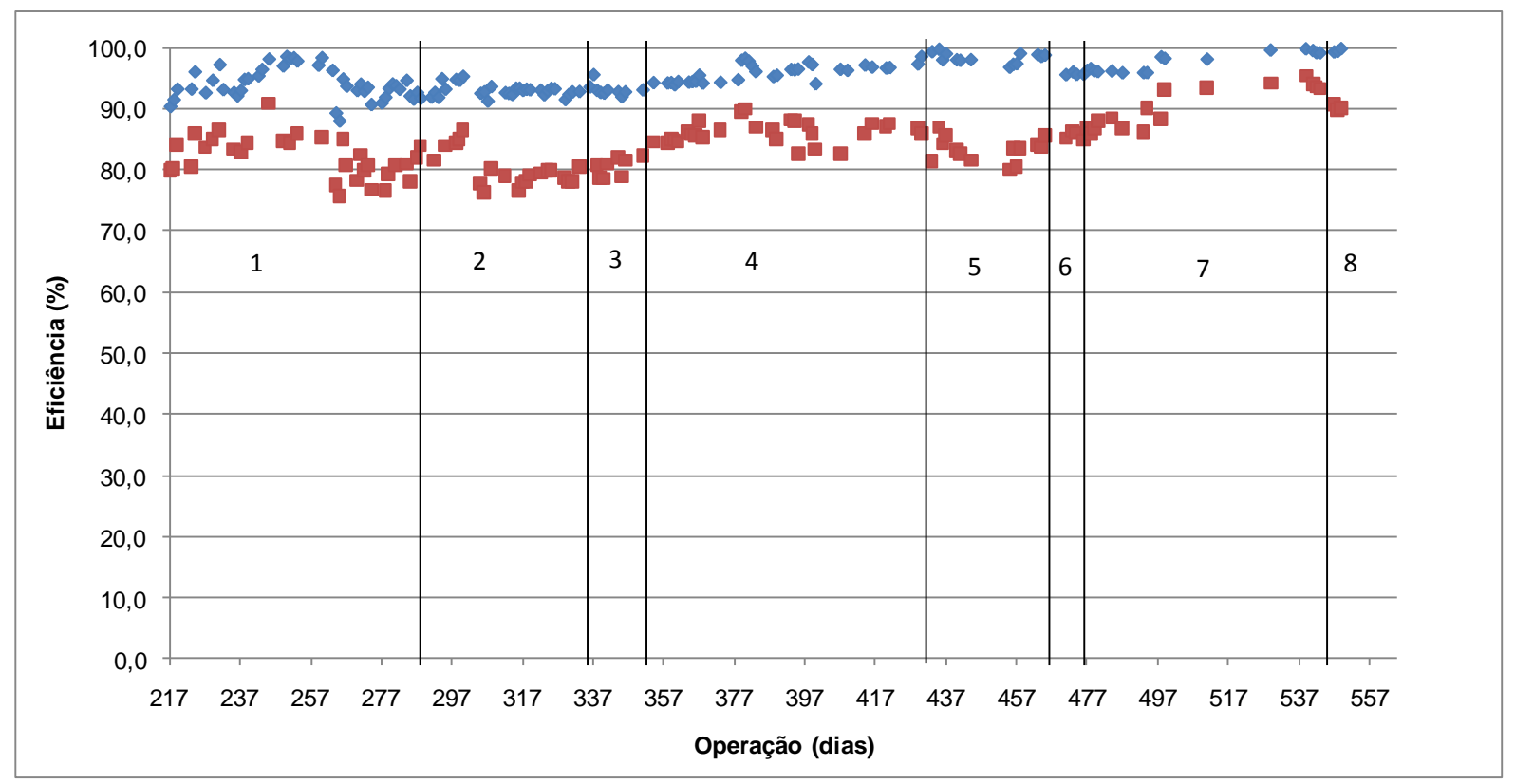

Figura 19. Eficiência de remoção de nitrogênio (vermelho) e eficiência de conversão de nitrogênio (azul) durante a estratégia IV

As relações estequiométricas entre amônio removido, nitrito removido e nitrato produzido, durante a estratégia IV, em comparação com os valores teóricos (Eq.7) (STROUS et al., 1998) estão apresentadas na Figura 20. Estes resultados mostram que, a partir de 340 dias de operação os valores determinados se aproximam dos valores teóricos indicando que a população de bactérias anammox presentes no reator elevou sua proporção dentro do consórcio microbiano, apesar da concentração de biomassa (SSV) ter se mantido relativamente estável e em torno de 0,5-0,73g SSV/L.

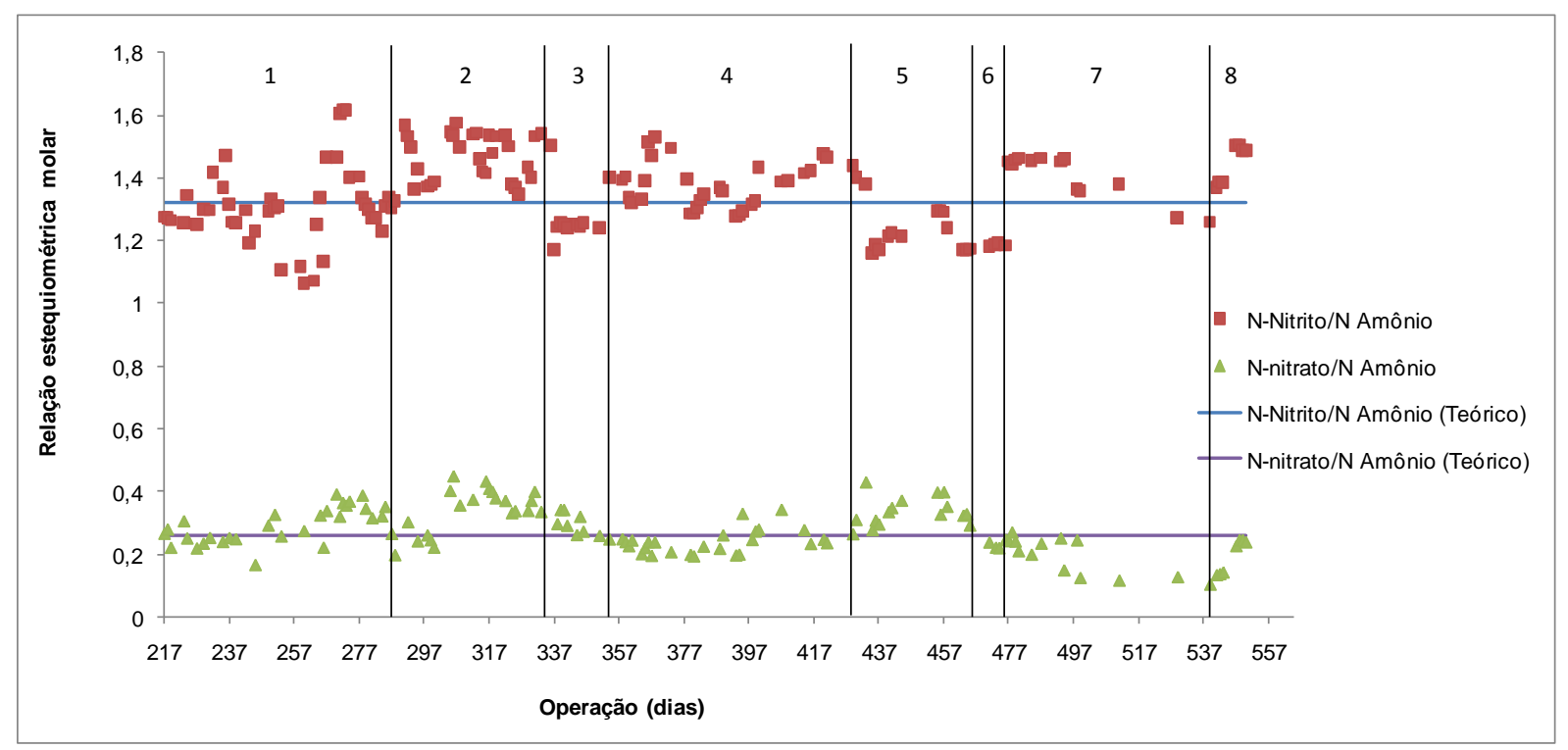

Figura 20. Relações estequiométricas de nitrito removido/amônio removido e nitrato produzido/amônio removido durante a estratégia IV 
Na Tabela 9 estão delineados os principais parâmetros de operação do RBS durante todas as etapas da estratégia IV. Pode-se observar que, tanto a eficiência de conversão, quanto a de remoção, aumentaram com tempo de operação do reator. A eficiência de conversão de nitrogênio na etapa 1 foi $94,0 \pm 2,5 \%$ e de remoção foi $82 \pm 3,4 \%$, já na etapa 8 esses valores foram $99,5 \pm 0,28$ e $90,2 \pm 0,4 \%$, respectivamente.

As relações estequiometrias entre os compostos nitrogenados estão bem próximas às previstas por STROUS et al. (1998), principalmente após a etapa 2 (340 dias), com

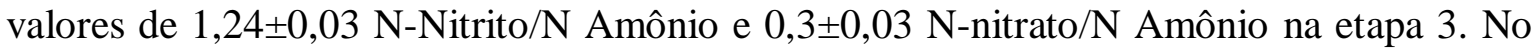
entanto, nas etapas 7 e 8 observa-se tendência em aumentar a proporção do nitrito

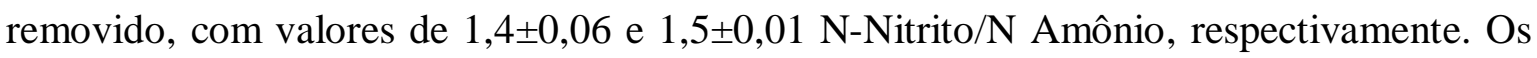

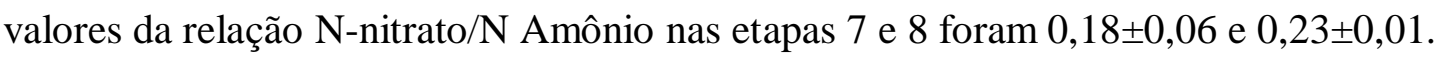

Tabela 9. Valor de carga nitrogenada, eficiência de remoção e conversão e relação estequiométrica na Estratégia IV

\begin{tabular}{ccccccc}
\hline Etapa & $\begin{array}{c}\text { Carga } \\
\text { nitrogenada } \\
\text { aplicada } \\
\left(\mathrm{g} \mathrm{N} / \mathrm{m}^{3} \mathrm{dia}\right)\end{array}$ & $\begin{array}{c}\text { Carga } \\
\text { nitrogenada } \\
\text { removida } \\
\left(\mathrm{g} \mathrm{N} / \mathrm{m}^{3} \text { dia }\right)\end{array}$ & $\begin{array}{c}\text { Eficiência de } \\
\text { conversão } \\
(\%)\end{array}$ & $\begin{array}{c}\text { Eficiência de } \\
\text { remoção } \\
(\%)\end{array}$ & $\begin{array}{c}\text { N-Nitrito/N } \\
\text { Amônio }\end{array}$ & $\begin{array}{c}\text { N-nitrato/N } \\
\text { Amônio }\end{array}$ \\
\hline 1 & $155,0 \pm 5,7$ & $132,9 \pm 11,8$ & $94,0 \pm 2,5$ & $82,0 \pm 3,4$ & $1,31 \pm 0,12$ & $0,29 \pm 0,06$ \\
2 & $313,6 \pm 12,3$ & $264,0 \pm 21,0$ & $92,9 \pm 0,9$ & $80,2 \pm 2,9$ & $1,47 \pm 0,08$ & $0,32 \pm 0,10$ \\
3 & $458,2 \pm 0,8$ & $376,3 \pm 23,8$ & $92,9 \pm 1,0$ & $80,4 \pm 1,5$ & $1,24 \pm 0,03$ & $0,30 \pm 0,03$ \\
4 & $505,9 \pm 14,0$ & $441,3 \pm 27,4$ & $95,9 \pm 1,5$ & $85,9 \pm 1,9$ & $1,38 \pm 0,07$ & $0,25 \pm 0,05$ \\
5 & $618,6 \pm 18,4$ & $516,0 \pm 12,5$ & $98,2 \pm 0,8$ & $83,4 \pm 2,0$ & $1,22 \pm 0,05$ & $0,33 \pm 0,04$ \\
6 & $728,4 \pm 0,0$ & $623,7 \pm 5,1$ & $95,6 \pm 0,2$ & $85,6 \pm 0,7$ & $1,19 \pm 0,01$ & $0,23 \pm 0,01$ \\
7 & $803,56 \pm 8,9$ & $725,2 \pm 28,4$ & $97,5 \pm 1,5$ & $90,2 \pm 3,4$ & $1,40 \pm 0,06$ & $0,18 \pm 0,06$ \\
8 & 1405,70 & $1267,9 \pm 5,9$ & $99,5 \pm 0,28$ & $90,2 \pm 0,4$ & $1,50 \pm 0,01$ & $0,23 \pm 0,01$ \\
\hline Média da & & & $95,06 \pm 2,5$ & $84,1 \pm 4,2$ & $1,36 \pm 0,12$ & $0,27 \pm 0,08$ \\
\hline Estratégia IV & & & & & &
\end{tabular}

\subsubsection{Perfis de Consumo de Nitrogênio no RBS}

Ao final das etapas 1, 2, 4, 6 e 7 de alimentação da estratégia IV, foram realizados perfis temporais no RBS. 
Na Etapa 1, os valores tiveram aumento até a segunda hora e após, houve consumo de praticamente todo nitrogênio. A concentração final de nitrato foi de $19 \mathrm{mg} \mathrm{N}-\mathrm{NO}_{3}{ }^{-} / \mathrm{L}$ (Figura 21), e relação molar de remoção de 1:1,09:0,25 $\left(\mathrm{N}-\mathrm{NH}_{4}{ }^{+}: \mathrm{N}-\mathrm{NO}_{2}{ }^{-}: \mathrm{N}-\mathrm{NO}_{3}{ }^{-}\right)$. Nessa etapa, a concentração afluente foi de 77,4 $\mathrm{mg} \mathrm{N}-\mathrm{NH}_{4}{ }^{+} / \mathrm{L}$ e $82,9 \mathrm{mg} \mathrm{N}-\mathrm{NO}_{2}{ }^{-} / \mathrm{L}$.

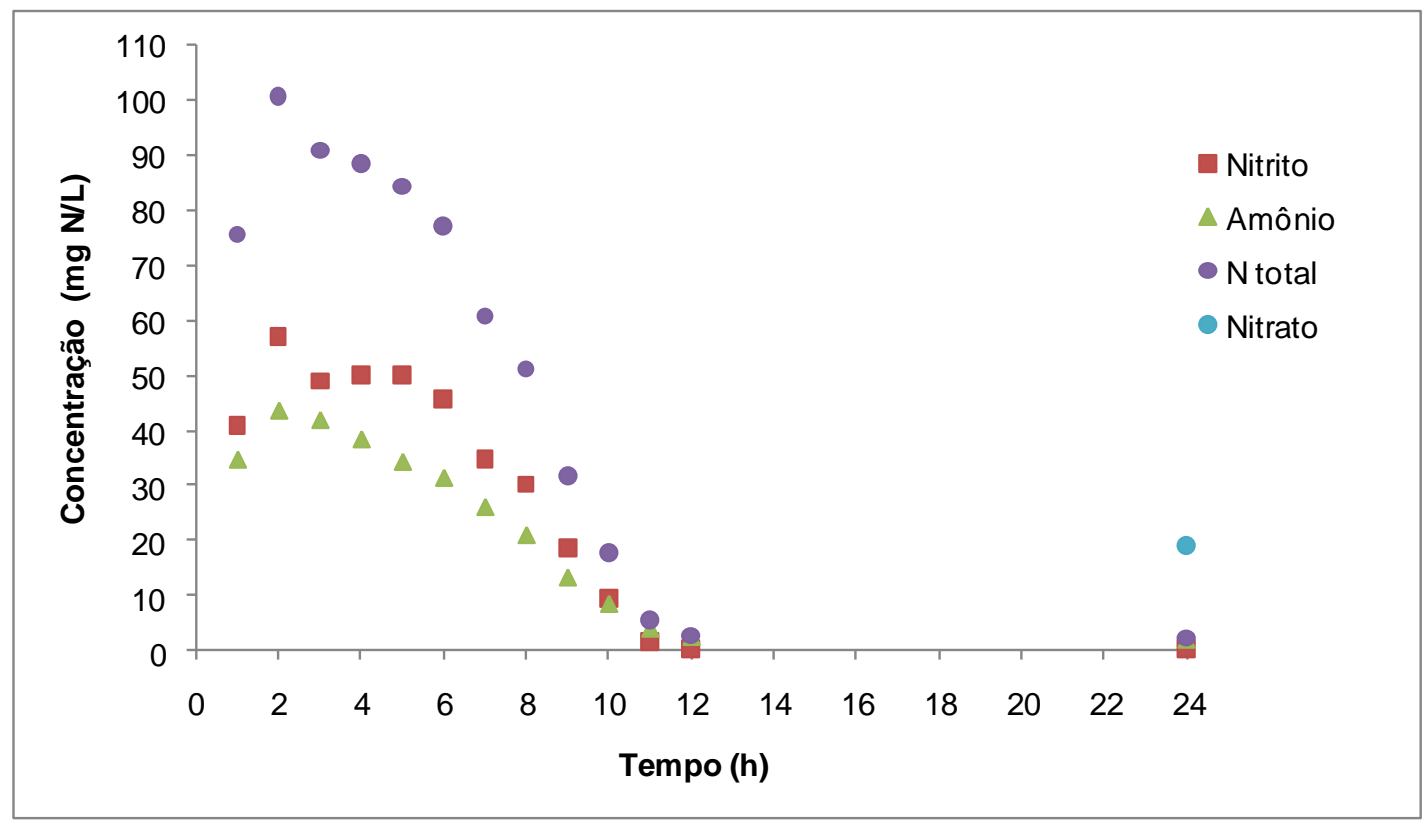

Figura 21. Perfil temporal dos compostos nitrogenados no RBS (Etapa 1), concentração: 77,4 mg $\mathrm{N}-\mathrm{NH}_{4}{ }^{+} / \mathrm{L}$ e $82,9 \mathrm{mg} \mathrm{N}-\mathrm{NO}_{2}{ }^{-} / \mathrm{L}$

Nas Etapas 2 e 4, os valores tiveram aumento até a segunda hora (Etapa 2) e terceira hora (Etapa 4) e após, houve conversão de praticamente todo nitrogênio, com

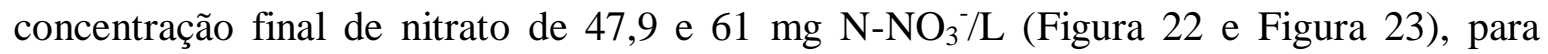
relação molar de remoção de 1:1,53:0,39 e 1:1,32:0,27, para etapa 2 e 4, respectivamente. $\mathrm{Na}$ etapa 2, a concentração afluente foi de $143,4 \mathrm{mg} \mathrm{N}-\mathrm{NH}_{4}{ }^{+} / \mathrm{L}$ e $184,5 \mathrm{mg} \mathrm{N}-\mathrm{NO}_{2}{ }^{-} / \mathrm{L}$. Na etapa 4, a concentração afluente foi de $233,7 \mathrm{mg} \mathrm{N}-\mathrm{NH}_{4}{ }^{+} / \mathrm{L}$ e $290 \mathrm{mg} \mathrm{N}-\mathrm{NO}_{2}{ }^{-} / \mathrm{L}$. 


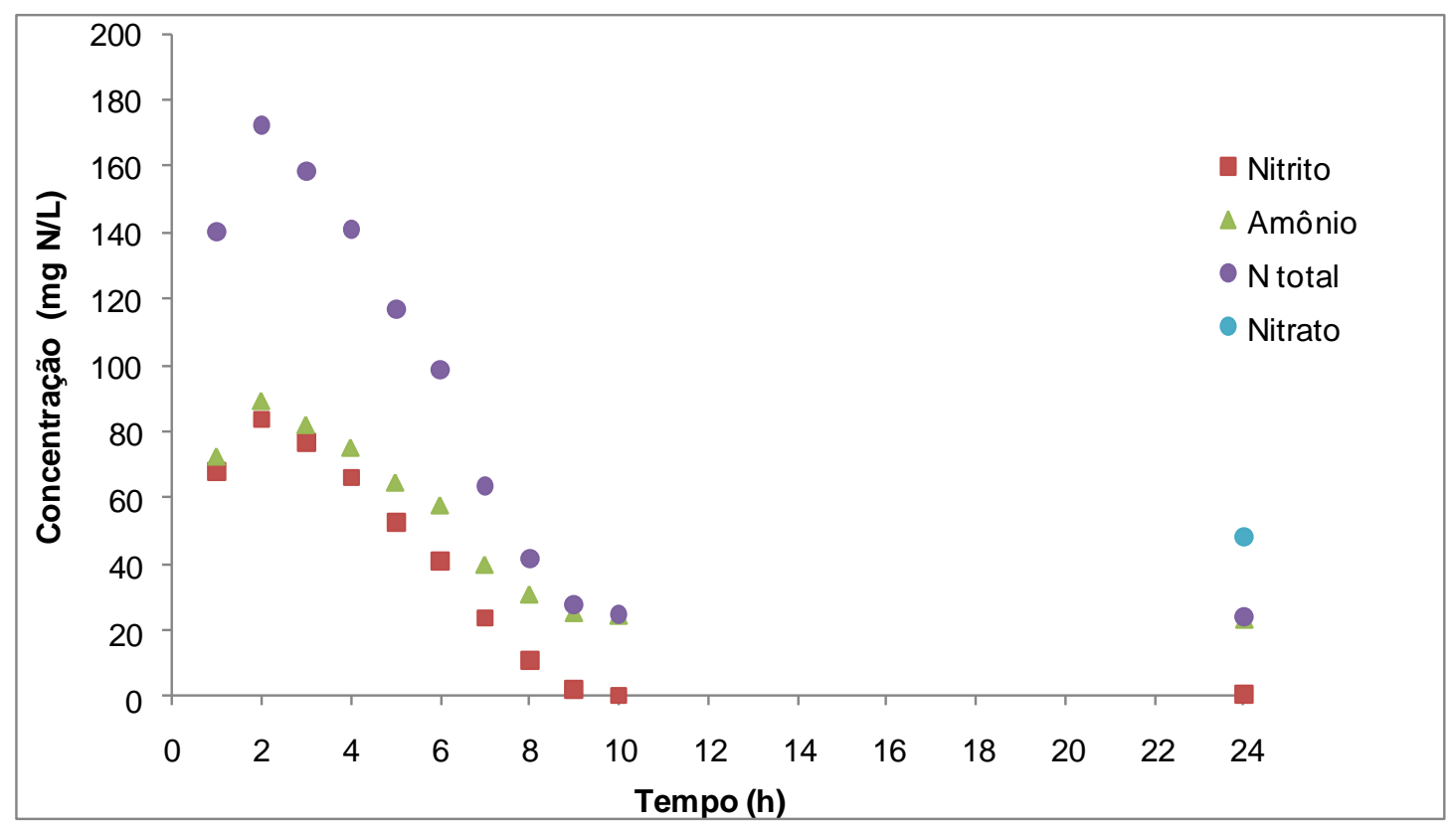

Figura 22. Perfil temporal dos compostos nitrogenados no RBS (Etapa 2), concentração afluente: $143,4 \mathrm{mg} \mathrm{N}-\mathrm{NH}_{4}{ }^{+} / \mathrm{L}$ e $184,5 \mathrm{mg} \mathrm{N}-\mathrm{NO}_{2}{ }^{-} / \mathrm{L}$

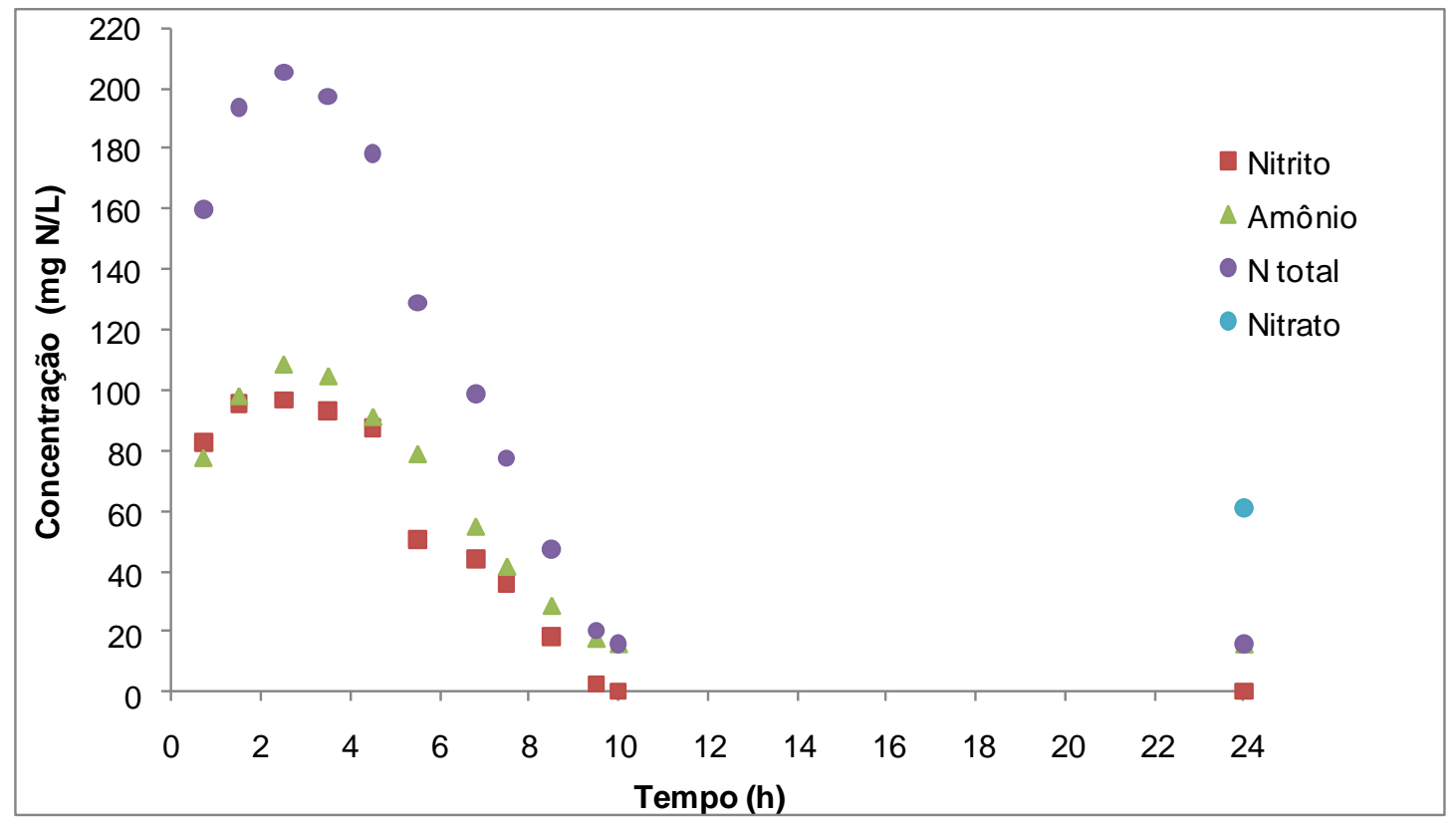

Figura 23. Perfil temporal dos compostos nitrogenados no RBS (Etapa 4), concentração afluente: $233,7 \mathrm{mg} \mathrm{N}-\mathrm{NH}_{4}{ }^{+} / \mathrm{L}$ e $290 \mathrm{mg} \mathrm{N}-\mathrm{NO}_{2}{ }^{-} / \mathrm{L}$

Nas Etapas 5 e 6, os valores tiveram aumento até a segunda hora (Etapa 5) e terceira hora (Etapa 6) e, após, houve o consumo de praticamente todo nitrogênio, e

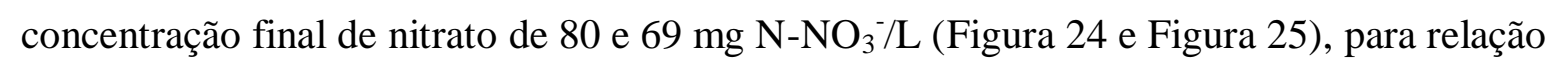
molar de remoção de 1:1,17:0,29 e 1:1,19:0,21, para Etapa 5 e 6, respectivamente. Na Etapa 5, a concentração afluente foi de $283 \mathrm{mg} \mathrm{N}-\mathrm{NH}_{4}{ }^{+} / \mathrm{L}$ e 323,5 mg N-NO${ }_{2}^{-} / \mathrm{L}$. Na Etapa 6, a concentração afluente foi de $348,8 \mathrm{mg} \mathrm{N}-\mathrm{NH}_{4}{ }^{+} / \mathrm{L}$ e $379,6 \mathrm{mg} \mathrm{N}-\mathrm{NO}_{2}{ }^{-} / \mathrm{L}$. 


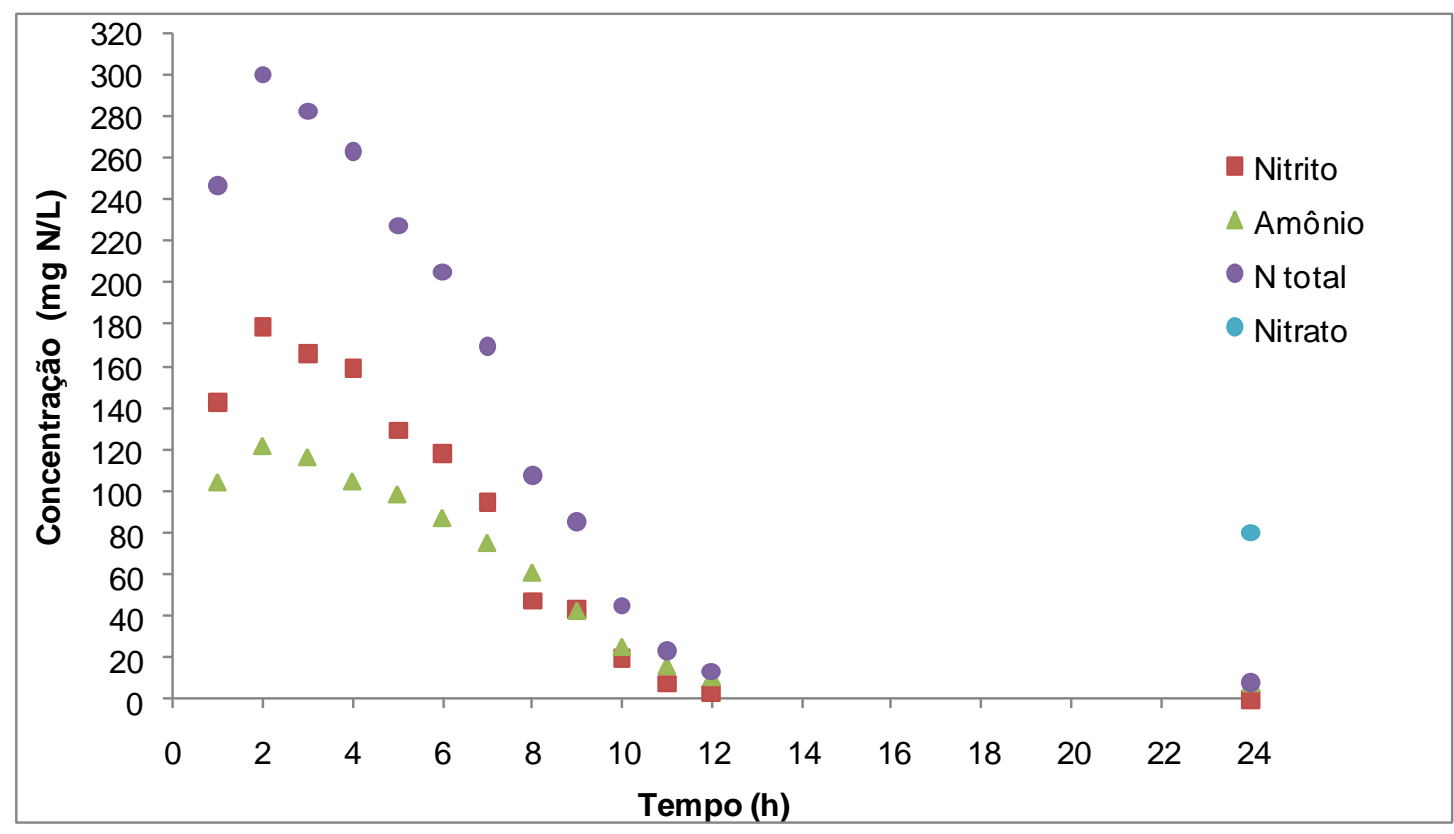

Figura 24. Perfil temporal dos compostos nitrogenados no RBS (Etapa 5), concentração afluente: $283 \mathrm{mg} \mathrm{N}-\mathrm{NH}_{4}{ }^{+} / \mathrm{L}$ e $323,5 \mathrm{mg} \mathrm{N}-\mathrm{NO}_{2}{ }^{-} / \mathrm{L}$

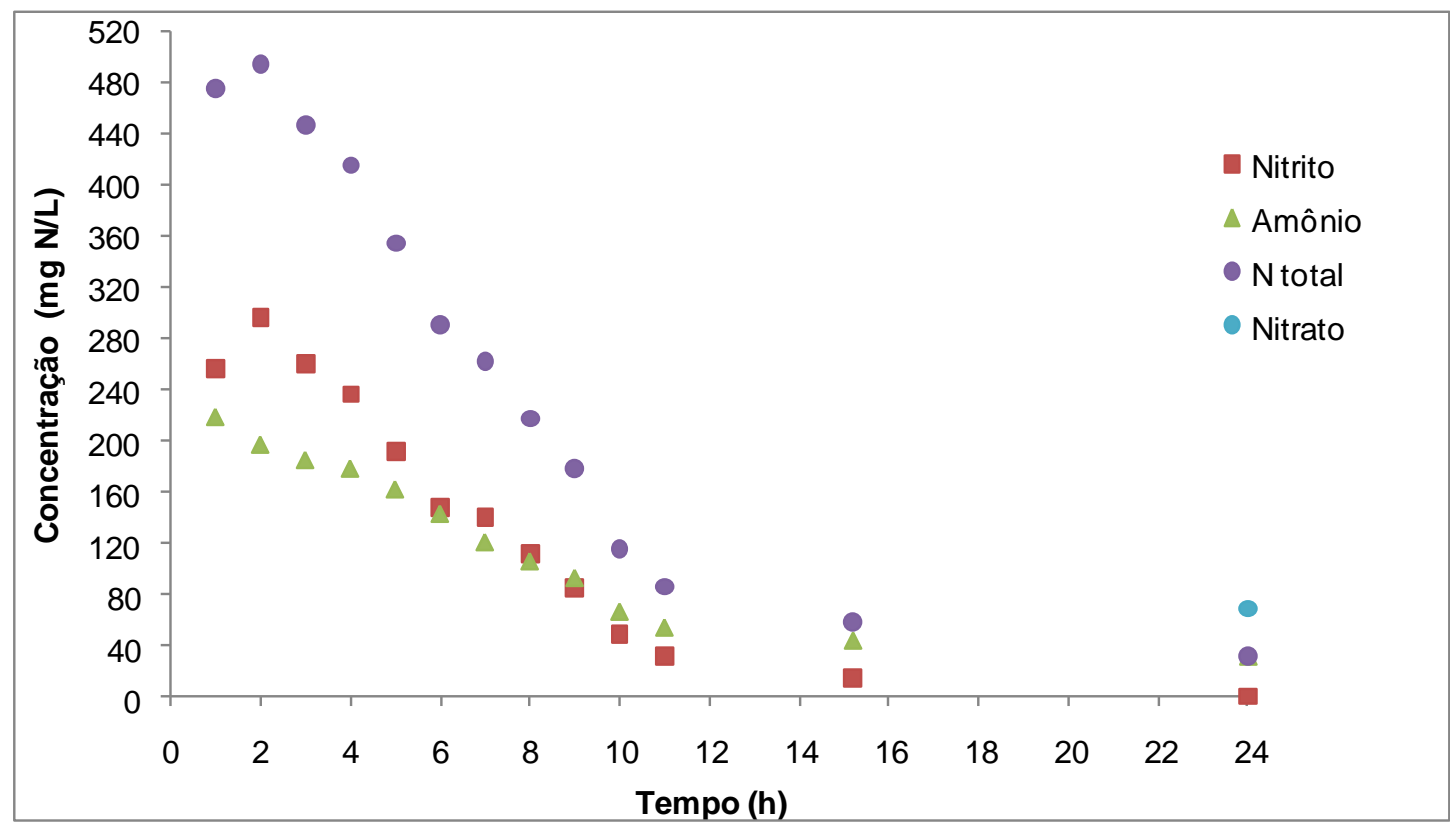

Figura 25. Perfil temporal dos compostos nitrogenados no RBS (Etapa 6), concentração afluente: $348,8 \mathrm{mg} \mathrm{N}^{-\mathrm{NH}_{4}}{ }^{+} / \mathrm{L}$ e $379,6 \mathrm{mg} \mathrm{N}-\mathrm{NO}_{2}{ }^{-} / \mathrm{L}$

De modo geral, o RBS foi operado sob condições bem abaixo da capacidade total de remoção. A duração do ciclo de operação poderia ter sido reduzida pela metade, ou poderia ter sido elevado o tempo de alimentação com concentrações mais elevadas de nitrogênio, proporcionando maior Carga Nitrogenada Aplicada (CNA). 


\subsection{ENSAIOS FISIOLÓGICOS DE ATIVIDADE ANAMMOX ESPECÍFICA}

\subsubsection{Influência da Frequência de Agitação}

Entre os dias 383 e 433 o RBS foi submetido a diferentes frequiências de agitação. O reator sempre foi operado em $50 \mathrm{rpm}\left(0,008018 \mathrm{~kW} / \mathrm{m}^{3}\right)$. Durante os ensaios para verificar a influência da agitação, o reator foi submetido à agitação testada somente durante a batelada do ensaio, após o ensaio. A agitação retornava a $50 \mathrm{rpm}$. Após uma semana, o reator era submetido a novo ensaio. Na Tabela 10, estão listadas todas frequências de agitação testadas no RBS.

Tabela 10. Frequências de agitação testadas $(\mathrm{N})$ e respectivas potências específicas aplicadas (P/V)

\begin{tabular}{cc}
\hline $\mathrm{N}(\mathrm{rpm})$ & $\mathrm{P} / \mathrm{V}\left(\mathrm{kW} / \mathrm{m}^{3}\right)$ \\
\hline 50 & 0,008018 \\
80 & 0,03284 \\
100 & 0,06414 \\
150 & 0,216474 \\
\hline
\end{tabular}

Pode ser observado o mesmo padrão de comportamento dos compostos nitrogenados em todos os ensaios, com aumento de concentração até 2-2,5 horas, coincidindo com o período de enchimento do reator (Figura 26, Figura 27, Figura 28 e Figura 29). Em todos os ensaios, a concentração afluente foi em média de $219 \mathrm{mg} \mathrm{N}$ $\mathrm{NH}_{4}{ }^{+} / \mathrm{L}$ e $289 \mathrm{mg} \mathrm{N}-\mathrm{NO}_{2}{ }^{-} / \mathrm{L}$.

Para a condição normal de operação (50rpm) (Figura 26), pode-se observar que o nitrito (substrato limitante) foi consumido até a $10^{\mathrm{a}}$ hora. Para essa condição, obteve-se valor de $\mathrm{k}_{\mathrm{NO} 2}$ - de $34,8 \mathrm{mg} \mathrm{N}-\mathrm{NO}_{2}{ }^{-} / \mathrm{g} \mathrm{SSV} \mathrm{h}$, e atividade anammox específica (AAE = $\mathrm{k}_{\mathrm{NH} 4+}$ ) de 33,5 mg N-NH${ }_{4}{ }^{+} / \mathrm{g} \mathrm{SSV}$ h [Figura 26 (b)]. A concentração final de nitrato foi de $42 \mathrm{mg} \mathrm{N}-\mathrm{NO}_{3}{ }^{-} / \mathrm{L}$, e a relação molar de remoção neste ensaio foi de 1:1,32:0,19 $\left(\mathrm{N}_{-} \mathrm{NH}_{4}{ }^{+}\right.$: $\mathrm{N}-\mathrm{NO}_{2}^{-}: \mathrm{N}-\mathrm{NO}_{3}^{-}{ }^{-}$. 

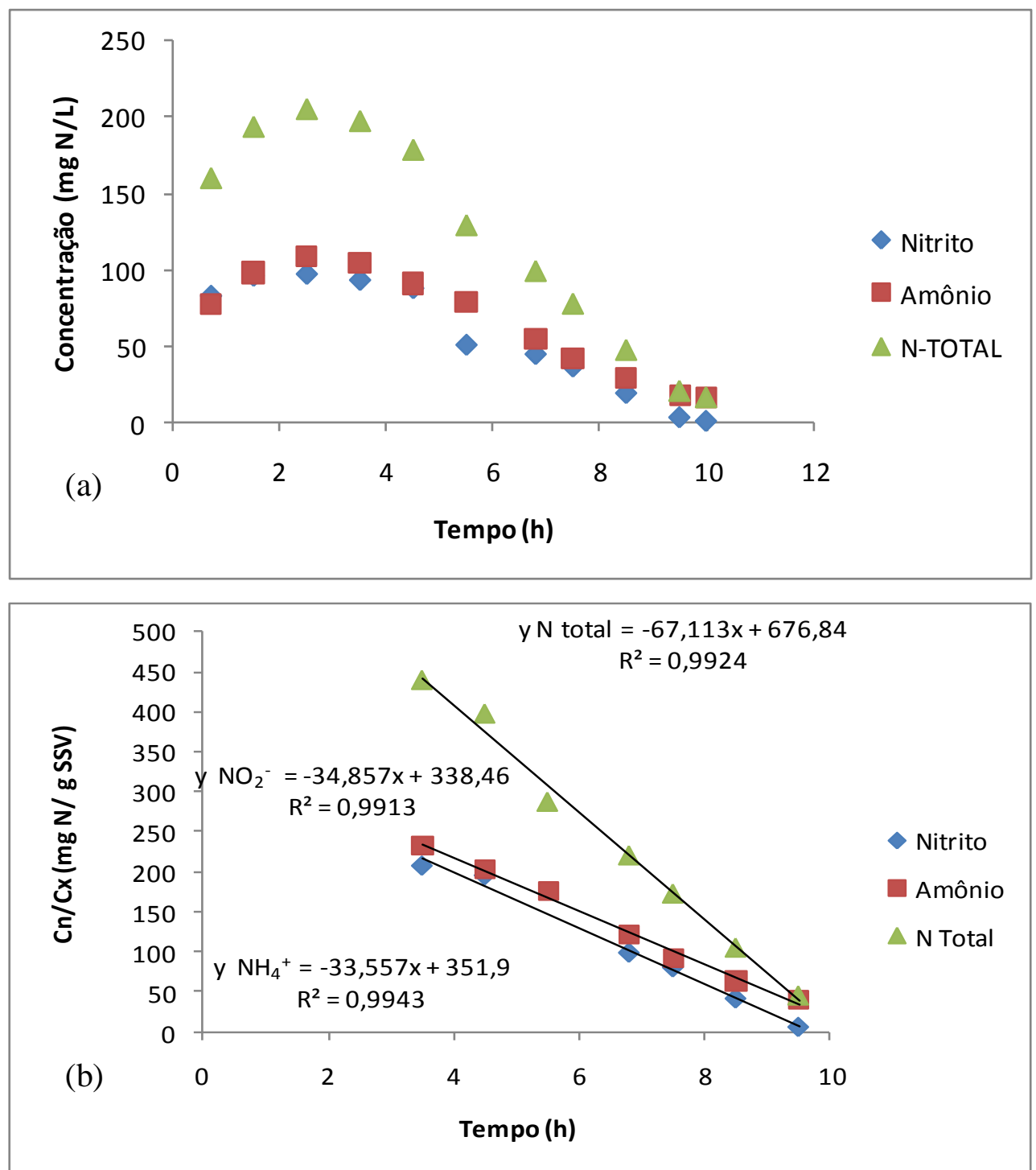

Figura 26. (a) Variação temporal de compostos nitrogenados no RBS submetido a 50 rpm; (b) Intervalo de ajuste dos parâmetros cinéticos, o eixo das ordenadas foi ajustado pela concentração de biomassa (SSV)

Quando o reator foi submetido a $80 \mathrm{rpm}\left(0,03284 \mathrm{~kW} / \mathrm{m}^{3}\right)$, as concentrações dos compostos nitrogenados alcançaram valor máximo e iguais a $120,1 \mathrm{mg} \mathrm{N}-\mathrm{NH}_{4}{ }^{+} / \mathrm{L}$ e 115,5 $\mathrm{mg} \mathrm{N}-\mathrm{NO}_{2}{ }^{-} / \mathrm{L}$ na segunda hora do ciclo (Figura 27), ligeiramente maior que em $50 \mathrm{rpm}$

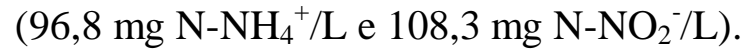

Quando a biomassa foi submetida a $80 \mathrm{rpm}$, a AAE foi de $28,8 \mathrm{mg} \mathrm{N}-\mathrm{NH}_{4}{ }^{+} / \mathrm{g} \mathrm{SSV}$ h [Figura 27 (b)]. Esse valor foi inferior ao obtido para $50 \mathrm{rpm}\left(33,5 \mathrm{mg} \mathrm{N}-\mathrm{NH}_{4}{ }^{+} / \mathrm{g} \mathrm{SSV} \mathrm{h}\right)$. O ensaio foi finalizado com 9,3 horas, e concentração final de nitrito e nitrato foram de 20 mg N-NO${ }_{2}{ }^{-} / \mathrm{L}$ e $51 \mathrm{mg} \mathrm{N}-\mathrm{NO}_{3}{ }^{-} / \mathrm{L}$, para relação molar de 1:1,33:0,27. O $\mathrm{K}_{\mathrm{N} \text { total }}$ desse ensaio foi $64,2 \mathrm{mg} \mathrm{N} / \mathrm{g} \mathrm{SSV} \mathrm{h,} \mathrm{menor} \mathrm{também} \mathrm{que} \mathrm{do} \mathrm{ensaio} \mathrm{à} 50 \mathrm{rpm} 67,1 \mathrm{mg} \mathrm{N} / \mathrm{g} \mathrm{SSV} \mathrm{h}$. 

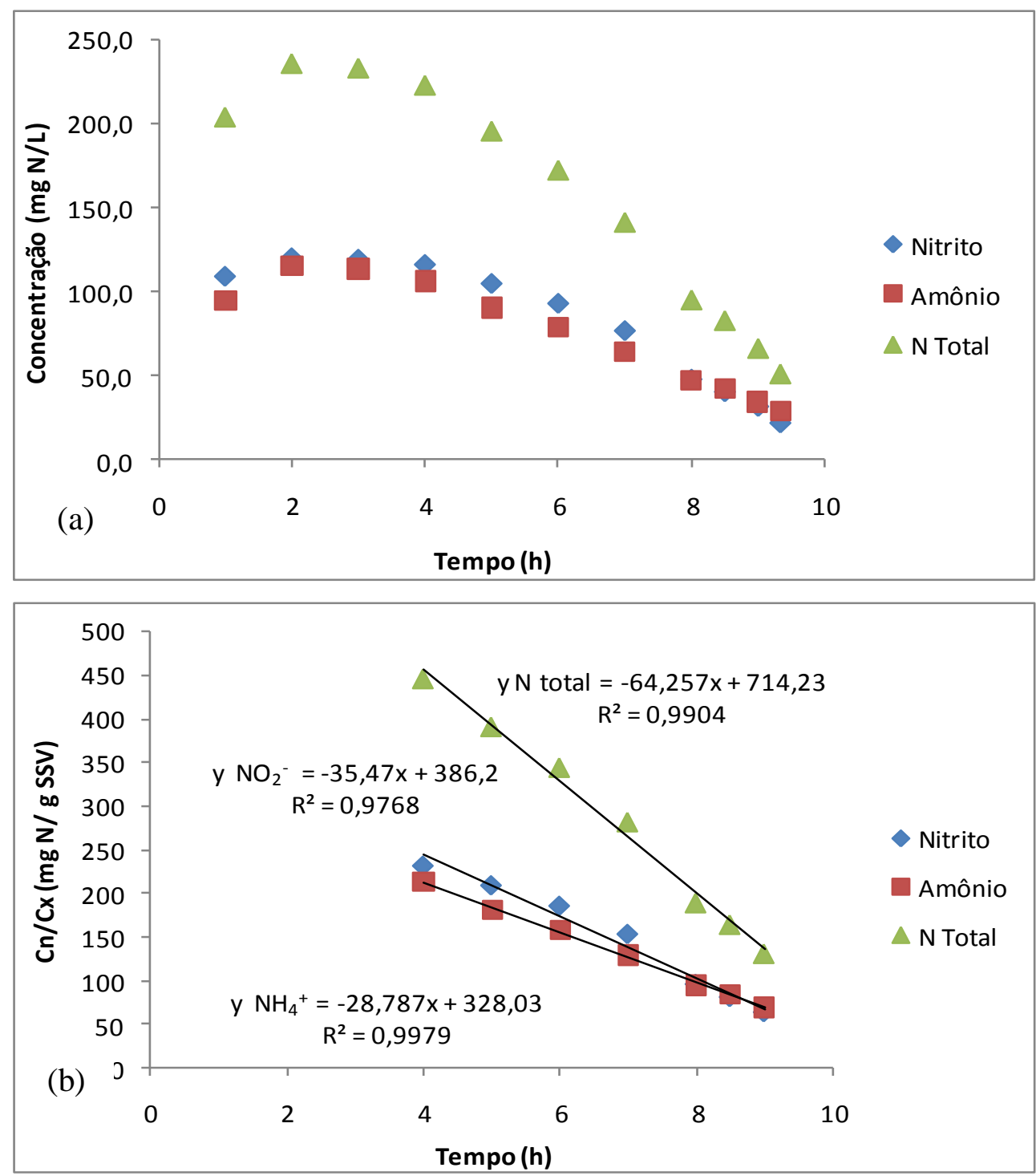

Figura 27. (a) Variação temporal de compostos nitrogenados no RBS submetido a 80 rpm; (b) Intervalo de ajuste dos parâmetros cinéticos, o eixo das ordenadas foi ajustado pela concentração de biomassa (SSV)

No perfil temporal do ensaio a $100 \mathrm{rpm}\left(0,06414 \mathrm{~kW} / \mathrm{m}^{3}\right)$ (Figura 28 a), pode-se observar valores máximos de amônio (104,5mg N-NH$\left.{ }_{4}{ }^{+} / \mathrm{L}\right)$ e nitrito $\left(144,1 \mathrm{mg} \mathrm{N}-\mathrm{NO}_{2}{ }^{-} / \mathrm{L}\right)$ em duas horas de ensaio. A concentração final de nitrato foi de $52 \mathrm{mg} \mathrm{N}-\mathrm{NO}_{3}{ }^{-} / \mathrm{L}$, com relação molar de remoção de 1:1,4:0,25. A AAE neste ensaio foi de 29,2 $\mathrm{mg} \mathrm{N}^{-\mathrm{NH}_{4}}{ }^{+} / \mathrm{g}$

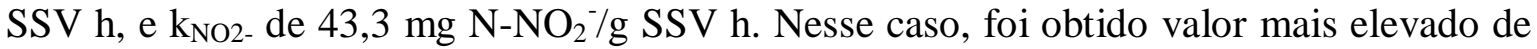
$\mathrm{k}_{\mathrm{N} \text {-total }}$ de todos os ensaios testados 72,5 mg N/g SSV h (Figura 28 b). 

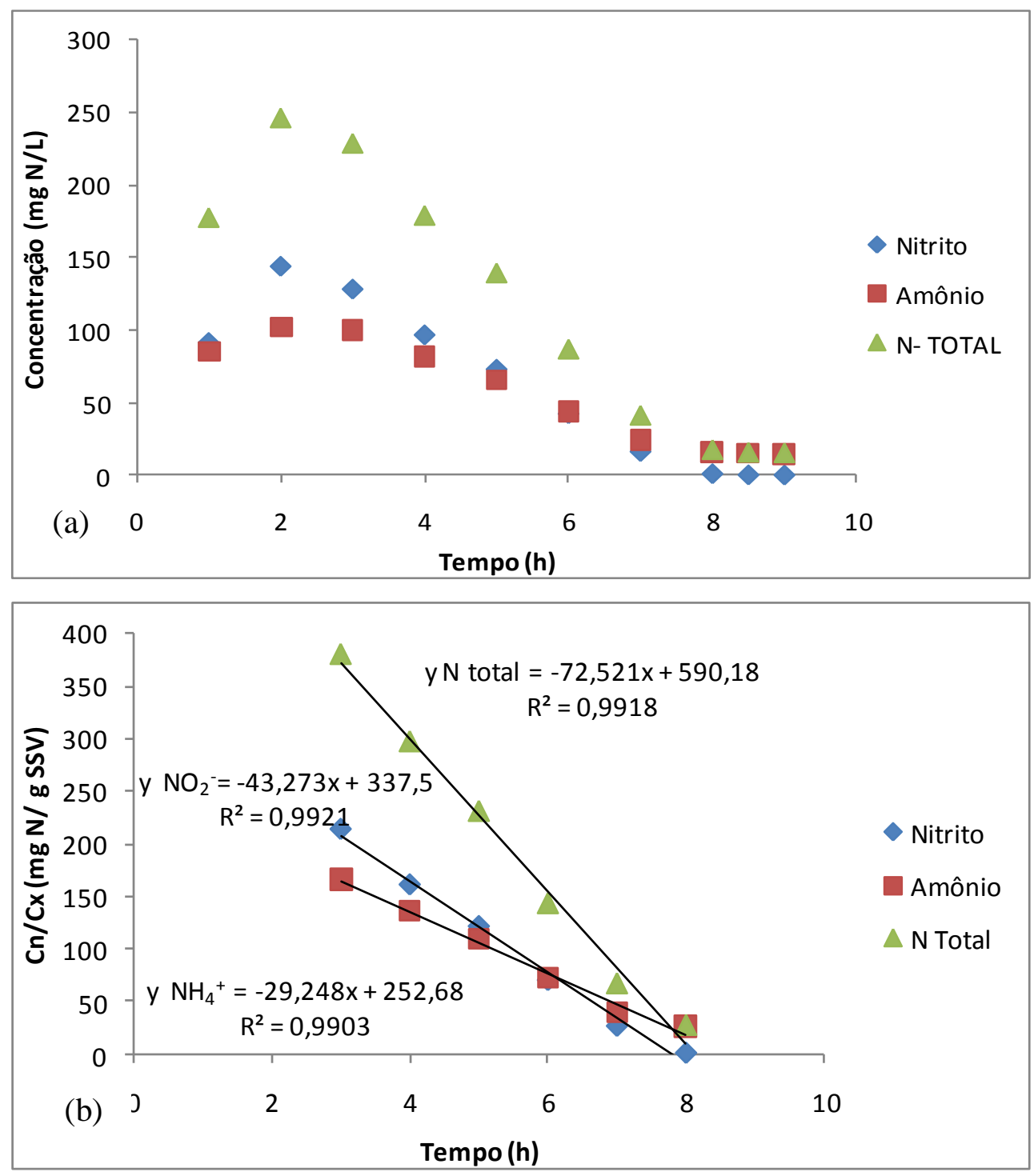

Figura 28. (a) Variação temporal de compostos nitrogenados no RBS submetido a $100 \mathrm{rpm}$; (b) Intervalo de ajuste dos parâmetros cinéticos, o eixo das ordenadas foi ajustado pela concentração de biomassa (SSV)

No perfil temporal do ensaio a $150 \mathrm{rpm}\left(0,216474 \mathrm{~kW} / \mathrm{m}^{3}\right)$ (Figura 29 a), pode-se observar valores máximos de amônio $\left(113,8{\mathrm{~N}-\mathrm{NH}_{4}}^{+} / \mathrm{L}\right)$ e nitrito $\left(154,6 \mathrm{mg} \mathrm{N}-\mathrm{NO}_{2}{ }^{-} / \mathrm{L}\right)$

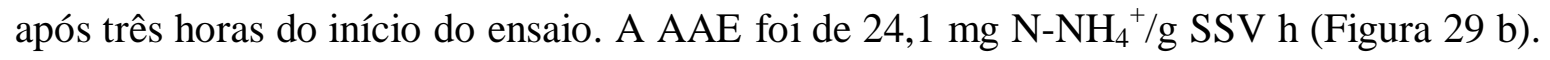
A concentração final de nitrato foi de $106 \mathrm{mg} \mathrm{N}-\mathrm{NO}_{3}{ }^{-} / \mathrm{L}$ e relação molar de 1:1,44:0,57. Este ensaio apresentou a maior produção de nitrato em relação ao consumo de amônio $\left(0,57 \mathrm{~mol}\right.$ de $\mathrm{N}-\mathrm{NO}_{3}{ }^{-} / \mathrm{mol}$ de $\left.\mathrm{N}-\mathrm{NH}_{4}{ }^{+}\right)$. 

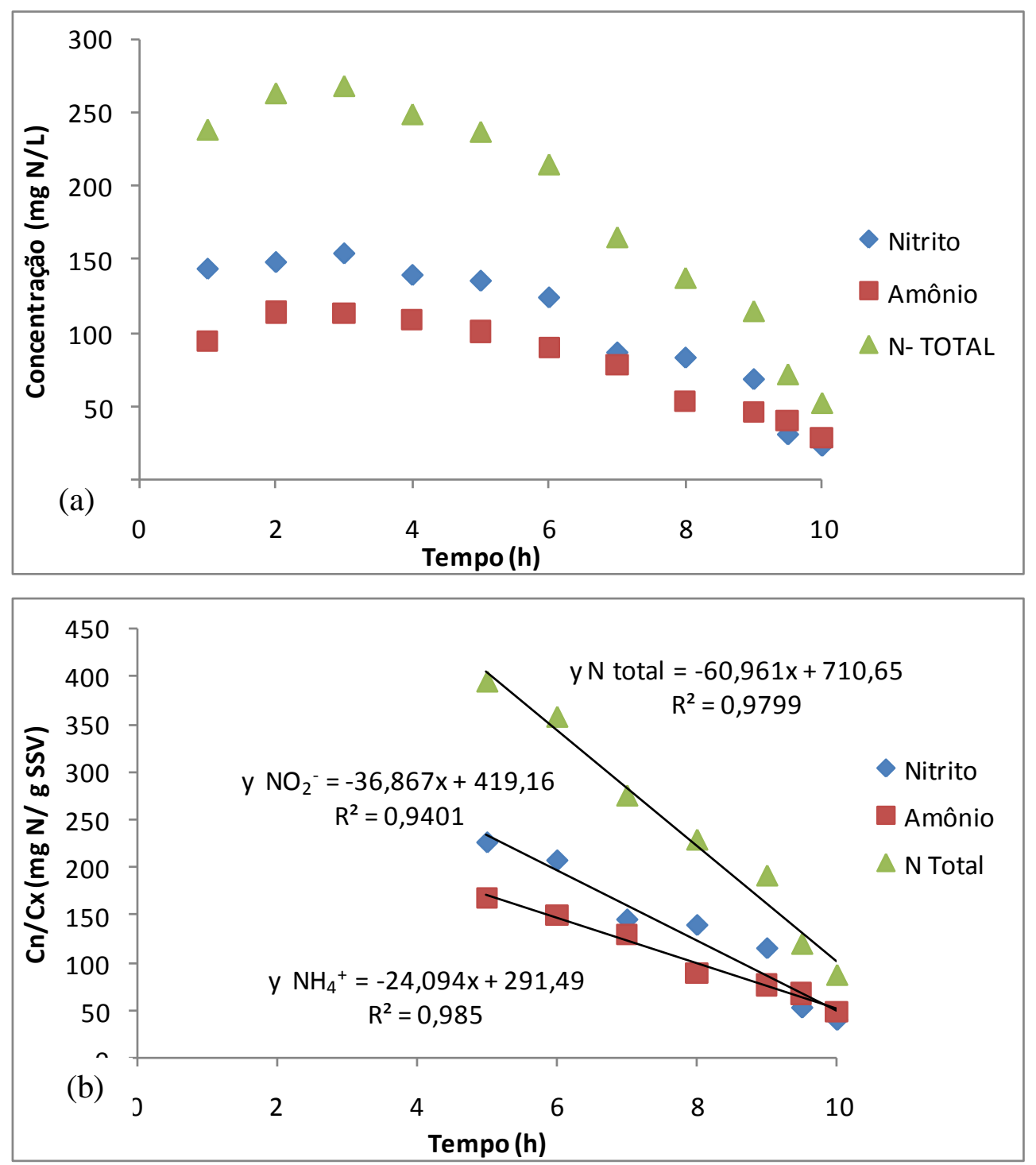

Figura 29. (a) Variação temporal de compostos nitrogenados no RBS submetido a $150 \mathrm{rpm}$; (b) Intervalo de ajuste dos parâmetros cinéticos, o eixo das ordenadas foi ajustado pela concentração de biomassa (SSV)

Em relação aos valores de AAE obtidos, constatou-se tendência à sua diminuição em função do aumento da agitação no RBS (Figura 30). Os valores obtidos foram de 33,6 e $24,1 \mathrm{mg} \mathrm{N}-\mathrm{NH}_{4}{ }^{+} / \mathrm{g} \mathrm{SSV} \mathrm{h}$ para 50 e $150 \mathrm{rpm}\left(0,008018 \mathrm{~kW} / \mathrm{m}^{3}\right.$ e $\left.0,216474 \mathrm{~kW} / \mathrm{m}^{3}\right)$, respectivamente.

No entanto, foi observado aumento no parâmetro cinético k NO2- no ensaio com frequiência da agitação de $100 \mathrm{rpm}\left(43,3 \mathrm{mg} \mathrm{N}-\mathrm{NO}_{2}{ }^{-} / \mathrm{g} \mathrm{SSV}\right.$ h). Nos outros ensaios, os valores mantiveram-se praticamente constantes, variando de 34,8 a $36,9 \mathrm{mg} \mathrm{N}-\mathrm{NO}_{2}{ }^{-} / \mathrm{g} \mathrm{SSV}$ h, para 50 e $150 \mathrm{rpm}$, respectivamente (Tabela 11).

Este aumento de k NO2- no ensaio a $100 \mathrm{rpm}$ ocorreu, provavelmente, devido as seguintes possibilidades: (i) ao favorecimento da desnitrificação endógena, causada pelo 
cisalhamento da biomassa, nessa frequiência de agitação; (ii) a atmosfera de $\mathrm{Ar} / \mathrm{CO}_{2}$ no headspace do reator pode não ter sido suficiente para manter a anaerobiose nessa frequiência de agitação, então ocorreu nitratação por BNO e, posterior redução do nitrato, pois neste ensaio não houve formação de nitrato além daquele produzido pela oxidação anaeróbia do amônio.

Já no ensaio com frequência de $150 \mathrm{rpm}$ o que ocorreu foi diferente. Provavelmente ocorreu a nitratação, mas não ocorreu redução do nitrato, uma vez que nessa condição ocorreu acúmulo de nitrato além daquele previsto pelo processo anammox. Pode-se observar que, apesar, dos valores de $\mathrm{k}$ NO2- serem praticamente iguais aos ensaios com 50 e $80 \mathrm{rpm}$, esses valores foram maiores proporcionalmente em relação ao $\mathrm{k}_{\mathrm{NH} 4+}$, indicando favorecimento da utilização do nitrito em detrimento do amônio à maiores freqüências de agitação.

A relação molar de formação de nitrato deveria ser em torno de 0,26 , todavia, obteve-se valor de 0,57 no ensaio de $150 \mathrm{rpm}$. Além disso, houve maior conversão de nitrito nos dois ensaios com maior freqüência de agitação, com relação molar de remoção de nitrito em relação ao amônio removido de 1,4 e 1,44 para 100 e 150 rpm, respectivamente.

ARROJO et. al. (2006) variaram a agitação entre $60 \mathrm{rpm}\left(0,003 \mathrm{~kW} / \mathrm{m}^{3}\right)$ e $180 \mathrm{rpm}$ $\left(0,09 \mathrm{~kW} / \mathrm{m}^{3}\right)$ em RBS e não observaram mudança significativa na AAE, mas houve diminuição significativa a $250 \mathrm{rpm}\left(0,023 \mathrm{~kW} / \mathrm{m}^{3}\right)$. No entanto, os autores calcularam a AAE em função do nitrogênio total, cujo valor médio foi de 16,67 mg N/g SSV h entre 60 e $180 \mathrm{rpm}$. Tal valor representou cerca de $25 \%$ dos valores encontrados nesse trabalho (Tabela 11).

Pode-se observar, ainda, que $154,6{\mathrm{mg} \mathrm{N}-\mathrm{NO}_{2}}^{-} / \mathrm{L}$ na terceira hora do ensaio a 150 rpm não causou inibição da biomassa.

A melhor condição de agitação (e potência específica aplicada) no RBS foi $50 \mathrm{rpm}$ $\left(0,008018 \mathrm{~kW} / \mathrm{m}^{3}\right)$, pois o aumento da potência aplicada não leva a aumento significativo da AAE da biomassa. 


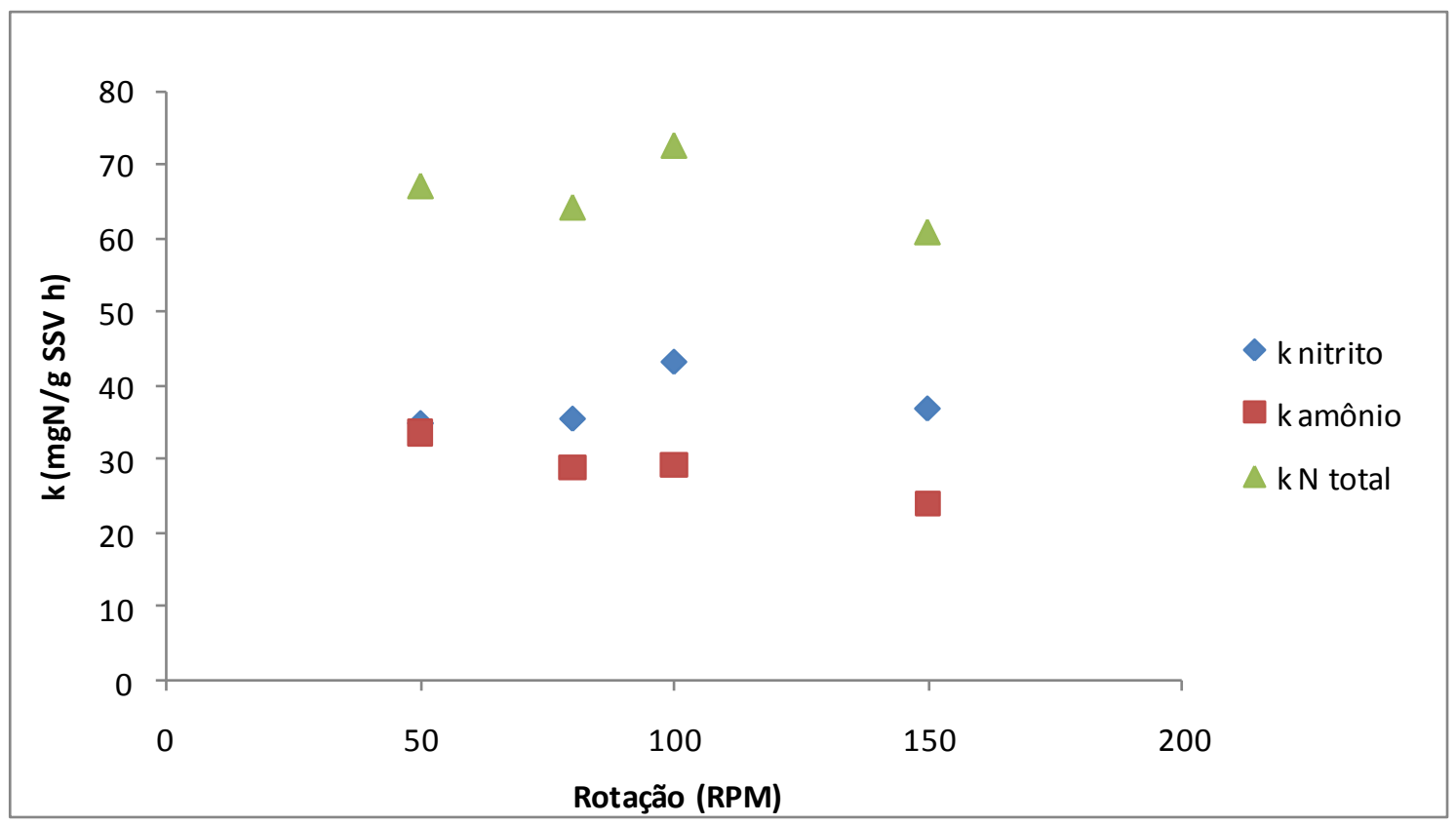

Figura 30. Variação dos parâmetros cinéticos $\mathrm{k}_{\mathrm{NH} 4+}(\mathrm{AAE}), \mathrm{k}_{\mathrm{NO2}-}$ e $\mathrm{k}_{\mathrm{N} \text { total }}$ em função da agitação no RBS

Tabela 11. Parâmetros cinéticos específicos da biomassa submetida a diferentes freqüências de agitação no RBS

\begin{tabular}{cccc}
\hline $\begin{array}{c}\text { Agitação } \\
(\mathrm{rpm})\end{array}$ & $\begin{array}{c}\mathrm{k}_{\text {nitrito }} \\
\left(\mathrm{mg} \mathrm{N}_{\mathrm{NO}}{ }_{2} / \mathrm{g} \mathrm{SSV} \mathrm{h}\right)\end{array}$ & $\begin{array}{c}\mathrm{k}_{\text {amônio }} \\
\left(\mathrm{mg} \mathrm{N}-\mathrm{NH}_{4}{ }^{+} / \mathrm{g} \mathrm{SSV} \mathrm{h}\right)\end{array}$ & $\begin{array}{c}\mathrm{k}_{\mathrm{N} \text { total }} \\
(\mathrm{mg} \mathrm{N} / \mathrm{g} \mathrm{SSV} \mathrm{h})\end{array}$ \\
\hline 50 & 34,8 & 33,5 & 67,1 \\
80 & 35,5 & 28,8 & 64,2 \\
100 & 43,3 & 29,2 & 72,5 \\
150 & 36,9 & 24,1 & 61,0 \\
\hline
\end{tabular}

\subsubsection{Ensaios Fisiológicos em Reator de Batelada Descontínuo sem Agitação}

Os ensaios de AAE em batelada descontínuo e sem agitação (Figura 31) foram realizados para verificar o comportamento da biomassa submetida a diferentes temperaturas e concentração de compostos nitrogenados. 


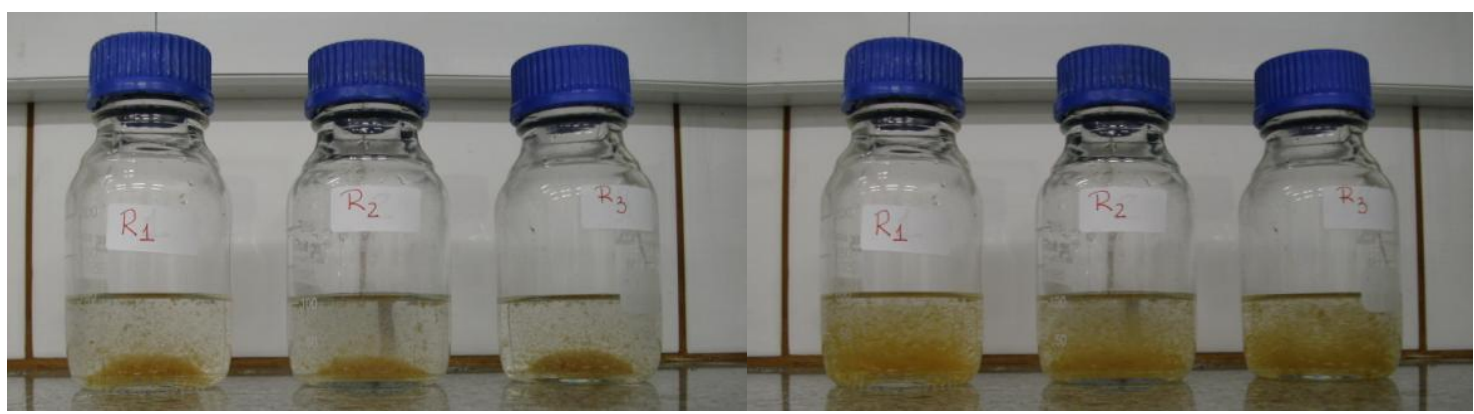

Figura 31. Reatores em batelada descontínuos do ensaio de atividade anammox específica

\subsubsection{Variação da Concentração dos Compostos Nitrogenados}

O perfil temporal de consumo dos compostos nitrogenados no ensaio com concentração inicial de 32,8 $\mathrm{mg} \mathrm{N}-\mathrm{NH}_{4}{ }^{+} / \mathrm{L}$ e $31,6 \mathrm{mg} \mathrm{N}^{-N^{2}}{ }_{2}^{-} / \mathrm{L}$ (Ensaio 1) foi finalizado com três horas (Figura 32 e Figura 33). Os valores finais de amônio, nitrito e nitrato foram, respectivamente, de $11 \mathrm{mg} \mathrm{N}-\mathrm{NH}_{4}{ }^{+} / \mathrm{L}$ e $4,7 \mathrm{mg} \mathrm{N}-\mathrm{NO}_{2}{ }^{-} / \mathrm{L}$ e $5,3 \mathrm{mg} \mathrm{N}-\mathrm{NO}_{3}{ }^{-} / \mathrm{L}$. A relação molar de remoção nesse ensaio foi 1:1,24:0,24.

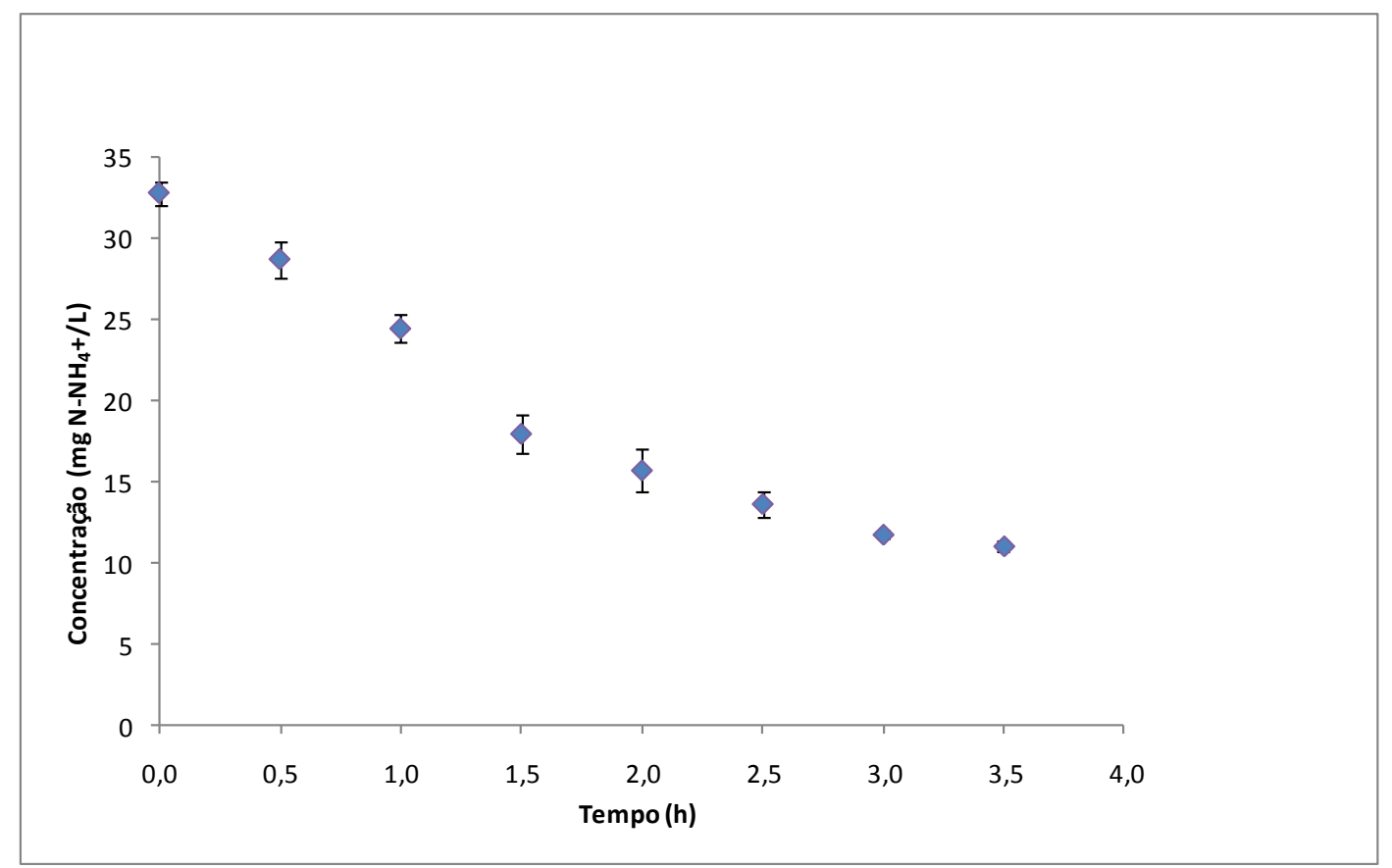

Figura 32. Variação temporal de consumo de amônio no reator em batelada, sem agitação, do

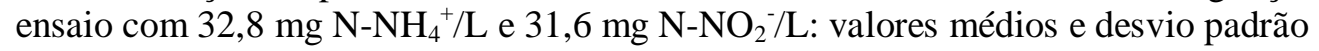




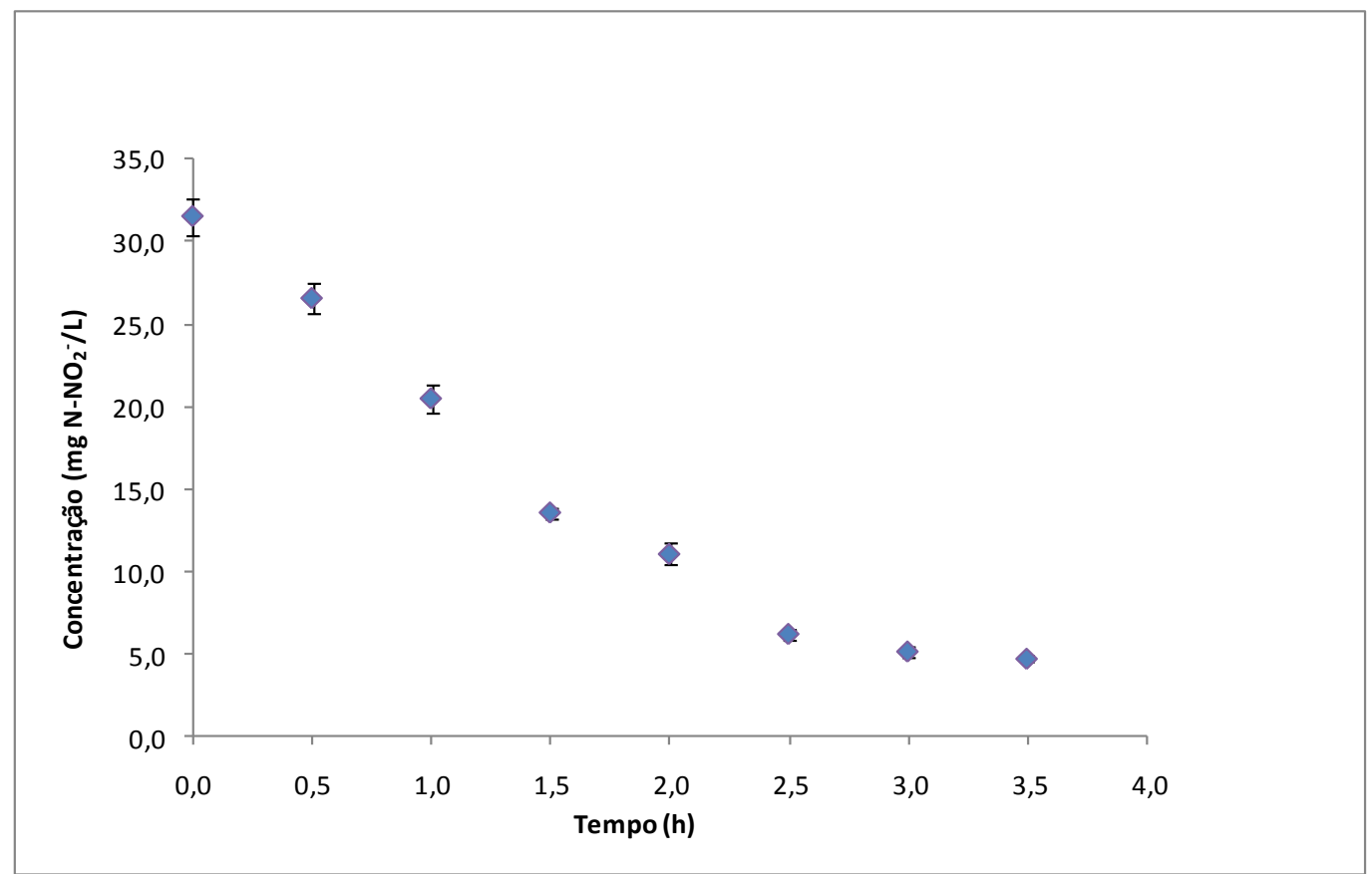

Figura 33. Variação temporal de consumo de nitrito nos reatores em batelada, sem agitação, do ensaio com 32,8 mg N-NH${ }_{4}^{+} / \mathrm{L}$ e 31,6 mg N-NO${ }_{2}{ }^{-} / \mathrm{L}$ : valores médios e desvio padrão

O intervalo de ajuste dos parâmetros cinéticos está apresentado na Figura 34. Podese observar que o consumo dos compostos nitrogenados foi constante e linear até 2,5 horas. $\mathrm{O}$ valor da AAE neste ensaio foi $20,1 \mathrm{mg} \mathrm{N}-\mathrm{NH}_{4}{ }^{+} / \mathrm{g} \mathrm{SSV} \mathrm{h}, \mathrm{k}_{\mathrm{NO} 2}$ - foi de $25,7 \mathrm{mg} \mathrm{N}-\mathrm{NO}_{2}{ }^{-} / \mathrm{g}$ SSV h.

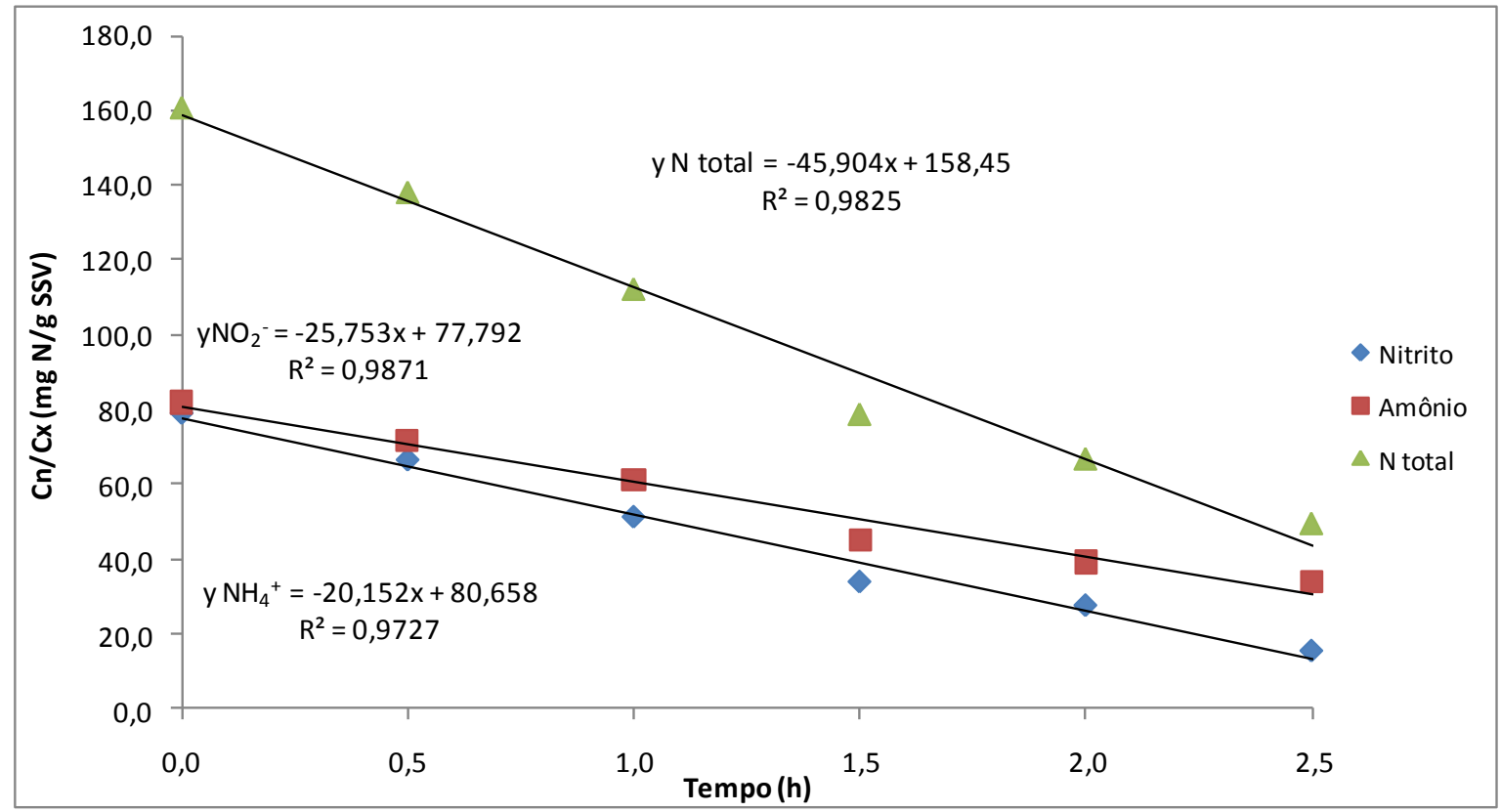

Figura 34. Intervalo de ajuste dos parâmetros cinéticos do ensaio com 33,8 mg N-NH${ }_{4}^{+} / \mathrm{L}$ e 31,6 $\mathrm{mg} \mathrm{N}-\mathrm{NO}_{2}{ }^{-} / \mathrm{L}$, o eixo das ordenadas foi ajustado pela concentração de biomassa (SSV) 
$\mathrm{O}$ ensaio com valores iniciais de $67{\mathrm{mg} \mathrm{N}-\mathrm{NH}_{4}}^{+} / \mathrm{L}$ e $73 \mathrm{mg} \mathrm{N}-\mathrm{NO}_{2}{ }^{-} / \mathrm{L}$ (Ensaio 2) teve duração de 8 horas (Figura 35 e Figura 36). O valor final de amônio, nitrito e nitrato foi de $19,2 \mathrm{mg} \mathrm{N}-\mathrm{NH}_{4}{ }^{+} / \mathrm{L}$ e $3 \mathrm{mg} \mathrm{N}-\mathrm{NO}_{2}{ }^{-} / \mathrm{L}$ e $16,6 \mathrm{mg} \mathrm{N}-\mathrm{NO}_{3}{ }^{-} / \mathrm{L}$, respectivamente, com relação molar nesse ensaio de 1:1,43:0,34.

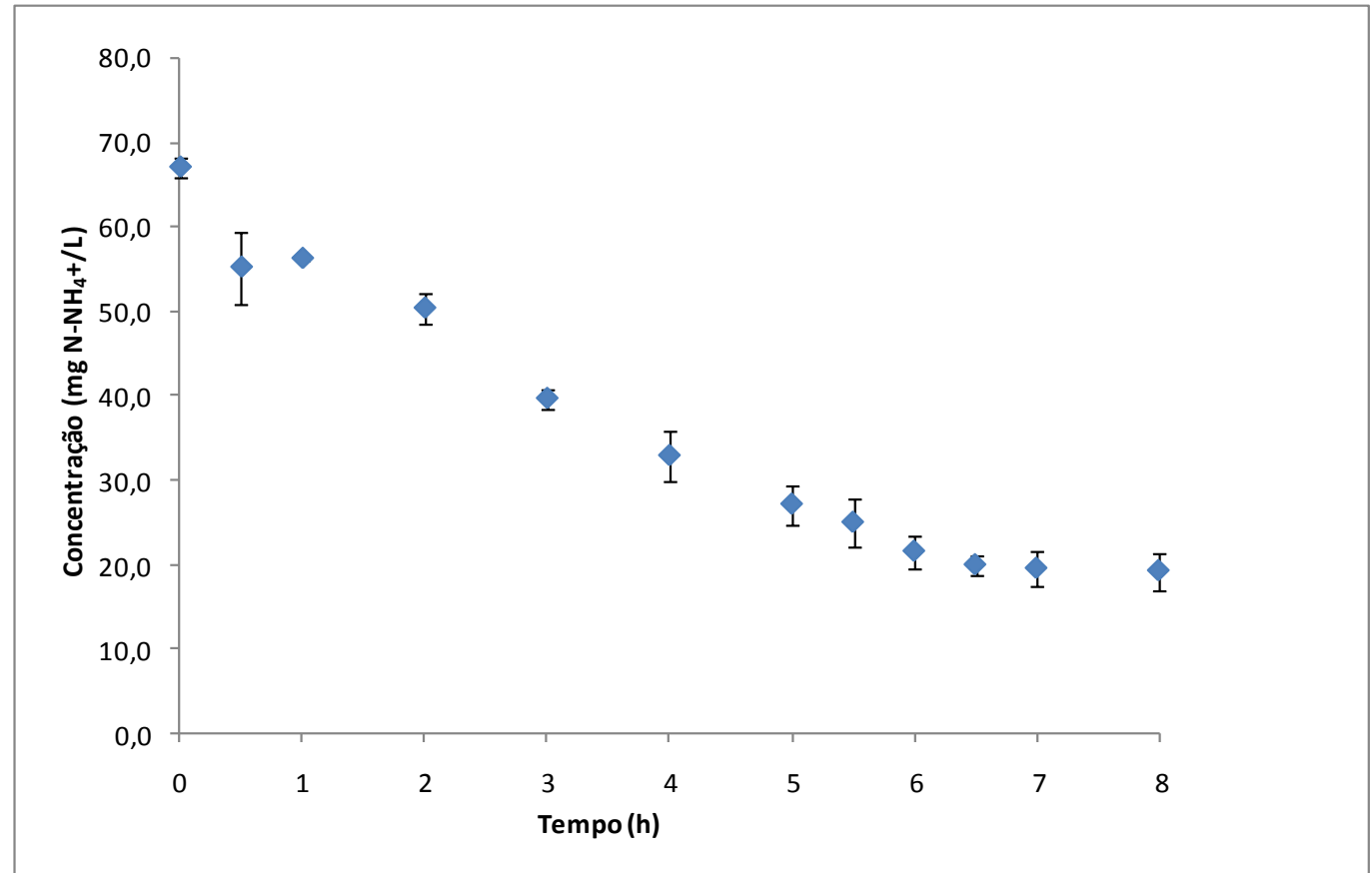

Figura 35. Variação temporal de consumo de amônio no reator em batelada, sem agitação, do ensaio com $67 \mathrm{mg} \mathrm{N}-\mathrm{NH}_{4}{ }^{+} / \mathrm{L}$ e $73 \mathrm{mg} \mathrm{N}-\mathrm{NO}_{2}{ }^{-} / \mathrm{L}$ : valores médios e desvio padrão

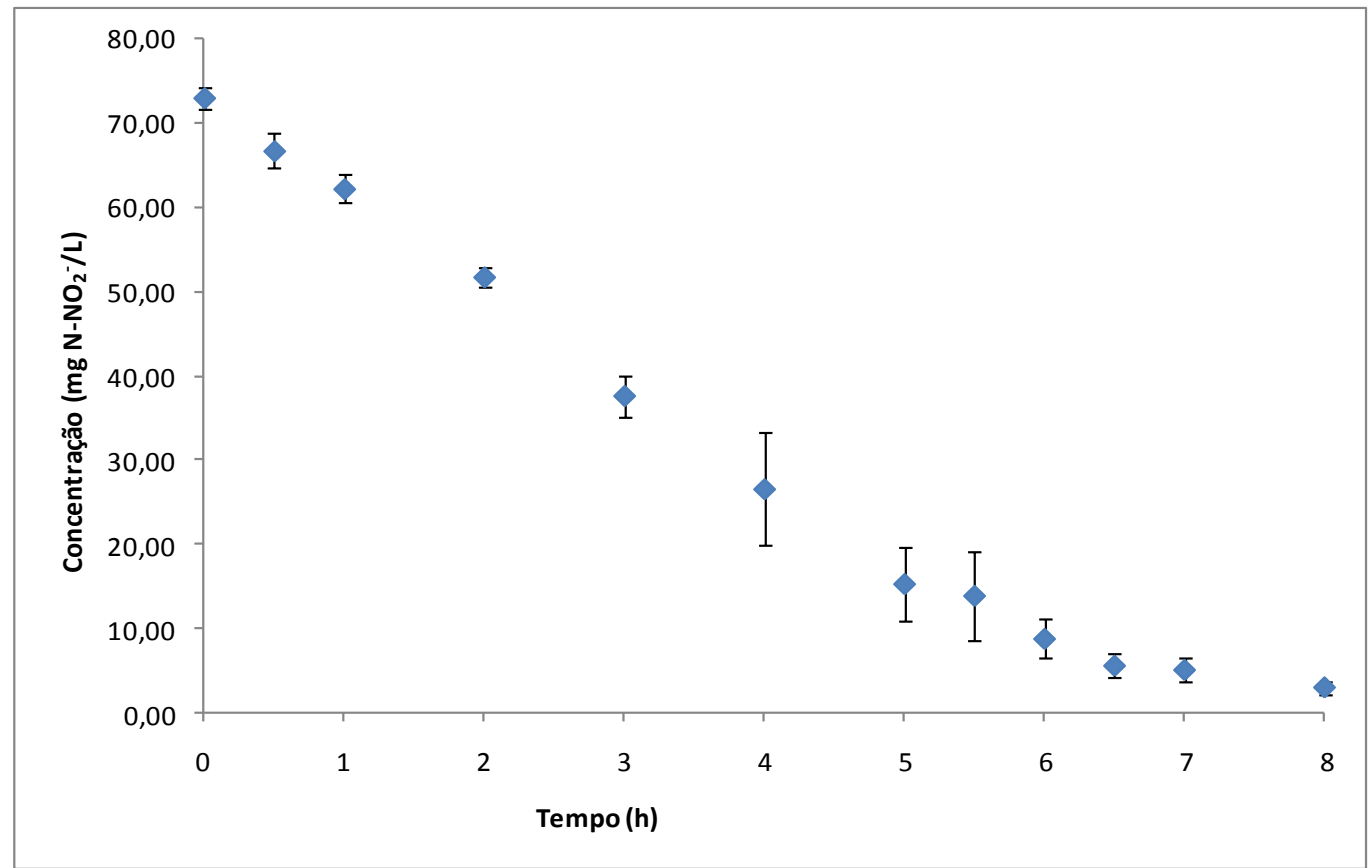

Figura 36. Variação temporal de consumo de nitrito no reator em batelada, sem agitação, do ensaio com $67 \mathrm{mg} \mathrm{N}-\mathrm{NH}_{4}{ }^{+} / \mathrm{L}$ e $73 \mathrm{mg} \mathrm{N}-\mathrm{NO}_{2}{ }^{-} / \mathrm{L}$ : valores médios e desvio padrão 
A Figura 37 mostra o intervalo de ajuste dos parâmetros cinéticos, e pode-se observar que o consumo dos compostos nitrogenados foi constante e linear até a quinta

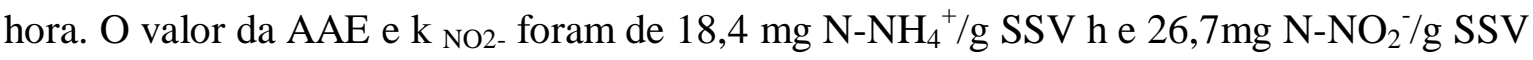
$\mathrm{h}$, respectivamente..

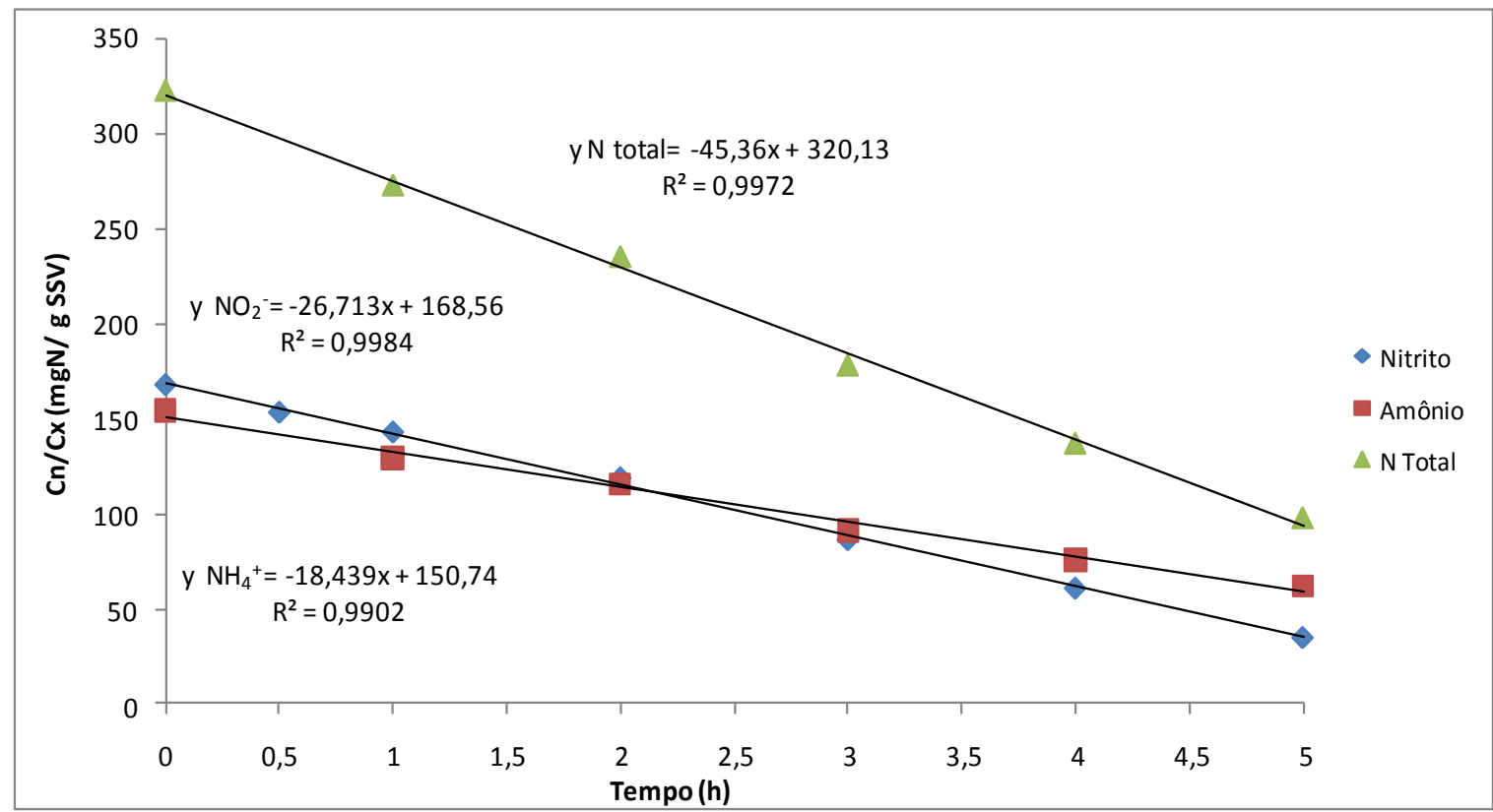

Figura 37. Intervalo de ajuste dos parâmetros cinéticos do ensaio com $67 \mathrm{mg} \mathrm{N}-\mathrm{NH}_{4}{ }^{+} / \mathrm{L} \mathrm{e} 73 \mathrm{mg} \mathrm{N}-$ $\mathrm{NO}_{2}^{-} / \mathrm{L}$, o eixo das ordenadas foi ajustado pela concentração de biomassa (SSV)

O ensaio com valor inicial de amônio e nitrito com $67,3 \mathrm{~N}-\mathrm{NH}_{4}{ }^{+} / \mathrm{L}$ e $92,2 \mathrm{~N}-\mathrm{NO}_{2}{ }^{-}$ $/ \mathrm{L}$, próximas às da relação estequiométrica $\left(1 \mathrm{~mol} \mathrm{~N}-\mathrm{NH}_{4}{ }^{+} / 1,36 \mathrm{~N}-\mathrm{NO}_{2}{ }^{-}\right)$está representado nas Figura 38 e Figura 39 (Ensaio 3). Esse ensaio foi finalizado com 11 horas e pode-se notar que tanto amônio quanto nitrito foram $100 \%$ removidos. A concentração final de

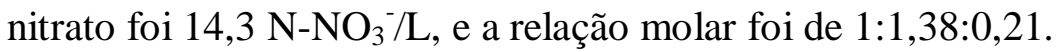




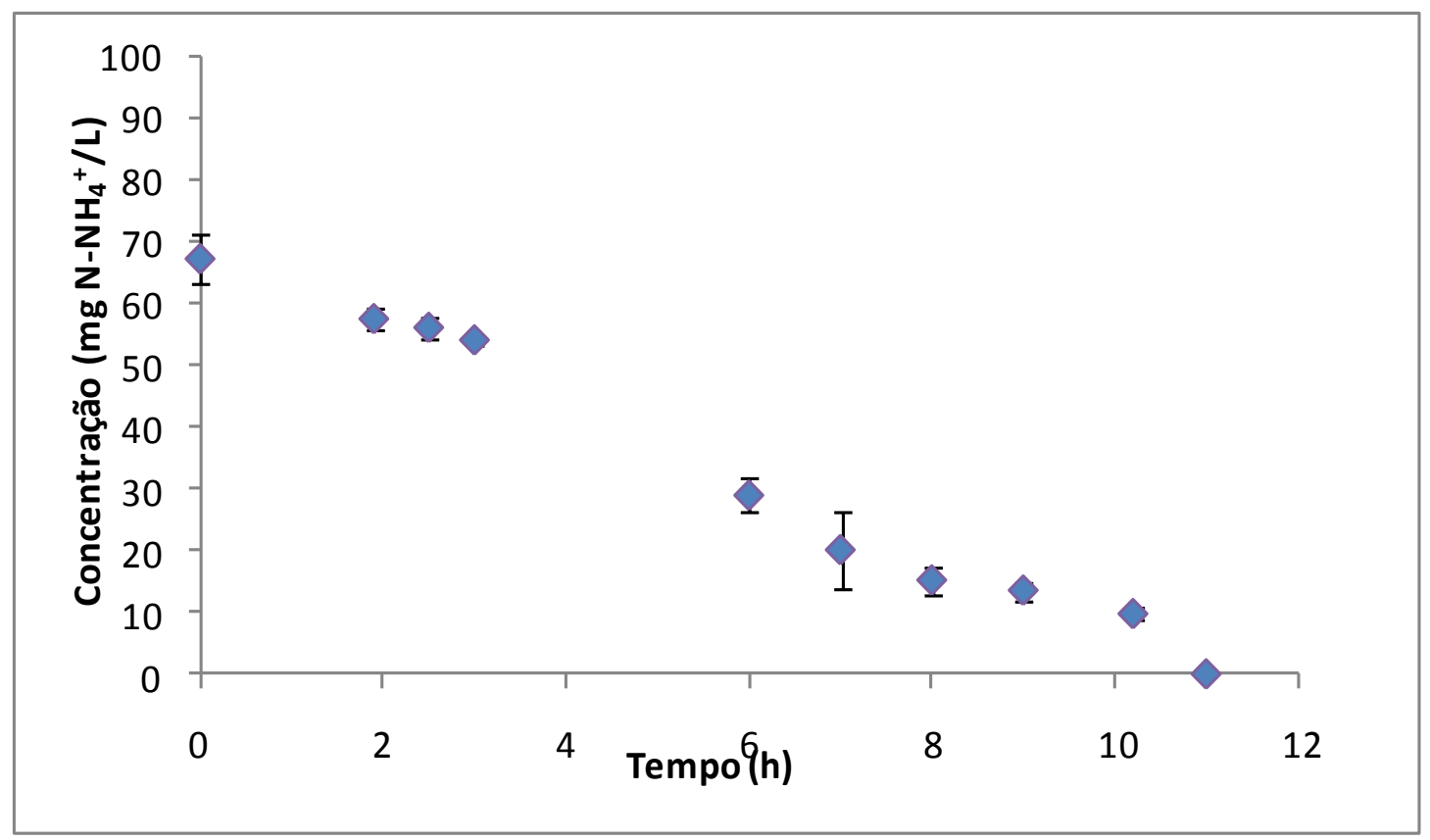

Figura 38. Variação temporal de consumo de amônio no reator em batelada, sem agitação, do ensaio com 67,3 mg N-NH${ }_{4}^{+} / \mathrm{L}$ e 92,2 ${\mathrm{mg} \mathrm{N}-\mathrm{NO}_{2}}^{-} / \mathrm{L}$ : valores médios e desvio padrão

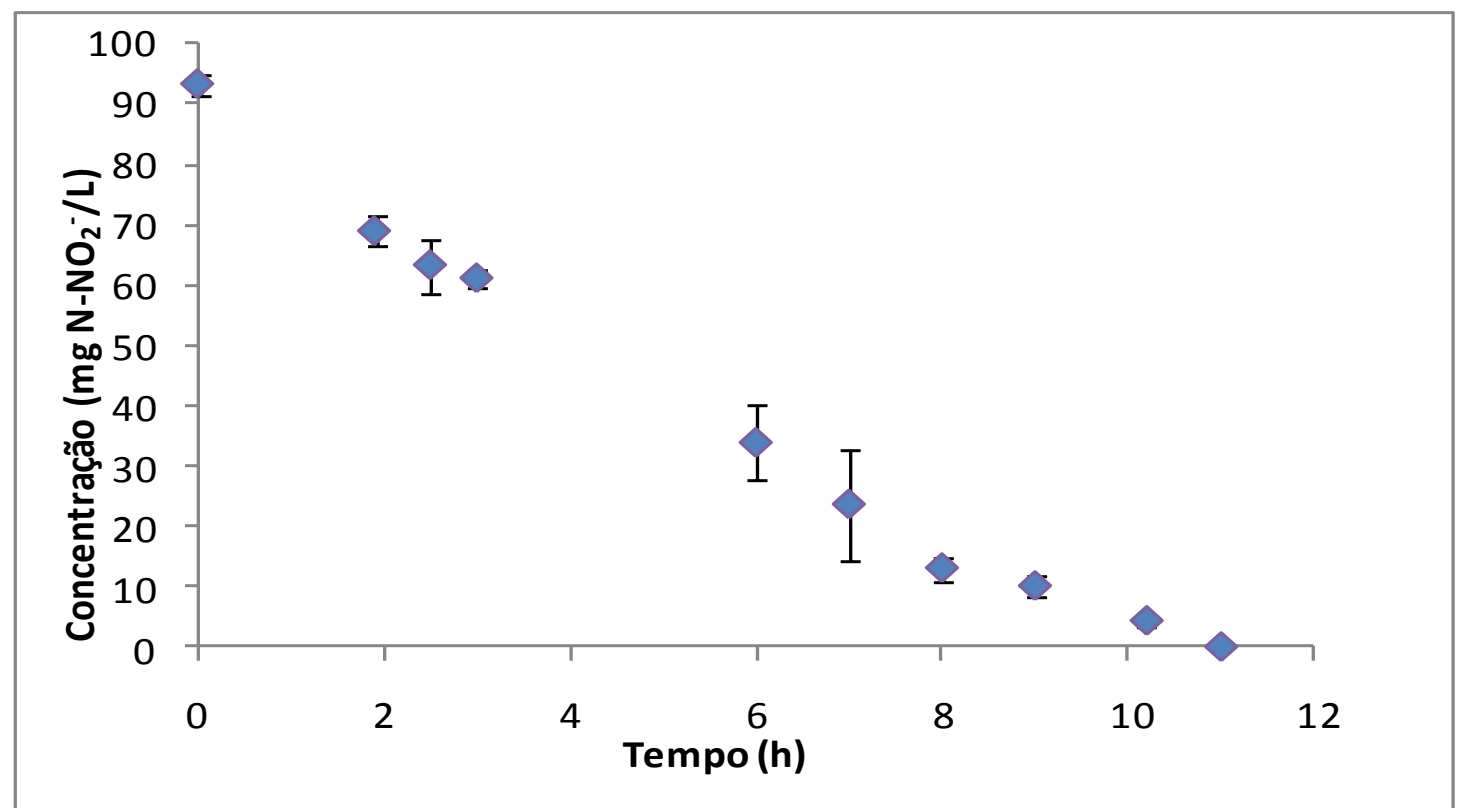

Figura 39. Variação temporal de consumo de nitrito no reator em batelada, sem agitação, do ensaio com 67,3 mg N-NH${ }_{4}^{+} / \mathrm{L}$ e 92,2 mg N-NO ${ }_{2}{ }^{-} / \mathrm{L}$ : valores médios e desvio padrão

O intervalo de ajuste dos parâmetros cinéticos está representado na Figura 38. Pode-se observar que o consumo dos compostos nitrogenados foi constante e linear até a 8 horas. Os valores da AAE e $\mathrm{k}_{\mathrm{NO} 2}$ - nesse ensaio foram de 26,2 $\mathrm{mg} \mathrm{N}^{-\mathrm{NH}_{4}}{ }^{+} / \mathrm{g} \mathrm{SSV} \mathrm{h}$ e 35,9 $\mathrm{mg} \mathrm{N}-\mathrm{NO}_{2}{ }^{-} / \mathrm{g} \mathrm{SSV} \mathrm{h}$, respectivamente. 


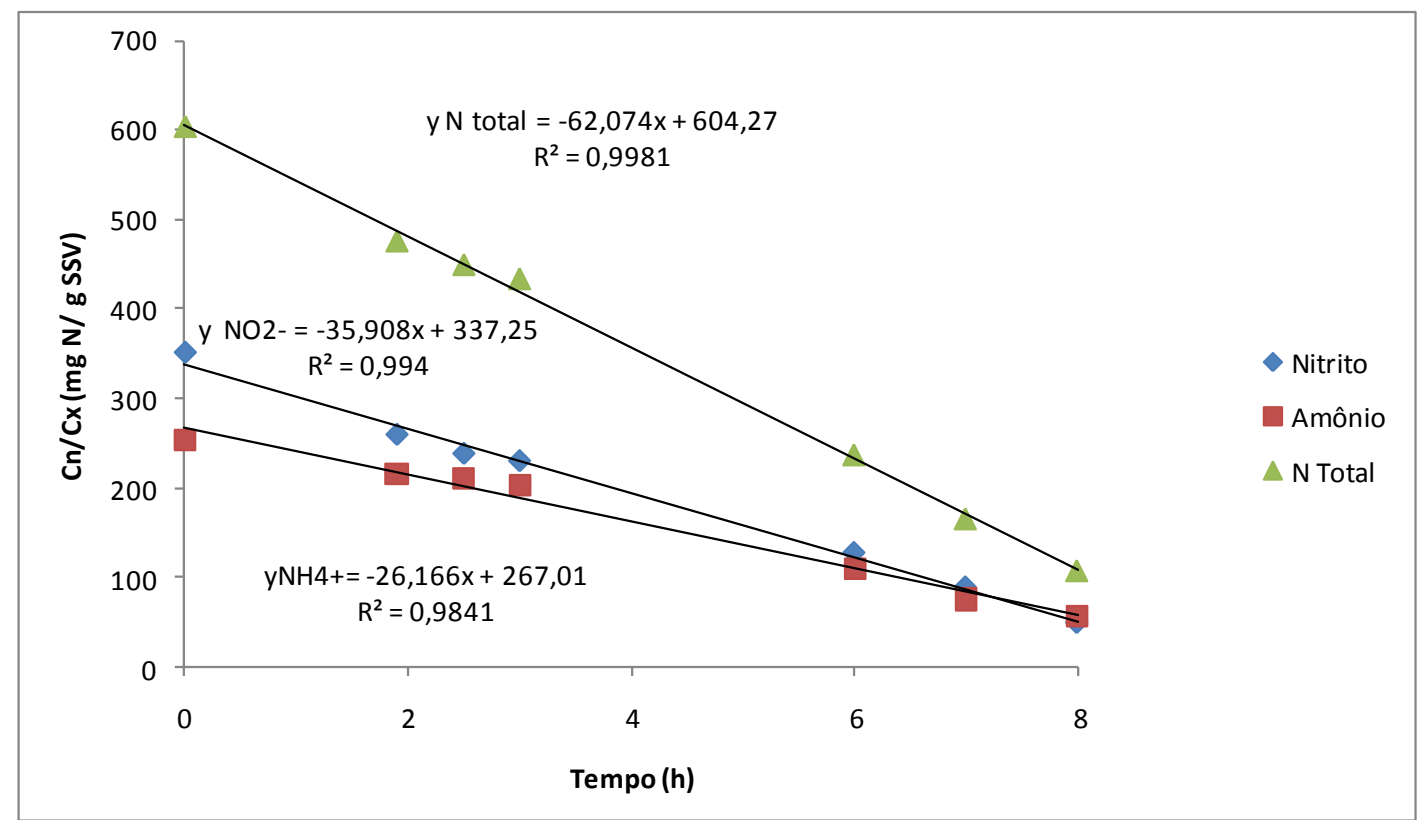

Figura 40. Intervalo de ajuste dos parâmetros cinéticos do ensaio com $67,3 \mathrm{mg} \mathrm{N}-\mathrm{NH}_{4}{ }^{+} / \mathrm{L}$ e 92,2 $\mathrm{mg} \mathrm{N}-\mathrm{NO}_{2}{ }^{-} / \mathrm{L}$, o eixo das ordenadas foi ajustado pela concentração de biomassa (SSV)

Pode-se observar, pela Figura 41, que os valores de AAE e $\mathrm{k}_{\mathrm{NO} 2 \text { - obtidos nos }}$ ensaios 1 e 2 foram próximos, para concentrações iniciais aproximadamente equimolares. Todavia, no ensaio 3, a AAE foi 23 e $30 \%$ maior em relação aquela obtida no ensaio 1 e ensaio 2, respectivamente. Tal constatação indicou que a concentração inicial dos compostos não influenciam na $\mathrm{AAE}$, mas, a proporção entre eles influenciou significativamente na atividade anammox específica, talvez pela biomassa não estar submetida à condição limitante de nitrito, como pode ser observado na Figura 38 e Figura 39 os dois compostos nitrogenados alcançam valores próximos de zero praticamente juntos.

LOPEZ et al. (2008) realizaram processo de Start-up e enriquecimento de biomassa anammox com base no aumento gradual da razão molar afluente de nitrito e amônio (de 0,76 para 1,32) e do aumento exponencial da carga nitrogenada aplicada (de 0,01 a 1,60 $\mathrm{kgN} / \mathrm{m}^{3} \mathrm{~d}$ ). As eficiências de remoção de amônio foram 53, 79 e 99,9\%, para razão de 0,76, 1 e 1,32, respectivamente. No entanto, não foi possível comparar os valores de AAE em função da razão molar dos compostos nitrogenados, pois os autores não obtiveram os valores em termos específicos. 


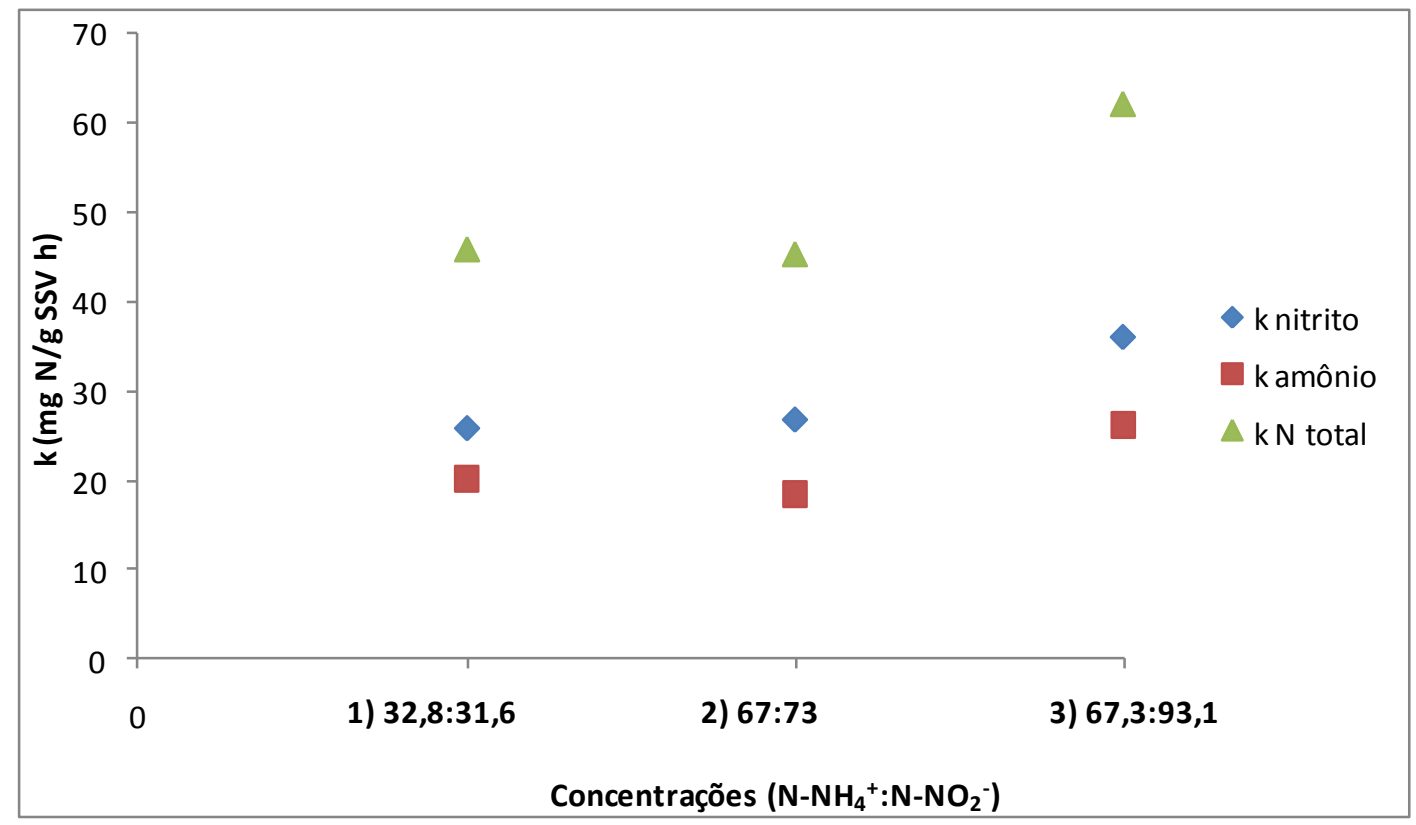

Figura 41. Variação dos parâmetros cinéticos $\mathrm{k}_{\mathrm{NH} 4+}(\mathrm{AAE}), \mathrm{k}_{\mathrm{NO2} 2} \mathrm{e} \mathrm{k}_{\mathrm{N} \text { total }}$ em função da concentração inicial e razão molar afluente

\subsubsection{Influência da Temperatura}

A avaliação da influência da temperatura foi realizada em reatores em bateladas descontínuos e sem agitação. A concentração inicial de cada compostos nitrogenado foi aproximadamente igual ao ensaio 2; ou seja, de $70 \mathrm{mg} / \mathrm{L}$.

A $35^{\circ} \mathrm{C}$ o nitrito foi praticamente removido em 6 horas, restando somente $6,7 \mathrm{mg}$

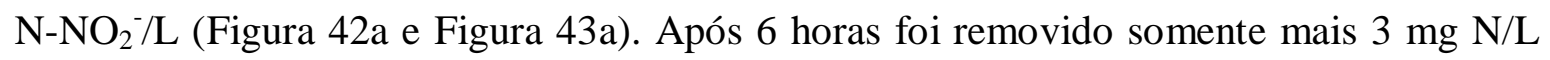
de cada composto nitrogenado. Os valores finais de amônio, nitrito e nitrato foram, respectivamente, $9,9 \mathrm{mg} \mathrm{N}-\mathrm{NH}_{4}{ }^{+} / \mathrm{L}, 2,4 \mathrm{mg} \mathrm{N}-\mathrm{NO}_{2}{ }^{-} / \mathrm{L}$ e $17,4 \mathrm{mg} \mathrm{N}-\mathrm{NO}_{3}{ }^{-} / \mathrm{L}$ (10 horas).

O ensaio a $30^{\circ} \mathrm{C}$ também teve 10 horas de duração, com valores finais de $10 \mathrm{mg} \mathrm{N}$ $\mathrm{NH}_{4}{ }^{+} / \mathrm{L}, 5 \mathrm{mg} \mathrm{N}-\mathrm{NO}_{2}{ }^{-} / \mathrm{L}$ e 13,5 mg N-NO${ }_{3}{ }^{-} / \mathrm{L}$ (Figura 42b e Figura 43 b).

Nos ensaios a 25 e $20^{\circ} \mathrm{C}$ pode-se notar maior inibição da atividade anammox pela baixa temperatura, principalmente a $20^{\circ} \mathrm{C}$ [Figura 42(c $e$ d) e Figura 43 (c $e$ d)]. Esses ensaios finalizaram com 15 horas com remoção de 88 e $55 \%$ de nitrito, 68 e $45 \%$ de amônio, respectivamente, para 25 e $20^{\circ} \mathrm{C}$. 

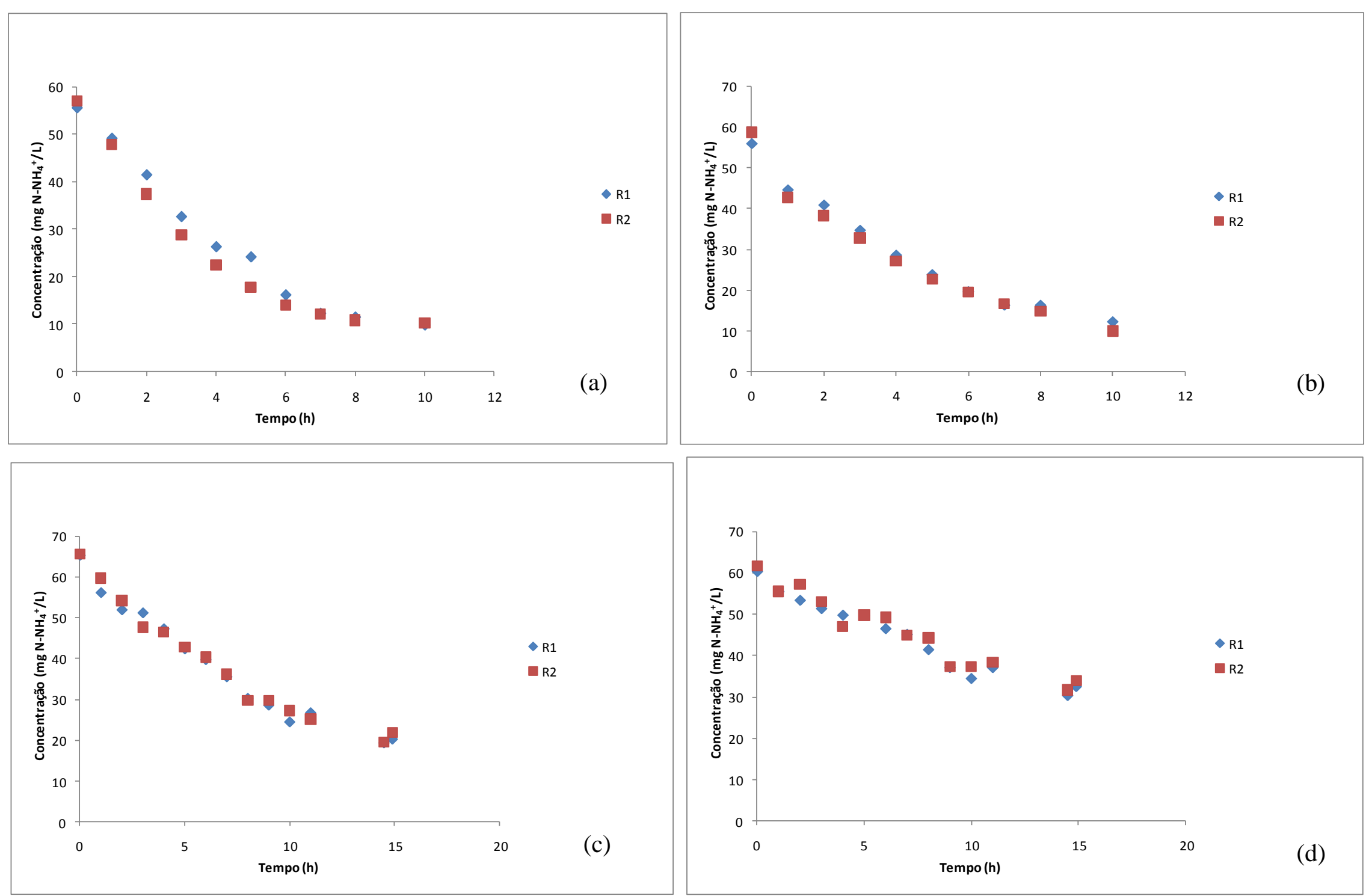

Figura 42. Variação temporal de consumo de amônio em reator em batelada, sem agitação, submetidos a diferentes temperaturas: (a) $35^{\circ} \mathrm{C}$; (b) $30^{\circ} \mathrm{C}$; (c) $25^{\circ} \mathrm{C}$ e (d) $20^{\circ} \mathrm{C}$ 

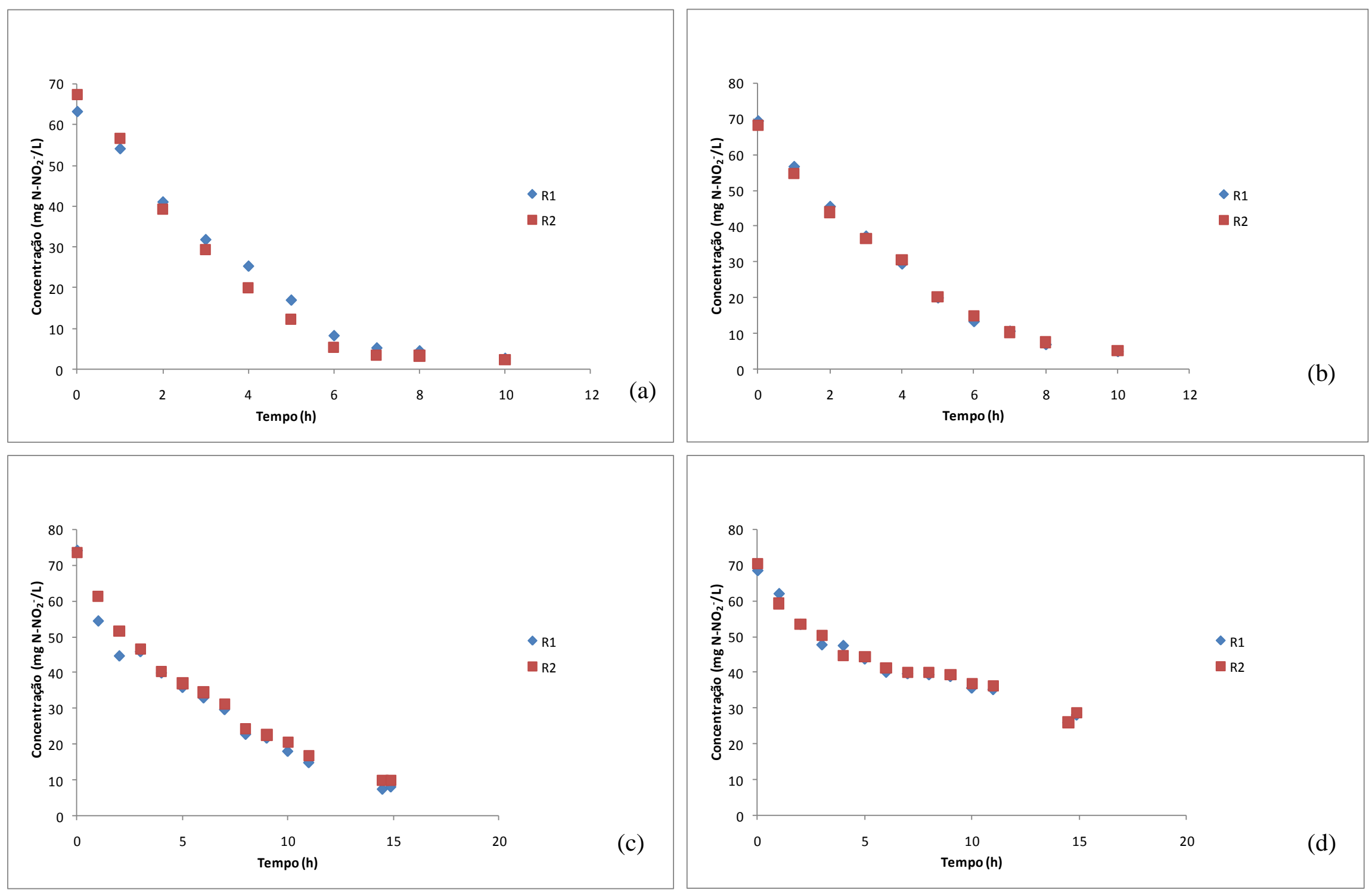

Figura 43. Variação temporal de consumo de nitrito em reator em batelada, sem agitação, submetidos a diferentes temperaturas: (a) $35^{\circ} \mathrm{C}$; (b) $30^{\circ} \mathrm{C}$; (c) $25^{\circ} \mathrm{C}$ e (d) $20^{\circ} \mathrm{C}$ 
Para a temperatura de $20^{\circ} \mathrm{C}$ foi observado melhor ajuste a intervalos mais distantes do início do ensaio (Figura 44). Este fato ocorreu, provavelmente, em função do equilíbrio entre a temperatura da estufa e dos reatores. A biomassa estava à temperatura ambiente (mais elevada) quando incubados.

A atividade anammox específica aumentou linearmente com a temperatura na faixa entre 20 e $35^{\circ} \mathrm{C}$, com valores aumentando de 1,20 para $66{\mathrm{mg} \mathrm{N}-\mathrm{NH}_{4}}^{+} / \mathrm{g} \mathrm{SSV} \mathrm{h}$ (Figura 45). No entanto, ocorreu aumento abrupto da $\mathrm{AAE}$ em $37^{\circ} \mathrm{C}$ (ensaio 2) alcançando valor de $18,4 \mathrm{mg} \mathrm{N}-\mathrm{NH}_{4}{ }^{+} / \mathrm{g} \mathrm{SSV}$ h. Esses valores reforçam aqueles obtidos por STROUS et al., (1999b) e JETTEN et al. (1998) para temperatura ideal entre $37^{\circ} \mathrm{C}$ e $40^{\circ} \mathrm{C}$.

EGLI et al. (2001) realizaram ensaios de AAE nas seguintes temperaturas: 11, 20, $25,30,37$ e $45^{\circ}$ C. A AAE máxima (como taxa de produção de $\mathrm{N}_{2}$ ) foi observada a $37^{\circ} \mathrm{C}$. Nenhuma atividade anammox foi observada a $45^{\circ} \mathrm{C}$, e a atividade não pode ser retomada quando a temperatura foi reduzida para $37^{\circ} \mathrm{C}$. A $11^{\circ} \mathrm{C}$ a AAE foi de aproximadamente $24 \%$ da atividade observada a $37^{\circ} \mathrm{C}$. 

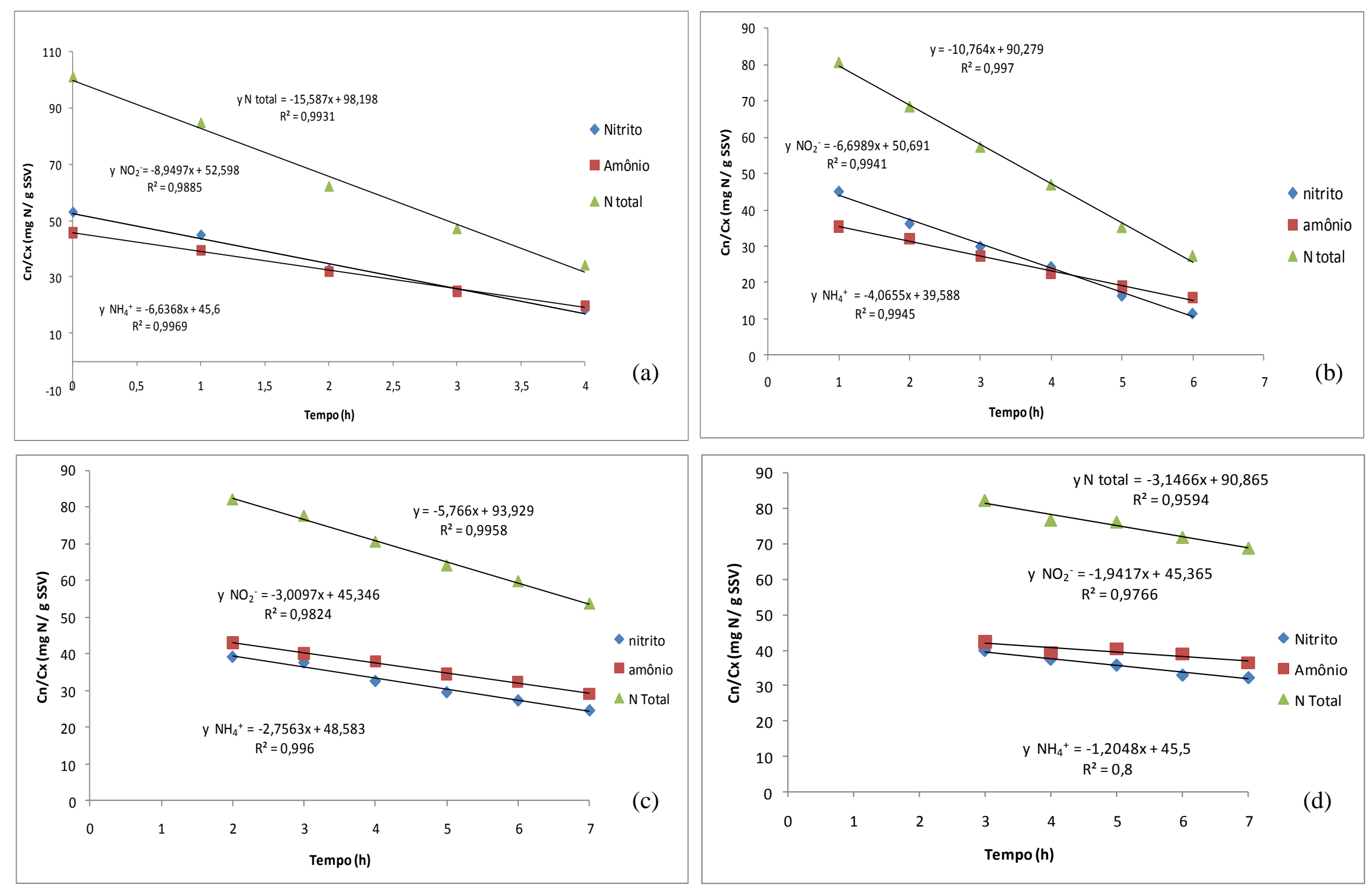

Figura 44. Intervalo de ajuste dos parâmetros cinéticos nos ensaios com diferentes temperaturas: (a) $35^{\circ} \mathrm{C}$; (b) $30^{\circ} \mathrm{C}$; (c) $25^{\circ} \mathrm{C}$ e (d) $20^{\circ} \mathrm{C}$. O eixo das ordenadas foi ajustado pela concentração de biomassa (SSV) 
STROUS et al. (1997b) estudaram o processo anammox para efluentes de digestor de lodo. Experimentos preliminares indicaram que a biomassa não foi inibida pelas características do efluente. A temperatura de $37^{\circ} \mathrm{C}$ e $\mathrm{pH} 8$ foram os valores ótimos para a biomassa anammox. Nesses ensaios fisiológicos a atividade anammox específica (AAE) foi de 0,58 $\mathrm{mg} \mathrm{N}-\mathrm{NH}_{4}{ }^{+} / \mathrm{g} \mathrm{SSV} \mathrm{h}$; ou seja, cinco vezes menor do que a AAE da mesma biomassa em reator.

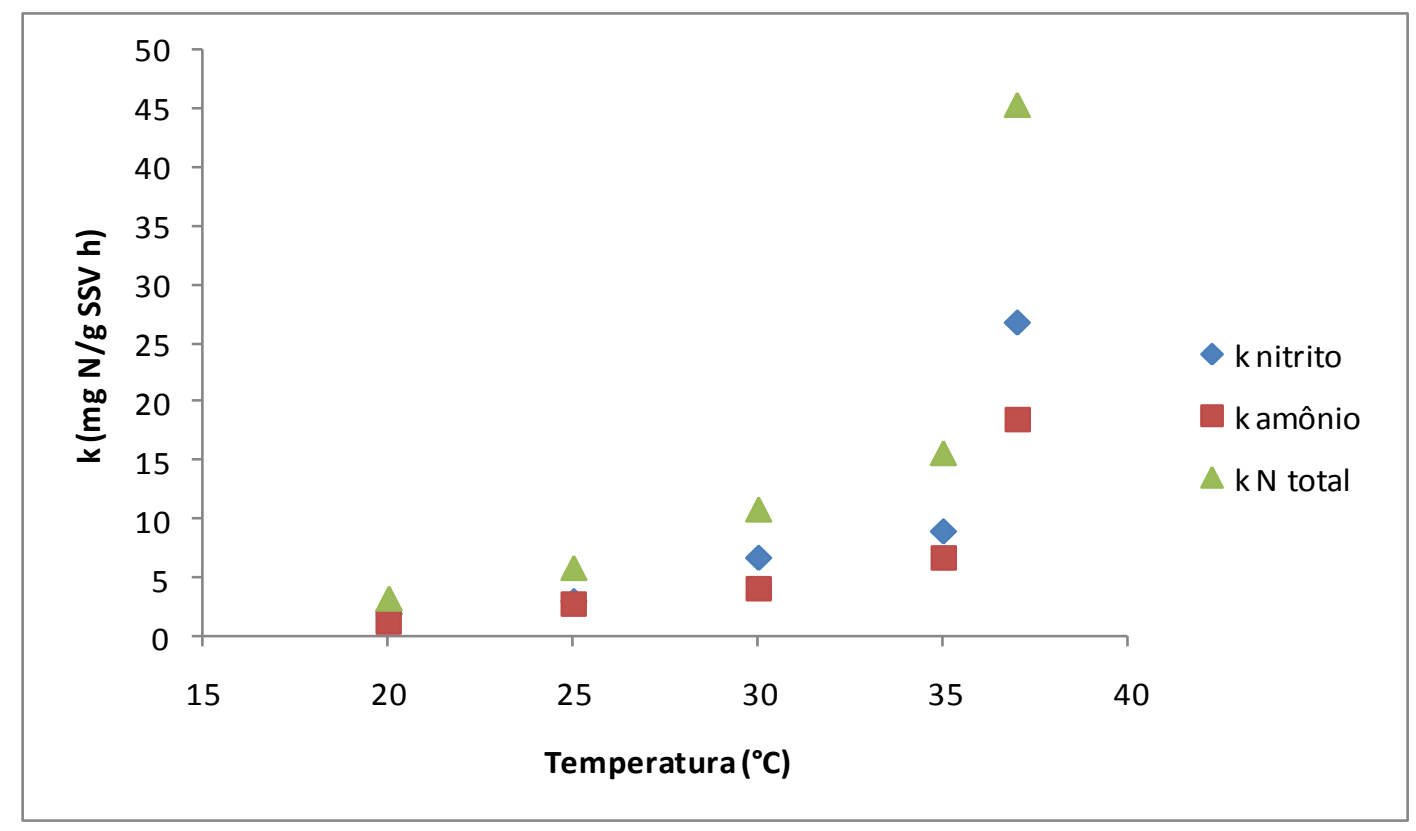

Figura 45. Comparação dos parâmetros cinéticos específicos em função da temperatura

Nesta pesquisa, foram denominados dois valores de anammox específica máxima (AAEM): (1) 26,2 $\mathrm{mg} \mathrm{N}^{-\mathrm{NH}_{4}}{ }^{+} / \mathrm{g} \mathrm{SSV}$ h, no ensaio 3 (batelada descontínuo), e (2) 33,5 mg $\mathrm{N}-\mathrm{NH}_{4}{ }^{+} / \mathrm{g} \mathrm{SSV}$ h, no ensaio no RBS com freqüência de agitação de $50 \mathrm{rpm}$. A atividade anammox específica máxima (AAEM) foi menor nos ensaios em batelada descontínuos em relação à encontrada no RBS. Segundo STROUS et al. (1997b), a razão para a baixa atividade em experimentos com reatores em batelada descontínuos permanece desconhecida.

A Tabela 12 apresenta uma compilação de dados de AAE de diversos trabalhos encontrados na literatura. $\mathrm{O}$ valor de $\mathrm{AAE}$ encontrado nessa pesquisa foi de $43 \%$ do valor encontrado por JETTEN et al.(1998). No entanto, o valor da AAE de 33,5 $\mathrm{mg} \mathrm{N}^{-\mathrm{NH}_{4}}{ }^{+} / \mathrm{g}$ SSV h obtida no ensaio 3 foi superior ou próximo à maioria dos dados encontrados. 
Tabela 12. Valores de atividade anammox específica encontrados por outros autores

\begin{tabular}{|c|c|c|c|}
\hline $\begin{array}{c}\text { Atividade anammox } \\
\text { específica }\end{array}$ & Reator & $\begin{array}{c}\text { Temperatura } \\
\left({ }^{\circ} \mathrm{C}\right)\end{array}$ & Referência \\
\hline$\left(\mathrm{mg} \mathrm{N}-\mathrm{NH}_{4}{ }^{+} / \mathrm{g} \mathrm{SSV} \mathrm{h}\right)$ & & & \\
\hline 0,104 & Batelada & 37 & VAN DE GRAAF et al. (1995) \\
\hline 1,125 & RBS & 36 & MULDER et al. (1995) \\
\hline 1,68 & RBS & 32 & STROUS et al. (1997a) \\
\hline 3,33 & Leito fluidizado & 36 & STROUS et al. (1997b) \\
\hline 0,58 & Batelada & 34 & \\
\hline $63^{\mathrm{a}}$ & RBS 80 rpm & 33 & STROUS et al. (1998) \\
\hline $77^{\mathrm{a}}$ & Batelada & 40 & JETTEN et al. (1998) \\
\hline $35^{\mathrm{a}}$ & Batelada & & STROUS et al. (1999a) \\
\hline $37,1^{\mathrm{a}, \mathrm{b}}$ & Batelada & 37 & EGLI et al. (2001) \\
\hline 3,18 & Batelada & 29 & PYNAERT et al. (2003) \\
\hline 47,91 & Gas-lift & 30 & DAPENA-MORA et al. (2004a) \\
\hline 27,08 & RBS 70 rpm & & \\
\hline 7,5 & RBS 50rpm & 35 & DAPENA-MORA et al. (2004b) \\
\hline 3,54 & RBS & 35 & KIELING et al. (2005) \\
\hline 3,64 & RBS $50 \mathrm{rpm}$ & 35 & THIRD et al. (2005) \\
\hline $18,33^{\mathrm{b}}$ & Batelada & 35 & DAPENA-MORA et al. (2006) \\
\hline $16,67^{\mathrm{b}}$ & RBS 60-180rpm & 30 & ARROJO et al.(2006) \\
\hline $10,41^{\mathrm{b}}$ & RBS $250 \mathrm{rpm}$ & 30 & ARROJO et al. (2006) \\
\hline 66,67 & Leito fixo & 37 & TSUSHIMA et al. (2007) \\
\hline 33,5 & RBS 50 rpm & 37 & Esse trabalho \\
\hline 26,2 & $\begin{array}{c}\text { Batelada } \\
\text { descontínuo }\end{array}$ & 37 & Esse trabalho \\
\hline
\end{tabular}

${ }^{\text {a }} \mathrm{O}$ valor da biomassa no artigo original foi dado em proteína, e foi convertida em SSV pelo fator 0,6g proteína $=1 \mathrm{~g} \mathrm{SSV}$ (STROUS et al., 1998; AHN, 2006)

${ }^{\mathrm{b}} \mathrm{O}$ nitrogênio foi expresso em $\mathrm{N}-\mathrm{N}_{2}$ 


\subsection{OPERAÇÃO DO REATOR DE LEITO FIXO}

O Reator de Leito Fixo (RLF) foi inoculado com a biomassa enriquecida no reator operado em bateladas sequenciais (RBS). Essa biomassa foi retirada do RBS após 232 dias de operação. Foi inoculado volume de $1.150 \mathrm{~mL}$ de biomassa em suspensão $(0,75$ gSSV/L), totalizando 0,86g SSV inoculado em meio de cultivo van de GRAAF, com 70 $\mathrm{mg} / \mathrm{L}$ de amônio e $80 \mathrm{mg} / \mathrm{L}$ de nitrito. Nessa fase, manteve-se a alimentação em circuito fechado durante 4 dias (Figura 46). O RLF foi operado durante 257 dias e as condições de operação estão representadas na Tabela 13.

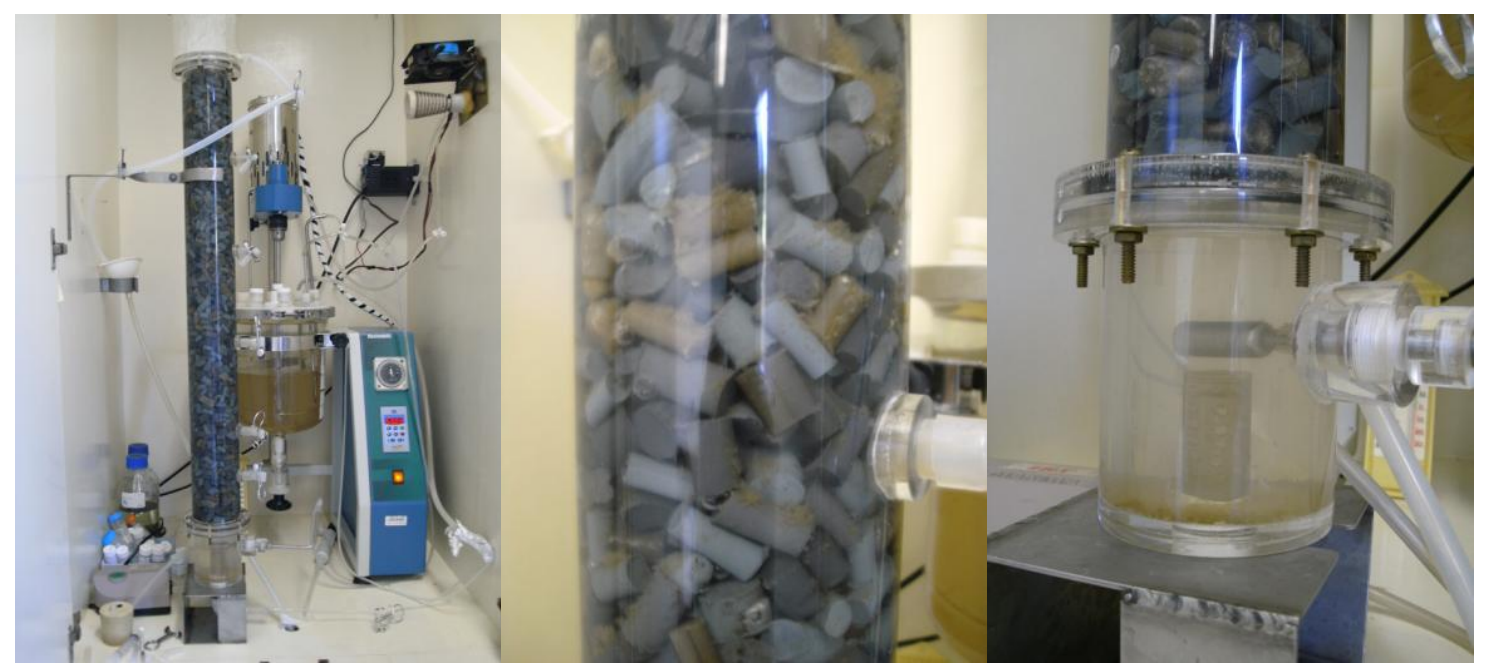

Figura 46. Reator de Leito Fixo após a inoculação, detalhes do leito e entrada do reator

Tabela 13. Etapas de operação do Reator de Leito Fixo

\begin{tabular}{|c|c|c|}
\hline Etapa & Condição & Período \\
\hline 1 & $\begin{array}{l}70,6 \pm 2,4 \mathrm{mg} \mathrm{N}^{-\mathrm{NH}_{4}}{ }^{+} / \mathrm{L} \\
84,1 \pm 3,2 \mathrm{mg} \mathrm{N}-\mathrm{NO}_{2}^{-} / \mathrm{L}\end{array}$ & $1-16^{\circ}$ dia \\
\hline 2 & $\begin{array}{l}144,4 \pm 6,2{\mathrm{mg} \mathrm{N}-\mathrm{NH}_{4}}^{+} / \mathrm{L} \\
180,7 \pm 2,9 \mathrm{mg} \mathrm{N}-\mathrm{NO}_{2}-/ \mathrm{L}\end{array}$ & $17-52^{\circ} \mathrm{dia}$ \\
\hline 3 & $\begin{array}{l}213,5 \pm 6,7 \mathrm{mg} \mathrm{N}^{-\mathrm{NH}_{4}}{ }^{+} / \mathrm{L} \\
248,7 \pm 8,9 \mathrm{mg} \mathrm{N}-\mathrm{NO}_{2}-/ \mathrm{L}\end{array}$ & $53-103^{\circ}$ dia \\
\hline 4 & $\begin{array}{l}303,3 \pm 11,8 \mathrm{mg} \mathrm{N}-\mathrm{NH}_{4}{ }^{+} / \mathrm{L} \\
364,7 \pm 7,3 \mathrm{mg} \mathrm{N}-\mathrm{NO}_{2}-/ \mathrm{L}\end{array}$ & $103-139^{\circ} \mathrm{dia}$ \\
\hline Nitrificante/ anammox & $111,5 \pm 6,7 \mathrm{mg} \mathrm{N}^{-\mathrm{NH}_{4}}{ }^{+} / \mathrm{L}$ & $140-200^{\circ} \mathrm{dia}$ \\
\hline 5 & $\begin{array}{l}97,7 \pm 2,9 \mathrm{mg} \mathrm{N}-\mathrm{NH}_{4}^{+} / \mathrm{L} \\
125 \pm 4,7 \mathrm{mg} \mathrm{mg} \mathrm{N}-\mathrm{NO}_{2}{ }^{-} / \mathrm{L}\end{array}$ & $201-234^{\circ} \mathrm{dia}$ \\
\hline 6 & $\begin{array}{l}187,7 \pm 2{\mathrm{mg} \mathrm{N}-\mathrm{NH}_{4}}^{+} / \mathrm{L} \\
221,5 \pm 2,8 \mathrm{mg} \mathrm{N}^{-\mathrm{NO}_{2}}-\mathrm{L}\end{array}$ & $235-257^{\circ} \mathrm{dia}$ \\
\hline
\end{tabular}


Em virtude de o RLF ter sido inoculado com biomassa anammox, praticamente não apresentou tempo de partida como pode ser verificado na Figura 47. O pH efluente manteve-se estável entre 7,1 e 7,9 durante as etapas 1 a 4 (139 dias).

A carga nitrogenada aplicada aumentou de 154,8 $\pm 2,23 \mathrm{~g} \mathrm{~N} / \mathrm{m}^{3}$ dia para $668,0 \pm 12,8$ g N/m dia entre as etapas 1 a 4, com remoção de 87,9 $\pm 6,8$ e 89,5 $\pm 2,2 \%$, respectivamente. Entre os dias 81 a 88, ocorreu decréscimo da eficiência de remoção de nitrogênio (assinalado em vermelho na Figura 47). Durante este período foi verificado que o frasco de alimentação armazenado em refrigerador a $4^{\circ} \mathrm{C}$ apresentava coloração castanhoalaranjada, provavelmente, devido à solução I (sulfato ferroso e EDTA) do meio van de GRAAF estar velha e do íon férrico ter precipitado. Portanto, foi preparada nova solução e foi restabelecido o processo.

Entre os dias 98 a 100 (assinalado em azul na Figura 47), também foi verificada perda de eficiência de remoção, mas, neste caso, foi por entupimento da pedra porosa com fluxo de gás Argônio/ $\mathrm{CO}_{2}$, causando inibição pela presença de oxigênio no leito do reator. No entanto, logo após o fluxo normal de gás, o processo foi restabelecido, sem adição de intermediários metabólicos (eg. hidrazina) conforme propuseram STROUS et al (1997a).

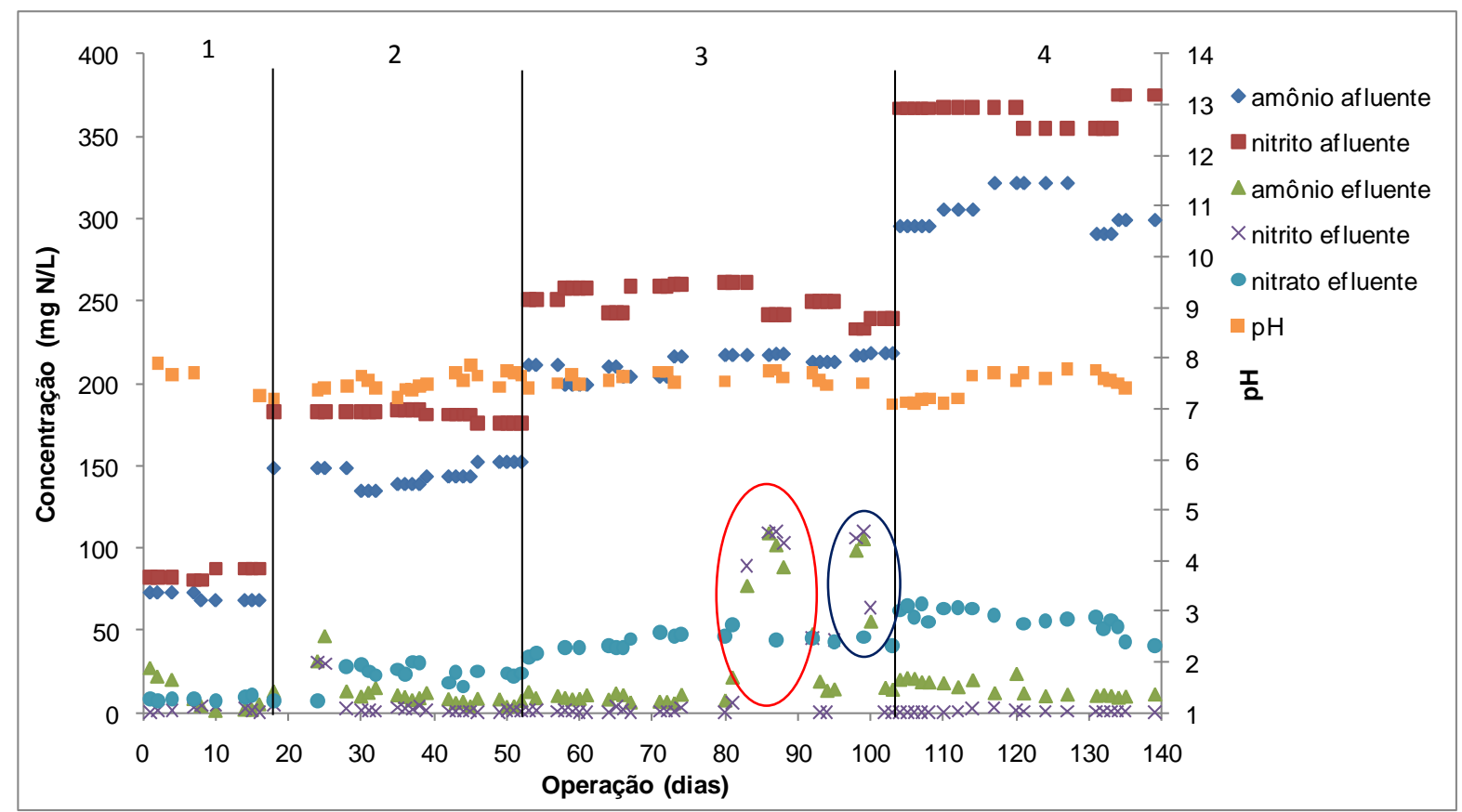

Figura 47. Variação temporal dos compostos nitrogenados e pH durante as etapas 1 a 4 de operação do Reator de Leito fixo 
A Figura 48 mostra a colonização do meio suporte, parede do reator e pedra porosa do RLF no final da etapa 4. Pode-se observar a intensa coloração vermelha da biomassa. Tal característica refere-se, provavelmente, ao elevado conteúdo de citocromos das bactérias anammox (JETTEN et al., 1998).

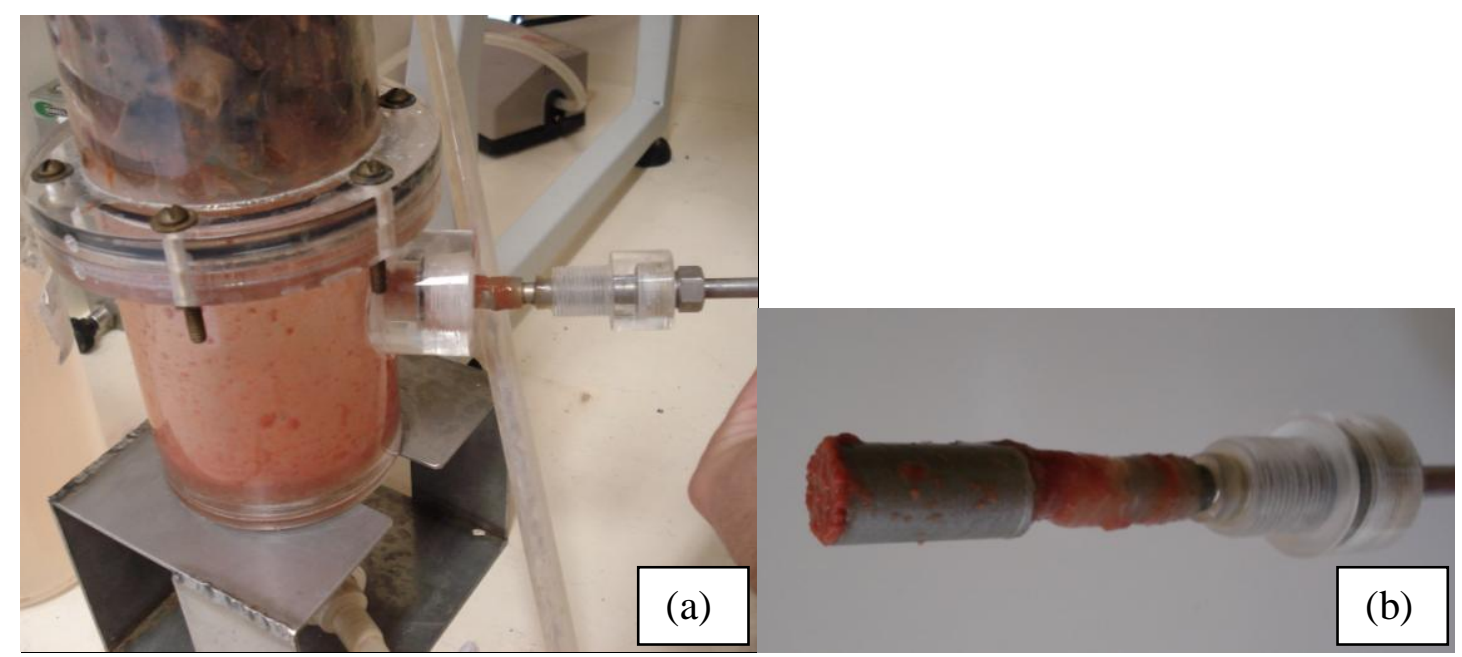

Figura 48. Reator de Leito Fixo no final de operação da etapa 4 (139 dias de operação): (a) entrada do RLF; (b) detalhe da biomassa anammox aderida na pedra porosa

A operação do RLF em condições de nitrificação/anammox foi o teste da segunda parte da hipótese desta tese. Para tanto, ao leito do RLF foi adicionado $400 \mathrm{~mL}$ de lodo ativado da indústria Volkswagen (São Carlos-SP) com 2,17g SSV/L totalizando 0,86 g SSV adicionados ao leito. Antes da inoculação dessa biomassa, o reator foi esvaziado. A biomassa foi adicionada pela abertura na extremidade superior do reator, sendo o restante do volume reacional preenchido com meio van de GRAAF, contendo aproximadamente $110{\mathrm{mg} \mathrm{N}-\mathrm{NH}_{4}}^{+} / \mathrm{L}$, sem nitrito. Nessa etapa, também foi iniciada aeração do RLF.

Após 7 dias de operação nessa nova etapa, a biomassa do reator, que se apresentava avermelhada, foi mudando de coloração para marrom escuro.

Após o $171^{\circ}$ dia (trigésimo primeiro dia dessa etapa de operação), o pH efluente do RLF decresceu para valores próximos de 5. A eficiência de remoção até este momento era $23,8 \%$, enquanto a de conversão de nitrogênio afluente em nitrito, nitrato e gás nitrogênio era de 58,2\%. Todavia, com o decréscimo dos valores de $\mathrm{pH}$, a eficiência de remoção reduziu para 14,2\% e a de conversão elevou-se para 64,7\%; ou seja, o reator teve mudança para comportamento nitrificante. Nessa etapa, o aumento da concentração de oxigênio dissolvido implicou em aumento da concentração de nitrato efluente (Figura 49). Por exemplo, no $189^{\circ}$ dia a concentração de oxigênio dissolvido foi $0,8 \mathrm{mg}$ OD/L e 39,3 mg N- 
$\mathrm{NO}_{3}{ }^{-} / \mathrm{L}$, já no 197 os valores foram 2,9 mg OD/L 74,3 mg N-NO${ }_{3}{ }^{-} / \mathrm{L}$.

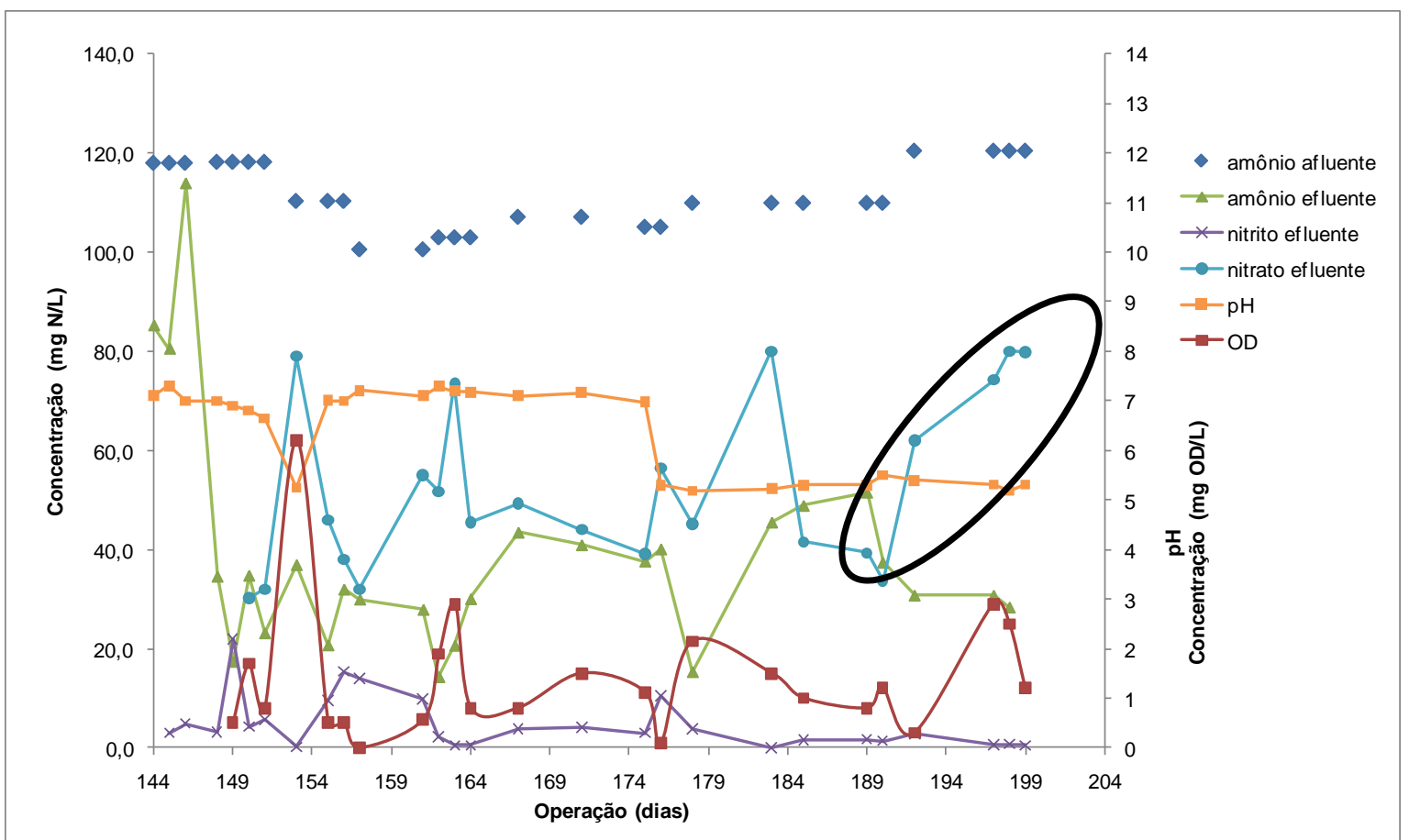

Figura 49. Variação temporal dos compostos nitrogenados, oxigênio dissolvido e $\mathrm{pH}$ durante a etapa de nitrificação/anammox de operação do Reator de Leito Fixo

Após 55 dias de operação da etapa nitrificante/anammox, o RLF voltou a ser operado sob condições anammox com aumento da carga nitrogenada aplicada de 221 para $409 \mathrm{mg} \mathrm{N} / 1$ dia . Após 19 dias, ou seja, entre os dias 200 e 219 de operação, a atividade anammox foi restabelecida completamente, novamente, sem adição de intermediários metabólicos (Figura 50). O pH novamente retornou a patamares próximos de 8 , os quais são ideais para anammox.

Pode-se observar nitidamente na Figura 51, após 50 dias do retorno às condições anammox, (251 dias de operação) a recolonização das bactérias anammox na entrada e leito do RLF, inclusive com produção de gás Figura 51 (b). 


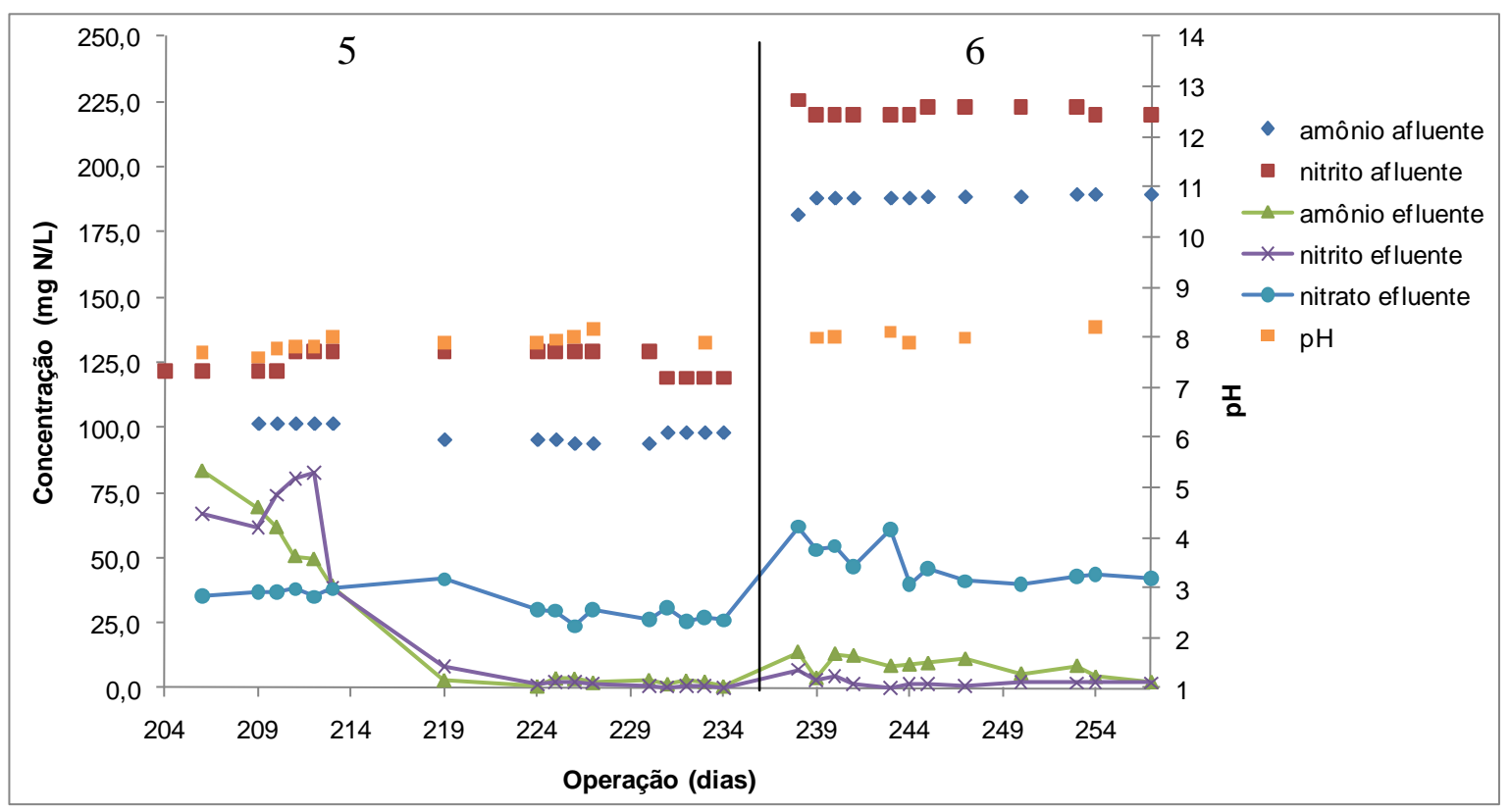

Figura 50. Variação temporal de compostos nitrogenados e pH durante as etapas 5 e 6 de operação do Reator de Leito fixo

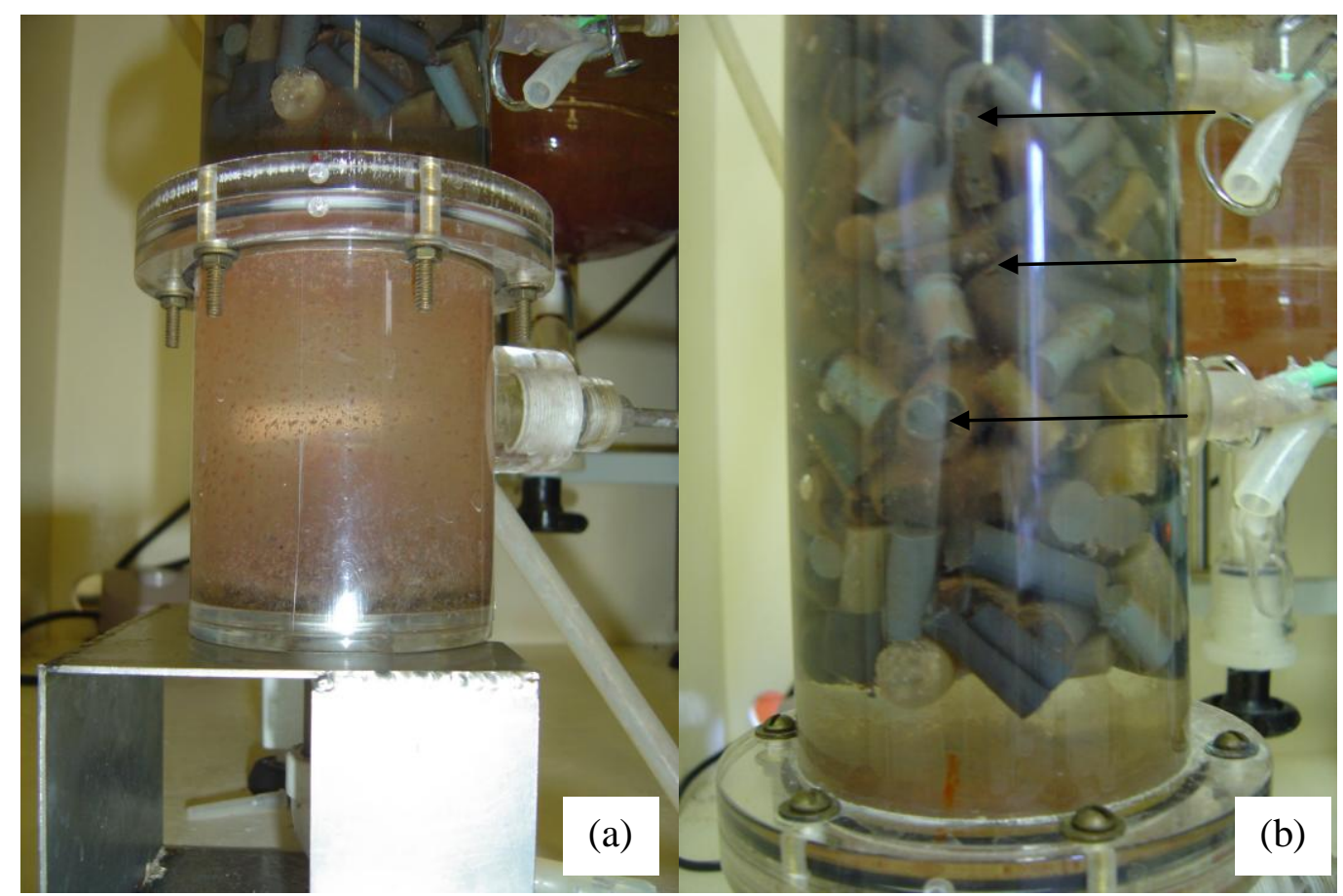

Figura 51. Reator de Leito fixo com 251 dias de operação $\left(50^{\circ}\right.$ dia depois que retornou às condições anammox): (a) base do RLF; (b) detalhe do leito com bolhas de gás $\left(\mathrm{N}_{2}\right)$

O aumento da CNA (carga nitrogenada aplicada) foi acompanhado pela carga nitrogenada removida (Figura 52). Foram realizados perfis espaciais de concentração ao final de todas as etapas de operação do RLF (dados não apresentados). Em todos estes perfis a concentração de nitrito estava próxima de zero no primeiro ou segundo pontos de amostragens, C/D 1 e 2 , respectivamente. 


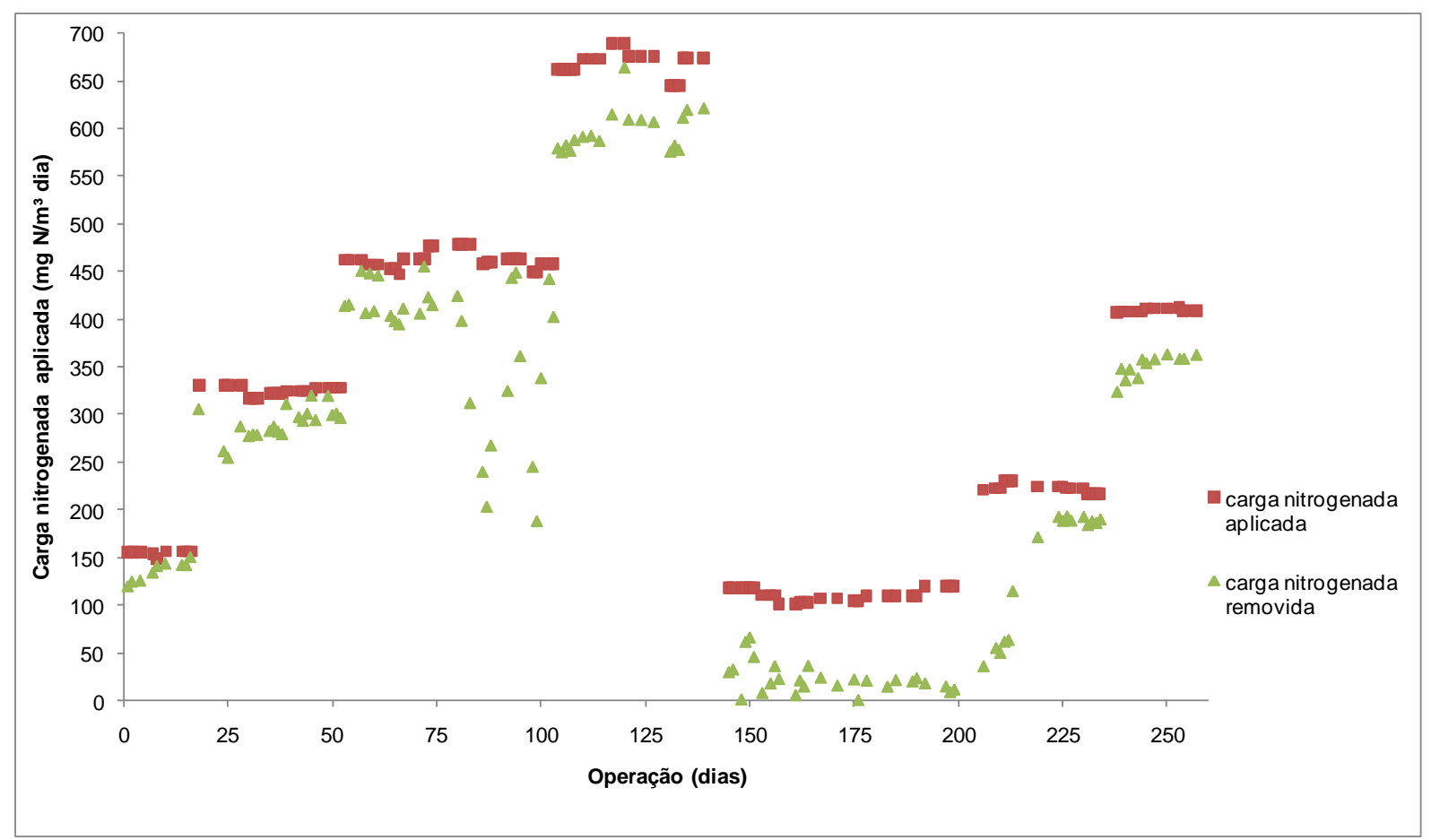

Figura 52. Carga nitrogenada aplicada e removida durante toda operação do RLF

Pode se observar, pela Tabela 14, que o nitrito foi o composto nitrogenado limitante, ou seja, com valores de remoção próximos de 100\%, exceto durante as Etapas 3 e 5, em que ocorreram problemas operacionais descritos anteriormente. Os valores de remoção de nitrito foram entre $97,5 \%$ a $99,7 \%$.

O valor máximo de remoção do amônio foi de $95 \%$ durante as Etapas 4 e 6 . A Figura 53 mostra que a relação molar de nitrato produzido nessas etapas foi abaixo do esperado $(0,26)$. A configuração do reator com biomassa aderida pode ter criado condições para que as bactérias anammox realizassem, também, a rota desnitrificante conforme mencionado por KARTAL et al. (2007a). Este desvio de rota metabólica é muito interessante do ponto de vista biotecnológico, pois o efluente do reator apresenta menor concentração de nitrogênio e, portanto, maior eficiência de remoção.

Os valores da relação molar de nitrato formado no RLF foram entre 0,14 e 0,22 para as Etapas 1 e 3, respectivamente. Pode se observar pela Figura 53 que, geralmente, a relação molar durante a operação do RLF, foi abaixo do previsto estequiometricamente por STROUS et al. (1998) (0,26 mol N-NO$\left.{ }_{3}{ }^{-} / \mathrm{N}_{-} \mathrm{NH}_{4}{ }^{+}\right)$, diferentemente do que ocorreu no RBS (onde os valores oscilaram em torno do valor previsto). 
Tabela 14. Valores de remoção de amônio e nitrito durante as etapas anammox de operação do

\begin{tabular}{ccc}
\multicolumn{3}{c}{ RLF } \\
\hline Etapa & $\begin{array}{c}\text { Remoção de } \mathrm{N}^{-\mathrm{NH}_{4}}{ }^{+} \\
(\%)\end{array}$ & $\begin{array}{c}\text { Remoção de } \mathrm{N}^{-\mathrm{NO}_{2}}{ }^{-} \\
(\%)\end{array}$ \\
\hline 1 & $86,16 \pm 13,7 \%$ & $97,5 \pm 1,7 \%$ \\
2 & $92 \pm 6,6 \%$ & $97,6 \pm 4,8 \%$ \\
3 & $85,7 \pm 16,4 \%$ & $88,9 \pm 17,7 \%$ \\
4 & $95 \pm 1,6 \%$ & $99,7 \pm 0,2 \%$ \\
5 & $76,7 \pm 29,5 \%$ & $79 \pm 27,1 \%$ \\
6 & $95,5 \pm 2 \%$ & $98,9 \pm 0,8 \%$
\end{tabular}

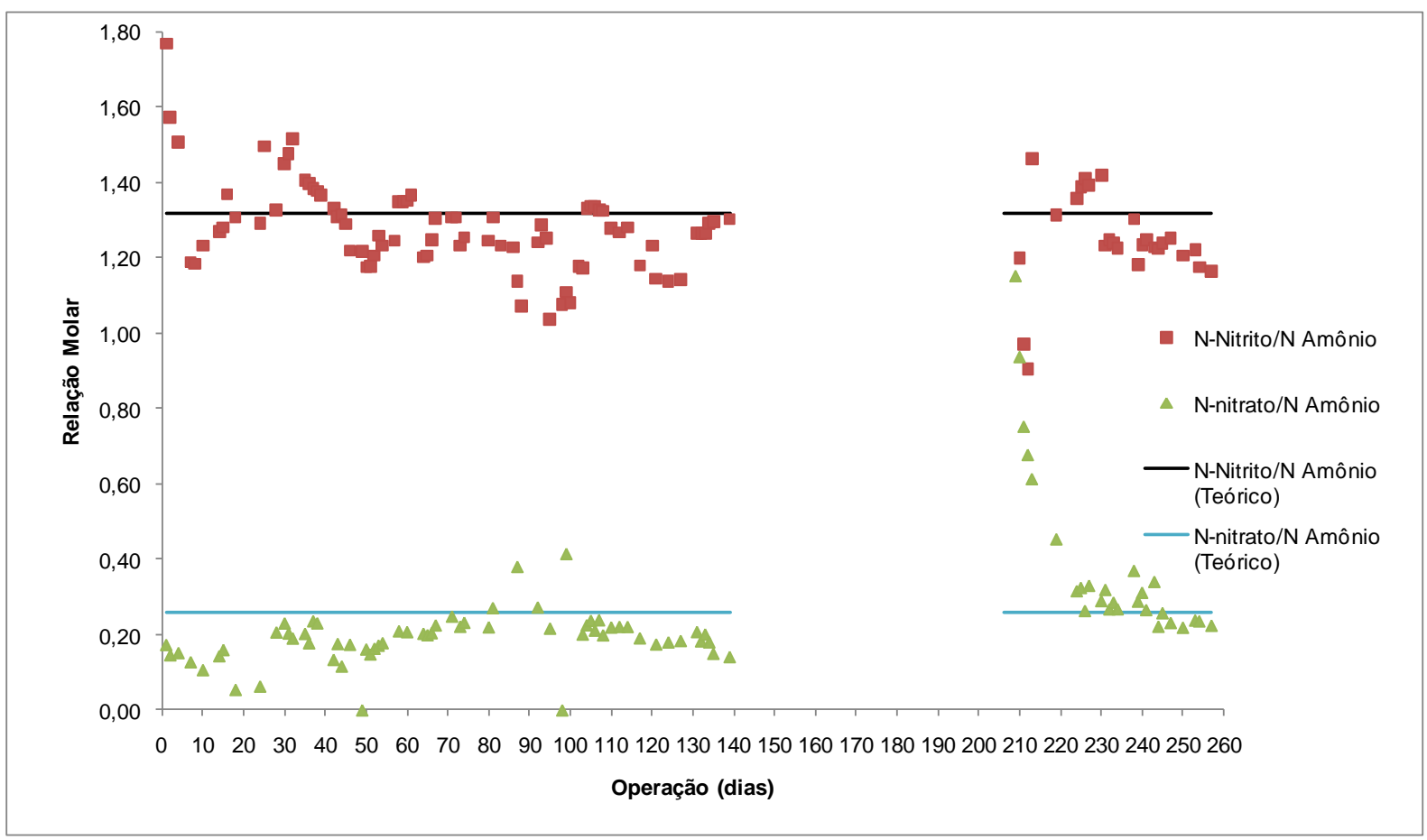

Figura 53. Relação estequiométrica de nitrito removido/amônio removido e nitrato produzido/amônio removido durante as etapas 1 a 6 do RLF

Os principais parâmetros de operação do RLF durante todas as etapas estão resumidos na

Tabela 15. A eficiência de conversão elevou de $92,1 \pm 5,9 \%$ na Etapa 1 para 97,3 \pm 1,1\% na Etapa 6, enquanto a eficiência de remoção manteve-se praticamente estável, 87,9 $\pm 6,8 \%$ na etapa 1 e $85,7 \pm 2,7 \%$ na Etapa 6 .

Vale à pena ressaltar que nas Etapas 2 e 4 (antes do reator ser submetido à aeração) a eficiência de remoção foi em torno de $89,5 \%$, muito próximo ao valor encontrado nas etapas 7 e 8 do RBS (90,2\%). Portanto, a eficiência no final da Etapa 6 foi ligeiramente 
reduzida em relação à Etapa 4 em virtude da condição anammox ter sido restabelecida há 57 dias, ante aos 139 dias de operação até o fim da Etapa 4.

$\mathrm{Na}$ etapa 3 devido aos problemas apresentados com a precipitação do meio afluente e vazão de $\mathrm{Ar} / \mathrm{CO}_{2}$, as eficiências foram menores e desvio padrão elevado, 87,4 $\pm 17,2 \%$ de eficiência de conversão e $81,8 \pm 16,8 \%$ de eficiência de remoção.

Tabela 15. Valores de carga nitrogenada, eficiência de remoção e conversão e relação estequiométrica do RLF

\begin{tabular}{ccccccc}
\hline Etapa & $\begin{array}{c}\text { Carga } \\
\text { nitrogenada } \\
\text { aplicada } \\
\left(\mathrm{g} \mathrm{N} / \mathrm{m}^{3}\right. \\
\text { dia })\end{array}$ & $\begin{array}{c}\text { Carga } \\
\text { nitrogenada } \\
\text { removida } \\
\left(\mathrm{g} \mathrm{N} / \mathrm{m}^{3}\right. \\
\text { dia })\end{array}$ & $\begin{array}{c}\text { Eficiência } \\
\text { de } \\
\text { conversão } \\
(\%)\end{array}$ & $\begin{array}{c}\text { Eficiência } \\
\text { de } \\
\text { remoção } \\
(\%)\end{array}$ & $\begin{array}{c}\text { N-Nitrito/ } \\
\text { N Amônio }\end{array}$ & $\begin{array}{c}\text { N-nitrato/ } \\
\text { N Amônio }\end{array}$ \\
\hline 1 & $154,8 \pm 2,23$ & $136,0 \pm 10,4$ & $92,1 \pm 5,9$ & $87,9 \pm 6,8$ & $1,37 \pm 0,20$ & $0,14 \pm 0,02$ \\
2 & $325,2 \pm 4,49$ & $291,1 \pm 16,7$ & $95,1 \pm 5,5$ & $89,5 \pm 5,1$ & $1,33 \pm 0,10$ & $0,16 \pm 0,07$ \\
3 & $461,4 \pm 8,62$ & $378,1 \pm 78,3$ & $87,4 \pm 17,2$ & $81,8 \pm 16,8$ & $1,23 \pm 0,09$ & $0,22 \pm 0,08$ \\
4 & $668,0 \pm 12,8$ & $598,5 \pm 22,5$ & $97,6 \pm 0,7$ & $89,5 \pm 2,2$ & $1,26 \pm 0,07$ & $0,20 \pm 0,03$ \\
Nitrificação/ & & & & & Não & Não \\
anammox & $111,2 \pm 6,6$ & $22,7 \pm 15,8$ & $60,8 \pm 19,0$ & $19,2 \pm 12,2$ & aplicável & aplicável \\
5 & $222,7 \pm 4,7$ & $187,6 \pm 6,4$ & $98,1 \pm 1,3$ & $85,0 \pm 3,2$ & $1,32 \pm 0,08$ & $0,31 \pm 0,06$ \\
6 & $409,2 \pm 1,7$ & $350,7 \pm 12,2$ & $97,3 \pm 1,1$ & $85,7 \pm 2,7$ & $1,22 \pm 0,04$ & $0,27 \pm 0,05$ \\
\hline
\end{tabular}

STROUS et al. (1997b) operaram, durante 115 dias, reator de leito fixo inoculado com biomassa anammox. Os autores obtiveram $88 \%$ e $99 \%$ de remoção de amônio e nitrito, respectivamente, para carga nitrogenada aplicada de $1680 \mathrm{~g} \mathrm{~N} / \mathrm{m}^{3}$ dia, e carga nitrogenada removida de $1100 \mathrm{~g} \mathrm{~N} / \mathrm{m}^{3}$ reator dia.

TSUSHIMA et al. (2007) obtiveram $26.000 \mathrm{~g} / \mathrm{m}^{3}$ dia de carga nitrogenada removida em reator de leito fixo. No entanto, a CNA foi de $58.500 \mathrm{~g} / \mathrm{m}^{3}$ dia, ou seja o reator apresentou eficiência abaixo de 50\%. Os autores mencionaram que esta carga nitrogenada foi aplicada somente um dia e, depois, a carga nitrogenada removida foi de $5.800 \mathrm{~g} / \mathrm{m}^{3}$ dia com eficiência de remoção em torno de $60 \%$.

A carga nitrogenada removida no RLF na etapa 4 (139 dias) foi $668 \mathrm{~g} \mathrm{~N} / \mathrm{m}^{3} \mathrm{dia}$. No entanto, o perfil espacial realizado revelou que praticamente todo nitrito foi removido no primeiro ponto de amostragem $(\mathrm{C} / \mathrm{D}=1)$. Portanto, o $\mathrm{RLF}$ foi operado abaixo de sua capacidade máxima de remoção.

O retorno da atividade anammox, após 55 dias de aeração, foi o dado mais importante da operação deste reator, uma vez que o estabelecimento do biofilme 
nitrificante-anammox foi possível, mas a eficiência de remoção de nitrogênio (19,2\%), nas condições em que este reator foi operado, foi abaixo do esperado. O processo de desnitrificação aeróbia poderia ser responsável pela remoção deste nitrogênio, mas devido à ausência de matéria orgânica no reator este processo foi descartado. Portanto, a segunda parte da hipótese foi corroborada nas condições apresentadas e testadas neste Reator de Leito Fixo, porém não de maneira satisfatória. 


\subsection{ANÁLISES MICROSCÓPICAS E DE BIOLOGIA MOLECULAR}

\subsubsection{Análises Microscópicas}

O inóculo proveniente do reator nitrificante-desnitrificante da indústria produtora de aminoácido apresentou biomassa com diversas morfologias (Figura 54). As morfologias apresentadas na Figura 54 foram semelhantes a: (a) Zooglea sp.; (b) filamento semelhante à Beggiatoa sp.; (c) bacilos, cocos, cocobacilos e filamentos; (d) bacilos e cocos em suspensão; (e) aglomerado de bacilos e cocos; diatomácea; (f) aglomerado de bacilos e cocos, estreptococos e rizópodo semelhante à Arcella sp (JENKINS et al., 2003). 


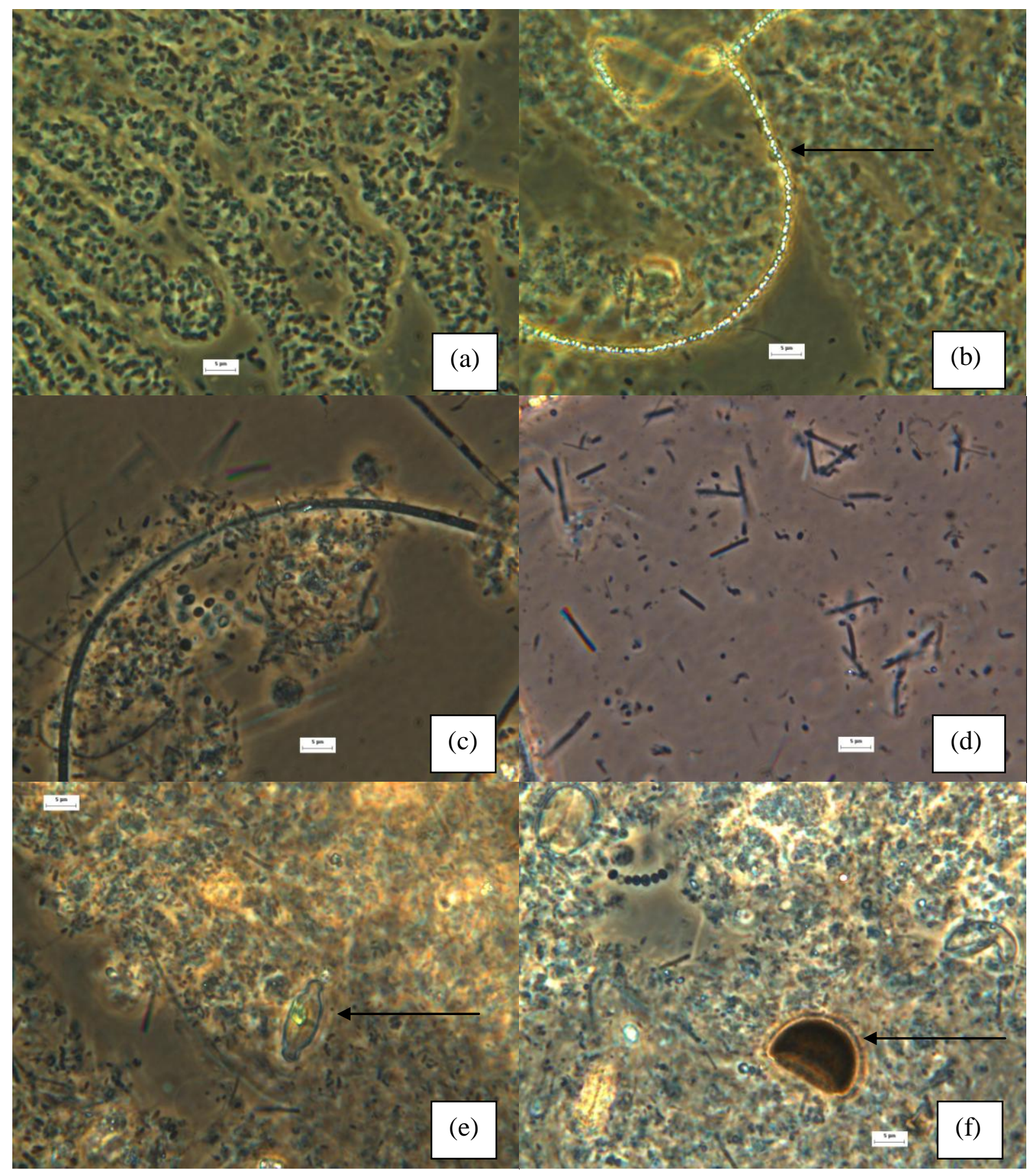

Figura 54. Microscopia de contraste de fase do inóculo utilizado no RBS: (a) Zooglea sp., (b) filamento semelhante à Beggiatoa sp. (seta); (c) bacilos, cocos, cocobacilos e filamentos; (d) bacilos e cocos em suspensão; (e) aglomerado de bacilos e cocos; diatomácea (seta); (f) aglomerado de bacilos e cocos, estreptococos e rizópodo semelhante à Arcella sp (seta)

Com 67 dias de operação, sob condições anammox (autotróficas) a biomassa já se apresentava menos diversificada (Figura 55), apresentando cocos de aproximadamente 2 $\mu \mathrm{m}$, aglomerados com cocos semelhantes à morfologia do grupo anammox, filamentos e cocobacilos. 


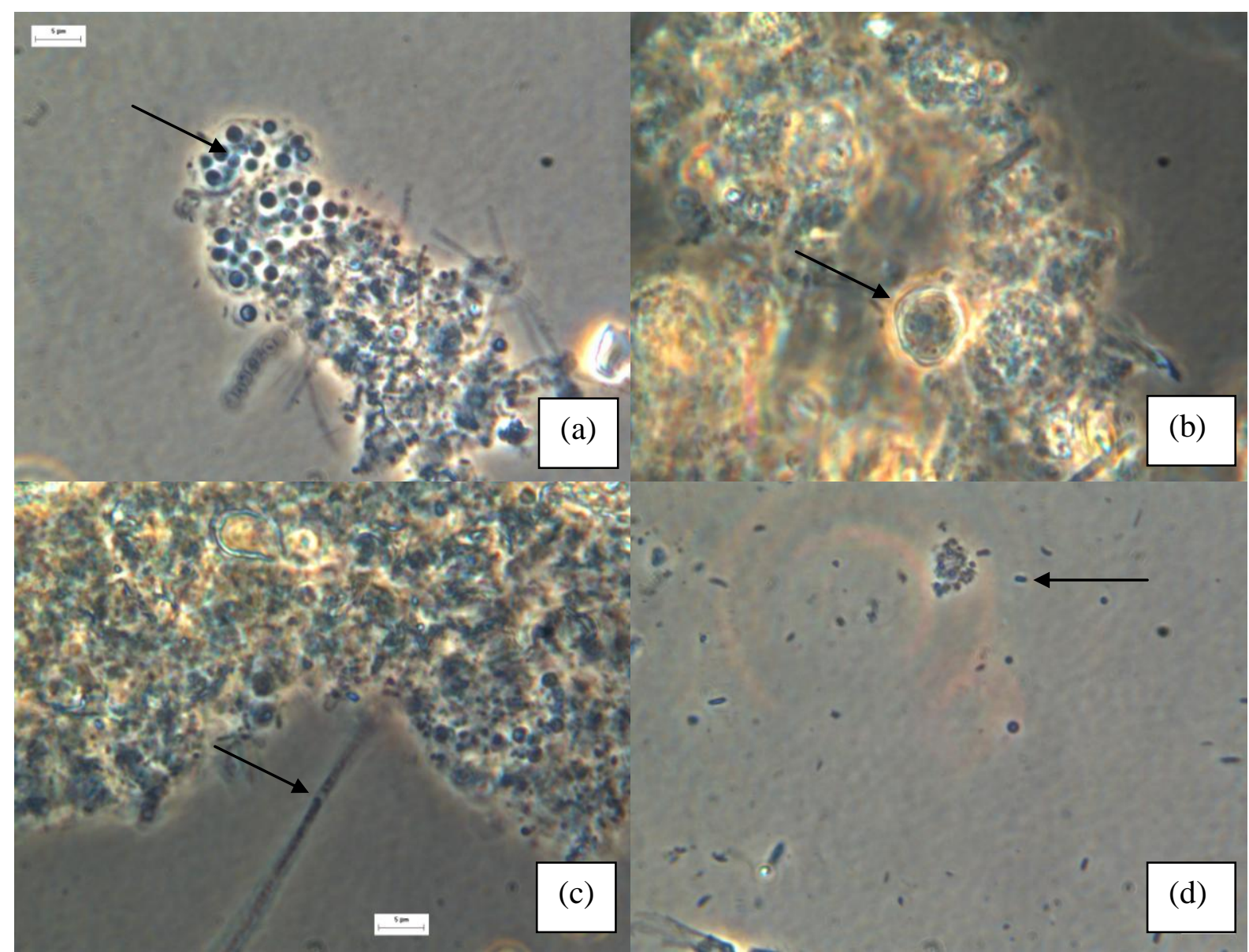

Figura 55. Microscopia de contraste de fase da biomassa presente no RBS com 67 dias de operação: (a) cocos, (b) aglomerado de cocos semelhante às bactérias anammox, (c) filamento, (d) bacilos e cocos

De modo geral pode-se dizer que a biomassa apresentou tendência para se aglutinar em torno de filamentos, para posteriormente formar os grânulos conforme pode ser visto na Figura 56. 


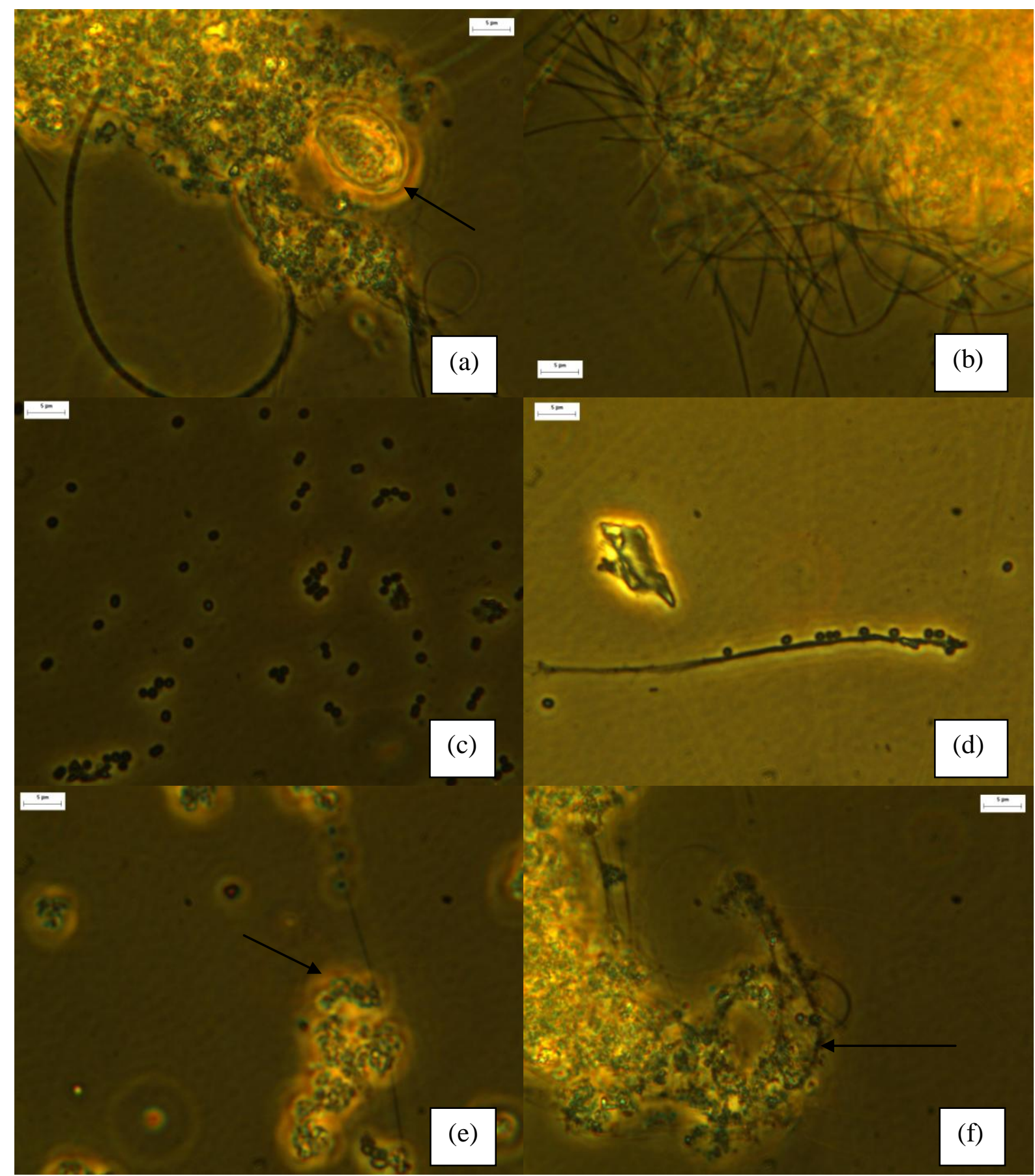

Figura 56. Microscopia de contraste de fase da biomassa presente no RBS com 344 dias de operação: (a) filamentos e aglomerado de cocos semelhante às bactérias anammox , (b) aglomerado de filamentos, (c) cocos, (d) cocos e filamento, (e) aglomerado de cocos semelhante às bactérias anammox aderidos a filamentos e (f) cocos aderidos a filamentos

Ao final da etapa 4 de operação do RLF (antes da operação nitrificante/anammox) foi realizada análise da biomassa aderida ao meio suporte e suspensa no reator. A Figura 57 revela morfologias semelhantes aos aglomerados anammox, poucos filamentos e cocos. 


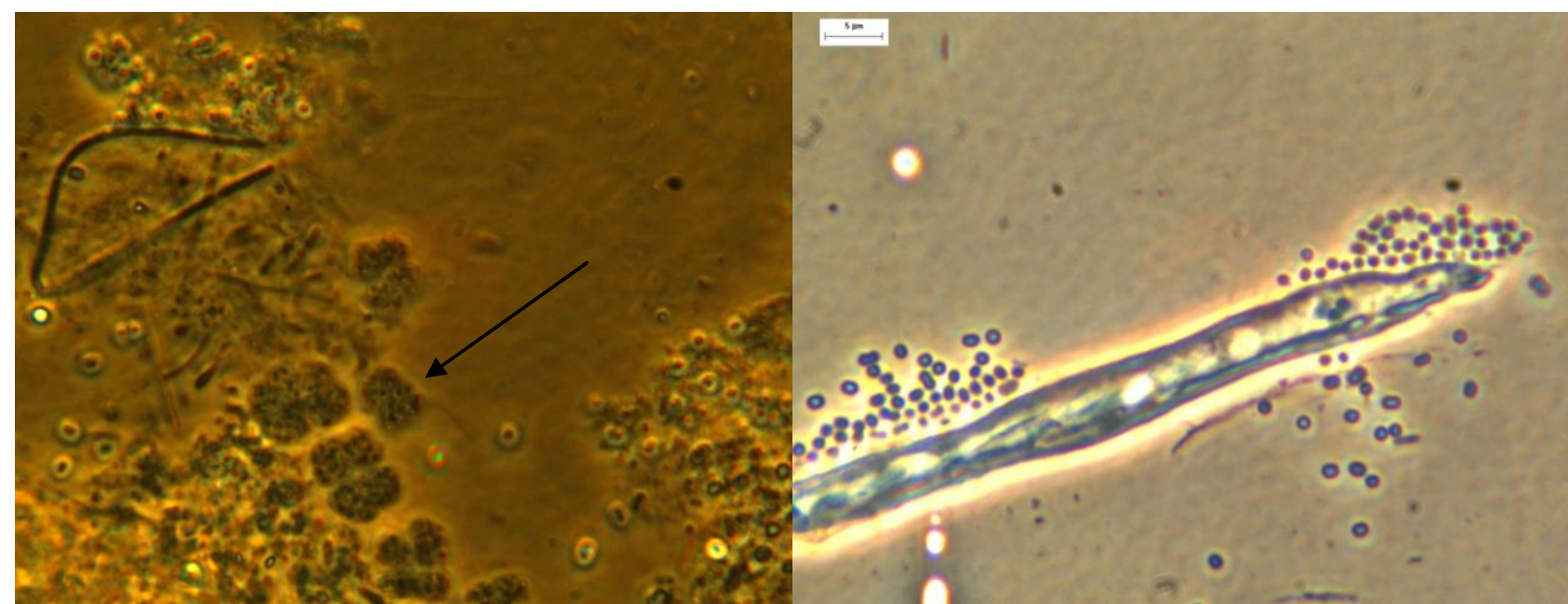

Figura 57. Microscopia de contraste de fase da biomassa presente no RLF com 139 dias de operação; (a) morfologias semelhantes às bactérias anammox, (b) cocos

\subsubsection{Análises de Biologia Molecular}

\subsubsection{Caracterização Filogenética da Biomassa Presente no RBS com 170 dias de operação}

Após 170 dias de operação do RBS foi retirada amostra da biomassa para extração de DNA e realizada reação em cadeia da polimerase (PCR) utilizando-se primers específicos de aproximadamente 780 pares de bases (PLA 46Frc-AMX820R) (SCHMID et al., 2000; EGLI et al., 2003).

Análise das seqüências do gene RNAr 16S utilizando primers específicos mostrou que 21 clones produziram cinco Unidades Taxonômicas Operacionais (UTOs) com 1\% de dissimilaridade obtido pela utilização do programa DOTUR (SCHLOSS \& HANDELSMAN, 2005) (Tabela 16).

$\mathrm{Na}$ Figura 58 encontram-se delineadas as curvas de rarefação obtidas para as amostras sequenciadas utilizando-se os primers específicos para anammox. Para 99\% de similaridade foram obtidas cinco UTOs e, com 90\%, somente duas UTOs.

Para se ter maior varredura da biblioteca do gene RNAr $16 \mathrm{~S}$ da amostra do $170^{\circ}$ dia de operação do RBS precisaria ser adotado índice de similaridade de $90 \%$, pois, como pode ser observado, com o aumento de amostras sequenciadas não há aumento de UTOs (Figura 58). No entanto, o intuito da análise com primers específicos foi verificar a presença de bactérias anammox, após 170 dias operação, sob condições anammox. Desse modo, foi adotado índice de $99 \%$ de similaridade entre as sequências para se observar maior diversidade entre as amostras (Figura 58). 
Tabela 16. Número de clones presentes em cada UTO (com similaridade mínima de 99\%) utilizando primers específicos para anammox

\begin{tabular}{cc}
\hline UTO & Número de Clones \\
\hline 1 & 11 \\
2 & 7 \\
3 & 1 \\
4 & 1 \\
5 & 1 \\
\hline TOTAL & 21 Clones
\end{tabular}

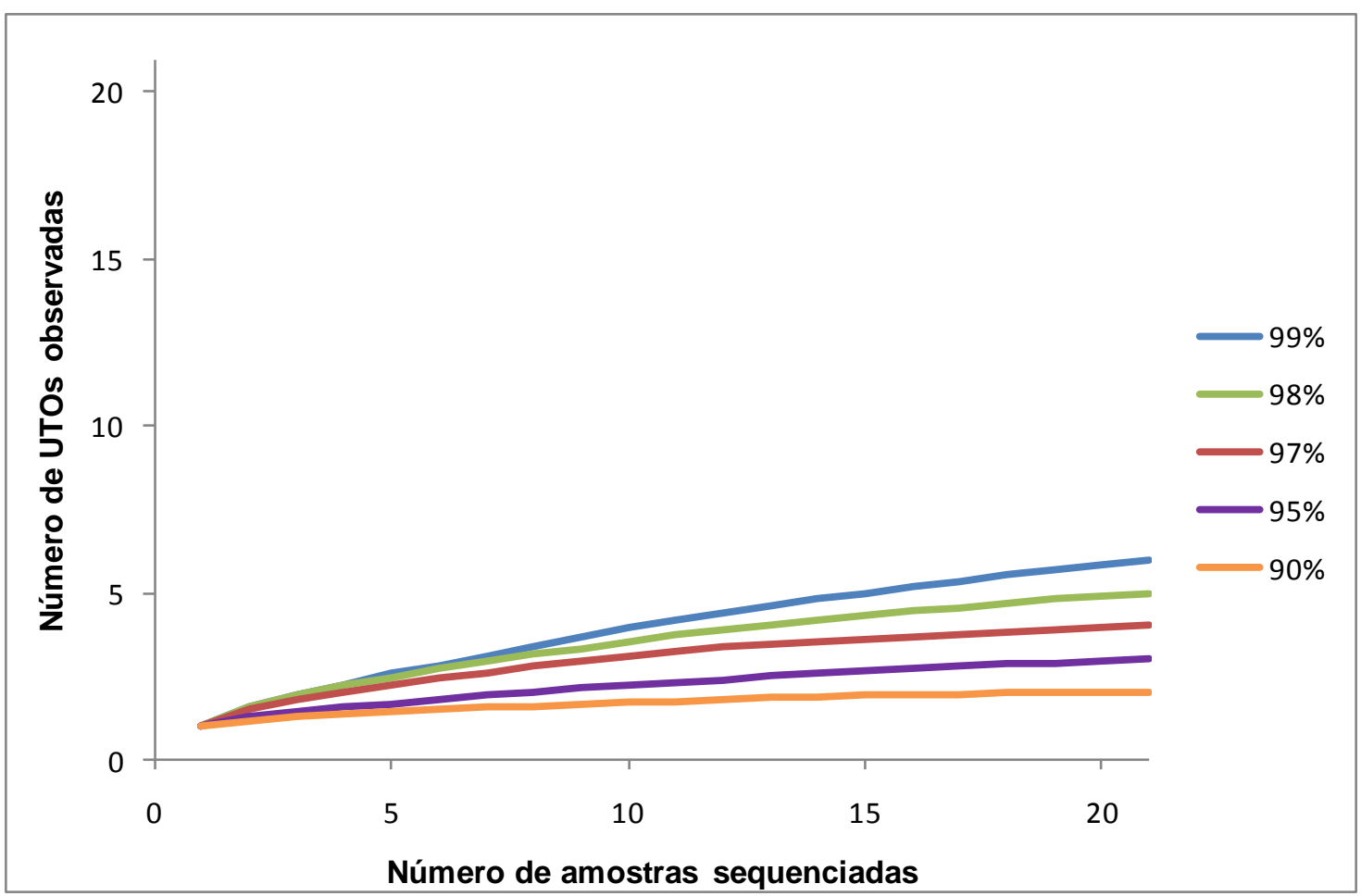

Figura 58. Curvas de rarefação de amostras do RBS sequenciadas utilizando primers específicos a partir de análise utilizando DOTUR

A proporção entre os clones sequenciados está representada pela Figura 60. A identidade entre as UTOs 1, 2 e 4 (19 sequências) e Brocadia anammoxidans foram de 92, 97 e 96\%, respectivamente, ainda pode ser observado que as UTOs 2 e 4 estão muito próximas filogeneticamente (Figura 59). As UTOs 3 e 5 tiveram 99\% de similaridade com Anamoxoglobus propionicus (Figura 59). A árvore filogenética baseada das cinco UTOs comparadas com bactérias anammox (ordem Brocadiales) está apresentada na Figura 58.

Em experimentos em batelada, com Brocadia anammoxidans foi verificada inibição irreversível, quando nitrito e fosfato, em concentrações acima de $70 \mathrm{mg} / \mathrm{L}$ e $60 \mathrm{mg} / \mathrm{L}$, respectivamente foram adicionados separadamente nos sistemas (VAN DE 
GRAAF et al., 1996; STROUS et al., 1997a; STROUS et al., 1997b). As duas linhagens cresceram adequadamente a $37^{\circ} \mathrm{Ce} \mathrm{pH} 8$.

KARTAL et al. (2007b) descreveram nova espécie de bactéria anammox, presente em reator em batelada seqüencial, com metabolismo diferente das anteriormente descritas. Essa nova espécie foi capaz de co-oxidar amônio e ácido propiônico, e foi, provisoriamente, denominada Anammoxoglobus propionicus. Essa nova espécie apresentou velocidade específica de remoção de ácido propiônico de $0,64 \mu \mathrm{mol} / \mathrm{g}$ proteína.min. Os autores realizaram experimento em batelada inoculado com $60 \%$ da cultura purificada de B. anammoxidans e $40 \%$ da cultura enriquecida de A. propionicus em meio com nitrito (1260mgN-NO $\left.{ }_{2}{ }^{-} / \mathrm{dia}\right)$, amônio (1260mgN-NH$\left.{ }_{4}{ }^{+} / \mathrm{dia}\right)$ e $1,095 \mathrm{mg}$ propionato/dia. Após quatro meses de operação a população da espécie heterotrófica (Anammoxoglobus propionicus) apresentou $80 \%$ do total de células detectadas por análises de FISH.

A presença de $A$. propionicus no RBS com 170 dias de operação pode ser devido a ácido propiônico oriundo da morte celular e endogenia de porção da biomassa presente no lodo não adaptada às condições impostas no RBS.

Segundo o levantamento bibliográfico feito até o presente momento, não se conhece biomassa anammox, presente em reatores para tratamento de águas residuárias, onde estejam presentes mais de uma espécie de bactéria anammox. Portanto, este trabalho encontrou, pela primeira vez, duas espécies num mesmo consórcio microbiano após 170 dias de enriquecimento. 


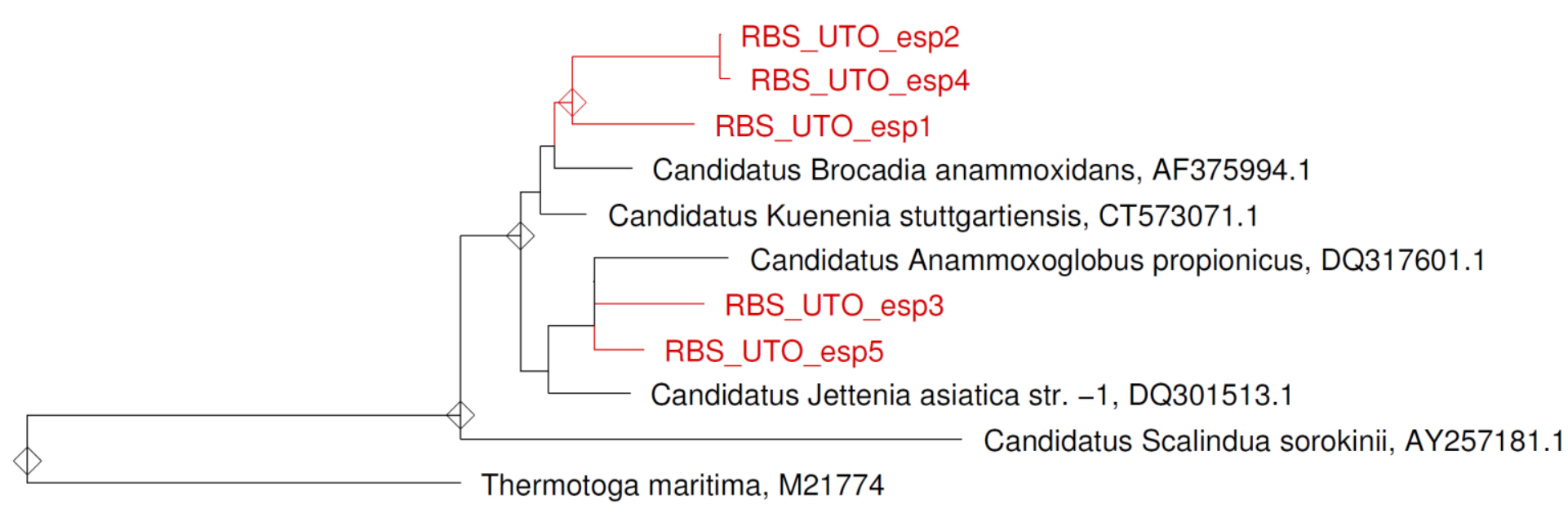

010

Figura 59. Árvore filogenética baseada em fragmento do gene rRNA 16S das cinco UTOs comparadas com bactérias anammox (ordem Brocadiales). Thermotoga maritima foi utilizada como grupo-externo, a barra indica dez substituições de 100 nucleotídeos. Árvore construída pelo programa ARB com filtro LanemaskPH 
As cinco UTOs foram relacionadas a duas espécies somente, Brocadia anammoxidans e Anammoxoglus propionicus a (Figura 60). Portanto, pode-se afirmar que com 170 dias de operação do RBS com nível de similaridade de 99\% entre as sequências amostradas, $90,5 \%$ das bactérias anammox presentes no RBS foram similares à $B$. anammoxidans e 9,5\% das bactérias foram similares à A. propionicus.

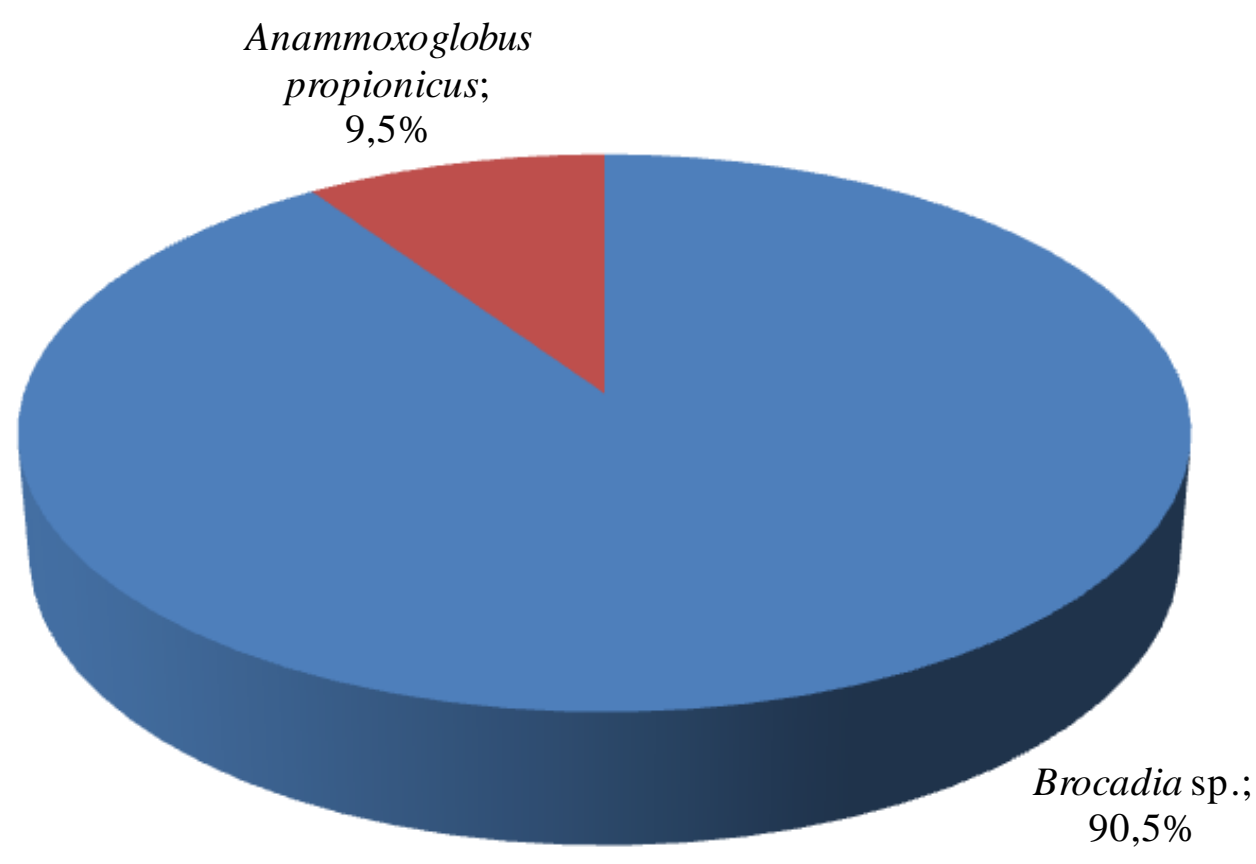

Figura 60. Constituição das sequências (utilizando primers específicos) amostradas com 170 dias de operação do RBS

\subsubsection{Caracterização Filogenética da Biomassa Presente no RBS com 450 dias de operação}

Após 450 dias de operação do RBS foi retirada amostra de DNA e realizada reação em cadeia da polimerase (PCR) utilizando-se primers universais de aproximadamente 1.500 pares de bases $6 \mathrm{~F}-1510 \mathrm{R}$ (EGLI et al., 2003).

Análise dos fragmentos de aproximadamente $600 \mathrm{pb}$ do gene RNAr $16 \mathrm{~S}$ revelou que 48 clones produziram 19 UTOs em nível de $97 \%$ de similaridade utilizando programa DOTUR (SCHLOSS \& HANDELSMAN, 2005) (Tabela 17).

Na Figura 61 estão apresentadas as curvas de rarefação das amostras sequenciadas utilizando-se os primers universais para Bacteria. Entre 95 e $99 \%$ de similaridade, entre as sequências analisadas, uma UTO é adicionada a cada ponto percentual. 
Pode-se observar pela Figura 61 que não foi possível a varredura completa da amostra de DNA obtida com 450 dias de operação do RBS, com 97\% e $92 \%$ de similaridade. No entanto, foi adotado índice de $97 \%$ de similaridade entre UTOs pela aceitável cobertura da amostra.

A Figura 62 apresenta a árvore filogenética das UTOs encontradas no RBS com 450 dias de operação. As UTOs foram distribuídas em seis grandes grupos de Bacteria: Planctomycetes, beta-Proteobacteria, bactérias verdes sulfurosas do filo Chlorobi, filo Nitrospira, filo Chloroflexi e filo OP 11.

A composição encontrada por STROUS et al. (1999a) indica aproximadamente 1\% da biomassa enriquecida como sendo alfa, gama e delta-Proteobacteria, Gram positivas e Cytophaga; $10 \%$ de bactérias filamentosas e $80 \%$ de Planctomycetes.

No estudo metagenômico conduzido por STROUS et al. (2006) foram encontrados os seguintes grupos: alfa, beta, gama e delta-Proteobacteria, Acidobacteria, Chloroflexi, Chlorobi, Bacteroidetes, Plactomycetes e filo candidato OP 11. A proporção entre os grupos dentro da comunidade microbiana não foi relatada pelos autores.

Tabela 17. Número de clones presentes em cada UTO (com similaridade mínima de 97\%) encontrada no sequenciamento da amostra do RBS utilizando primers universais para Bacteria

\begin{tabular}{cc}
\hline UTO & Número de Clones \\
\hline 1 & 1 \\
2 & 3 \\
3 & 1 \\
4 & 1 \\
5 & 1 \\
6 & 1 \\
7 & 4 \\
8 & 4 \\
9 & 5 \\
10 & 4 \\
11 & 2 \\
12 & 1 \\
13 & 1 \\
14 & 4 \\
15 & 5 \\
16 & 3 \\
17 & 1 \\
18 & 1 \\
19 & 5 \\
\hline TOTAL & 48 Clones \\
\hline
\end{tabular}




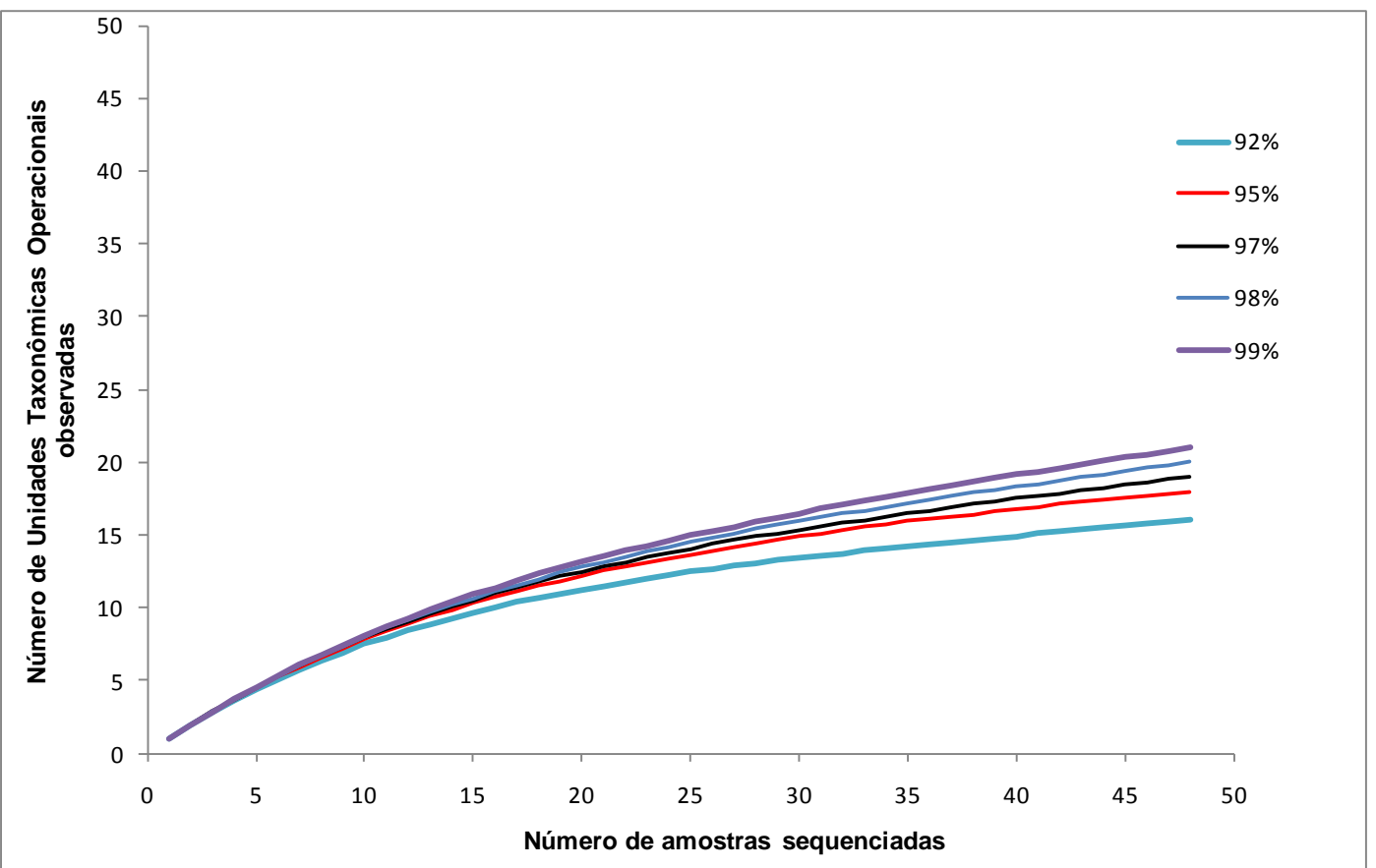

Figura 61. Curvas de rarefação de amostra do RBS sequenciadas utilizando primers universais a partir de análise utilizando DOTUR 


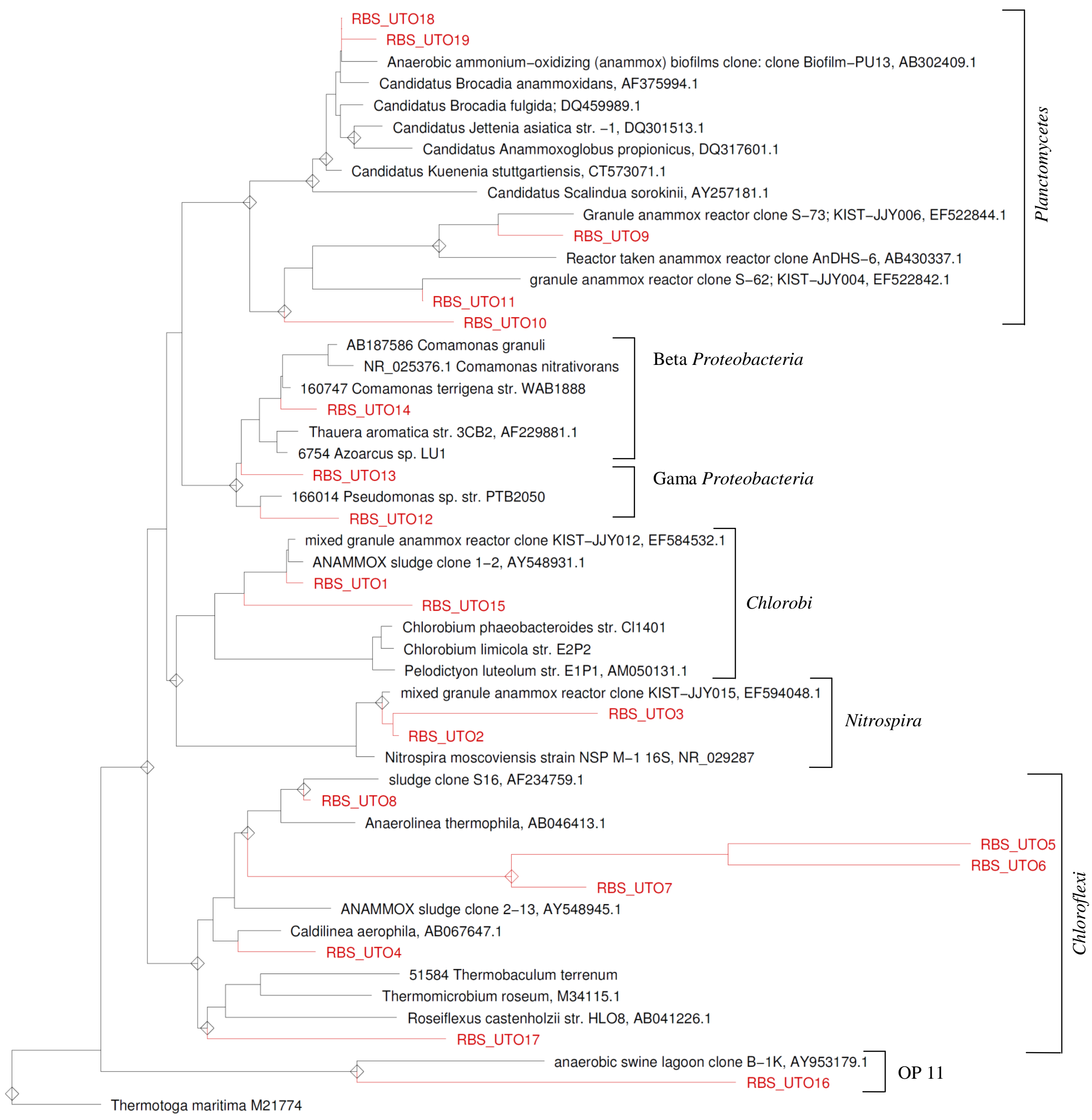

Figura 62. Árvore filogenética baseada em fragmento do gene RNAr 16S das 19 UTOs a partir de sequências encontradas nas amostras do RBS Thermotoga maritima foi utilizada como grupo-externo, a barra indica dez substituições de em 100 nucleotídeos. Árvore construída pelo programa ARB com filtro LanemaskPH 
A Tabela 18 mostra as relações filogenéticas entre as UTOs e espécies mais próximas (Figura 62).

Tabela 18. Relação filogenéticadas UTOs obtidas do sequenciamento da amostra com 450 dias de operação do RBS

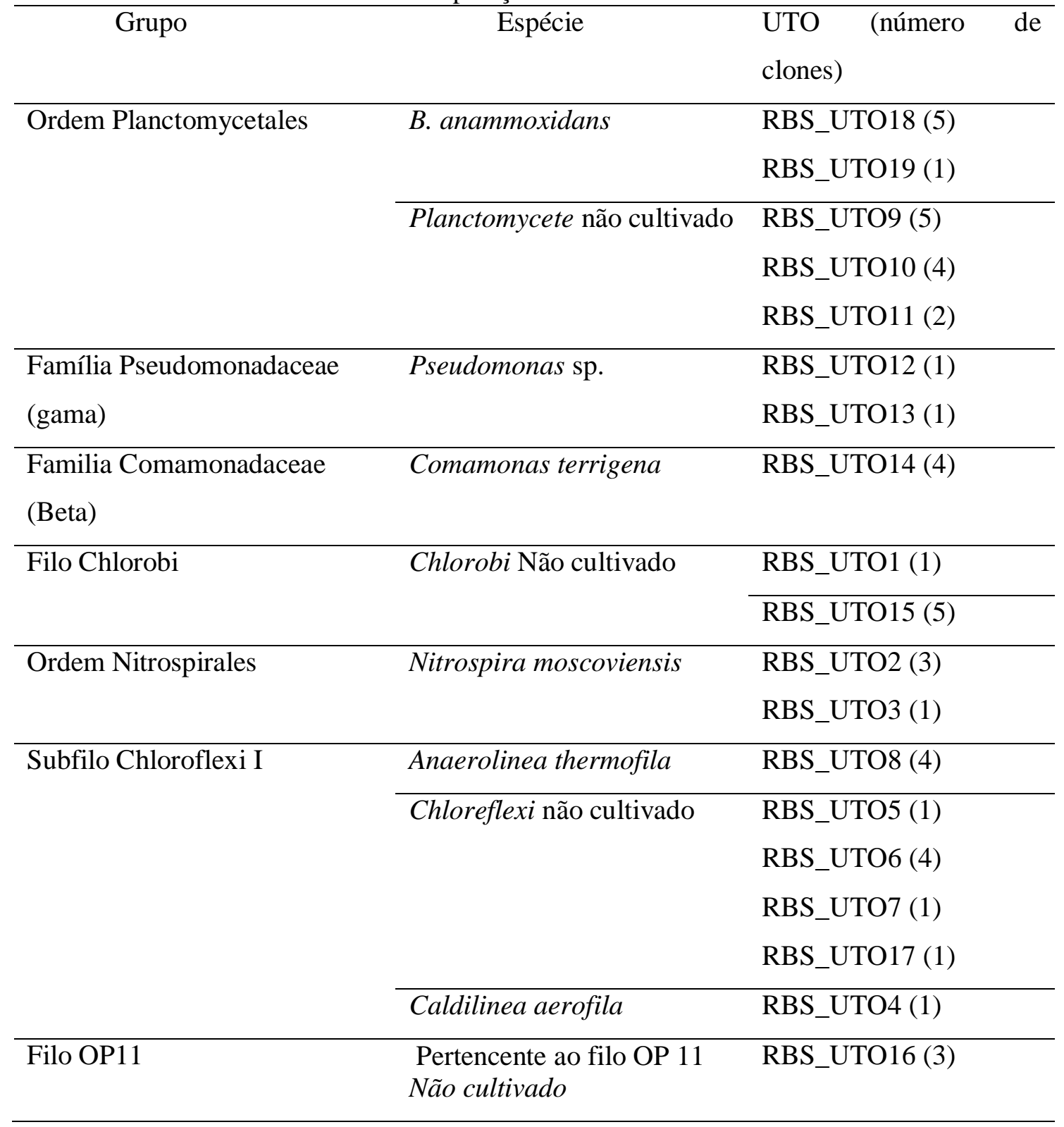

A Figura 63 mostra a proporção dos grupos bacterianos presente no RBS com 450 dias de operação. Pode se observar que 35,4\% das populações presente no reator pertenciam ao grupo das bactérias anammox (filo Planctomycete). Curiosamente, após 450 dias de operação, Brocadia anamoxidans foi selecionada positivamente em detrimento à Anammoxuglobus propionicus. 
Na maioria das estações de tratamento analisadas Kuenenia stuttgartiensis e não Brocadia anamoxidans foi a espécie anammox mais abundante (JETTEN et al., 2001).

A presença de clones relacionados à Pseudomonas sp. e Comamonas terrigena corroboram a ocorrência da desnitrificação no RBS, além da possível desnitrificação pelas bactérias anammox.

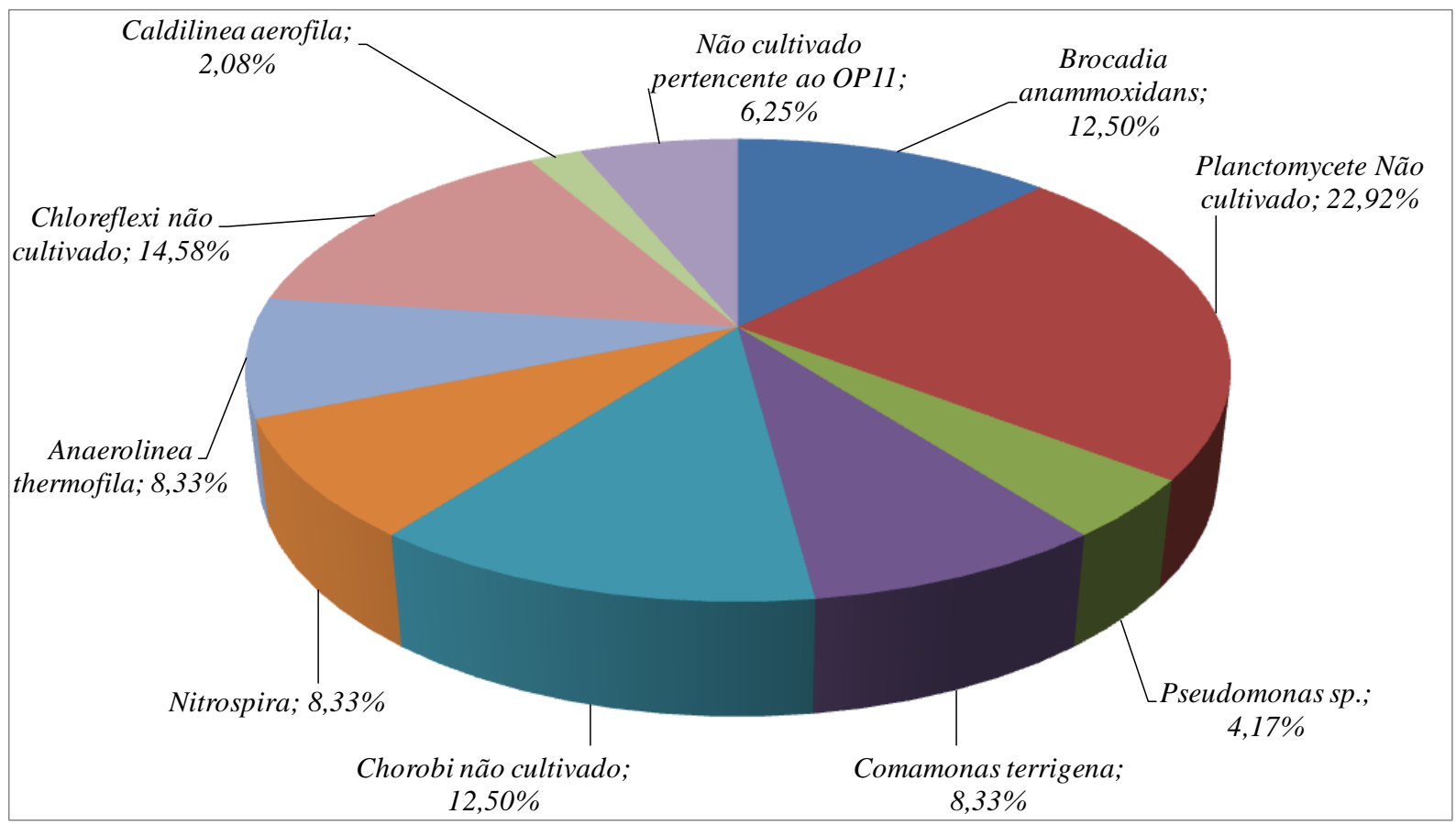

Figura 63. Constituição da comunidade microbiana presente no RBS com 450 dias de operação.

Microrganismo mais próximo filogeneticamente; porcentagem em relação à comunidade

O estudo metagenômico realizado por STROUS et al. (2006) mostrou presença de microrganismos não cultivados do grupo Chlorobi, além de K. stuttgartiensis.

As bactérias verdes sulforosas (Filo Chlorobi) são comumente encontradas em ambientes aquáticos com luz e anóxicos, além de sedimentos e outros ambientes ricos em sulfetos, incluindo fontes de água quente. Por causa de adaptações originais em seu fotossistema, essas bactérias são capazes de crescimento na intensidade de luz sob, na qual outros fototróficos não podem sobreviver (MANSKE et al., 2005).

Todas as linhagens de bactérias verdes sulforosas são estritamente anaeróbias e obrigatoriamente fotoautotróficas. Dentre as espécies descritas, nenhuma delas é capaz de realizar metabolismo respiratório ou fermentar. A maioria dessas bactérias usa elétrons derivados de compostos reduzidos de enxofre em combinação com a energia da luz para reduzir o carbono e nitrogênio (FRIGAARD et al., 2003). 
Na presença de sulfeto e bicarbonato, substratos orgânicos simples são assimilados (IMHOFF, 2003). O reator não foi mantido no escuro estrito, então baixa luminosidade pode ter sido suficiente para sobrevivência desses microrganismos relacionados ao filo Chlorobi no reator em conjunto com as condições explicitadas acima.

O gênero Nitrospira engloba espécies marinhas, todavia, Nitrospira marina e Nitrospira moscoviensis, foram isoladas de sistema de aquecimento de água municipal. Nitrospira constitui um agrupamento monofilético com os gêneros Thermodesulfovibrio, Leptospirillum e Magnetobacterium. Este grupo filogenético tem sido identificado recentemente como um novo filo do domínio Bacteria e foi nomeado filo Nitrospira (EHRICH et al., 1995)

Há acúmulo de evidências moleculares que BNO relacionados à Nitrospira são de elevada importância para a oxidação de nitrito em estações de tratamento de efluentes (DAIMS et al., 2000). Assim como Nitrospina gracilis, os membros do gênero Nitrospira não possuem membranas intracitoplasmáticas.

Recentemente, DAIMS e colaboradores (DAIMS et al., 2000; DAIMS et al., 2001) mostraram que, em lodos ativados nitrificantes, Nitrospira não cultivadas foram capazes de fixar $\mathrm{CO}_{2} \mathrm{e}$, simultaneamente, formar piruvato, mas não acetato, butirato e propionato. Portanto, esse metabolismo indica a possibilidade da existência de ácidos orgânicos de cadeia curta pelo metabolismo autotrófico de Nitrospira dentro do reator.

Anaerolinea thermophila são bactérias filamentosas com mais de $100 \mu \mathrm{m}$ comprimento e $0,2 \mu \mathrm{m}$ de espessura. A faixa de $\mathrm{pH}$ para o crescimento é 6 a 8 . O tempo de geração é de 3 dias sob condições ótimas de crescimento. Na presença de extrato de levedura, o crescimento e utilização do substrato pode ser observado com glicose, frutose, manose, galactose, rafinose, sacarose e amido. Os substratos que se seguem não são utilizados, mesmo na presença de extrato de levedura: crotonato, $\mathrm{H}_{2} / \mathrm{CO}_{2}$ mais acetato, lactato, glicerol, acetato, propionato, butirato, malato, succinato, etanol, metanol, 1propanol, benzoato, hidroquinona, fenol e formiato mais acetato. Nenhum dos seguintes compostos são utilizados como o receptor elétron: sulfato, nitrato, sulfito, tiossulfato (SEKIGUCHI et al., 2003).

Caldilinea aerophila são células em formato filamentoso com mais de $100 \mu \mathrm{m}$ por 0,7-0,8 $\mu \mathrm{m}$ de espessura. $\mathrm{O}$ crescimento ocorre entre 37 e $65^{\circ} \mathrm{C}$. A faixa de $\mathrm{pH}$ para o crescimento é 7 a 9; crescimento ótimo em pH 7,5 e 8,5. O tempo de geração é de 5 h sob condições ótimas de crescimento. Utiliza extrato de levedura como o melhor substrato para 
crescimento em condições aeróbias e anaeróbias. Na presença de extrato de levedura utilizados seguintes substratos: glicose, triptona, sacarose, maltose, rafinose, amido, glicerol, acetato, piruvato, lactato, succinato, fumarato e glutamato. Os substratos a seguir não são utilizados, mesmo na presença de extrato de levedura: manose, frutose, arabinose, xilose, ribose, o etanol, o formato, malato, alanina, ácidos e serina casaminoácidos. O crescimento é observado em condições anaeróbias. Nenhuma destas substâncias é utilizada como receptor de elétrons em condições anóxicas: sulfato, nitrato, sulfito, tiossulfato (SEKIGUCHI et al., 2003).

Os filamentos visualizados pelas análises microscópicas tanto no RBS quanto no RLF foram relacionados às bactérias verdes não sulfurosas do filo Chloroflexi, Anaerolinea thermophila e Caldilinea aerophila. A manutenção desses filamentos no reator foi possível, provavelmente, devido a ácidos orgânicos de cadeia curto oriundos da decomposição da biomassa ou do metabolismo de Nitrospira; ou seja, a produção de ácidos orgânicos de cadeia curta pelo metabolismo autotrófico.

Organismos pertencentes ao filo (ou divisão) candidato OP11 foram detectadas apenas em amostras ambientais baseada em análises de seqüência RNAr. Estudos preliminares indicaram que esses são abundantes e amplamente distribuídos na natureza e muito diversos filogeneticamente (HUGENHOLTZ et al., 1998; HARRIS et al., 2004).

\subsubsection{Caracterização Filogenética da Biomassa presente no RLF com 139 dias de operação}

Após 139 dias de operação do RLF, sob condições anammox foi retirada amostra da biomassa para extração de DNA e realizada a reação em cadeia da polimerase (PCR) utilizando-se primers universais de aproximadamente 1.500 pares de bases $16 \mathrm{~S} 6 \mathrm{~F}-16 \mathrm{~S}$ 1510R (EGLI et al., 2003).

Análise dos fragmentos de aproximadamente 600 pb do gene RNAr 16S utilizando primers universais revelou que 25 clones produziram 11 UTOs com 97\% de similaridade utilizando o programa DOTUR (Tabela 19) .

A Figura 64 mostra as curvas de rarefação das amostras sequenciadas utilizando-se os primers universais para Bacteria. A cobertura da comunidade presente no RLF por meio de sequências obtidas por clonagem não foi tão efetiva como no caso do RBS O reduzido número de clones sequenciados não foi por falta de esforço experimental e laboratorial, pois foram sequenciados 100 clones após quatro tentativas de plaqueamento.Para a amostra 
do RBS com 450 dias foram sequenciados 150 clones,com rendimento de somente 48 sequências.

O motivo pelo qual ocorreu este reduzido rendimento das sequências ainda permanece desconhecido, mas pode ter sido em decorrência dos primers degenerados dificultando o correto anelamento na PCR, apesar da eletroforese em gel de agarose apresentar fragmento no tamanho desejado antes da reação de sequenciamento.

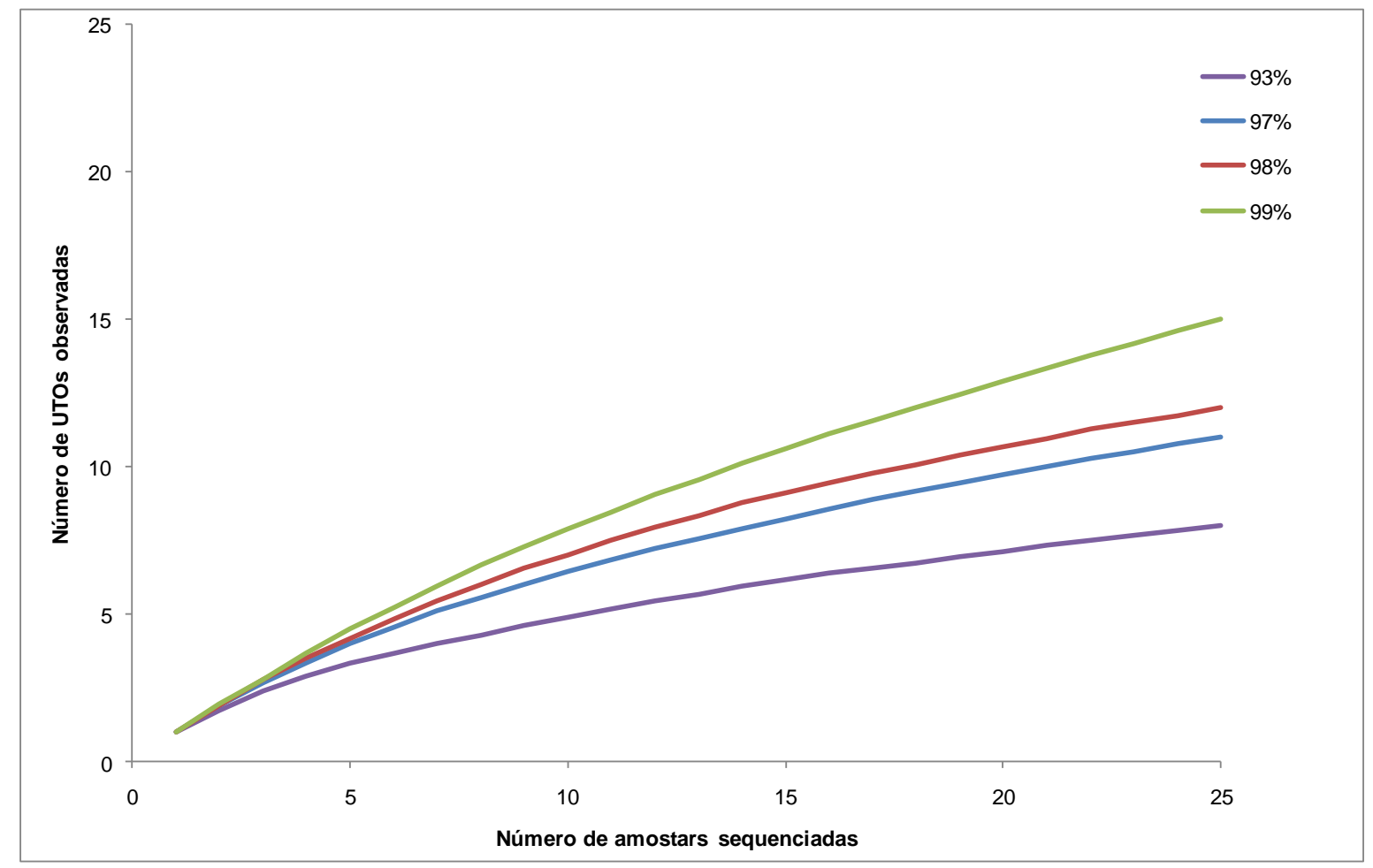

Figura 64. Curvas de rarefação de amostra do RLF sequenciadas utilizando primers universais a partir de análise utilizando DOTUR

Tabela 19. Número de clones presentes em cada UTO (com similaridade mínima de 97\%) encontrada no sequenciamento da amostra do RLF utilizando primers universais para Bacteria

\begin{tabular}{cc}
\hline UTO & Número de Clones \\
\hline 1 & 3 \\
2 & 7 \\
3 & 1 \\
4 & 1 \\
5 & 1 \\
6 & 1 \\
7 & 1 \\
8 & 2 \\
9 & 1 \\
10 & 2 \\
11 & 5 \\
\hline TOTAL & 25 Clones \\
\hline
\end{tabular}


A Figura 65 apresenta a árvore filogenética das UTOs obtidas da amostra do RLF com 139 dias de operação. As UTOs RLF_UTO3 e RLF_UTO4 foram relacionadas à $B$. anammoxidans, mas com elevada distância filogenética.

Pode se observar nitidamente que a condição de crescimento aderido em meio suporte no RLF selecionou microrganismos anammox, e clones relacionados ao filo OP 11 não apareceram nas amostras sequenciadas. Além disso, o número de clones relacionados ao filo Nitrospira aumentaram de 6,25 para 24\% (Figura 65 e Figura 66).

EGLI et al. (2003) avaliaram a composição do biofilme de reator de biodiscos rotativos, submetidos à $500 \mathrm{mg} \mathrm{N}-\mathrm{NH}_{4}{ }^{+}$, por meio de análise de hibridização in situ com sondas fluorescentes (FISH). Os autores verificaram que 7\% foram similares a filamentos do filo Cythophga, 30\% relacionados à Nitrosomonas europaea/eutropha, 30\% a bactérias anammox relacionadas à $K$. stuttgartiensis, $5 \%$ relacionados à Nitrospira sp. Em análise por biblioteca do gene RNAr $16 \mathrm{~S}$, os autores, não encontraram clones relacionados à bactérias anammox e nitrito oxidantes (BNO), apesar da boa representatividade por análise de FISH. Foram encontrados clones relacionados à Sphyngomonas sp., Staphylococcus sp., Nitrosomonas sp., Cythophaga sp. e aos filos OP 3 e OP11.

As relações filogenéticas entre as UTOs e a espécie mais próxima na árvore filogenética (Figura 65) estão resumidas na Tabela 20.

Tabela 20. Relação filogenética das UTOs obtidas do sequenciamento da amostra com 139 dias de operação do RLF

\begin{tabular}{lll}
\hline Grupo & Espécie & UTO (número de clones) \\
\hline Ordem Planctomycetales & B. anammoxidans & RLF_UTO1 (3) \\
& & RLF_UTO2 (7) \\
& & RLF_UTO3 (1) \\
& & RLF_UTO4 (1) \\
\cline { 2 - 3 } & Planctomycete não cultivada & RLF_UTO7 (1) \\
\hline Família Pseudomonadaceae & Pseudomonas sp. & RLF_UTO8 (2) \\
& & RLF_UTO9 (1) \\
\hline Filo Nitrospira & Nitrospira não cultivada & RLF_UTO11 (5) \\
& & RLF_UTO6 (1) \\
\hline Filo Chlorobi & Chlorobi não cultivada & RLF_UTO10 (2) \\
\hline Subfilo Chloroflexi I & Chloroflexi não cultivada & RLF_UTO5 (1) \\
\hline
\end{tabular}




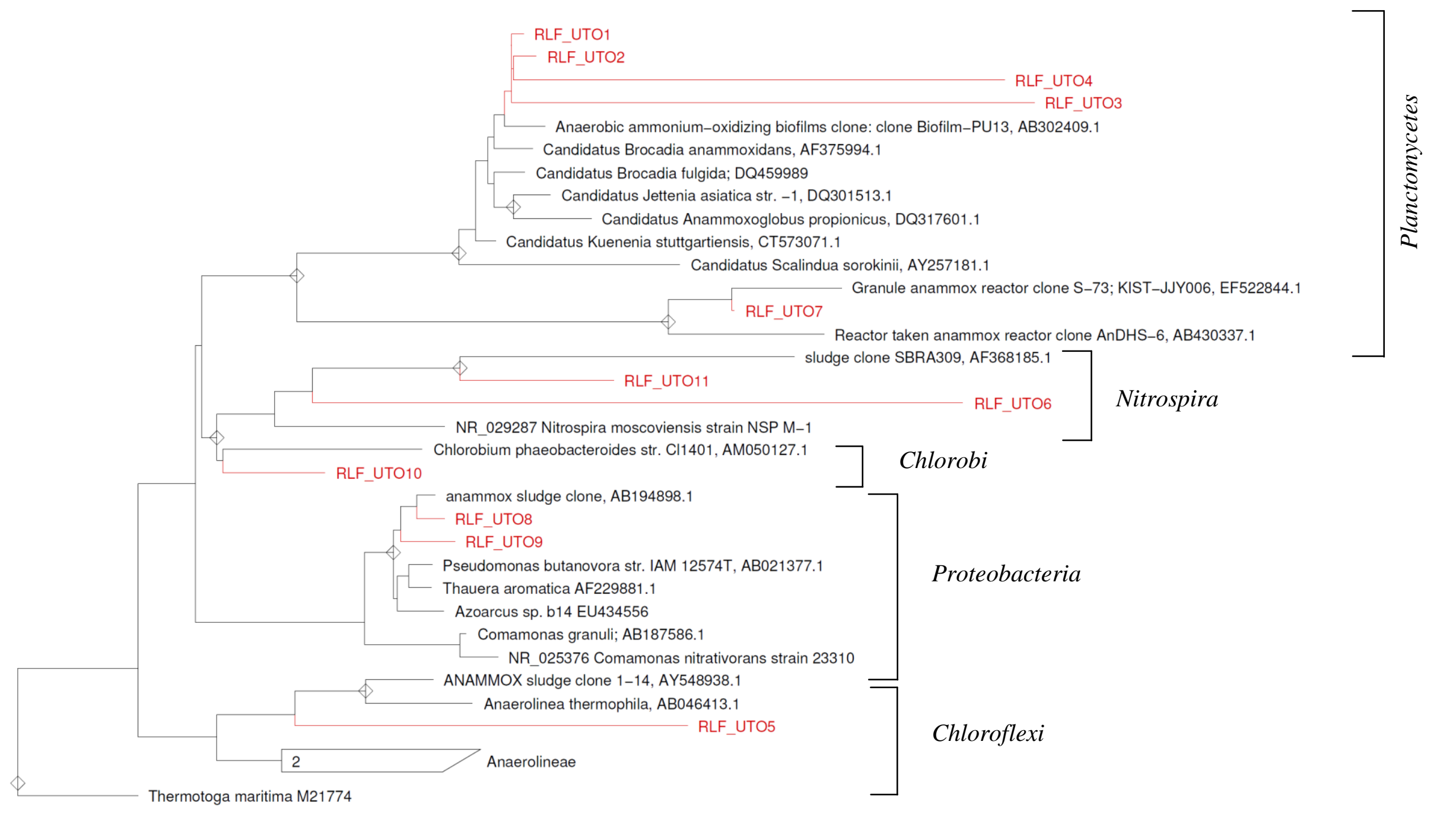

Figura 65. Árvore filogenética baseada em fragmento do gene rRNA 16S das 11 UTOs a partir de sequências encontradas nas amostras do RLF. Thermotoga maritima foi utilizada como grupo-externo, a barra indica dez substituições de em 100 nucleotídeos. Árvore construída pelo programa ARB com filtro LanemaskPH 


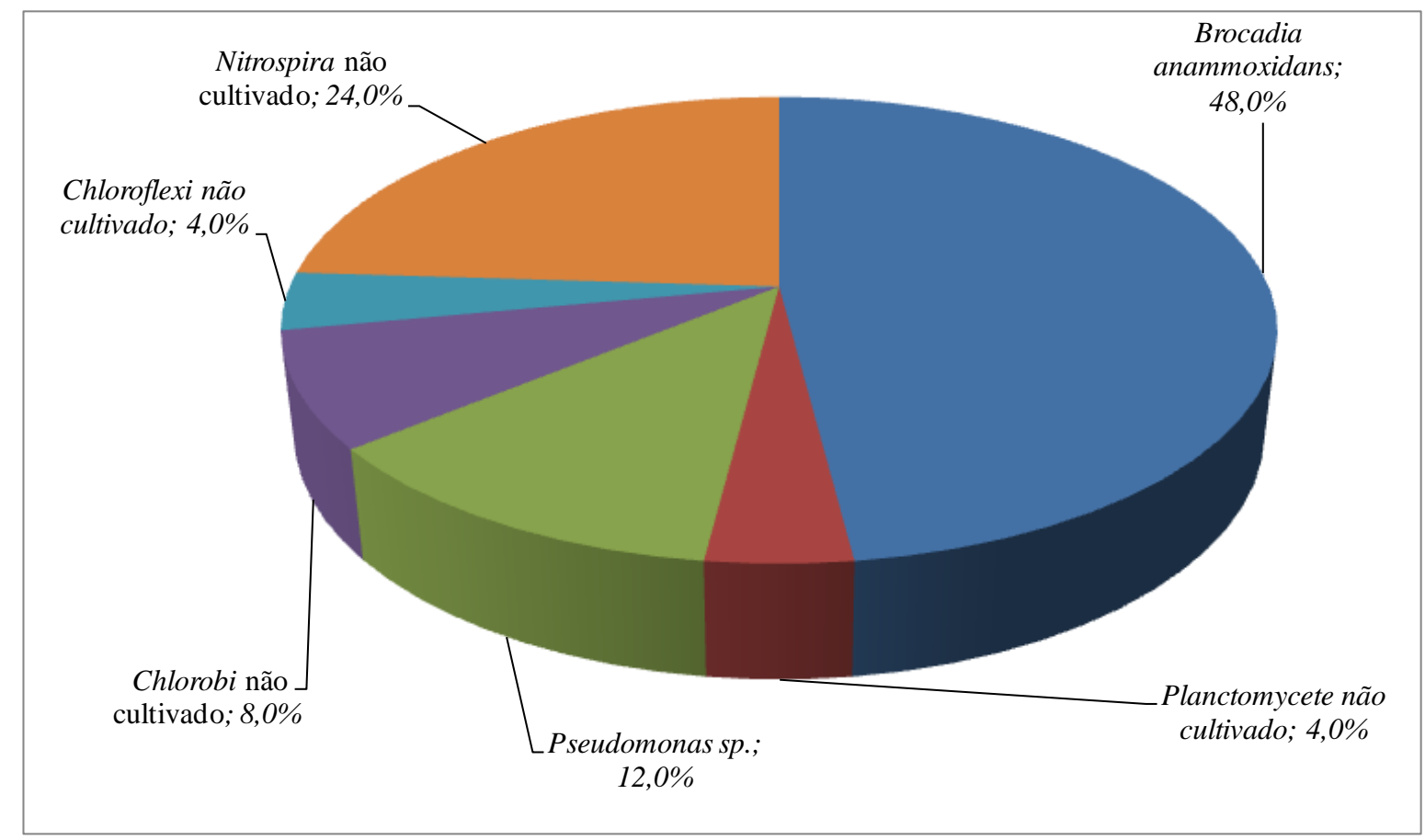

Figura 66. Constituição da comunidade microbiana presente no RLF com 139 dias de operação.

Microrganismo mais próximo filogeneticamente; porcentagem em relação à comunidade

\subsubsection{Análise Filogenética Comparativa dos Reatores}

A Figura 67 mostra A árvore filogenética de todas as UTOs obtidas para o RBS, com 170 e 450 dias de operação, e RLF após 139 dias de operação estão apresentadas na Figura 65

Após 170 dias de operação do RBS foram encontradas duas UTOs (com uma sequência cada) relacionadas à Anammoxoglobus propionicus. Interessantemente, nenhuma das UTOs obtidas com 450 dias do RBS e no RLF se relacionou com $A$. propionicus.

As RLF_UTO3 e RLF_UTO4 (uma sequência cada) agruparam com $B$. anammoxidans. No entanto, a distância filogenética relativa entre as UTOs e a espécie em questão foi elevada, e pode ser que seja nova espécie Candidatus dentro do gênero Brocadia. Análise do gene RNAr 16S completo e da subunidade 23S são necessárias para se afirmar a existência de nova espécie.

A proporção da família Pseudomonadaceae não apresentou variação entre as UTOs encontradas no RBS e no RLF. A porcentagem foi $12,5 \%$ da comunidade no RBS (RBS_UTO12, RBS_UTO13 e RBS_UTO14) e 12\% da comunidade presente no RLF (RLF_UTO8 e RLF_UTO9). 
A proporção do grupo Chlorobi no RBS em relação ao RLF apresentou redução de $12 \%$ para $8 \%$, respectivamente.

O grupo que apresentou maior mudança na composição da comunidade foi o Chloroflexi, que sofreu redução de 25\% (no RBS) para 4\% no RLF. Os microrganismos pertencentes à este grupo estão relacionados à bactérias filamentosas (Cadilinea aerophila e Anaerolinea thermophila). Essa morfologia tem função fundamental na formação e manutenção dos grânulos. Em virtude da biomassa apresentar-se granulada no RBS, provavelmente, esse grupo teve dificuldades em manter-se no RLF em crescimento aderido no suporte inerte.

Nos reatores RBS e RLF, o grupo de microrganismos com principal atuação na conversão e remoção de nitrogênio foi relacionado às bactérias anammox. No entanto, tanto no RBS quanto no RLF, $12 \%$ da comunidade pertencia às bactérias desnitrificantes (Pseudomonas sp. e Comamonas sp. no RBS; e Pseudomonas no RLF), com atuação, principalmente, quando submetidas a elevada agitação (100 rpm). Nistrospira sp. triplicou sua proporção na comunidade de $8,33 \%$ no RBS para $24 \%$ no RLF. No entanto, não existem evidências de atuação significativa de Nitrospira sp. no ciclo do nitrogênio nos reatores. 


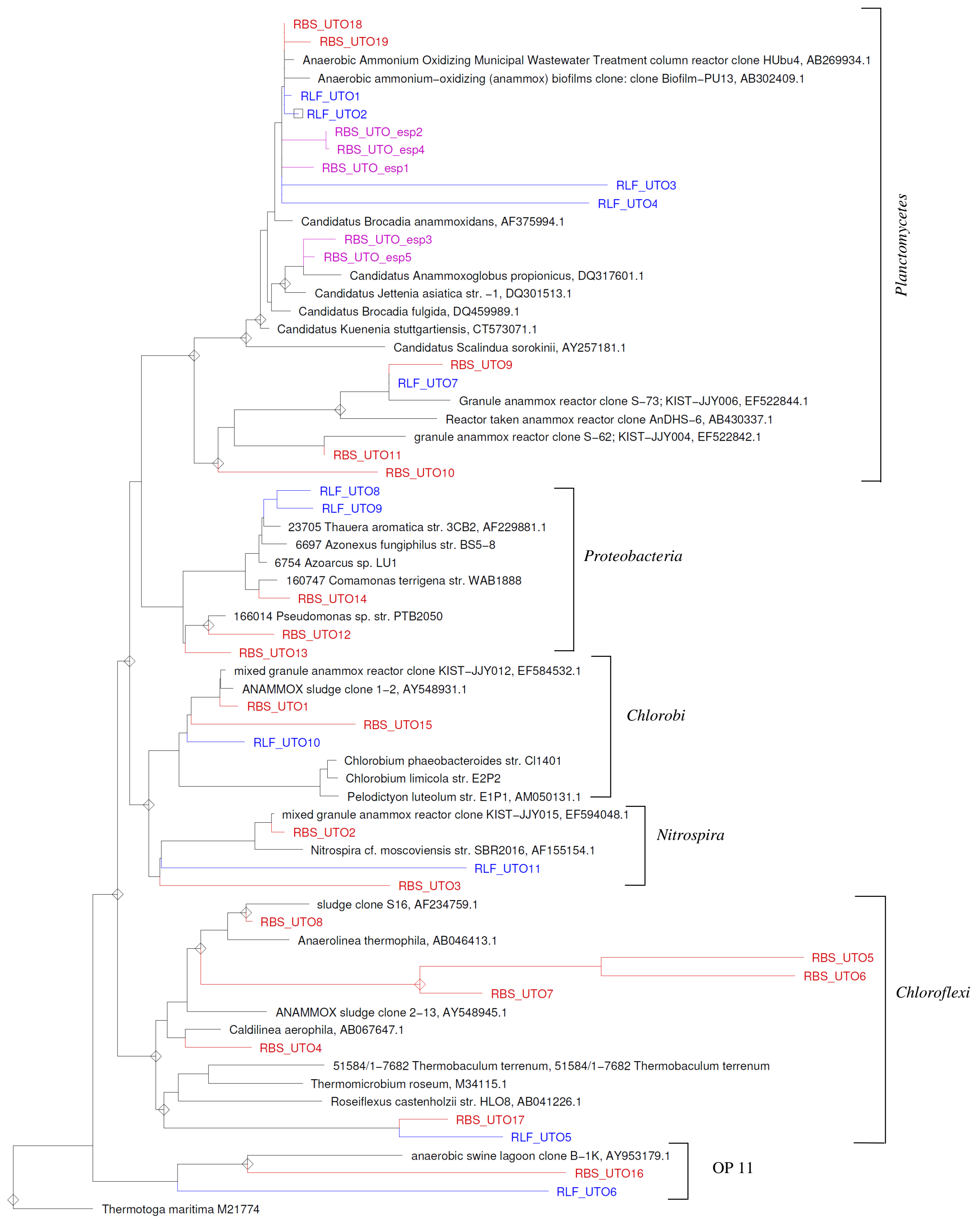

Figura 67. Árvore filogenética baseada em fragmento do gene rRNA 16S das UTOs a partir de sequências encontradas nas amostras do RBS com primers específico (em roxo) e com primers universais (em vermelho), e do RLF (em azul). Thermotoga maritima foi utilizada como grupo-externo, a barra indica dez substituições de em 100 nucleotídeos. Árvore construída pelo programa ARB

com filtro LanemaskPH 


\section{Conclusões}

Pode-se afirmar que a hipótese desta tese foi corroborada. O enriquecimento da biomassa capaz de realizar oxidação anaeróbia de amônio a partir de lodo nitrificantedesnitrificante foi obtido corroborando a hipótese proposta. Pode-se concluir que ocorreu estabelecimento de biofilme nitrificante-anammox em reator de leito fixo (RLF), pois houve remoção de nitrogênio amoniacal em condições aeróbias, e ainda foi possível a retomada da atividade anammox em condições anaeróbias, ou seja, a biomassa permaneceu com baixa atividade anammox. No entanto, as remoções de nitrogênio $(19,2 \%)$ não foram satisfatórias.

Houve diferença significativa na nitrificação sem adição de micronutrientes (com adição de Fe), do ponto de vista estatístico, entre os tratamentos, Q1 igual a Q3 e diferente de Q2. O quimiostato controle negativo (Q2) apresentou perda de 49,3\% de sólidos totais voláteis em 109 dias de operação.

Além disso, também podem ser concluídos alguns aspectos, listados abaixo:

- O reator operado em bateladas sequenciais foi adequado para enriquecimento de biomassa anammox a partir de lodo nitrificante-desnitrificante de indústria produtora de aminoácido com 89 dias de operação;

- Obteve-se eficiência de conversão de nitrogênio de 98,5\% e carga nitrogenada removida média de $1.267,9 \pm 5,9 \mathrm{~g} \mathrm{~N} / \mathrm{m}^{3}$ dia, para CNA de $1.405,7 \mathrm{~g} \mathrm{~N} / \mathrm{m}^{3}$ dia no reator operado em bateladas sequenciais. Portanto, essa configuração de reator é eficiente para enriquecimento e também para operação visando remoção de nitrogênio;

- A temperatura influenciou linearmente a atividade anammox especifica (AAE) entre 20 e $35^{\circ} \mathrm{C}$, e ocorreu aumento brusco da AAE a $37^{\circ} \mathrm{C}$;

- Observou-se tendência à diminuição dos valores de AAE em função do aumento

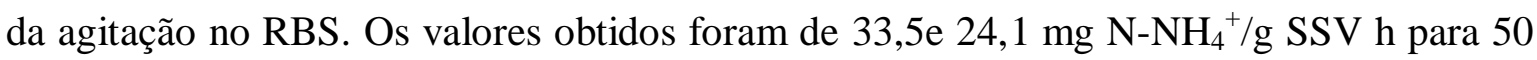
e $150 \mathrm{rpm}\left(0,008018 \mathrm{~kW} / \mathrm{m}^{3}\right.$ e $\left.0,216474 \mathrm{~kW} / \mathrm{m}^{3}\right)$, respectivamente; 
- Foi observado aumento do valor do parâmetro cinético $\mathrm{kNO}_{2}^{-}$no ensaio com

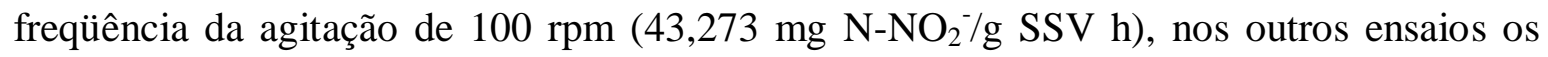
valores mantiveram-se praticamente constantes, variando de 34,8 a $36,9 \mathrm{mg} \mathrm{N}-\mathrm{NO}_{2}{ }^{-} / \mathrm{g} \mathrm{SSV}$ h, para 50 e $150 \mathrm{rpm}$, respectivamente

- Ocorreu desnitrificação no ensaio de AAE com freqüência de agitação de 100 $\mathrm{rpm}\left(0,06414 \mathrm{~kW} /{ }^{\mathrm{m} 3}\right)$ e, provavelmente, por microrganismos relacionados à Pseudomonas sp. e Comamonas sp. presentes no RBS;

- A atividade anammox específica máxima (AAEM) ocorreu no ensaio da biomassa submetida a $50 \mathrm{rpm}$ e $37^{\circ} \mathrm{C}$ e foi $33,5 \mathrm{mg} \mathrm{N}-\mathrm{NH}_{4}{ }^{+} / \mathrm{g} \mathrm{SSV}$ h, com concentrações iniciais próximas às estequiométricas $(1: 1,31)$; ou seja, de $219 \mathrm{mg} \mathrm{N}-\mathrm{NH}_{4}{ }^{+} / \mathrm{L}$ e $289 \mathrm{mg} \mathrm{N}-$ $\mathrm{NO}_{2}{ }^{-} / \mathrm{L}$

- A configuração do reator de leito fixo foi extremamente adequada para remoção de nitrogênio em condições anammox e obteve-se eficiência de conversão de nitrogênio de 97,6\% e carga nitrogenada removida média de 598,5 $\pm 22,5 \mathrm{~g} \mathrm{~N} / \mathrm{m}^{3}$ dia com 139 dias de operação;

- As morfologias encontradas nos reatores em batelada e de leito fixo foram semelhantes às encontradas em estudos com biomassa submetida a condições similares às deste estudo;

- Foram encontradas três UTOs com elevada similaridade com Brocadia anammoxidans e, duas UTOs com similaridade de 99\% a Anammoxoglobus propionicus, após 170 dias de operação do RBS;

- As bactérias encontradas no RBS com 450 dias de operação foram semelhantes à B. anammoxidans, Planctomycetes não cultivados, Pseudomonas sp. e Comamonas sp.), Chlorobi, Nitrospira, filo Chloroflexi (Caldilinea aerophila, Anaerolinea thermophila) e clones relacionados ao filo candidato OP 11;

- A composição encontrada no RLF com 139 dias de operação (final da fase anammox) foi relacionada à $B$. anammoxidans, Planctomycetes não cultivados, Proteobacterias, Chlorobi, Nitrospira, e ao filo Chloroflexi;

- Pelas análises biomoleculares, pode-se concluir que a configuração de reator de leito fixo com biomassa aderida em PEBD selecionou positivamente microrganismos anammox e Nitrospira e negativamente filamentos relacionados ao filo Chloroflexi; 


\section{REFERÊNCIAS BIBLIOGRÁFICAS}

ABELING, U.; SEYFRIED, C. F. Anaerobic-aerobic treatment of high-strength ammonium waste-water - nitrogen removal via nitrite. Water Science and Technology, v. 26, n. 5-6, p. 1007-1015, 1992.

AHN, Y. H. Sustainable nitrogen elimination biotechnologies: A review. Process Biochemistry, v. 41, n. 8, Aug, p. 1709-1721, 2006.

ANTHONISEN, A. C.; LOEHR, R. C.; PRAKASAM, T. B. S.; SRINATH, E. G. Inhibition of nitrification by ammonia and nitrous-acid. Journal Water Pollution Control Federation, v. 48, n. 5, p. 835-852, 1976.

APHA. Standard methods for the examination of water and wastewater. 19th ed. . ed. Washington, DC, USA, 2005

ARROJO, B.; MOSQUERA-CORRAL, A.; CAMPOS, J. L.; MENDEZ, R. Effects of mechanical stress on anammox granules in a sequencing batch reactor (sbr). Journal of Biotechnology, v. 123, n. 4, Jun, p. 453-463, 2006.

BOCK, E.; SCHMIDT, I.; STUVEN, R.; ZART, D. Nitrogen loss caused by denitrifying nitrosomonas cells using ammonium or hydrogen as electron-donors and nitrite as electron-acceptor. Archives of Microbiology, v. 163, n. 1, p. 16-20, 1995.

BOCK, E.; WAGNER, M. Oxidation of inorganic nitrogen compounds as an energy source 3rd ed. ed. New York: Springer New York, v. Volume 2: Ecophysiology and Biochemistry, 2006. 457-495 p. (The prokaryotes)

BRASIL. Resolução no 357 , de 17 de março de 2005. Dispõe sobre a classificação dos corpos de água e diretrizes ambientais para o seu enquadramento, bem como estabelece as condições e padrões de lançamento de efluentes, e dá outras providências. 357/2005. Brasil: Diário Oficial da União 18/3/2005. Seção 1, p.58 a 63. 2005.

CHAMCHOI, N.; NITISORAVUT, S. Anammox enrichment from different conventional sludges. Chemosphere, v. 66, n. 11, p. 2225-2232, 2007.

DAIMS, H.; NIELSEN, J. L.; NIELSEN, P. H.; SCHLEIFER, K. H.; WAGNER, M. In situ characterization of nitrospira-like nitrite oxidizing bacteria active in wastewater treatment plants. Applied and Environmental Microbiology, v. 67, n. 11, p. 5273-5284, 2001.

DAIMS, H.; NIELSEN, P. H.; NIELSEN, J. L.; JURETSCHKO, S.; WAGNER, M. Novel nitrospira-like bacteria as dominant nitrite-oxidizers in biofilms from wastewater treatment 
plants: Diversity and in situ physiology. Water Science and Technology, v. 41, n. 4-5, p. 85-90, 2000.

DALSGAARD, T.; THAMDRUP, B.; CANFIELD, D. E. Anaerobic ammonium oxidation (anammox) in the marine environment. Research in Microbiology, v. 156, n. 4, May, p. 457-464, 2005.

DAMSTE, J. S. S.; STROUS, M.; RIJPSTRA, W. I. C.; HOPMANS, E. C.; GEENEVASEN, J. A. J.; VAN DUIN, A. C. T.; VAN NIFTRIK, L. A.; JETTEN, M. S. M. Linearly concatenated cyclobutane lipids form a dense bacterial membrane. Nature, v. 419, n. 6908, Oct, p. 708-712, 2002.

DANCHIN, A.; MEDIGUE, C.; GASCUEL, O.; SOLDANO, H.; HENAUT, A. From data banks to data-bases. Research in Microbiology, v. 142, n. 7-8, p. 913-916, 1991.

DAPENA-MORA, A.; CAMPOS, J. L.; MOSQUERA-CORRAL, A.; JETTEN, M. S. M.; MENDEZ, R. Stability of the anammox process in a gas-lift reactor and a sbr. Journal of Biotechnology, v. 110, n. 2, May, p. 159-170, 2004a.

DAPENA-MORA, A.; CAMPOS, J. L.; MOSQUERA-CORRAL, A.; MENDEZ, R. Anammox process for nitrogen removal from anaerobically digested fish canning effluents. Water Science and Technology, v. 53, n. 12, p. 265-274, 2006.

DAPENA-MORA, A.; VAN HULLE, S. W. H.; CAMPOS, J. L.; MENDEZ, R.; VANROLLEGHEM, P. A.; JETTEN, M. Enrichment of anammox biomass from municipal activated sludge: Experimental and modelling results. Journal of Chemical Technology and Biotechnology, v. 79, n. 12, Dec, p. 1421-1428, $2004 \mathrm{~b}$.

DESANTIS, T. Z.; HUGENHOLTZ, P.; KELLER, K.; BRODIE, E. L.; LARSEN, N.; PICENO, Y. M.; PHAN, R.; ANDERSEN, G. L. Nast: A multiple sequence alignment server for comparative analysis of 16s rrna genes. Nucleic Acids Research, v. 34, p. W394W399, 2006.

EGLI, K.; BOSSHARD, F.; WERLEN, C.; LAIS, P.; SIEGRIST, H.; ZEHNDER, A. J. B.; VAN DER MEER, J. R. Microbial composition and structure of a rotating biological contactor biofilm treating ammonium-rich wastewater without organic carbon. Microbial Ecology, v. 45, n. 4, May, p. 419-432, 2003.

EGLI, K.; FANGER, U.; ALVAREZ, P. J. J.; SIEGRIST, H.; VAN DER MEER, J. R.; ZEHNDER, A. J. B. Enrichment and characterization of an anammox bacterium from a rotating biological contactor treating ammonium-rich leachate. Archives of Microbiology, v. 175, n. 3, Mar, p. 198-207, 2001.

EHRICH, S.; BEHRENS, D.; LEBEDEVA, E.; LUDWIG, W.; BOCK, E. A new obligately chemolithoautotrophic, nitrite-oxidizing bacterium, nitrospira-moscoviensis spnov and its phylogenetic relationship. Archives of Microbiology, v. 164, n. 1, p. 16-23, 1995.

FDZ-POLANCO, F.; FDZ-POLANCO, M.; FERNANDEZ, N.; URUENA, M. A.; GARCIA, P. A.; VILLAVERDE, S. New process for simultaneous removal of nitrogen 
and sulphur under anaerobic conditions. Water Research, v. 35, n. 4, p. 1111-1114, 2001.

FRANCIS, C. A.; BEMAN, J. M.; KUYPERS, M. M. M. New processes and players in the nitrogen cycle: The microbial ecology of anaerobic and archaeal ammonia oxidation. Isme Journal, v. 1, p. 19-27, 2007.

FREITAG, A.; RUDERT, M.; BOCK, E. Growth of nitrobacter by dissimilatoric nitrate reduction. Fems Microbiology Letters, v. 48, n. 1-2, p. 105-109, 1987.

FRIGAARD, N. U.; CHEW, A. G. M.; LI, H.; MARESCA, J. A.; BRYANT, D. A. Chlorobium tepidum: Insights into the structure, physiology, and metabolism of a green sulfur bacterium derived from the complete genome sequence. Photosynthesis Research, v. 78, n. 2, p. 93-117, 2003.

GLASS, C.; SILVERSTEIN, J.; OH, J. Inhibition of denitrification in activated sludge by nitrite. Water Environment Research, v. 69, n. 6, p. 1086-1093, 1997.

GRUNDITZ, C.; GUMAELIUS, L.; DALHAMMAR, G. Comparison of inhibition assays using nitrogen removing bacteria: Application to industrial wastewater. Water Research, v. 32, n. 10, p. 2995-3000, 1998.

GUVEN, D.; DAPENA, A.; KARTAL, B.; SCHMID, M. C.; MAAS, B.; VAN DE PASSCHOONEN, K.; SOZEN, S.; MENDEZ, R.; OP DEN CAMP, H. J. M.; JETTEN, M. S. M.; STROUS, M.; SCHMIDT, I. Propionate oxidation by and methanol inhibition of anaerobic ammonium-oxidizing bacteria. Applied and Environmental Microbiology, v. 71, n. 2, Feb, p. 1066-1071, 2005.

HAO, X. D.; HEIJNEN, J. J.; VAN LOOSDRECHT, M. C. M. Sensitivity analysis of a biofilm model describing a one-stage completely autotrophic nitrogen removal (canon) process. Biotechnology and Bioengineering, v. 77, n. 3, Feb, p. 266-277, 2002.

HARRIS, J. K.; KELLEY, S. T.; PACE, N. R. New perspective on uncultured bacterial phylogenetic division op11. Applied and Environmental Microbiology, v. 70, n. 2, Feb, p. 845-849, 2004.

HUGENHOLTZ, P.; GOEBEL, B. M.; PACE, N. R. Impact of culture-independent studies on the emerging phylogenetic view of bacterial diversity. Journal of Bacteriology, v. 180, n. 18, Sep, p. 4765-4774, 1998.

IMHOFF, J. F. Phylogenetic taxonomy of the family chlorobiaceae on the basis of 16s rrna and fmo (fenna matthews-olson protein) gene sequences. International Journal of Systematic and Evolutionary Microbiology, v. 53, Jul, p. 941-951, 2003.

JENKINS, D.; RICHARD, M. G.; DAIGGER, G. T. Manual on the causes and control of activated sludge bulking, foaming and other solids separation problems. 3rd Edition. ed. London: Lewis Publishers, 2003

JETTEN, M.; SCHMID, M.; VAN DE PAS-SCHOONEN, K.; DAMSTE, J. S. S.; STROUS, M. Anammox organisms: Enrichment, cultivation, and environmental analysis. Environmental Microbiology, v. 397, p. 34-57, 2005. 
JETTEN, M. S. M.; STROUS, M.; VAN DE PAS-SCHOONEN, K. T.; SCHALK, J.; VAN DONGEN, U.; VAN DE GRAAF, A. A.; LOGEMANN, S.; MUYZER, G.; VAN LOOSDRECHT, M. C. M.; KUENEN, J. G. The anaerobic oxidation of ammonium. Fems Microbiology Reviews, v. 22, n. 5, Dec, p. 421-437, 1998.

JETTEN, M. S. M.; VAN NIFTRIK, L.; STROUS, M.; KARTAL, B.; KELTJENS, J. T.; OP DEN CAMP, H. J. M. Biochemistry and molecular biology of anammox bacteria. Critical Reviews in Biochemistry and Molecular Biology, v. 44, n. 2-3, Jun, p. 65-84, 2009.

JETTEN, M. S. M.; WAGNER, M.; FUERST, J.; VAN LOOSDRECHT, M.; KUENEN, G.; STROUS, M. Microbiology and application of the anaerobic ammonium oxidation ('anammox') process. Current Opinion in Biotechnology, v. 12, n. 3, Jun, p. 283-288, 2001.

JETTEN, M. S. M. V. D., L. G. J. M.; VAN LOOSDRECHT, M. C. M The combined sharon/anammox process. London: IWA Publishing, 2001

KARTAL, B.; KUYPERS, M. M. M.; LAVIK, G.; SCHALK, J.; DEN CAMP, H.; JETTEN, M. S. M.; STROUS, M. Anammox bacteria disguised as denitrifiers: Nitrate reduction to dinitrogen gas via nitrite and ammonium. Environmental Microbiology, v. 9, n. 3, Mar, p. 635-642, 2007a.

KARTAL, B.; RATTRAY, J.; VAN NIFTRIK, L. A.; VAN DE VOSSENBERG, J.; SCHMID, M. C.; WEBB, R. I.; SCHOUTEN, S.; FUERST, J. A.; DAMSTE, J. S. S.; JETTEN, M. S. M.; STROUS, M. Candidatus "Anammoxoglobus propionicus" A new propionate oxidizing species of anaerobic ammonium oxidizing bacteria. Systematic and Applied Microbiology, v. 30, n. 1, Jan, p. 39-49, $2007 \mathrm{~b}$.

KHIN, T.; ANNACHHATRE, A. P. Novel microbial nitrogen removal processes. Biotechnology Advances, v. 22, n. 7, Sep, p. 519-532, 2004.

KIM, D. J.; CHANG, J. S.; LEE, D. I.; HAN, D. W.; YOO, I. K.; CHA, G. C. Nitrification of high strength ammonia wastewater and nitrite accumulation characteristics. Water Science and Technology, v. 47, n. 11, p. 45-51, 2003.

KUENEN, J. G. Anammox bacteria: From discovery to application. Nature Reviews Microbiology, v. 6, n. 4, p. 320-326, 2008.

KUYPERS, M. M. M.; SLIEKERS, A. O.; LAVIK, G.; SCHMID, M.; JORGENSEN, B. B.; KUENEN, J. G.; DAMSTE, J. S. S.; STROUS, M.; JETTEN, M. S. M. Anaerobic ammonium oxidation by anammox bacteria in the black sea. Nature, v. 422, n. 6932, Apr, p. 608-611, 2003.

LAANBROEK, H. J.; GERARDS, S. Competition for limiting amounts of oxygen between nitrosomonas-europaea and nitrobacter-winogradskyi grown in mixed continuous cultures. Archives of Microbiology, v. 159, n. 5, p. 453-459, 1993.

LARKIN, M. A.; BLACKSHIELDS, G.; BROWN, N. P.; CHENNA, R.; MCGETTIGAN, P. A.; MCWILLIAM, H.; VALENTIN, F.; WALLACE, I. M.; WILM, A.; LOPEZ, R.; THOMPSON, J. D.; GIBSON, T. J.; HIGGINS, D. G. Clustal w and clustal x version 2.0. 
Bioinformatics, v. 23, p. 2947-2948, 2007.

LINDSAY, M. R.; WEBB, R. I.; STROUS, M.; JETTEN, M. S.; BUTLER, M. K.; FORDE, R. J.; FUERST, J. A. Cell compartmentalisation in planctomycetes: Novel types of structural organisation for the bacterial cell. Archives of Microbiology, v. 175, n. 6, Jun, p. 413-429, 2001.

LOPEZ, H.; PUIG, S.; GANIGUE, R.; RUSCALLEDA, M.; BALAGUER, M. D.; COLPRIM, J. Start-up and enrichment of a granular anammox sbr to treat high nitrogen load wastewaters. Journal of Chemical Technology and Biotechnology, v. 83, n. 3, p. 233 $241,2008$.

LUDWIG, W.; STRUNK, O.; WESTRAM, R.; RICHTER, L.; MEIER, H.; YADHUKUMAR; BUCHNER, A.; LAI, T.; STEPPI, S.; JOBB, G.; FORSTER, W.; BRETTSKE, I.; GERBER, S.; GINHART, A. W.; GROSS, O.; GRUMANN, S.; HERMANN, S.; JOST, R.; KONIG, A.; LISS, T.; LUSSMANN, R.; MAY, M.; NONHOFF, B.; REICHEL, B.; STREHLOW, R.; STAMATAKIS, A.; STUCKMANN, N.; VILBIG, A.; LENKE, M.; LUDWIG, T.; BODE, A.; SCHLEIFER, K. H. Arb: A software environment for sequence data. Nucleic Acids Research, v. 32, n. 4, Feb, p. 1363 1371, 2004.

MANSKE, A. K.; GLAESER, J.; KUYPERS, M. A. M.; OVERMANN, J. Physiology and phylogeny of green sulfur bacteria forming a monospecific phototrophic assemblage at a depth of 100 meters in the black sea. Applied and Environmental Microbiology, v. 71, $\mathrm{n}$. 12, Dec, p. 8049-8060, 2005.

MULDER, A.; VANDEGRAAF, A. A.; ROBERTSON, L. A.; KUENEN, J. G. Anaerobic ammonium oxidation discovered in a denitrifying fluidized-bed reactor. Fems Microbiology Ecology, v. 16, n. 3, Mar, p. 177-183, 1995.

NG, A.; MELVIN, W. T.; HOBSON, P. N. Identification of anaerobic digester bacteria using a polymerase chain-reaction method. Bioresource Technology, v. 47, n. 1, p. 73-80, 1994.

NOWAK, O.; SVARDAL, K.; KROISS, H. The impact of phosphorus deficiency on nitrification - case study of a biological pretreatment plant for rendering plant effluent. Water Science and Technology, v. 34, n. 1-2, p. 229-236, 1996.

PAREDES, D.; KUSCHK, P.; MBWETTE, T. S. A.; STANGE, F.; MULLER, R. A.; KOSER, H. New aspects of microbial nitrogen transformations in the context of wastewater treatment - a review. Engineering in Life Sciences, v. 7, n. 1, Feb, p. 13-25, 2007.

PENG, Y. Z.; ZHU, G. B. Biological nitrogen removal with nitrification and denitrification via nitrite pathway. Applied Microbiology and Biotechnology, v. 73, n. 1, p. 15-26, 2006.

PHILIPS, S.; VERSTRAETE, W. Effect of repeated addition of nitrite to semi-continuous activated sludge reactors. Bioresource Technology, v. 80, n. 1, p. 73-82, 2001.

PICIOREANU, C.; VANLOOSDRECHT, M. C. M.; HEIJNEN, J. J. Modelling the effect 
of oxygen concentration on nitrite accumulation in a biofilm airlift suspension reactor. Water Science and Technology, v. 36, n. 1, p. 147-156, 1997.

PYNAERT, K.; SMETS, B. F.; WYFFELS, S.; BEHEYDT, D.; SICILIANO, S. D.; VERSTRAETE, W. Characterization of an autotrophic nitrogen-removing biofilm from a highly loaded lab-scale rotating biological contactor. Applied and Environmental Microbiology, v. 69, n. 6, p. 3626-3635, 2003.

QUAN, Z. X.; RHEE, S. K.; ZUO, J. E.; YANG, Y.; BAE, J. W.; PARK, J. R.; LEE, S. T.; PARK, Y. H. Diversity of ammonium-oxidizing bacteria in a granular sludge anaerobic ammonium-oxidizing (anammox) reactor. Environmental Microbiology, v. 10, n. 11, Nov, p. 3130-3139, 2008.

SCHLOSS, P. D.; HANDELSMAN, J. Introducing dotur, a computer program for defining operational taxonomic units and estimating species richness. Applied and Environmental Microbiology, v. 71, n. 3, p. 1501-1506, 2005.

SCHMID, M.; TWACHTMANN, U.; KLEIN, M.; STROUS, M.; JURETSCHKO, S.; JETTEN, M.; METZGER, J. W.; SCHLEIFER, K. H.; WAGNER, M. Molecular evidence for genus level diversity of bacteria capable of catalyzing anaerobic ammonium oxidation. Systematic and Applied Microbiology, v. 23, n. 1, p. 93-106, 2000.

SCHMID, M.; WALSH, K.; WEBB, R.; RIJPSTRA, W. I. C.; VAN DE PASSCHOONEN, K.; VERBRUGGEN, M. J.; HILL, T.; MOFFETT, B.; FUERST, J.; SCHOUTEN, S.; DAMSTE, J. S. S.; HARRIS, J.; SHAW, P.; JETTEN, M.; STROUS, M. Candidatus "Scalindua brodae", sp nov., candidatus "Scalindua wagneri", sp nov., two new species of anaerobic ammonium oxidizing bacteria. Systematic and Applied Microbiology, v. 26, n. 4, Nov, p. 529-538, 2003.

SCHMID, M. C.; RISGAARD-PETERSEN, N.; VAN DE VOSSENBERG, J.; KUYPERS, M. M. M.; LAVIK, G.; PETERSEN, J.; HULTH, S.; THAMDRUP, B.; CANFIELD, D.; DALSGAARD, T.; RYSGAARD, S.; SEJR, M. K.; STROUS, M.; DEN CAMP, H.; JETTEN, M. S. M. Anaerobic ammonium-oxidizing bacteria in marine environments: Widespread occurrence but low diversity. Environmental Microbiology, v. 9, n. 6, Jun, p. 1476-1484, 2007.

SCHOUTEN, S.; STROUS, M.; KUYPERS, M. M. M.; RIJPSTRA, W. I. C.; BAAS, M.; SCHUBERT, C. J.; JETTEN, M. S. M.; DAMSTE, J. S. S. Stable carbon isotopic fractionations associated with inorganic carbon fixation by anaerobic ammonium-oxidizing bacteria. Applied and Environmental Microbiology, v. 70, n. 6, Jun, p. 3785-3788, 2004.

SEKIGUCHI, Y.; YAMADA, T.; HANADA, S.; OHASHI, A.; HARADA, H.; KAMAGATA, Y. Anaerolinea thermophila gen. Nov., sp nov and caldilinea aerophila gen. Nov., sp nov., novel filamentous thermophiles that represent a previously uncultured lineage of the domain bacteria at the subphylum level. International Journal of Systematic and Evolutionary Microbiology, v. 53, Nov, p. 1843-1851, 2003.

SLIEKERS, A. O.; DERWORT, N.; GOMEZ, J. L. C.; STROUS, M.; KUENEN, J. G.; JETTEN, M. S. M. Completely autotrophic nitrogen removal over nitrite in one single reactor. Water Research, v. 36, n. 10, May, p. 2475-2482, 2002. 
SLIEKERS, A. O.; THIRD, K. A.; ABMA, W.; KUENEN, J. G.; JETTEN, M. S. M. Canon and anammox in a gas-lift reactor. Fems Microbiology Letters, v. 218, n. 2, Jan, p. 339-344, 2003.

STROUS, M.; FUERST, J. A.; KRAMER, E. H. M.; LOGEMANN, S.; MUYZER, G.; VAN DE PAS-SCHOONEN, K. T.; WEBB, R.; KUENEN, J. G.; JETTEN, M. S. M. Missing lithotroph identified as new planctomycete. Nature, v. 400, n. 6743, Jul, p. 446449, 1999a.

STROUS, M.; HEIJNEN, J. J.; KUENEN, J. G.; JETTEN, M. S. M. The sequencing batch reactor as a powerful tool for the study of slowly growing anaerobic ammonium-oxidizing microorganisms. Applied Microbiology and Biotechnology, v. 50, n. 5, p. 589-596, 1998.

STROUS, M.; JETTEN, M. S. M. Anaerobic oxidation of methane and ammonium. Annual Review of Microbiology, v. 58, p. 99-117, 2004.

STROUS, M.; KUENEN, J. G.; FUERST, J. A.; WAGNER, M.; JETTEN, M. S. M. The anammox case - a new experimental manifesto for microbiological eco-physiology. Antonie Van Leeuwenhoek International Journal of General and Molecular Microbiology, v. 81, n. 1-4, p. 693-702, 2002.

STROUS, M.; KUENEN, J. G.; JETTEN, M. S. M. Key physiology of anaerobic ammonium oxidation. Applied and Environmental Microbiology, v. 65, n. 7, Jul, p. 32483250, 1999b.

STROUS, M.; PELLETIER, E.; MANGENOT, S.; RATTEI, T.; LEHNER, A.; TAYLOR, M. W.; HORN, M.; DAIMS, H.; BARTOL-MAVEL, D.; WINCKER, P.; BARBE, V.; FONKNECHTEN, N.; VALLENET, D.; SEGURENS, B.; SCHENOWITZ-TRUONG, C.; MEDIGUE, C.; COLLINGRO, A.; SNEL, B.; DUTILH, B. E.; OP DEN CAMP, H. J. M.; VAN DER DRIFT, C.; CIRPUS, I.; VAN DE PAS-SCHOONEN, K. T.; HARHANGI, H. R.; VAN NIFTRIK, L.; SCHMID, M.; KELTJENS, J.; VAN DE VOSSENBERG, J.; KARTAL, B.; MEIER, H.; FRISHMAN, D.; HUYNEN, M. A.; MEWES, H. W.; WEISSENBACH, J.; JETTEN, M. S. M.; WAGNER, M.; LE PASLIER, D. Deciphering the evolution and metabolism of an anammox bacterium from a community genome. Nature, v. 440, n. 7085, Apr, p. 790-794, 2006.

STROUS, M.; VANGERVEN, E.; KUENEN, J. G.; JETTEN, M. Effects of aerobic and microaerobic conditions on anaerobic ammonium-oxidizing (anammox) sludge. Applied and Environmental Microbiology, v. 63, n. 6, Jun, p. 2446-2448, 1997a.

STROUS, M.; VANGERVEN, E.; ZHENG, P.; KUENEN, J. G.; JETTEN, M. S. M. Ammonium removal from concentrated waste streams with the anaerobic ammonium oxidation (anammox) process in different reactor configurations. Water Research, v. 31, n. 8, Aug, p. 1955-1962, $1997 b$.

THIRD, K. A.; PAXMAN, J.; SCHMID, M.; STROUS, M.; JETTEN, M. S. M.; CORDRUWISCH, R. Enrichment of anammox from activated sludge and its application in the canon process. Microbial Ecology, v. 49, n. 2, Feb, p. 236-244, 2005. 
TSUSHIMA, I.; OGASAWARA, Y.; KINDAICHI, T.; SATOH, H.; OKABE, S. Development of high-rate anaerobic ammonium-oxidizing (anammox) biofilm reactors. Water Research, v. 41, n. 8, Apr, p. 1623-1634, 2007.

VAN DE GRAAF, A. A.; DEBRUIJN, P.; ROBERTSON, L. A.; JETTEN, M. S. M.; KUENEN, J. G. Metabolic pathway of anaerobic ammonium oxidation on the basis of n-15 studies in a fluidized bed reactor. Microbiology-Uk, v. 143, p. 2415-2421, 1997.

VAN DE GRAAF, A. A.; MULDER, A.; DEBRUIJN, P.; JETTEN, M. S. M.; ROBERTSON, L. A.; KUENEN, J. G. Anaerobic oxidation of ammonium is a biologically mediated process. Applied and Environmental Microbiology, v. 61, n. 4, Apr, p. 1246$1251,1995$.

VAN DE GRAAF, A. A. V.; DE BRUIJN, P.; ROBERTSON, L. A.; JETTEN, M. S. M.; KUENEN, J. G. Autotrophic growth of anaerobic ammonium-oxidizing micro-organisms in a fluidized bed reactor. Microbiology-Uk, v. 142, Aug, p. 2187-2196, 1996.

VAN DER STAR, W. R. L.; ABMA, W. R.; BLOMMERS, D.; MULDER, J. W.; TOKUTOMI, T.; STROUS, M.; PICIOREANU, C.; VAN LOOSDRECHT, M. C. M. Startup of reactors for anoxic ammonium oxidation: Experiences from the first full-scale anammox reactor in rotterdam. Water Research, v. 41, n. 18, p. 4149-4163, 2007.

VAN DER STAR, W. R. L.; MICLEA, A. I.; VAN DONGEN, U.; MUYZER, G.; PICIOREANU, C.; VAN LOOSDRECHT, M. C. M. The membrane bioreactor: A novel tool to grow anammox bacteria as free cells. Biotechnology and Bioengineering, v. 101, n. 2, Oct, p. 286-294, 2008a.

VAN DER STAR, W. R. L.; VAN DE GRAAF, M. J.; KARTAL, B.; PICIOREANU, C.; JETTEN, M. S. M.; VAN LOOSDRECHT, M. C. M. Response of anaerobic ammoniumoxidizing bacteria to hydroxylamine. Applied and Environmental Microbiology, v. 74, n. 14, Jul, p. 4417-4426, 2008b.

WONGCHONG, G. M.; LOEHR, R. C. Kinetics of microbial nitrification - nitrite-nitrogen oxidation. Water Research, v. 12, n. 8, p. 605-609, 1978.

YANG, L.; ALLEMAN, J. E. Investigation of batchwise nitrite buildup by an enriched nitrification culture. Water Science and Technology, v. 26, n. 5-6, p. 997-1005, 1992. 
APÊNDICE A - CURVAS DE CALIBRAÇÃo PELO MÉTODO FIA 


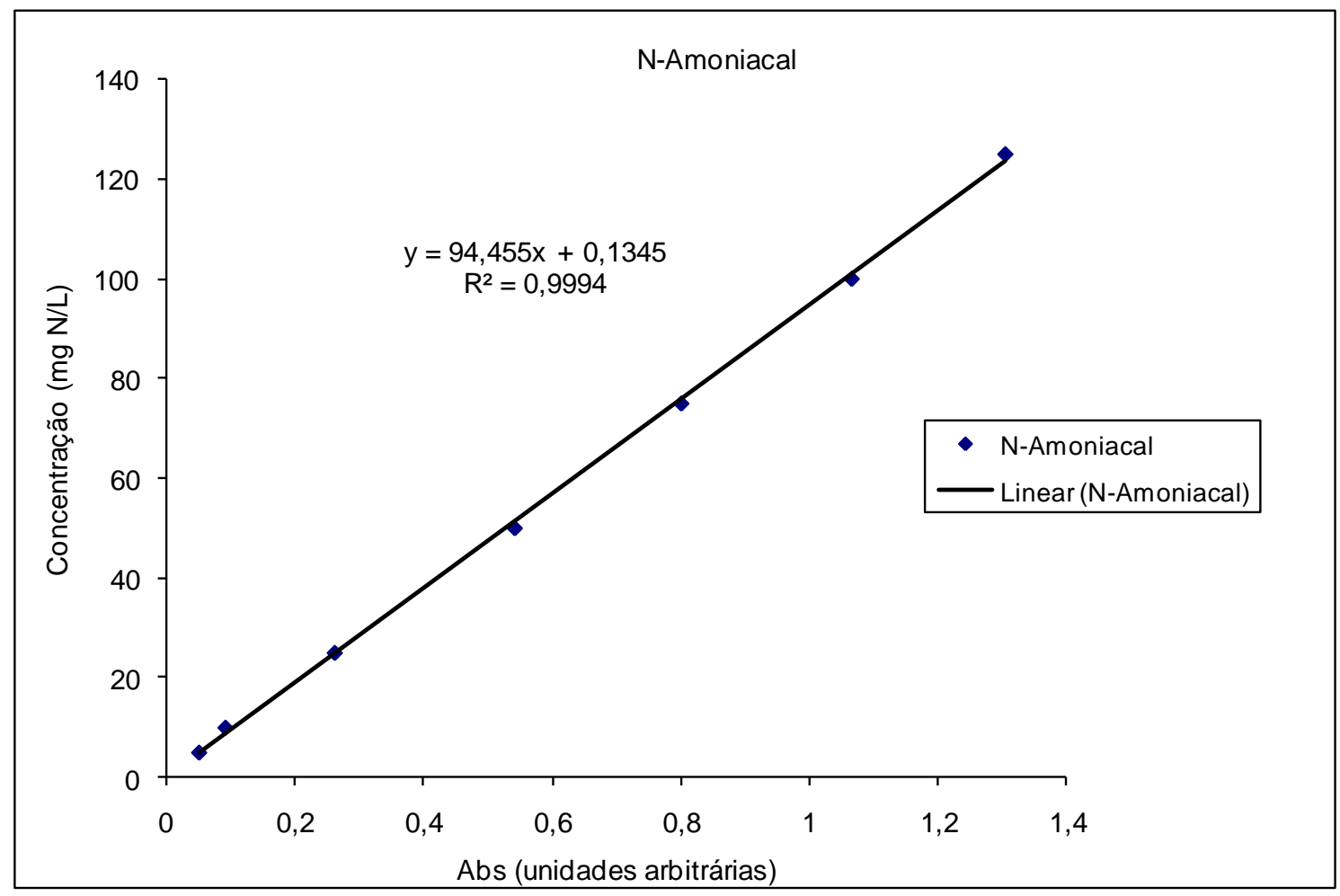

Figura A1. Concentração de Nitrogênio amoniacal em função da abs (690nm)

para padrões entre 5 e $125 \mathrm{mg} \mathrm{N}-\mathrm{NH}_{4}{ }^{+} / \mathrm{L}$

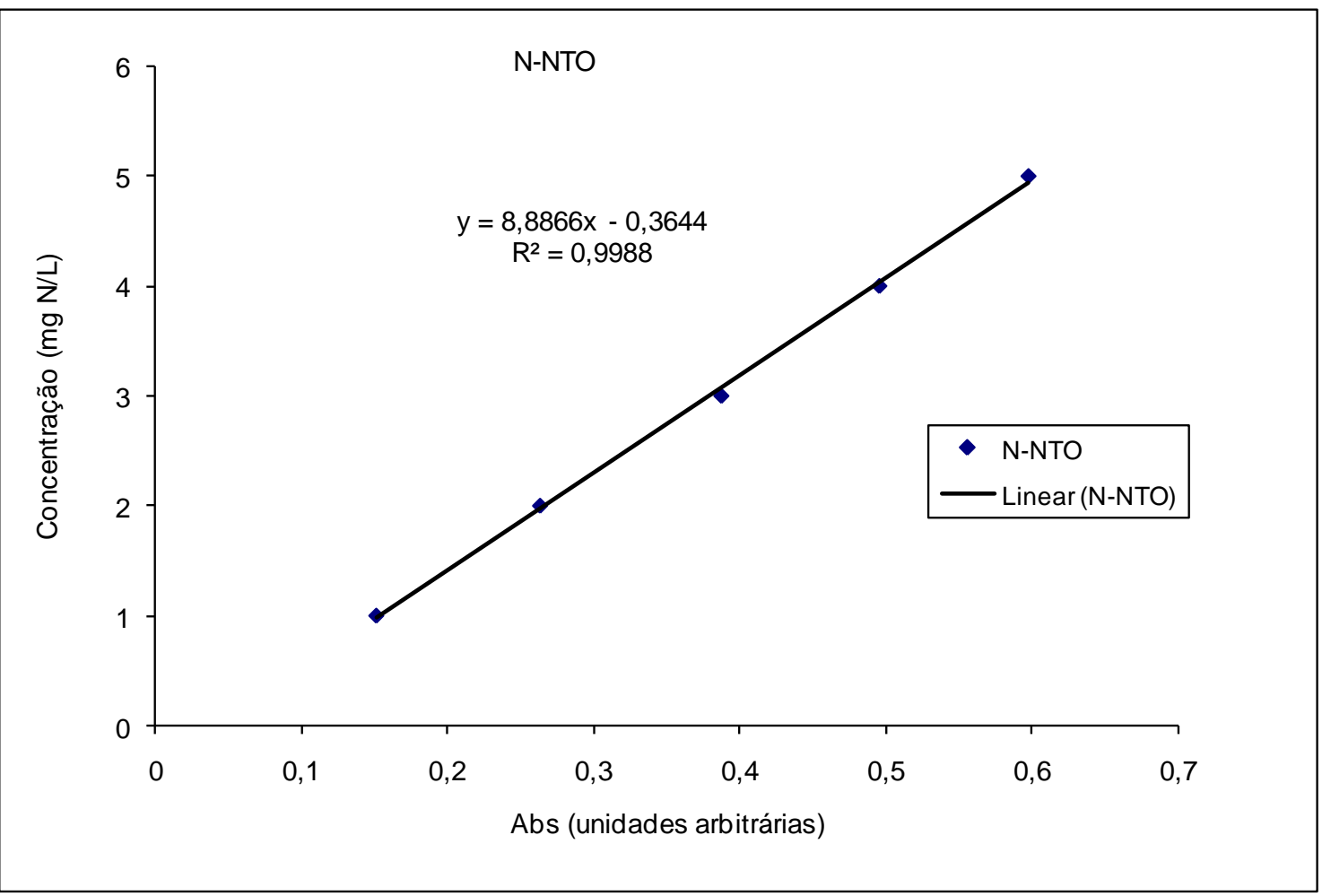

Figura A2. Concentração de Nitrogênio total oxidado (nitrito e nitrato) para função da abs (435nm) de padrões entre 1 a $5 \mathrm{mg} \mathrm{N}-\mathrm{NO}_{3}{ }^{-} / \mathrm{L}$ 


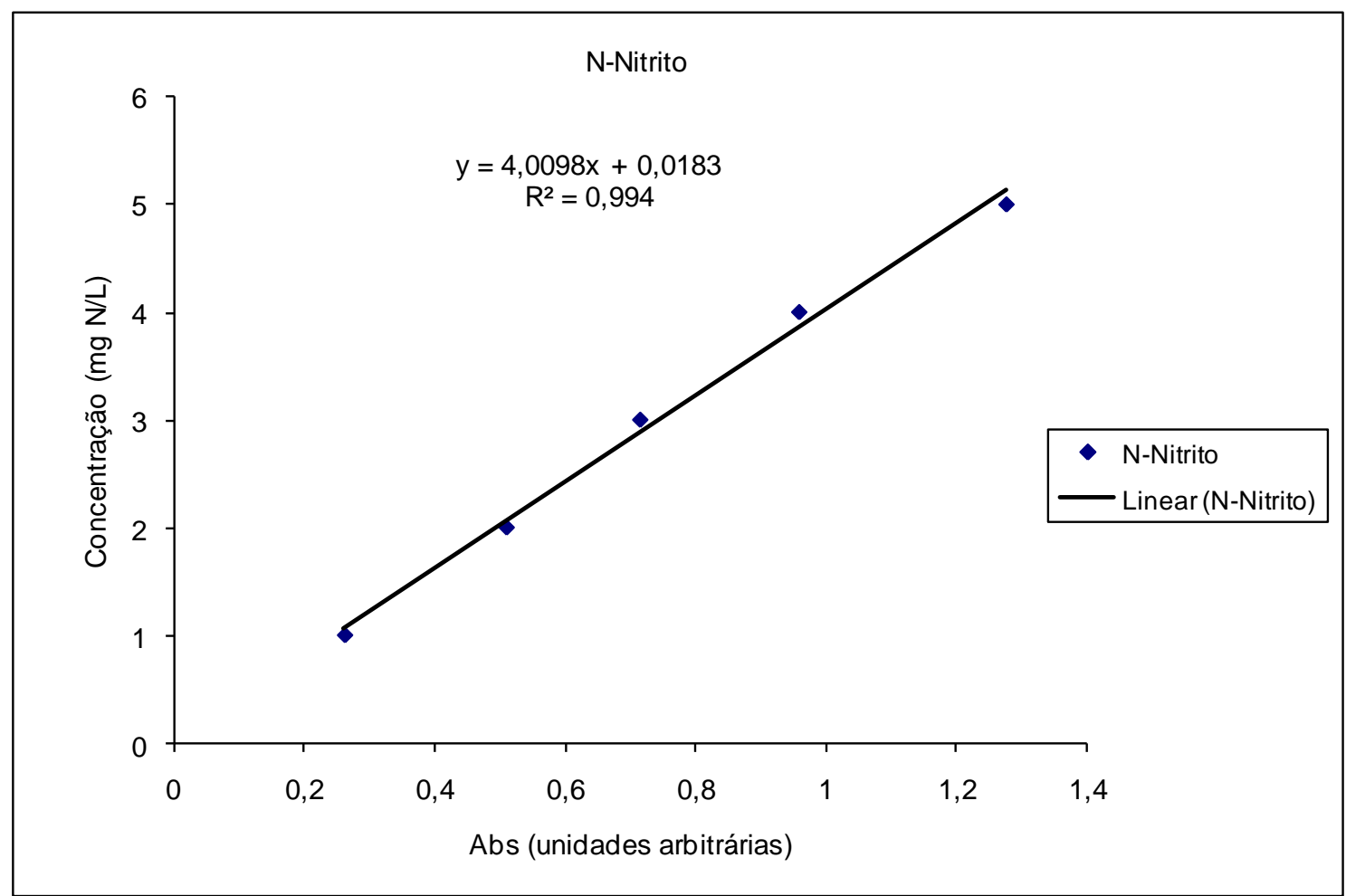

Figura A3. Concentração de Nitrito em função da abs (435nm) para padrões entre 1 a $5 \mathrm{mg} \mathrm{N}-\mathrm{NO}_{2}{ }^{-} / \mathrm{L}$ 
APÊNDICE B - TABELA DE ANOVA DO ENSAIO PARA VERIFICAÇÃO DE INFLUÊNCIA DE MICRONUTRIENTES 
Tabela B. ANOVA: fator duplo sem repetição para Q1, Q2 e Q3 entre os dias 11 e 69 (alfa $=0,05)$

\begin{tabular}{|c|c|c|c|c|c|c|}
\hline RESUMO & & Contagem & Soma & Média & Variância & \\
\hline & 11 & 3 & 295,4169 & 98,47231 & 0,061611 & \\
\hline & 16 & 3 & 281,5176 & 93,83919 & 33,11499 & \\
\hline & 19 & 3 & 276,702 & 92,23399 & 45,69294 & \\
\hline & 22 & 3 & 264,2728 & 88,09095 & 79,93975 & \\
\hline & 26 & 3 & 259,2344 & 86,41148 & 131,4347 & \\
\hline & 29 & 3 & 280,7149 & 93,57164 & 35,23474 & \\
\hline & 33 & 3 & 284,7411 & 94,91371 & 25,25057 & \\
\hline & 36 & 3 & 299,4087 & 99,8029 & 0,060523 & \\
\hline & 40 & 3 & 300 & 100 & 0 & \\
\hline & 46 & 3 & 300 & 100 & 0 & \\
\hline & 49 & 3 & 300 & 100 & 0 & \\
\hline & 53 & 3 & 296,9658 & 98,9886 & 2,374297 & \\
\hline & 57 & 3 & 284,2041 & 94,73471 & 0,016955 & \\
\hline & 68 & 3 & 292,8499 & 97,61664 & 0,615682 & \\
\hline Q2 & & 14 & 1323,87 & 94,56211 & 40,14495 & \\
\hline Q3 & & 14 & 1306,076 & 93,29118 & 52,60948 & \\
\hline Q1 & & 14 & 1386,082 & 99,00588 & 2,311121 & \\
\hline \multicolumn{7}{|l|}{ ANOVA } \\
\hline Fonte da variação & & $\mathrm{SQ}$ & $\mathrm{gl}$ & MQ & $\mathrm{F}$ & valor-P $\quad$ F crítico \\
\hline Linhas & & 780,3535 & 13 & 60,02719 & 3,42637 & $0,0036432,119166$ \\
\hline Colunas & & 252,0948 & 2 & 126,0474 & 7,194824 & $0,003259 \quad 3,369016$ \\
\hline Erro & & 455,4987 & 26 & 17,51918 & & \\
\hline Total & & 1487,947 & 41 & & & \\
\hline
\end{tabular}

